University of Louisville

ThinkIR: The University of Louisville's Institutional Repository

$12-2019$

\title{
A case study of teachers in an innovative professional collaborative and the evolution of their curricular conceptions, practices, and agency.
}

Alysse Christine Jacobs

University of Louisville

Follow this and additional works at: https://ir.library.louisville.edu/etd

Part of the Curriculum and Instruction Commons

\section{Recommended Citation}

Jacobs, Alysse Christine, "A case study of teachers in an innovative professional collaborative and the evolution of their curricular conceptions, practices, and agency." (2019). Electronic Theses and Dissertations. Paper 3337.

https://doi.org/10.18297/etd/3337

This Doctoral Dissertation is brought to you for free and open access by ThinkIR: The University of Louisville's Institutional Repository. It has been accepted for inclusion in Electronic Theses and Dissertations by an authorized administrator of ThinkIR: The University of Louisville's Institutional Repository. This title appears here courtesy of the author, who has retained all other copyrights. For more information, please contact thinkir@louisville.edu. 


\title{
A CASE STUDY OF TEACHERS IN AN INNOVATIVE PROFESSIONAL COLLABORATIVE AND THE EVOLUTION OF THEIR CURRICULAR CONCEPTIONS, PRACTICES, AND AGENCY
}

\author{
By
}

Alysse Christine Jacobs

B.A., West Virginia University, 2011

M.A., Spalding University, 2015

A Dissertation

Submitted to the Graduate Faculty of the College of Education and Human Development of the University of Louisville

in Partial Fulfillment of the Requirements

for the Degree of

Doctor of Philosophy

in Curriculum and Instruction

Department of Middle and Secondary Education

University of Louisville

Louisville, Kentucky

December 2019 
Copyright 2019 by Alysse Christine Jacobs

All rights reserved 

A CASE STUDY OF TEACHERS IN AN INNOVATIVE PROFESSIONAL COLLABORATIVE AND THE EVOLUTION OF THEIR CURRICULAR CONCEPTIONS, PRACTICES, AND AGENCY

By

Alysse Christine Jacobs

B.A., West Virginia University, 2011

M.A., Spalding University, 2015

A Dissertation Approved on

November 6, 2019

by the following Dissertation Committee:

\begin{tabular}{|c|}
\hline $\begin{array}{l}\text { Dissertation Director } \\
\text { Dr. James S. Chisholm }\end{array}$ \\
\hline $\begin{array}{l}\text { Committee Member } \\
\text { Dr. Lori A. Norton-Meier }\end{array}$ \\
\hline $\begin{array}{l}\text { Committee Member } \\
\text { Dr. Ann E. Larson }\end{array}$ \\
\hline $\begin{array}{l}\text { Committee Member } \\
\text { Dr. Bruce M. Horner }\end{array}$ \\
\hline
\end{tabular}




\section{DEDICATION}

This dissertation is dedicated to my parents, who instilled in me a love for teaching and learning,

and

Adam, my boy and my very best friend. 


\section{ACKNOWLEDGEMENTS}

I would like to thank all of those who helped to facilitate this journey and who came alongside of me in various ways during the past four years.

First, I would like to thank the faculty members from the University of Louisville who served on my committee. I am extremely grateful to my advisor, Dr. James Chisholm, who has invested a great deal of time in my dissertation and my thinking, working even during his sabbatical to give excellent feedback and to discuss possibilities with interest and enthusiasm. His influence on me as a teacher, scholar, and mentor has been great.

I would also like to thank the other members of my committee, Dr. Lori NortonMeier, Dr. Ann Larson, and Dr. Bruce Horner, who have introduced me to great literature, facilitated stimulating discussions, and explored with me potential directions for my research. They have shaped my teaching and inquiry in a lasting way. Additionally, I would like to express my gratitude for Dr. Elizabeth Patton, who has been a mentor and friend to me.

I am thankful for my lovely parents, who have encouraged me throughout the past several years, my four siblings, and my fantastic in-laws; all of these have put up with my incessant research and typing on family vacations for a long time.

Finally, I am completely indebted to my dear husband, Adam, who has loved me so well by taking on more work at home, convincing me to take 'brain breaks' once in a while, and sharing with me the sweet little moments that are to be found in the daily grind of life. Walking with him is a joy and a privilege. 


\begin{abstract}
A CASE STUDY OF TEACHERS IN AN INNOVATIVE PROFESSIONAL COLLABORATIVE AND THE EVOLUTION OF THEIR CURRICULAR CONCEPTIONS, PRACTICES, AND AGENCY

Alysse C. Jacobs
\end{abstract}

November 6, 2019

In this study, I explore the curricular conceptions and practices of seven diverse secondary teachers in an urban, public school district who were involved in a year-long innovative professional collaborative. I also examine the types of ecological influences, including the influence of the collaborative, that played a role in the development of their sense of agency, or lack thereof, focusing especially on their exercise of structurally transformative, or innovative, agency.

I examine the following questions in this study:

1. How do teachers perceive curriculum and their roles in curriculum? In what ways do they perceive their curricular conceptions and practices to be influenced by:
a. their past teaching experience?
b. their teacher education program?
c. their perceived professional space in the workplace (culturally, structurally, and materially)?
d. their short-term and long-term objectives for their students? 
2. How do teachers view their participation in the innovative professional collaborative as contributive to their conceptualizations about and relationship with curriculum:
a. with regard to their beliefs?
b. with regard to their written plans?
c. with regard to their classroom practice?

Approaching the 'contact zone' of the collaborative through the lens of Bakhtin's (1981) theory of dialogic thinking, and with an ecological understanding of agency informed by his concepts of ideological becoming and internally persuasive discourses, I utilized qualitative case study methods, as well as life history interview methods, to answer my research questions, garnering teachers' perspectives by way of surveys, interviews, video diaries, and innovative artifacts. I analyzed the data through processes of open and focused coding, coding using pre-established codes, and cross-case analysis.

Results from this study suggest that teachers' exercise of structurally transformative agency is impacted by the ecological influences of their past experiences, present contexts, and future goals, but that it is also — and to an even greater degree-highly influenced by their core perspectives toward these influences, regardless of whether the influences are supportive or constrictive in nature. This research also suggests that teacher preparation programs, schools, and teachers may benefit from cultivating spaces and relationships that encourage vulnerability, the production of new knowledge, trust for teachers, organic teacher leadership opportunities, reflective conversations, and occasions on which teachers can "get outside of the profession," all of which promote teacher innovation and growth in structurally transformative agency. 


\section{TABLE OF CONTENTS}

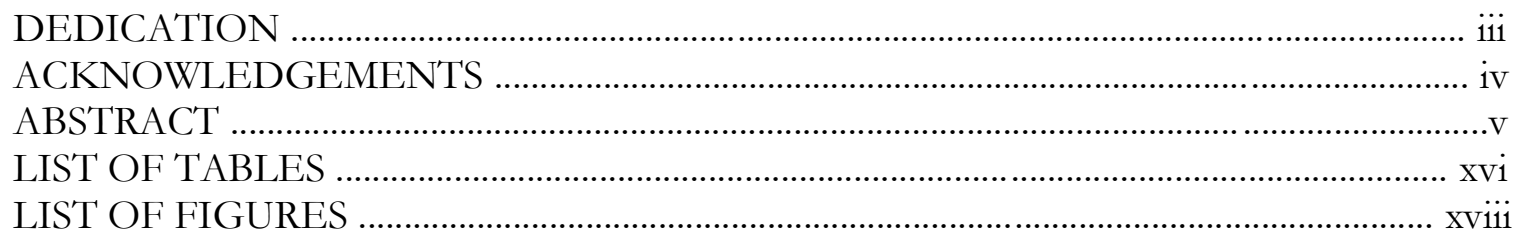

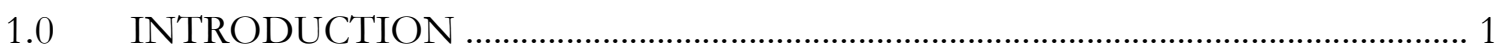

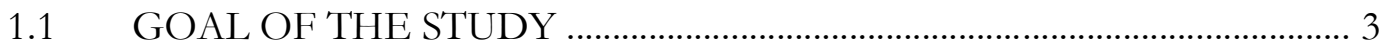

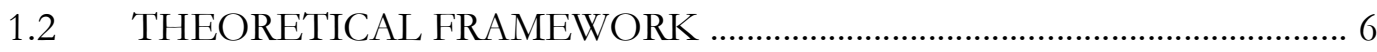

1.2.1 Ideological becoming and the contact zone ...................................... 6

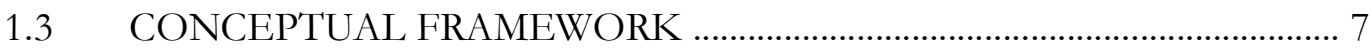

1.3.1 Teacher agency as the ecological alignment of belief and practice .... 7

1.3.2 Curriculum as lived classroom experience ......................................... 9

1.3.3 Curriculum making as dialogic design ............................................. 10

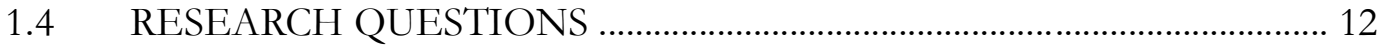

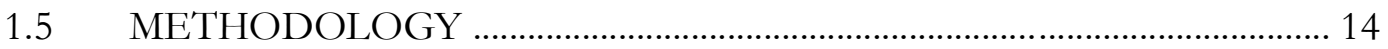

1.5.1 Methodological rationale …................................................................ 14

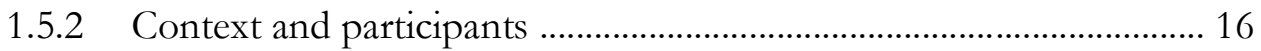

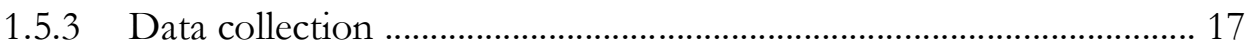

1.5.4 Data analysis and interpretation ..................................................... 18

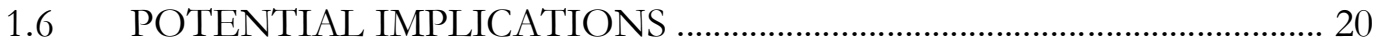

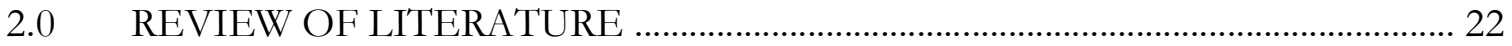




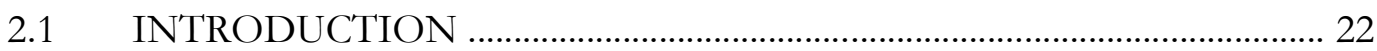

2.2 CORE CHARACTERISTICS OF TEACHER AGENCY ........................... 25

2.2.1 Teacher agency as transformative ................................................... 25

2.2.2 Teacher agency as ecological ........................................................... 26

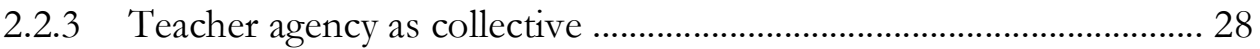

2.2.4 Teacher agency as emergent ............................................................ 29

2.3 INFLUENCES ON TEACHER AGENCY …............................................ 30

2.3.1 The past, the future, and teacher agency ........................................... 31

2.3.2 Perceived professional spaces and teacher agency …........................ 32

2.3.3 Curriculum making and teacher agency ............................................ 35

2.3.4 Teacher identity and teacher agency ….............................................. 37

2.4 CHALLENGES TO RESEARCHERS ......................................................... 39

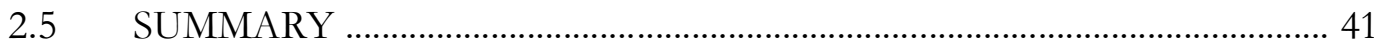

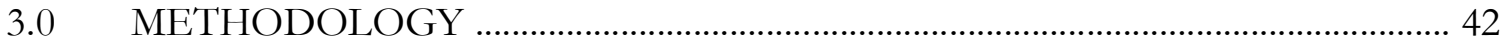

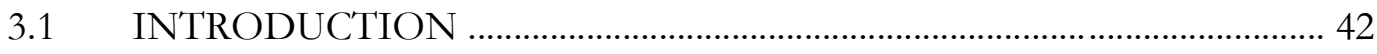

3.1.1 Methodological rationale .................................................................. 43

3.2 CONTEXT AND PARTICIPANTS …..................................................... 45

3.2.1 The innovative professional collaborative .......................................... 45

3.2.2 Selection of participants ................................................................... 50

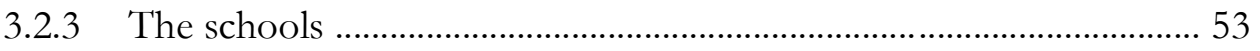

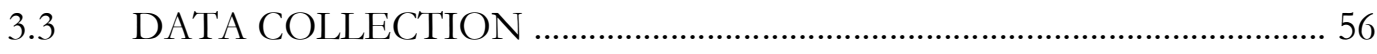

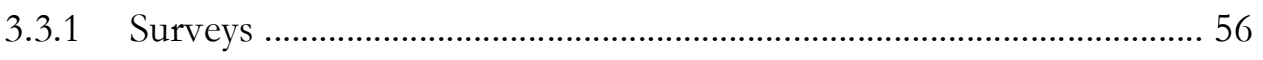

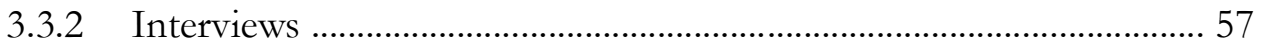

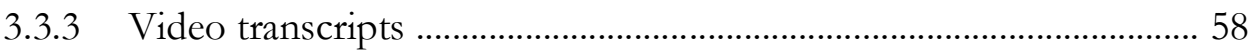




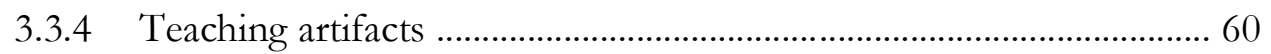

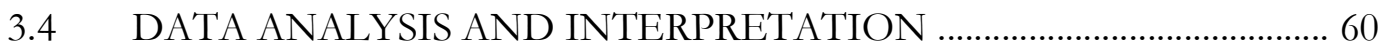

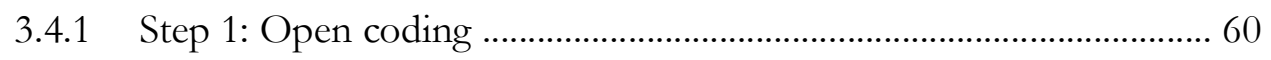

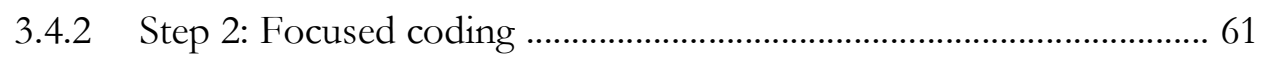

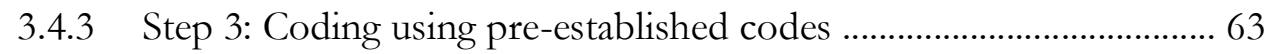

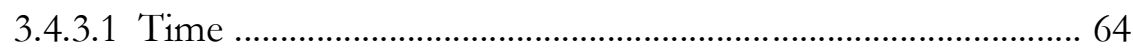

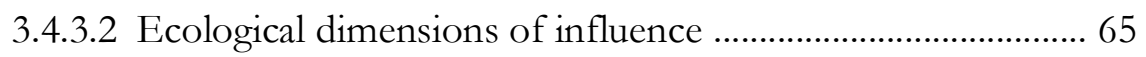

3.4.3.3 Alignment or misalignment of conceptions and practices .. 68

3.4.3.4 Structurally transformative or structurally reproductive

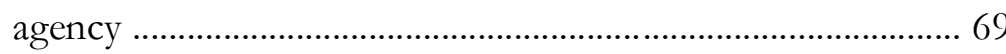

3.4.4 Step 4: Cross-case analysis ............................................................... 73

3.4.5 Establishing trustworthiness …..................................................... 74

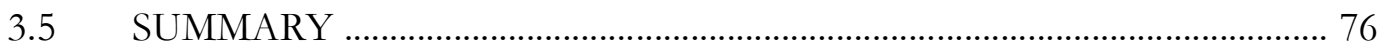

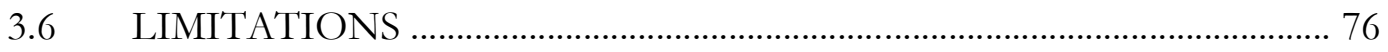

4.0 THE TEACHERS AND THEIR CONCEPTIONS AND PRACTICES .............. 79

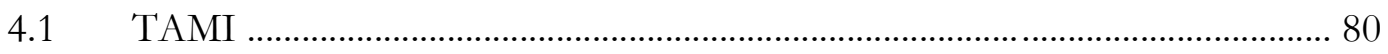

4.1.1 Tami's curricular conceptions and practices before the collaborative 82

4.1.2 Tami's curricular conceptions and practices during and after

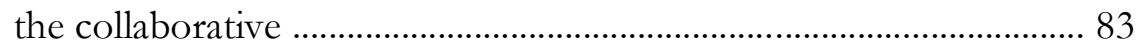

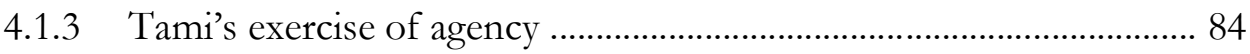

4.1.4 Artifactual evidence of Tami's agency ................................................ 86

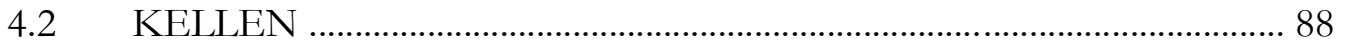

4.2.1 Kellen's curricular conceptions and practices before the 
collaborative

4.2.2 Kellen's curricular conceptions and practices during and after the

collaborative

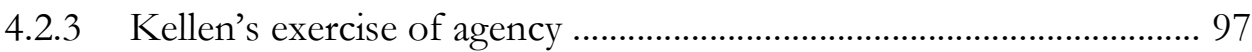

4.2.4 Artifactual evidence of Kellen's agency ............................................... 98

4.3 WALT 101

4.3.1 Walt's curricular conceptions and practices before the collaborative 102

4.3.2 Walt's curricular conceptions and practices during and after the collaborative

4.3.3 Walt's exercise of agency ..... 108

4.4 ROBERT

4.4.1 Robert's curricular conceptions and practices throughout his career

4.4.2 Robert's curricular conceptions and practices during the enactment of his instructional design 116

4.4.3 Robert's exercise of agency

4.4.3.1 Alignment and misalignment of conception and practice early in Robert's career

4.4.3.2 Alignment and misalignment of conception and practice throughout Robert's career

4.4.3.3 Alignment and misalignment of conception and practice during the enactment of Robert's instructional design ...... 121

4.4.4 Artifactual evidence of Robert's agency 122 
4.5.1 Sydney's curricular conceptions and practices before the collaborative

4.5.2 Sydney's curricular conceptions and practices during and after the collaborative

4.5.3 Sydney's exercise of agency

4.5.4 Artifactual evidence of Sydney's agency

4.6 HANNAH 135

4.6.1 Hannah's curricular conceptions throughout her career 137

4.6.2 Hannah's curricular practices throughout her career 138

4.6.3 Hannah's conceptions and practices regarding teacher professional development 138

4.6.4 Hannah's exercise of agency …...................................................... 142

4.6.5 Artifactual evidence of Hannah's agency ......................................... 146

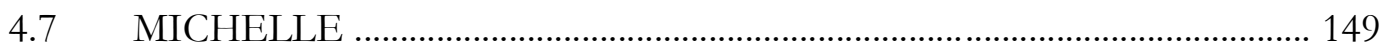

4.7.1 Michelle's curricular conceptions throughout her career ................ 151

4.7.2 Michelle’s curricular practices throughout her career ...................... 152

4.7.3 Michelle's exercise of agency .......................................................... 155

4.7.4 Artifactual evidence of Michelle's agency ...................................... 159

4.8 SUMMARY OF TEACHER PARTICIPANTS' AGENCY ….................. 161

5.0 INFLUENCES ON TEACHERS PARTICIPANTS' STRUCTURALLY

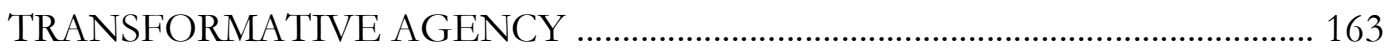

5.1 INFLUENCES THAT SUPPORTED TEACHERS' STRUCTURALLY TRANSFORMATIVE AGENCY 
5.1.1 Iterational influences: Past teaching experience

5.1.2 Iterational influences: Past teacher education 172

5.1.3 Practical-evaluative influences: Current curricular allowances, expectations, or mandates ................................................................ 173

5.1.4 Practical-evaluative influences: Current administration ................... 175

5.1.5 Practical-evaluative influences: Current coworkers ........................ 178

5.1.6 Practical-evaluative influences: Current students ........................... 180

5.1.7 Projective influences: Goals for students ......................................... 182

5.1.8 The influence of personal and professional identity ....................... 186

5.1.9 The influence of the collaborative ................................................. 188

5.1.9.1 The influence of the collaborative on Tami ......................... 188

5.1.9.2 The influence of the collaborative on Kellen ...................... 190

5.1.9.3 The influence of the collaborative on Walt ......................... 191

5.1.9.4 The influence of the collaborative on Sydney ..................... 193

5.1.9.5 The influence of the collaborative on Hannah ..................... 194

5.1.9.6 The influence of the collaborative on Robert ..................... 195

5.1.9.7 The influence of the collaborative on Michelle .................... 198

\subsection{INFLUENCES THAT THREATENED TO CONSTRAIN TEACHERS'}

STRUCTURALLY TRANSFORMATIVE AGENCY, BUT DID

NOT 199

5.2.1 Iterational influences: Past teaching experience ................................ 200

5.2.2 Iterational influences: Past teacher education .................................... 201

5.2.3 Practical-evaluative influences: Current coworkers ........................... 201

5.2.4 Practical-evaluative influences: Current students ............................ 203 
5.2.5 The influence of personal and professional identity 205

5.3 INFLUENCES THAT CONSTRAINED TEACHERS' STRUCTURALLY

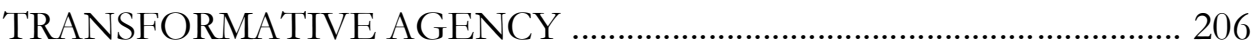

5.3.1 Iterational influences: Past teaching experience ............................. 207

5.3.2 Iterational influences: Past teacher education .................................. 208

5.3.3 Practical-evaluative influences: Current curricular allowances,

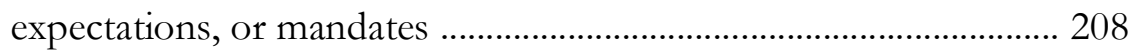

5.3.4 Practical-evaluative influences: Current coworkers ......................... 210

5.3.5 Practical-evaluative influences: Current students ............................. 211

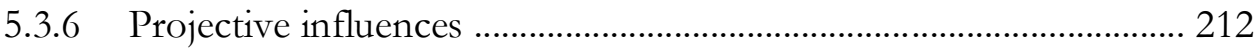

5.3.7 The influence of personal and professional identity ....................... 213

5.3.8 The influence of the collaborative ...................................................... 214

5.4 INFLUENCES THAT COULD HAVE SUPPORTED TEACHERS'

STRUCTURALLY TRANSFORMATIVE AGENCY, BUT DID

NOT 214

5.4.1 Iterational influences: Past teaching experience ................................ 215

5.4.2 Iterational influences: Past teacher education ................................. 215

5.4.3 Practical-evaluative influences: Current curricular allowances, expectations, or mandates and current administration ..................... 216

5.4.4 Practical-evaluative influences: Current coworkers ......................... 217

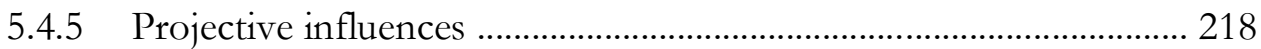

5.4.6 The influence of personal and professional identity ...................... 218

5.4.7 The influence of the collaborative ....................................................... 219

5.5 SUMMARY OF INFLUENCES ON TEACHERS' STRUCTURALLY 
TRANSFORMATIVE AGENCY

6.0 DISCUSSION AND CONCLUSION 223

6.1 CATEGORIES OF INFLUENCE ON TEACHER AGENCY .............. 223

6.1.1 Past teacher education and teaching experience ............................ 225

6.1.2 Perceived professional spaces ......................................................... 228

6.1.3 Students and goals for students ..................................................... 231

6.1.4 Personal and professional identity ............................................... 233

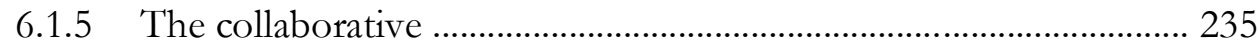

6.2 CONCEPTUALIZING STRUCTURALLY TRANSFORMATIVE

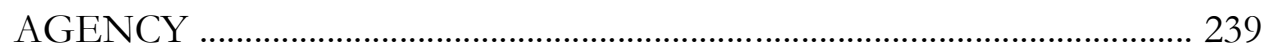

6.3 IMPLICATIONS FOR TEACHER EDUCATION, DISTRICTS,

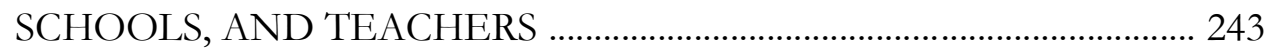

6.3.1 Implications for teacher education ............................................. 243

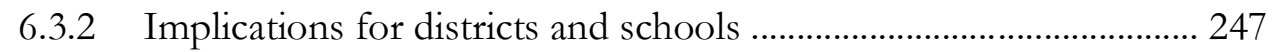

6.3.2.1 Develop trust for teachers ................................................... 248

6.3.2.2 Put innovative teachers in positions of leadership ............. 249

6.3.2.3 Encourage teachers to 'get outside of the profession' ....... 251

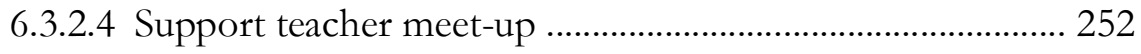

6.3.3 Implications for teachers ............................................................ 254

6.4 IMPLICATIONS FOR FUTURE RESEARCH ………………............... 256

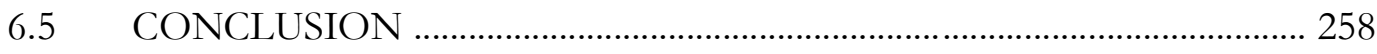

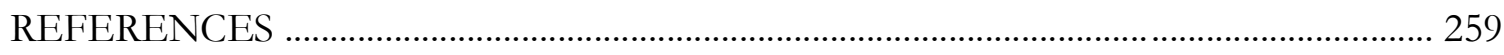

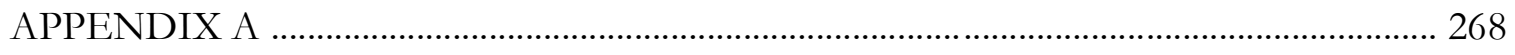

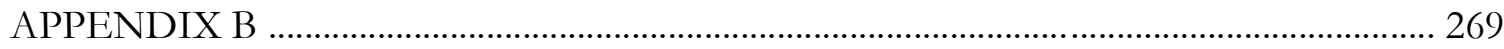


APPENDIX C

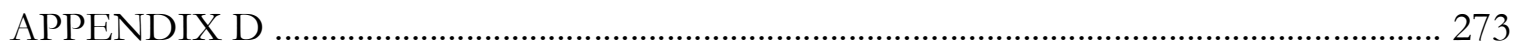

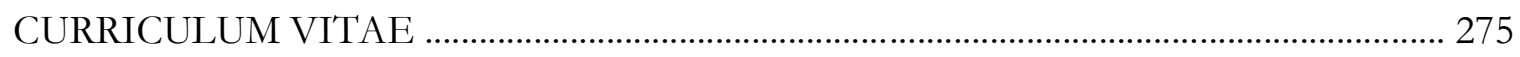




\section{LIST OF TABLES}

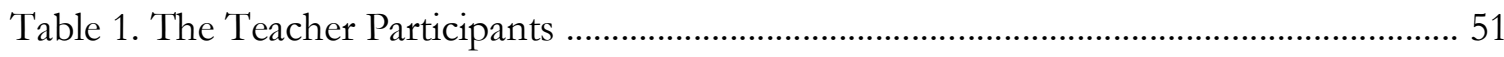

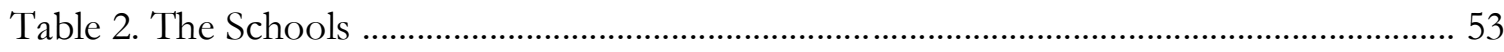

Table 3. Research Questions with Corresponding Data Sources and Analytic Tools .......... 59

Table 4. Tami's Conceptions and Practices Before and During/After the Collaborative .... 81

Table 5. Tami’s Aligned and Misaligned Conceptions and Practices Before and

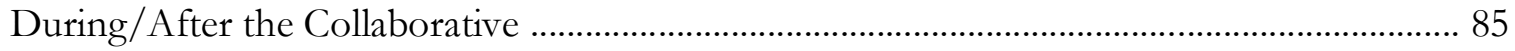

Table 6. Kellen's Conceptions and Practices Before and During/After the Collaborative .. 90

Table 7. Kellen’s Consistent Conceptions Throughout Her Career ........................................ 94

Table 8. Kellen's Aligned and Misaligned Conceptions and Practices Before and

During/After the Collaborative.

Table 9. Walt's Conceptions and Practices Before and During/After the Collaborative ... 102

Table 10. Walt's Aligned and Misaligned Conceptions and Practices Before and During/After the Collaborative

Table 11. Robert's Conceptions and Practices Early in His Career, Throughout His Career, and During the Enactment of His Instructional Design

Table 12. Robert's Aligned and Misaligned Conceptions and Practices Before the Collaborative, Throughout His Teaching Career, and During the Enactment of His Instructional Design

Table 13. Sydney's Conceptions and Practices Before and During/After the

Collaborative

Table 14. Sydney's Aligned and Misaligned Conceptions and Practices Before and During/After the Collaborative

Table 15. Hannah's Conceptions and Practices Early in Her Career, Later in Her Career, and During/After the Collaborative 
Table 16. Hannah's Aligned and Misaligned Conceptions and Practices Early in Her

Table 17. Michelle's Conceptions and Practices Early in Her Career, Throughout Her

Career, and During the Enactment of Her Innovative Design

Table 18. Michelle's Aligned and Misaligned Conceptions and Practices Early in Her Teaching Career, Throughout Her Teaching Career, and During the Enactment of Her Instructional Design 156

Table 19. Summary of the Teacher Participants' Exercise of Agency .................................... 161

Table 20. Number of Code Applications Per Participant: Influences on Curricular

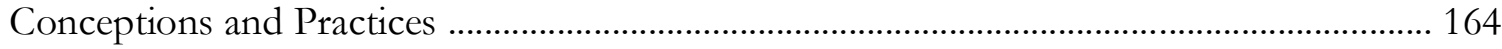

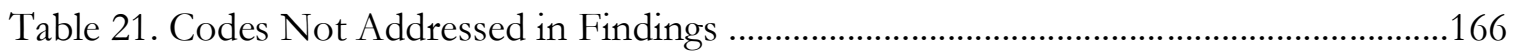

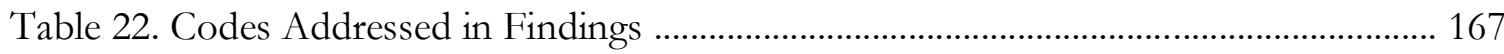

Table 23. Supportive and Constrictive Influences on Teacher Participants' Structurally

Transformative Agency 168

Table 24. Influences that Supported Teacher Participants' Structurally Transformative Agency

Table 25. Influences that Threatened to Constrain Teacher Participants' Structurally

Transformative Agency, But Did Not

Table 26. Influences that Constrained Teacher Participants' Structurally Transformative

Agency 206

Table 27. Influences that Could Have Supported Teacher Participants' Structurally

Transformative Agency, But Did Not

Table 28. (Potentially) Supportive and (Potentially) Constrictive Influences on the Teacher Participants' Exercise of Structurally Transformative Agency 220 


\section{LIST OF FIGURES}

Figure 1. The Core Components of Curriculum Making ........................................................ 11

Figure 2. The Ecological Expression of Agency Through Participation in the

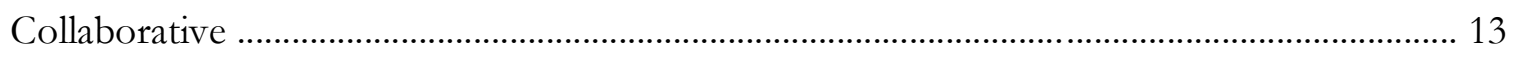

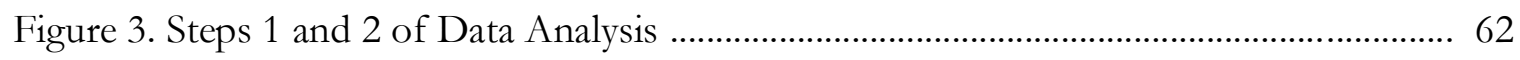

Figure 4. Coding Scheme: Influences on Teachers' Conceptions and Practices .................... 67

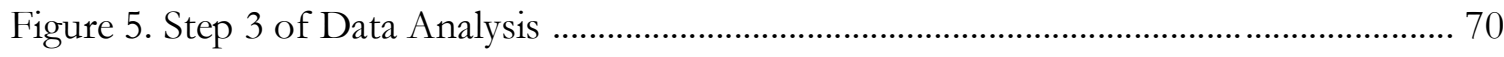

Figure 6. Influences and Teacher Agency Before and During/After the Collaborative

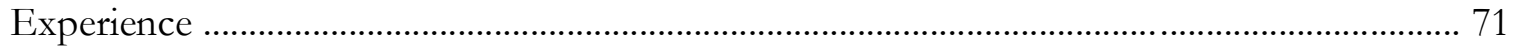

Figure 7. Coding Scheme Used for Steps 1-3 of Analysis ....................................................... 72

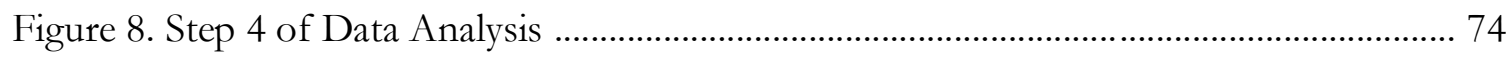

Figure 9. Hannah's Plans for the Pathways Program ............................................................ 148

Figure 10. Attributes of and Influences on Teachers Who Exercised Structurally

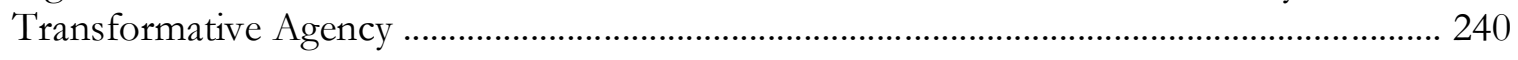

Figure 11. Attributes of and Influences on Teachers Who Did Not Exercise Structurally

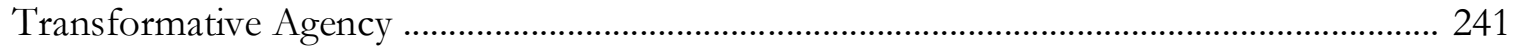




\subsection{INTRODUCTION}

Kellen and Michelle, two participants in this study, are both science teachers in the same district, have both earned master's degrees, and have both taught for many years and in various contexts, having experienced careers in homogeneously white, rural schools before working in the urban district where they are currently employed. However, this is where the similarities between them seem to end.

Kellen teaches high school Environmental Science, Biology, and Anatomy at Applewood High School. Her instructional practices have shifted greatly throughout her

career. As a new teacher, she valued teacher freedom and innovation, hands-on learning, and student-led instruction, but felt unable to enact these beliefs in her practice. Instead, she used prepackaged curriculum, followed other teachers' lesson plans, and employed direct instruction as her principal teaching method. She noted in an interview that she "felt like... a really bad teacher" and "didn't know what [she] was doing” during this time. Now, she has many of the same values that she used to, also emphasizing student engagement, student voice, and human-centered instructional design that meets both students' and teachers' needs. However, unlike in her early career, Kellen has also been able, during the past several years, to carry out instruction that aligns with these beliefs and values, resisting and challenging dominant institutional discourses and demands as she innovates through her teaching. 
Instead of following the prepackaged curriculum, Kellen designs the instruction for her courses, adhering to the state standards, but utilizing problem- and place-based curriculum as the foundation for her teaching. Kellen and her students regularly work with community professionals, spend time in the high school's on-campus forest, apply for grants together in order to solve problems in the community, and present at summits and expositions. Kellen uses the term 'go rogue' to describe the way in which she deviates from scripted curriculum as soon as possible upon being given a new class to teach. She has seen herself move from being "the giver of knowledge to a facilitator" in her practice, and has no desire to go back to using direct instruction or prepackaged curriculum, which she feels are inauthentic and often unhelpful to students. Kellen has experienced her fair share of opposition from department members regarding her decisions to design her own curriculum, but this has not hindered her innovation nor her insistence upon doing what she believes is best for her students.

Michelle teaches eighth grade science at Norton Middle School, and feels that "[her] curriculum is set by the district." Michelle reportedly believes that this curriculum is "horrible" and involves "no student engagement," regularly telling her students to "hang with [her]." "I will make this as interesting as I can," she tells them, "but it's gonna bore ya." Michelle believes that she should be designing curriculum instead of using the district curriculum. Nevertheless, she shared that she had not written a lesson plan in years, and that even if she wanted to innovate, she could not, due to the way in which the district sends science materials to teachers only at certain times during the year. Michelle even noted that her principal and assistant principal would find a way to support her in classroom innovation if she so desired, and that they were willing to do everything in their power to help facilitate 
her curricular design. Still, Michelle has chosen not to innovate in her classroom, noting that neither her curricular beliefs nor her practices have changed throughout her career.

How is it possible that two science teachers from the same district could have such drastically different perspectives on the prepackaged district curriculum and on their power to adapt, challenge, or resist it? How is it that Kellen has overcome social obstacles in her department in order to exercise agency, while Michelle has been only encouraged by the people in her school to innovate, and still chooses not to? What influences have made a difference in the way that Kellen is able to enact in her classroom that which is compatible with her beliefs, values, and convictions, while Michelle feels stuck, and completely beholden to the district mandates and status quo structures? These are the types of questions that I seek to answer through this study.

\subsection{GOAL OF THE STUDY}

In this study, I explore the types of experiences and developmental processes through which teachers journeyed in order to express agency, specifically, structurally transformative agency, which promotes innovation or the creation of new structures, as opposed to the reproduction of existing ones. Teachers face many challenges to their exercise of structurally transformative agency, such as prescriptive curricula (Meyer \& Rowan, 2006; Spring, 2015); outcomes-driven methods (Biesta, 2004; Tarnoczki, 2006); strict teacher and student accountability systems that allow for little to no instructional innovation (Apple, 2009; Harste \& Short, 2010; Schmidt \& Whitmore, 2010); largely ineffective professional development programs (Ball \& Cohen, 1999; Borko, 2004; Putnam \& Borko, 
1997); and constraining professional spaces (Oolbekkink-Marchand, Hadar, Smith, Helleve, \& Ulvik, 2017). Teacher agency is influenced, but not dictated by these difficulties, and some teachers are able to overcome environmental constraints, mobilizing their own beliefs, values and convictions in the enactment of their instruction. I seek to understand what types of contexts and processes may allow for teacher growth in agency, as agency has been shown to benefit teachers' development of strong pedagogical practice (Priestley, Minty, \& Eager, 2014); their enactment of new learning standards (Martinie, Kim, \& Abernathy, 2016; Pyhältö, Pietarinen, \& Soini, 2014); and their discernment of policies (Nguyen \& Bui, 2016); as well as increase student agency (Rivera Maulucci, Brotman, \& Sprague Fain, 2015). In order to study the evolution of teachers' exercise of agency, I examined the perceptions of teachers in an innovative professional learning collaborative, focusing on curriculum and teachers' roles in curriculum, and how teachers' curricular conceptions, practices, and agency were impacted by various influences, including the collaborative itself. The ecological model of teacher agency suggests that teachers' achievement of agency is dependent upon the iterational, practical-evaluative, and projective dimensions of one's experience, which embody past, present, and future-oriented contexts and objectives (Priestley, Biesta, \& Robinson, 2013). I sought to understand how these dimensions of experience, as perceived in teachers' past teaching experiences, teacher education programs, professional spaces, and short- and long-term objectives for their students, impacted their agency. Additionally, I examined the ways in which teachers perceived their participation in an innovative professional collaborative, which functioned as a nexus or contact zone for the

\footnotetext{
1 While the collaborative, itself, is an innovative undertaking in many ways, I frame the collaborative as 'innovative' because of its goal: that the teachers involved in it would come up with innovative approaches to issues that existed in their classroom or school.
} 
ecological dimensions of their agency, as contributing to their conceptualizations about and relationship with curriculum.

Through this study, I aim to contribute to existing educational research by comprehensively examining the influences on teachers' curricular beliefs and roles, both throughout their careers and in relation to the context of the collaborative. The teachers involved in the study had diverse perspectives, taught in different content areas, were in various career stages and school settings, and had distinct experiences in their initial teacher education programs, thus allowing me to explore the impacts of various influences on teachers' agency across career stages, school settings, and content areas, while most other studies have focused on teachers from one school or content area. This study also contributes to the literature with its consideration for the many ecological influences, past, present and future that mediated teachers' agency, its focus on the context of an innovative professional collaborative, and its emphasis on not only the influences that supported or constrained teachers' agency, but also those influences that had the potential to do so.

The findings of this study function both to support and call into question what previous research has revealed regarding influences on teacher agency. The importance of perceived professional spaces for growth in agency, and the helpfulness of certain kinds of professional development, teacher education, and goal-setting practices were supported by the findings. The findings also brought about new discovery of meaning regarding the core attributes of and ecological influences on teachers who exercise structurally transformative agency, which may be useful to inform curriculum policy and practice, professional development within schools, districts, and teacher education, and future studies. Ultimately, insights from this study may promote the development of teacher agency through its examination of those contact zones that help to promote alignment among one's beliefs, 
values, convictions, and classroom practices, and by suggesting steps to take in order to cultivate these contact zones in various educational contexts.

\subsection{THEORETICAL FRAMEWORK}

\subsubsection{Ideological becoming and the contact zone}

Bakhtin's (1981) theory of dialogic thinking, along with his concepts of ideological becoming, contact zones, and internally persuasive discourses, are central to the theoretical framework of this study. From the perspective of dialogic thinking, people pull continuously from their complex social experiences in order to make sense of and participate in their lives and, in the case of educators, their teaching and learning (Bakhtin, 1981). Ideological becoming is what Bakhtin calls the process through which this sense-making occurs. It is "how we develop our way of viewing the world, our system of ideas, what Bakhtin calls an ideological self' (Freedman \& Ball, 2004, p. 5). Bakhtin (1981) argues that 'contact zones,' in which we interact with multiple discourses and we "struggle against various kinds and degrees of authority" (p. 345), are essential to this process of ideological becoming. It is in rich and complex contact zones that we develop 'internally persuasive discourses,' or those ideologies that we come to call our own. However, these discourses are not static; Bakhtin (1981) writes, "The semantic structure of an internally persuasive discourse is not finite, it is

open; in each of the new contexts that dialogize it, this discourse is able to reveal ever newer ways to mean" (p. 346).

In this study, I understand the innovative professional collaborative to be a nexus or contact zone in which teachers' varied discourses, influenced by their past experiences, 
present contexts, and future objectives, were exposed and brought to bear on one another as teachers worked through the various steps involved in their participation. In the collaborative, teachers were led to reconsider learning in their classrooms and their perspectives on how schools should be, to frame problems that they saw, to brainstorm solutions, to design and implement plans for their classrooms, to reflect on results, and to share their ideas and with others. This process inevitably led teachers to draw on discourses formed through their past conceptions and experiences, and which were impacted by their current contexts and students, as well as their future objectives.

As a result of the rich contact zone provided by the collaborative, some teachers were able to integrate ideas into their discourses or reconfigure their discourses altogether, thus constructing new conceptualizations about curriculum, and experiencing ideological becoming. Teachers' changing ideologies, in some cases, also led to changes in classroom practice; if these ideologies and practices aligned with one another, agency was achieved. Whether agency was achieved or not, I sought to understand the ways in which the various dimensions of teachers' experience, bumping up against one another in the collaborative setting, and experienced outside of the context of the collaborative as well, impacted teachers' conceptions about and roles in curriculum, and ultimately, their agency.

\subsection{CONCEPTUAL FRAMEWORK}

\subsubsection{Teacher agency as the ecological alignment of belief and practice}

The nature of human agency is highly debated, as it is informed by several theoretical framings (Priestley et al., 2012). Teacher agency, more narrowly, and in much the same way, has 
various characterizations. Campbell (2012) defines teacher agency as the state of being able to enact in practice that which is compatible with one's values, beliefs, and convictions. While current beliefs and practices align in the expression of agency, the past and future contribute to teacher agency as well.

Priestley et al. (2012) note that agency is neither governed solely by a person's own beliefs and convictions, nor their social or societal contexts, defining it rather as "a matter of personal capacity to act, combined with the contingencies of the environment within which such action occurs" (p. 196). This perspective is neither overly individualistic nor societally deterministic, as outside forces influence, but do not define agents. Priestley et al. believe that agency can evolve, changing as people change, as contexts change, and as society at large changes. It is an emergent phenomenon, achieved through one's relationship to past influences, orientations toward the future, and engagement with the present: the iterational, practical-evaluative, and projective dimensions of one's life and experience (Priestley et al., 2013). It is not something one has or does not have, is or is not, but is rather something that is achieved (Priestley et al., 2016).

With these ideas in mind, I adopt a definition of teacher agency that is in keeping with Priestley et al. (2012), who argue that

the extent to which teachers are able to achieve agency varies from context to context based upon certain environmental conditions of possibility and constraint, and that an important factor in this lies in the beliefs, values and attributes that teachers mobilize in relation to particular situations. (p. 191)

While there are diverse factors that play into teacher agency, the relationships of primary interest to be explored here are those among teacher agency, curriculum innovation, and the influences that impact teachers' curricular conceptions, curricular practices, and ultimately, agency. I elaborate further on the transformative, ecological, collective, and emergent nature of teacher agency in chapter 2. 


\subsubsection{Curriculum as lived classroom experience}

The original definitions of curriculum are "the course of one's life," or "a brief account of one's career" (Clandinin \& Connelly, 1992, p. 364). These definitions are of interest, because neither of them seems to match the view of 'curriculum' that has pervaded educational research and common thought for decades: that of a set of prescribed materials and systems, which "have goals, strategies, tests, textbooks, worksheets, appropriate student response, etc. integrated together” (Apple, 2009, p. 205). Clandinin and Connelly (1992) write that "over the years...educational research has gradually sapped curriculum of its content meaning and injected in its place a 'methods' and 'forms' emphasis" (p. 364). They note that since it was introduced to the English language in the 1800s, 'curriculum' has retained a programmatic and dogmatic connotation. However, nowhere in the original definitions is there a suggestion that curriculum is separate from lived experience or instruction, or that it is comprised of mere methods and forms. Rather, curriculum is to be intimately entwined with the life of the learner, both present and future.

Dewey (2009) sees curriculum as that which helps the learner to participate in the social consciousness of humankind, and that which stimulates the child's powers by the demands of the social situations in which he finds himself [sic]. To Dewey, curriculum involves both the psychological and social sides of the child, and must be relevant to the child's own social activities and interests, thus promoting the agreeableness and continuity of experience that are so integral to learning. "The school must represent life," he writes, "life as real and vital to the child as that which he carries on in the home, in the neighborhood, or on the playground" (p. 36). Curriculum is to be relevant to students' lives and to enable them 
"to do better in life" (Eisner, 2009, p. 329). The curriculum is to be inseparable from the life of the learner.

The teacher is also a vital component in the curriculum. Agreeing with many groundbreaking education theorists such as Dewey (1902) and Schwab (1969), Clandinin and Connelly (1992) imagine the teacher "not so much as a maker of curriculum but as a part of it” (p. 365). They do not view intentions, materials, and practices as separate from curriculum, but as essential pieces of it, with the teacher as another integral part.

It is from this perspective that I define curriculum: it is not only the course plan, the materials, the teacher's intentions or instructional strategies that make up curriculum, but the complete lived experience of both teacher and students in the classroom. Curriculum is both prescriptive and descriptive; it is a set of plans used to guide school learning and the carrying out of those plans (Glatthorn, Boschee, Whitehead, \& Boschee, 2016). It is not only what is intended, but what is written, supported, assessed, taught, and lived. Therefore, in speaking of teachers as curriculum makers, or curriculum innovators, I mean that it is this crafting of the total classroom experience, with students' powers and purposes in mind.

\subsubsection{Curriculum making as dialogic design}

Those who understand curriculum as a mere course plan, made up of page numbers and assessments, often view teachers as transmitters of curriculum rather than active agents in their relationship to it. Many teachers do, in fact, take on this identity as curriculum transmitter, or one who adheres closely to a text and/or other prepackaged curriculum materials. Others choose to supplement and adapt prepackaged curriculum frameworks in order to better suit instruction to their context; these are curriculum developers. Still others 
design their own curriculum frameworks, without depending on a scripted or prepackaged curriculum as the foundation of their instruction; these are curriculum makers (Shawer, 2010).

These teachers are likely to agree with Harste and Short's (2010) perspective of curriculum as "putting a system of beliefs into action" (p. 127). Because teacher beliefs are so complex, their enactment in the classroom almost necessarily involves the adaptation or creation of instructional frameworks; however, there are certainly teachers who strive to enact curriculum as prescriptively as possible.

\section{Curriculum Making}

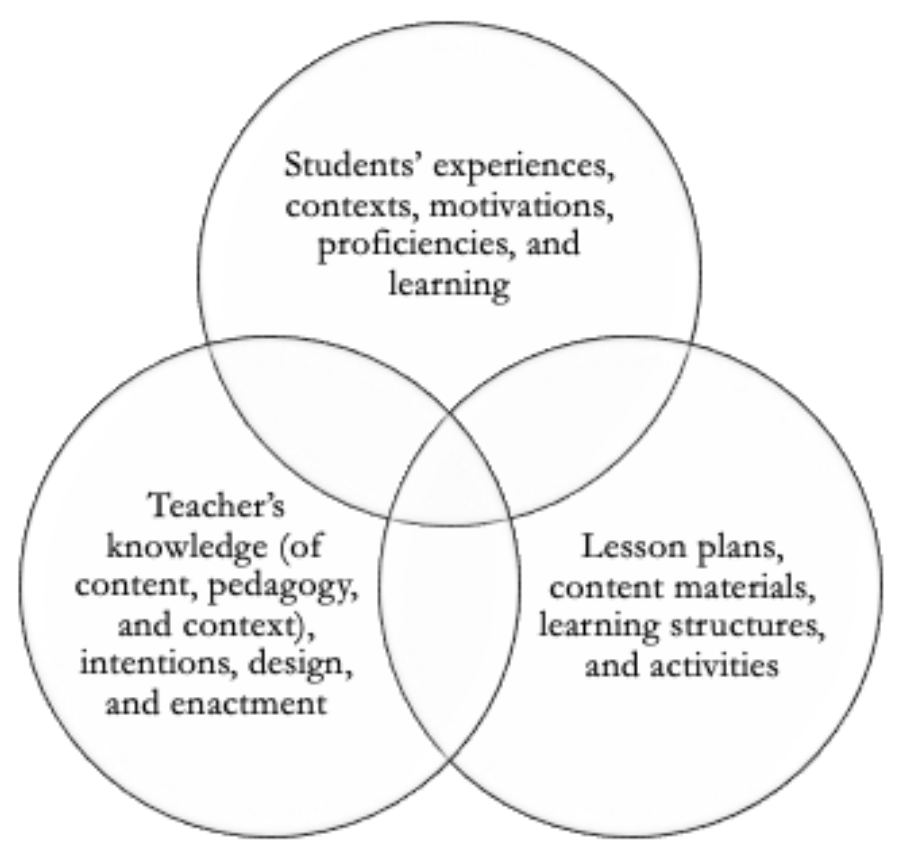

Figure 1. The Core Components of Curriculum Making

As seen in Figure 1, curriculum making does not involve merely following a course of study, but knowledge of one's content, knowledge of pedagogy, and the way content knowledge and pedagogic knowledge effectively intersect in the context of the classroom to 
facilitate students' learning (Shulman, 1986). True curriculum making entails the curriculum being both created by students and teacher and experienced by students and teacher (Shawer, 2010); it is a dialectic activity between teacher and students, requiring flexibility on the teacher's part. Contrary to the 'fidelity approach' toward curriculum, which involves teachers simply transmitting that which has been deemed the 'official curriculum' by policy makers, clarity of action in curriculum making is borne of knowing one's local context, students, and their needs. In this approach, "the problem and possible solutions constantly co-evolve" (p. 172).

\subsection{RESEARCH QUESTIONS}

In this study, I sought to understand the ecological dimensions of teachers' experiences (past, present, and future) that influenced their curricular conceptions, practices, and agency, as well as the kind of role that the innovative professional collaborative might have played in teachers' development (or lack thereof) of structurally transformative agency. Through this study, I hope to inform teachers, schools, and teacher preparation programs regarding pathways to teachers' exercise of agency, with the innovative professional collaborative being one possible pathway. The research questions guiding this study were:

1. How do teachers perceive curriculum and their roles in curriculum? In what ways do they perceive their curricular conceptions and practices to be influenced by:
a. their past teaching experience?
b. their teacher education program? 
c. their perceived professional space in the workplace (culturally, structurally, and materially)?

d. their short-term and long-term objectives for their students?

2. How do teachers view their participation in the innovative professional collaborative as contributive to their conceptualizations about and relationship with curriculum:

a. with regard to their beliefs?

b. with regard to their written plans?

c. with regard to their classroom practice?

The Ecology of Agency in Collaborative Curriculum Making

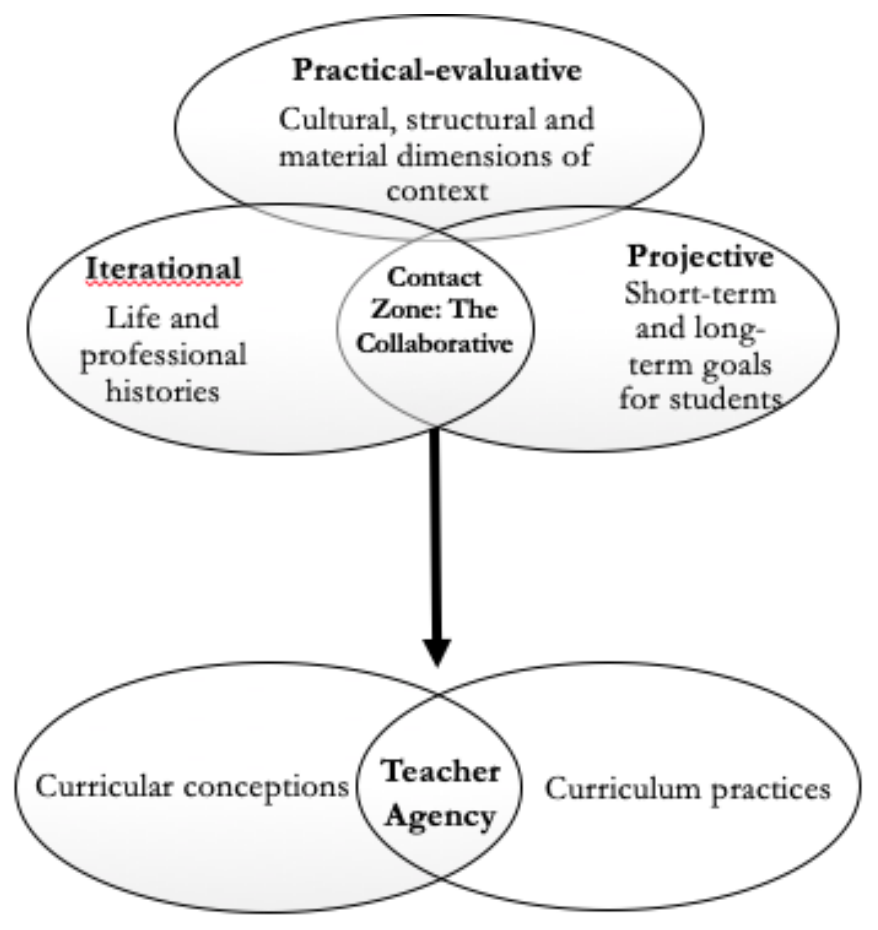

Figure 2. The Ecological Expression of Agency Through Participation in the Collaborative (Bakhtin, 1981; Campbell, 2012; Priestley et al., 2013) 
Figure 2 demonstrates the relationship between the ecological dimensions of teachers' lives and experiences (Priestley et al., 2013); the contact zone of the innovative professional collaborative where teachers' past experiences, present contexts, and future intentions interact with one another as well as the discourses of others in the collaborative (Bakhtin, 1981); and the achievement of agency through the emergent alignment of teachers' curricular conceptions and practices (Campbell, 2012). In this study, I sought to understand how teachers' perceptions of and roles in curriculum (i.e. beliefs and practices) were impacted by various past, present, and future influences on their lives. Moreover, I sought to explore how the contact zone created by the innovative professional collaborative functioned to put these ecological dimensions into more intimate relationship with one another, thus impacting teachers' curricular beliefs, classroom practices, and ultimately, their achievement of agency.

\subsection{METHODOLOGY}

\subsubsection{Methodological rationale}

I used qualitative research as the mode of inquiry for this study. The qualitative paradigm was appropriate for the following reasons: I sought to understand the meaning others construct; I was the primary instrument for data collection and analysis and had contact with participants; the selection of participants was nonrandom; I employed an inductive research strategy; and the product of the study is richly descriptive, rather than statistical (Merriam, 2007). Dyson and Genishi (2005) write, "It is the messy complexity of human experience that leads researchers to case studies in the qualitative or interpretive 
tradition" (p. 3), and indeed, the relationship among teacher agency, curriculum, and the ecological dimensions of their experience is complex.

Case study methods were suitable for this particular study for a number of reasons. Case study involves "intense study of singular individuals, local activities, and specified places" (Dyson \& Genishi, 2005, p. 1), all of which the confines of the innovative professional collaborative provided. Dyson and Genishi note that qualitative case study researchers "are interested in the meaning people make of their lives in very particular contexts" (p. 9), and the way they experience the world around them. The end goal of a qualitative case study is not merely to organize data, but to understand the phenomenon at hand through the lens of the participants in the case (Dyson \& Genishi, 2005), producing a rich, thick description that illuminates a reader's understanding "by bringing about new discovery of meaning, extending the reader's experience, or confirming what is known" (Merriam, 2007, p. 30). The context of the innovative professional collaborative was conducive to these aspects of case study research, as there were many opportunities for participants to reflect on and discuss their experiences, beliefs, and perceptions during interviews, video diaries, and surveys. Teachers' perspectives were inherent in all data sources.

Additionally, I used life history interview methods in my design of the questions in my semi-structured protocol. In this method, questions are designed to help the participant, researcher, and ultimately, the reader, to understand "how a specific human life is constructed and reconstructed in representing that life as a story" (Atkinson, 2012, p. 16). Qualitative case study methods, as well as life history interviews, allowed me to answer my research questions and are consistent with the ecological framing of teacher agency and a dialogic understanding of curriculum. 


\subsubsection{Context and participants}

Data for this study were collected from seven teachers and one lead mentor who participated in an innovative professional collaborative during the 2018-2019 school year. The collaborative ran from November to May, involving teacher mentees from five schools in a large, urban district in the southeastern United States, and mentors from various schools around the district. Teachers who desired to be innovators in their classrooms and curriculum, and to grow alongside of others, were welcomed into the collaborative as “teacher founders."

Led by their mentors, teachers tried new ideas in their classroom on both small (lesson) and large (unit) scales, as well as through schoolwide initiatives. They came together as a cohort at least seven times during the year in a pub or coffee shop to discuss their ideas and progress, to ask questions, and to help one another. The process through which they worked in order to innovate emulated the entrepreneurial design process in which preconceived notions and engrained perspectives are disrupted and reimagined; contexts are researched; problems are named; solutions are brainstormed; and plans to remedy a discovered problem are created, implemented, and reflected upon. Often, teachers built an instructional plan in response to what they discover about their previously held perspectives, their curriculum, their students, and their context, becoming curriculum makers who were driven by new and emerging internally persuasive discourses. At the end of the year, teachers took part in a Demo Day, in which they were able to share what took place in their classrooms and schools, and in their thinking throughout the year with various community partners and local education stakeholders. 


\subsubsection{Data collection}

To construct the teacher cases, or descriptions of the meaning that they made of their teaching lives, I utilized four methods of data collection: (1) surveys; (2) interviews; (3) video data; and (4) teacher artifacts. This triangulation of data served to strengthen the findings of the study (Merriam, 2007). All data sources explored teachers' perceptions of curriculum, their perceived roles in curriculum, the influences they saw as having impacted their curriculum practices, and their thinking about how their participation in the collaborative contributed to their conceptualizations about and relationship with curriculum.

After several teachers agreed to be a part of the study, used a teacher background survey to identify a smaller group of seven diverse teacher participants who participated in the remaining stages of data collection (see Appendix A). The survey questions solicited teachers' beliefs and convictions regarding teaching, learning, and curriculum, their goals for their students, and their perceptions about the alignment among their beliefs, intentions, and curriculum practices, offering information that ensured the diversity of participants in the study. Semi-structured interviews (see Appendix B) occurred once with each teacher participant during the course of the research study, and allowed for the examination of participants' past and present curricular conceptions and practices. Interviews also sought to understand, from teachers' perspectives, the personal and professional influences on their curricular conceptions and practices, including the influence of the innovative professional collaborative. The lead mentor or facilitator of the collaborative was also interviewed in order to garner her insights regarding participants' growth in agency and the influences on it (see Appendix D). Video data focused particularly on the perceived impact of the professional collaborative on teachers' curriculum beliefs and classroom practice, with 
teachers sharing their experiences in the form of individual video diaries (see Appendix C). Additionally, video data explored the influence of the collaborative on teachers' written plans, as teachers provided artifacts in the form of instructional plans and documents and shared about the relationship of their involvement in the collaborative to these artifacts. These teaching artifacts were subject to interpretation by the teacher participants who created them, but I also analyzed the plans for consistencies and inconsistencies with teachers' asserted curricular beliefs, objectives, and practices. Finally, the Demo Day at the end of the school year, in which the members of the collaborative took part, provided further video data, as participants shared designs, processes, and reflections from their experience in a public forum.

\subsubsection{Data analysis and interpretation}

Data analysis occurred simultaneously to data collection, as is typical of the qualitative research study, whose design is by nature emergent (Merriam, 2007). Inductive analysis began with the first interview and the first video diary, as this allowed me to refine the other individual interviews. As I reviewed interview and video transcripts, as well as teacher artifacts, I noted emergent themes and developed theories and hypotheses about the data by utilizing analytic memos, and I focused data collection in response, seeking continuously to understand not only the evolution of teachers' curricular conceptions, practices, and agency, but ultimately, the influences that teachers believe to have catalyzed them.

Once data collection was complete, I created virtual case binders for each teacher, and theoretically coded interview transcripts, video data, and documents using open coding, 
which allowed for "opening up avenues of inquiry" (Emerson, Fretz \& Shaw, 2011, p. 175) regarding teachers' experiences, perceptions, and practices. As I read and coded the data for each teacher, I made notes as to possible categories and patterns, and generated beginning hypotheses regarding the greatest influences on teachers' curriculum beliefs and practices (and thus, their agency) based on teachers' perceptions.

Once data collection was complete, I analyzed all of the data using pre-established codes by using the online coding application, Dedoose. These pre-established codes reflected the purpose of the research study and were rooted in the theory of agency (Campbell, 2012; Priestley et al., 2013). I analyzed units of data that were potentially meaningful as I moved between the data and the related research literature, coding and organizing data with regard to (1) time; (2) ecological dimensions of agency; and (3) alignment and misalignment of teachers' curriculum beliefs and practices.

While engaging in line-by-line open and focused coding using the preestablished codes, I simultaneously engaged in focused coding to construct emergent codes. To do this, I constantly compared data strands in each individual case and across cases (Merriam, 2007), looking for patterns. I then wrote memos detailing the patterns identified in my independent analysis, seeking to connect the patterns to theory and prior research (Emerson et al., 2011).

Finally, I used cross-case analysis (Merriam, 2007; Stake, 2006) to identify similarities and differences across the cases, and to produce theoretical insights with regard to teachers' agency and the influences on it. While the purpose of the study was not to compare the teachers to one another, it is important that "the single case is studied with attention to other cases" (Stake, 2006, p. 4). I utilized cross-case analysis to present a unified description across individual cases.

The findings of this study regarding teachers' exercise of agency are presented as 
seven individual cases in chapter 4, while the trends regarding various influences on their agency drive the organization of chapter 5. General explanations regarding the teachers' agency and the influences on their agency are suggested. Dyson and Genishi (2005) remind us that:

[t]hrough analysis we are not on the trail of singular truths, nor of overly neat stories. We are on the trail of thematic threads, meaningful events, and powerful factors that allow us entry into the multiple realities and dynamic processes that constitute the everyday drama...in educational sites. (p. 111)

They continue, "It is, in fact, the competing stories, put into dynamic relation with one another, that allow insight into participants' resources and challenges and, moreover, into the transformative possibilities of social spaces for teaching and learning” (p. 111). Though multiple insights and realities surfaced within and among cases, the end goal was to weave together "the contextual threads so that a quilt of persuasive images—a coherent narrativeemerge[d]" (p. 112). Through the various lenses of the teachers in the study, I sought to construct coherent narratives and rich descriptions about the relationship of agency to the influences they perceived to be at work in their professional lives.

\subsection{POTENTIAL IMPLICATIONS}

The findings of this study are useful to inform professional development for individual teachers and schools; teacher education programs; and future research on the impact of various types of professional development, as well as in areas such as ideological becoming, contact zones, teacher agency, and curriculum making. Discovering the types of ecological influences that are most impactful in the formation of teachers' curricular conceptions, practices, and achievement of agency is crucial, if schools and teacher education programs are to be informed and purposeful in their approach to teacher development. 
Furthermore, research indicates that teacher development and support can make the difference between teachers remaining in the profession or leaving it. The impacts of professional collaboration with other teachers and school leaders (Carver, 2004; Johnson \& Birkland, 2003; Johnson et al., 2001; Shagoury, Campbell, \& Carreker, 2007), teacher preparation programs (Darling-Hammond \& Bransford, 2005; Flores \& Day, 2006), and school setting (Grossman, Thompson, \& Valencia, 2002; Knapp \& McLaughlin, 1999; Talbert, McLaughlin, \& Rowen, 1993; Weiss, 1999) on teacher retention and self-efficacy are already well-documented (Early \& Shagoury, 2009). However, in this study, I seek to move beyond the influences of these factors on teacher retention and self-efficacy, and to describe in depth how the various ecological dimensions of teachers' lives and experiences, and their participation in the contact zone of the innovative professional collaborative lead to greater teacher agency. The necessity and the nature of teacher agency, as well as studies regarding influences on teacher agency, are expounded upon in chapter 2. 


\subsection{REVIEW OF LITERATURE}

\subsection{INTRODUCTION}

Teacher agency has historically been understood as intimately related to the absence of prescriptive curricula (Foley \& Pang, 2006), because in its stead, teachers are able to design and enact curricula that are contextually sensitive and student-based. Thus, teachers engage their own knowledge, skills, beliefs, values, and convictions in the act of curriculum making, and not merely their ability to transfer information. Still, there are many issues that keep teachers from this practice of curriculum making.

One common reason why teachers do not develop their own curriculum frameworks is the professional bind in which they exist. Priestley, Biesta, Philippou, and Robinson (2016) note that while teachers are increasingly asked to (1) be curriculum developers and (2) engage in continuous professional formation, there is also a growing emphasis on (3) "accountability systems and the use of metrics to measure educational effectiveness" (p. 3). The first two expectations put teachers at the center of the educational process, promoting a bottom-up approach, while the latter trend upholds top-down, teacher-proof curricula. These trends are incompatible, and cannot effectively coexist. Because of the tension between them, "performative cultures and instrumental decision-making by teachers are at large, but teachers are distancing themselves from their personal values in order to 'play the game"' (p. 3). This tension is not helpful to the achievement of teacher agency, which 
depends not only on teachers' capacity for agency, but also contextual conditions (Priestley et al., 2012).

Freire (1998) also calls attention to this unfortunate paradox, saying that the same "experts who overload their teaching packages with detail, even explicitly promote their materials by stating that one of the main objectives of their teaching packages... is to train prospective teachers to become critical, daring, and creative" (p. 8). He notes the vast chasm that lies between this expressed aim and teachers' actual behavior, as they are "enslaved by the packages themselves, domesticated by the teachers' guides, limited in their adventure to create” (p. 9). Schmidt and Whitmore (2010) note that teachers wrestle with the strictly imposed limits on who they can be as educators, while simultaneously carrying the identity of 'knowledgeable professionals.' The 'deskilling' of teachers is pervasive (Apple, 2009). Even when teachers try to innovate within the linear prepackaged curriculum, they often become frustrated, because their innovations do not fit within these strict frameworks (Harste \& Short, 2010). There is a dominant separation between 'curriculum' and 'teacher' in the field of education that is difficult to overcome (Clandinin \& Connelly, 1992; Craig, 2010; Kontovourski, Philippou, \& Theodorou, 2018).

In spite of the challenges posed to teacher agency by prescriptive curricula (Meyer \& Rowan, 2006; Spring, 2015); outcomes-driven methods (Biesta, 2004; Tarnoczki, 2006); constraining professional spaces (Oolbekkink-Marchand et al., 2017); and largely ineffective professional development endeavors (Ball \& Cohen, 1999; Borko, 2004; Putnam \& Borko, 1997), teacher agency is worth pursuing yet. Teacher agency has been found to play a crucial role in teachers' development of strong pedagogical practice (Priestley et al., 2014), their responsible enactment of new learning standards in the classroom (Martinie et al., 2016; Pyhältö et al., 2014), their resistance of poor policies (Nguyen \& Bui, 2016), and the opening 
up of additional avenues for curriculum innovation (Catling, 2013; Gudmundsdottir, 1991; Shawer, 2010; 2017; Priestley, Edwards, Priestley, \& Miller, 2012). Perhaps the greatest benefit of teacher agency is its promotion of student agency (Rivera Maulucci et al., 2015). Teachers need agency to navigate the shifting sands of educational policies and expectations, to realize their potential as professionals, and to create effective learning opportunities for students.

Understanding the kinds of experiences and developmental processes through which teachers journey in order to express agency is important. At a time when teachers are often asked simply to adhere to prepackaged curriculum, or on the other hand, are given no curriculum materials at all, some are still able to achieve teacher agency—the emergent ability to carry out in the classroom that which is compatible with their beliefs, values, and convictions regarding teaching and learning. How they achieve agency is the question at hand.

I begin this literature review with current scholarship on theories of agency, drawing from this body of work to articulate an understanding of the structurally transformative, ecological, collective, and emergent nature of teacher agency. Next, I offer a thematic overview of studies that have examined the influence of various factors on teachers' achievement of agency, including past experiences, future goals, perceived professional spaces, curriculum making opportunities, and identity. Though I argue that these studies are limited in scope, I build on their findings to lay the foundation for a more comprehensive examination of the influences on agentive teachers' curricular beliefs and roles within the context of a yearlong innovative professional collaborative. 


\subsection{CORE CHARACTERISTICS OF TEACHER AGENCY}

I understand teacher agency to mean the ability to mobilize in the classroom that which is compatible with one's values, beliefs, and convictions, and which is influenced by personal, social and societal factors. It is important to grasp the transformative, ecological, collective, and emergent characteristics of teacher agency to a greater extent in order to comprehend the fullness of this definition as I employ it in this study.

\subsubsection{Teacher agency as transformative}

Some view teacher agency as involving the absence of prescriptive curricula, while others understand teacher agency as the enactment of "research-tested prescriptive curricula in ways that meet state-mandated learning targets" (Golden, 2018, p. 2). Thus, it is important to distinguish between what Hays (1994) proposes as structurally reproductive and structurally transformative agency. Structurally reproductive agency is expressed by the affirmation or reproduction of existing structures, such as prescriptive curricula, whereas structurally transformative agency is achieved by innovation, or in the creation of new structures.

Chisholm, Alford, Halliday, and Cox (2019) note that in 21 studies that they reviewed and analyzed regarding teacher agency, most agentive teachers were challenging top-down mandates and responding to students' needs in their teaching (Pease-Alvarez \& Samway, 2008; Rubin \& Land, 2007; Vaughn \& Faircloth, 2011); in other instances, though, teachers exercised agency in ways that followed standardized methods and institutional mandates (Miller, Morgan, \& Medina, 2017; Smagorinsky, Wilson, \& Moore, 2011). In the

former studies, teachers expressed agency by pushing back against prescriptive curricula and 
institutional mandates - their agency was structurally transformative. In the latter studies, however, teachers who adhered to the curricular prescriptions and mandates of their various institutions exercised structurally reproductive agency as they reinforced status quo structures. Emirbayer and Mische (1998) argue that "the structural environments of action are both dynamically sustained by and also altered through human agency" (p. 964).

Structurally transformative agency is creative and critical in nature, generally leading teachers to do things such as: give students more choice, incorporate new genres, change and ignore portions of the scripted curriculum, plan opportunities for whole-school meetings for teachers to change their curriculum, and take on other responsibilities, such as mentoring other teachers and leading professional development (Chisholm et al., 2019). Wessel-Powell, Buchholz, and Brownwell (2019) describe teachers' local, personal, and creative enactments of their own values and skills as "little-p policies," as opposed to the "Big-P policies" which are formal, top-down policies as given and regulated by the government. Another way of describing teachers' structurally transformative agentive action, then, is "little-p policy making."

In this research study, I understand the type of agency that is to be sought after as structurally transformative, as I believe agency to involve the power to act autonomously of the constraints of social structures (Biesta \& Tedder, 2006) when these constraints are not in alignment with one's beliefs, convictions, and values (Archer, 2000; Campbell, 2012).

\subsubsection{Teacher agency as ecological}

Agency is indeed "a matter of personal capacity to act" (Priestley et al., 2012, p. 196), but it is also contingent in many ways on the environment within which action occurs. 
Priestley et al. (2012) believe that a teacher's capacity to achieve agency varies based on the environmental conditions of possibility and constraint in their context, as well as on the beliefs, values, and attributes that they mobilize in response to their situation. They note that agency is neither governed solely by a person's own beliefs and convictions, nor their social or societal contexts. Priestley et al.'s (2013) ecological model of teacher agency demonstrates the relationship among the iterational, practical-evaluative, and projective dimensions of teachers' experience, which inform one another and determine the extent to which a teacher can achieve agency. The iterational dimension consists of one's life and professional histories, or elements of the past; the practical-evaluative dimension involves the cultural, structural, and material elements in one's setting, or the present supports or constraints in one's context; and the projective dimension involves one's creative configurations of the trajectory of one's future.

Priestley et al. (2013) believe that in the interaction of these three dimensions, agency is realized. Campbell (2012), while in accordance with Priestley et al.'s (2013) understanding of agency, goes one step further, emphasizing that agency is not only influenced by past experiences, present context, and future orientations, but that agency is achieved by the capacity of a teacher to govern their practice in a way that aligns with their personal and professional beliefs. The alignment of belief and practice is the hallmark of teacher agency.

Agency is understood here not as less than an individual or intrinsic capacity, but certainly more: it is an ecological phenomenon, as it is shaped not only by local conditions, practices, and understandings of policies, but also by past experiences and orientations toward the future. 


\subsubsection{Teacher agency as collective}

An important characteristic of agency that is both ecologically influenced and structurally transformative is that it is collectively achieved. However, this aspect of agency is challenged by prescriptive and performative mandates, which minimize the possibility of collective goal-setting. Instead, these mandates encourage the rehearsal of so-called "agentive" moves by individual teachers that are structurally reproductive instead of transformative, and require little to no navigation (Eteläpelto, Vähäsantanen, Hökkä, \& Paloniemi, 2013; Golden, 2018; Kolman, Roegman, \& Goodwin, 2016; Ticknor, 2015).

“Opportunities for systematic sense-making” (Biesta, Priestley, \& Robinson, 2015, p. 636) are a critical part of agency, as they create spaces in which professionals can work together to evaluate practices and processes, and their impact on instruction, teachers and learners (Golden, 2018; Hökkä, Vähäsantanen, \& Mahlakaarto, 2015). An understanding of teacher agency as collective sees that it is in the rich tension of contact zones created by the interaction of multiple discourses that the status quo is able to be challenged and participants are able to develop their own ideologies (Bakhtin, 1981), leading to greater agency.

Without conditions for collaboration and collective goal-setting, Golden (2018) argues that distant experts will continue to dictate educational programs, and teachers will be forced to "[jump] from an ever-changing series of curricular and pedagogical bridges as opposed to collaborating and employing available resources to build their own” (p. 13).

Researchers such as Catling (2013), Clayton (2007) and Voogt et al. (2011), studying teacher curriculum makers in collaborative settings, demonstrate that the collective nature of the curriculum design carried out by participants had positive effects on the shaping of teachers' attitudes and beliefs, and led to feelings of liberation instead of isolation, as well as 
perseverance in curriculum making that was driven by changing convictions. In short, collaboration led to greater agency.

Rivera Maulucci et al. (2015) also found, in their study of science teachers in a 14week professional development seminar, that collectively, four of the teachers were able to reflect on and modify the mandated science curriculum, and to enact their modifications, a feat that proved more difficult individually. While teacher collaboration with other teachers promotes agency, collaboration with mentors has also been shown to create spaces for teacher agency; Bieler (2013) notes that through holistic mentoring of four new teachers, she was able to create openings for their voices, listen for and inquire about pedagogical possibilities, and to aid in the cultivation of teachers' holistic, agentive instruction.

Teacher agency is also collective in that engagement with and consideration of learners is critical to the agentive enactment of curriculum. Understanding learners' lived realities and funds of knowledge (González, Moll, \& Amanti, 2013) is foundational to shifts in pedagogy; for, without taking this into consideration, classroom interactions are deemphasized, and the transmission of neutral skills, content, and competencies directly from teacher to students is underscored (Eisner, 2009; Golden \& Womack, 2016). Teachers’ beliefs, values, and convictions that drive structurally transformative agency must take into account their relationships with and knowledge of their learners.

\subsubsection{Teacher agency as emergent}

Finally, and also in relation to its being ecologically and collectively influenced and structurally transformative in nature, teacher agency is understood to be an emergent phenomenon; its expression changes based on teachers' personal and professional 
experiences, objectives, and relationships, and the cultural, structural, and material aspects available to them within their contexts. Teacher agency considers the reflexive and creative characteristics of teachers who are able to act against societal restraints, as well as the supportive and constraining power of teachers' social and material environments (Priestley et al., 2013). Teacher agency is realized through one's relationship to past influences, orientations toward the future, and engagement with the present. It is not something one has or does not have, is or is not, but is rather something that is achieved (Priestley, Biesta, \& Robinson, 2015). It is not fixed, but fluid. Thus, there is hope that certain professional spaces, experiences, relationships, and resources may promote growth in agency over time.

\subsection{INFLUENCES ON TEACHER AGENCY}

The ecological, collective, and emergent nature of agency suggests that certain contexts and opportunities for reflection and collaborative action can work to either stifle or promote teachers' growth in agency. There are diverse contexts and experiences that have been shown to influence teacher agency. The impacts of teachers' past experiences, configurations of the future, perceived professional spaces, and curriculum making opportunities on teacher agency are treated in the studies described below. I consider these areas of influence because of their close relationship to the study at hand, with regard to both the ecological nature of agency and the nature of the collaborative.

The collaborative seeks to both meet teachers in their professional spaces and to cause teachers to "disrupt and reimagine" the beliefs that they have formed throughout their teacher education and career, exposing teachers' notions about their context, students, and curriculum, and leading them to reconceive of their professional spaces. The collaborative 
also offers teachers opportunities to engage in curriculum making, creatively configuring the future of their classrooms and instruction as they discover needs and problems, frame solutions, and build plans. This literature review describes what has been explored regarding the influences of past experiences, configurations of the future, professional spaces and curriculum making on teachers' agency, paving the way for this study, in which I approach the question of ecological influences on teacher agency from a different angle.

\subsubsection{The past, the future, and teacher agency}

Teachers' past experiences (comprising the iterational dimension of Priestley et al.'s [2013] ecological model), as well as their resolutions or plans for the future (or the projective dimension), have been shown to impact their agency in significant ways. Buchanan (2015) identified two types of teacher agency (stepping up and pushing back) that were profoundly influenced by teachers' previous professional experiences, which they enacted in the face of policy decisions that had power to deskill teachers. Similarly, Dierking and Fox (2013) found that teachers' participation in a National Writing Project (NWP) initiative boosted teachers' confidence as they received tools, strategies, and instructional resources, which in turn empowered them to innovate in their approaches to assessment and to try new strategies when others were found wanting. Finally, Simpson, Sang, Wood, Wang, and Ye (2018) argue, based on their study of three Australian urban primary teachers, that a central constraint on the profession is "the extent to which teachers' engagement with research and enquiry-oriented practice is embedded throughout the education system" (British Educational Research Association, 2014, p. 15). Simpson et al. (2018) suggest that one way to address this constraint is to introduce pre-service teachers to the concept of agency in 
their initial teacher education programs, citing Furlong (2015), who notes that these programs must be "expansive rather than restricted, [giving] teachers themselves the skills, knowledge and dispositions to lead the changes that are needed” (p. 38).

With regard to teachers' future configurations and their impact on agency, Tao and Gao (2017) studied how teachers enacted agency via facilitation of their own professional development during curricular reform at a Chinese University. They found that teachers' "identity commitments," or resolve to "be the kind of teacher they [want] to be" (Buchanan, 2015, p. 15) were an important component of teachers' identity that, in turn, influenced their agency. The participants in their study who had a firm identity commitment were not hindered by the marginalizing curricular reform or the pedagogical challenges that arose, but continued to engage in relevant research activities, such as initiating course improvement projects, writing textbooks, and exploring new areas for research; these individuals "enacted agency in individualized ways by fulfilling tasks and adopting strategic efforts to improve their performance," (Tao \& Gao, 2017, p. 352). Tao and Gao (2017) note that these teachers' professional commitments are oriented toward the future, but they develop out of prior experiences and contextual conditions as well, showing that Priestley et al.'s (2013) ecological model must be held together, with past, present, and future dimensions continuously acting upon one another and teachers' agentive action.

\subsubsection{Perceived professional spaces and teacher agency}

Teachers' perceptions of their professional spaces (the practical-evaluative dimension), as mentioned above, have also been shown to impact their exercise of agency. In a case study in which they observed and interviewed eighteen teachers from three 
countries, Oolbekkink-Marchand et al. (2017) were able to observe the relationship between contextual constraints and agency. The researchers found that the teachers were most often only willing to exercise agency, or to personally mobilize their beliefs, convictions, and values in the classroom to the degree that their perceived professional space allowed. If teachers perceived that they had much professional room to mobilize their ideologies, they often did mobilize them; on the other hand, if they perceived that there were firm boundaries and strict guidelines to which they had to adhere, they were often less willing to exercise agency beyond these guidelines. Interestingly, the eighteen teachers were chosen for the study because of their "exemplary initiatives related to exploitation of professional space in their practice" (p. 39), demonstrating that even for very strong teacher agents, their perceptions about their professional space influenced their achievement of agency.

Rivera Maulucci et al. (2015) similarly found, in their study of teachers in a 14-week professional development seminar, that structurally transformative agency was made possible only when deeper social structures of the teachers' school experiences were made more malleable, which provided occasion for "significant collective refashioning" (Rivera Maulucci et al., 2015, p. 64).

The influence of perceived professional spaces on teacher agency was also explored by Golden (2018). He conducted an interview study with six teacher participants in an alternative education setting. In these interviews, he found that teachers were greatly influenced by their perceived professional spaces, feeling that: (1) much of the curricula that they were enacting did not work in their classrooms, yet they felt forced to use it; (2) their classroom communities were threatened by outsiders dictating what goes on in them; (3) the metrics and evaluations measuring learning make it more difficult for them to know their students, their growth, and their needs; and (4) time for collaboration was no longer 
prioritized, thus decreasing teachers' potential effectiveness. Golden notes of his findings, "In essence, agency is reduced to compliance within mandated-from-above curricular and pedagogical decisions, and there is little space for collective, professional, and systematic sense-making of pedagogical practice" (p. 12). Teachers viewed their agency as being greatly impacted by their perceived professional spaces, sensing that more trust was placed by school leaders in prepackaged curriculum than in the educators.

Chisholm et al. (2019) found in their scoping review that teachers' perceptions of their professional spaces significantly impacted their enactment of agency. Several case studies showed that ELA teachers were constrained in their agency by scripted curricula and/or mandates from administrators as to how to use the materials (Vaughn \& Faircloth, 2011). Likewise, Williams (2018) found that some secondary ELA teachers felt they could not include spoken word poetry into their classroom, due to the prepackaged curriculum that they were expected to use.

While curricular mandates in the studies cited above are shown to be powerful in keeping teachers from expressing innovative agency, Pease-Alvarez and Samway (2008) found that the introduction of some curriculum mandates even caused previously agentive teachers to backslide in their exercise of agency. At a US West Coast elementary school where teachers were working in inquiry groups to move toward a learner-centered approach to literacy teaching, the district adopted and mandated a scripted reading program. PeaseAlvarez and Samway (2008) note that upon this change, teachers' agentive action was greatly diminished, as their instruction was decided for them. After the change, independent reading and literature circles were scarce, rushed report writing replaced writing workshop, and teachers "stopped focusing on the needs and interests of children" (p. 36). 
Starkey (2010) found that beginning teachers were constrained in their agency when they had limited access to resources such as laptops, projectors, online websites, and cameras, and Bieler et al. (2017) identified the inequitable distribution of resources, teaching assignments to lower-level academic classes and younger-level high school classes, and the greater likelihood of not being given a permanent classroom as factors that thwarted new high school teachers' agency.

Administrative support has been found to be especially crucial to teachers' exercise of agency. When administrators supported long-term, participant-driven, reflective professional development experiences, teachers experienced greater agency (Rubin \& Land, 2017). Administrative permission to try new things has also been demonstrated to support teachers' growth in agency. Baker-Doyle and Gustavson (2016) found this to be true in their data, where "the concept of permission, so often thought of as disempowering, was subverted by teachers to aid in their expansion of teacher agency and risk taking in their pedagogy" (p. 52). Likewise, Pease-Alvarez and Samway (2008) found that when faced with a scripted and mandated curriculum, even very experienced teachers who enacted agency in the midst of curricular reform felt indebted to the permission they had received from the administration.

\subsubsection{Curriculum making and teacher agency}

Research shows that perceived professional spaces have a clear impact on teachers' achievement of agency. Curriculum making opportunities, likewise, have been found to influence teacher agency. 
Catling (2013) performed a study of primary teachers who were involved in a Young Geographers Project, in which they engaged, albeit briefly, in collective curriculum making. The study found:

teachers felt liberated by the opportunity to make their own curriculum with their children in a subject they valued. They perceived that they had regained control of their subject, geography, and of decision-making about their teaching. This was a refreshing, almost novel, feeling for them, as they had often found themselves constrained by national and school prescriptions in their teaching across the curriculum. (p. 444)

Catling (2013) reports, based on his own study of primary teacher curriculum makers, and a body of research by other researchers (Cox, 2011; Kelly, 2009; Priestley et al., 2012), that in their curriculum making, these educators started to see themselves as having agency as teachers, able to actively and creatively wield their professional expertise and aspirations. The teachers felt that they were learning again, and not simply transmitting information.

In a study akin to Catling's, Clayton (2007) examined the experiences of three novice teachers in urban schools who carried out curriculum making projects as participants in a year-long professional development program. The culminating project for the novices involved the development and enactment of curricular projects, with the aim being that these projects would create spaces for first-year teachers to critically reflect and experience transformation in the way they viewed their own practice, their students, students' families, schools, and communities. Indeed, the experience of the curriculum projects provided the three teachers with opportunities to both take risks in curriculum making and to reflect on and analyze their learning. It is important to note that the risk taking of these teachers via curriculum innovation preceded changes in their thinking; the process engaged epistemological tensions and initiated meaningful reflection that, over time, yielded changes in their previous notions about teaching and learning. "So much of traditional teacher education and induction focuses on changing teacher thinking," Clayton notes, "yet these teachers' stories 
suggest that changes in practice may, indeed, precede conceptual changes" (p. 228), and thus, growth in agency.

The experience of the teachers in Clayton's (2007) study, who engaged in curriculum making within a professional development program, demonstrates the power of the curriculum making process to increase teacher agency. Taking part in such a project necessarily reflects and calls into question the beliefs and values of teachers, and opens to them the possibility of broader professional spaces and structurally transformative action.

\subsubsection{Teacher identity and teacher agency}

In spite of the evident roles that teachers' past experiences, future goals, perceived professional spaces, and curriculum making opportunities play in the achievement of agency, it is important to note that teacher agency is not completely dependent upon these influences. In fact, agency often precedes the broadening of perceived professional spaces and curriculum making for teachers. Just as iterational, practical-evaluative, and projective influences (Priestley et al., 2013) overlap and interact in dynamic and dialectic relationship to one another, so agency is not only acted upon by one's contexts and experiences, but also acts on them.

Priestley et al. (2012) performed a case study of three teachers at a high-performing school in Scotland in which the power of agency to influence perceived professional spaces and curriculum making was apparent. At the school, policy and school accountability were strict, and teachers were expected to cover the same material as other teachers in their sections. Discussions at the administrative and faculty levels focused on student success in reaching benchmarks. For all of this, the three teachers in Priestley et al.'s (2012) study took 
very different approaches from one another. One was what Shawer (2017) would call a curriculum transmitter, adhering strictly to the textbook. This teacher "seemed to enact a constrained form of agency framed by unsubstantiated projections upon students and a desire to maintain control through a mixture of performance and discipline" (Priestley et al., 2012, p. 207). He viewed students as unmotivated, as having a deficit in both motivation and the ability to learn without him being "on stage." Another of the three teachers was what Shawer (2017) deems a curriculum developer. He felt that he was constrained in some ways by the textbook and the standards he needed to teach, but he still wrote his own notes, believing the book to be unhelpful in many ways. He altered the prepackaged curriculum to make it more accessible and interesting to students. The last teacher involved in the study is what Shawer calls a curriculum maker. She covered the same material, but did not use a textbook, and her class regularly involved high-level thinking, interactive instruction, and a variety of instructional methods. Priestley et al. (2012) note that this teacher did not have a deficit perspective of students, but believed that students possessed inherent potential, and it was her job to bring it out. These attitudes about her students and her own identity as their teacher greatly informed her disposition toward curriculum making, and the need to act in accordance with her beliefs and convictions led her to design curriculum experiences that were more suitable to her context and purposes, and her students' engagement, experience, desires, and needs. Curriculum making was a fruit of teacher agency. While the professional space in which teachers existed had clear limitations, agency allowed the curriculum maker to broaden her professional space and to make curriculum.

Day (2018) notes, in a similar vein, that while the structures and mandates that play on teachers' agency are undeniably powerful, "they need not determine how individuals feel or act." He continues, “There is a wide range of international research on improving, effective, 
and successful schools which demonstrates how teachers mediate, resist, and find productive room to maneuver, asserting their individual and collective sense of agency within a sense of positive identity" (p. 63). Teachers' sense of efficacy and agency will never be completely predetermined, Day (2018) argues, because they are impacted by the dynamic relationship among individual strength of purpose, as well as the emotional pressures of workplace and external social and policy settings.

In some contexts, agency seems to be dependent upon institutional cultures, as teachers' agency is shown to be supported by a sense of community and limited control of teachers' work and constrained by hierarchical structures and bureaucratic management (Hökkä \& Vähäsantanen, 2013; Priestley et al., 2012). In other teaching contexts, however, Wang, Mu, and Zhang (2017) note that "teacher agency seems to be fraught with freedom and initiative, autonomously responsive to contextual dynamics” (p. 116), as teachers find ways to go above and beyond the expectations for their role, or to "push back" against policies with which they disagree (Buchanan, 2015).

\subsection{CHALLENGES TO RESEARCHERS}

Many theoretical and empirical research studies have examined the relationship between teachers' past experiences and agency (Buchanan, 2015; Dierking \& Fox, 2013; Furlong, 2015; Simpson et al., 2018), as well as the relationship between their configurations of the future and agency (Tao \& Gao, 2017). Others have examined the influences of perceived professional space in the workplace on teacher agency (Baker-Doyle \& Gustavson, 2016; Bieler et al., 2017; Golden, 2018; Oolbekkink-Marchand et al., 2016; Pease-Alvarez \& Samway, 2008; Priestley et al., 2015; Rivera Maulucci et al., 2015; Rubin \& Land, 2017; 
Starkey, 2010; Timberlake et al., 2017; Vaughn \& Faircloth, 2011; Williams, 2018). The relationship between curriculum innovation and teacher agency has also been welldocumented (Catling, 2013; Clayton, 2007; Cox, 2011; Harste \& Short, 2010; Kelly, 2009; Priestley et al., 2016; Priestley et al., 2012; Shawer, 2010; Shawer, 2017). Additionally, various studies have found that teachers' agency is not entirely dependent upon ecological influences at all, but rather, teachers' sense of personal and professional identity (Buchanan, 2015; Day, 2018; Tao \& Gao, 2017).

In spite of the literature that is replete with findings regarding teacher agency, none of these studies has sought to examine in a comprehensive way the factors that, over time, have contributed to teachers' conceptualizations about curriculum and their roles in curriculum. In other words, the studies have not sought to examine the complex relationship among curriculum making, agency, and other influences on teachers' development as curriculum makers and agents. Moreover, except for Catling's (2013) and Clayton's (2007) studies, none of the studies regarding curriculum making and agency has focused on the context of an innovative professional collaborative. Catling's (2013) study is limited in scope because the teachers in the cohort under study met only two times and the cohort strictly involved geography teachers, and Clayton's (2007) study is limited due to its involvement of only three beginning teachers. Additionally, many of the studies that examine the impacts on teachers' agency focus on teachers of only one content area in one school, and thus do not study the influence of collaborating across content areas and school settings. Finally, many studies focused only on those influences that supported or constrained teacher agency and were limited in their scope, not often taking into consideration those factors that could have supported teacher agency, but did not, nor the influences that could have constrained teacher agency, but did not. 
The present study builds on the findings of research literature by comprehensively examining the influences on teachers' curricular beliefs and roles, both historically and in relation to the context of a yearlong innovative professional collaborative. Diverse perspectives, content areas, career stages, school settings, and professional and educational experiences characterize the participants in the collaborative, thus offering greater potential for understanding the various and complex influences that teachers perceive to contribute (and conversely, not to contribute) to their agency, including the influence of the collaborative itself.

\subsection{SUMMARY}

In this chapter, I have situated teacher agency as a transformative, ecological, collective, and emergent phenomenon; reviewed theoretical and research literature on teacher agency and its relationship to teachers' past experiences, future configurations, perceived professional spaces, curriculum making, and teacher identity; and called for more comprehensive examination of the influences that affect teachers' curricular perspectives and roles, and thus, their agency. In the next chapter, I present the design of this dissertation study, in which I used inductive analytic methods to examine teachers' perceptions of curriculum and their roles in curriculum over time and in various contexts, and how these perceptions — and ultimately their achievement of agency — were influenced by their participation in the collaborative. 


\subsection{METHODOLOGY}

\subsection{INTRODUCTION}

In this study, I addressed the following major research questions:

1. How do teachers perceive curriculum and their roles in curriculum? In what ways do they perceive their curricular conceptions and practices to be influenced by:

a. their past teaching experience?

b. their teacher education program?

c. their perceived professional space in the workplace (culturally, structurally, and materially)?

d. their short-term and long-term objectives for their students?

2. How do teachers view their participation in the innovative professional collaborative as contributive to their conceptualizations about and relationship with curriculum:
a. with regard to their beliefs?
b. with regard to their written plans?
c. with regard to their classroom practice?

In order to answer these questions, and to provide a thick and unified description of teachers' perceptions and experiences, I utilized qualitative case study methods, as well as data-gathering techniques informed by life history research. I gathered survey, interview and video data, as well as teaching artifacts, from a diverse group of teacher participants who 
were members of the collaborative. Teachers' survey responses, their innovative projects, and the interview and video transcripts served as the four data strands in this study. I analyzed all data using (1) open coding; (2) focused coding; (3) coding using pre-established codes; and (4) cross-case analysis. These data analysis methods yielded an understanding of teachers' perspectives on the influences on their curricular conceptions, practices, and agency, and of how their beliefs and practices have evolved, especially during their participation in the collaborative.

\subsubsection{Methodological rationale}

Qualitative research was utilized as the mode of inquiry for this research study, as it involves rich descriptions of people, places, and conversations, addressing questions that may not be easily handled by statistical procedures (Bogdan \& Biklen, 1992). Qualitative research seeks to understand the meaning others construct (Bogdan \& Biklen, 1992; Merriam, 2007). It is also of use in studies in which the researcher is the primary instrument for data collection and analysis; has contact with participants; utilizes a nonrandom sample selection; and employs an inductive research strategy (Merriam, 2007).

I used qualitative research methods for this study because I sought to gain a better understanding of individual teachers in relation to various ecological influences (iterational, practical-evaluative, and projective) (Priestley et al., 2013), and within the context of the collaborative itself. Because my primary focus in this research study was on the way that teachers in the collaborative perceived their curricular conceptions and practices to have been influenced and to evolve in various ways, qualitative methods, with their focus on the

meaning that people construct, were suitable; this attention to the perspective of the teacher 
is evident in the research questions, as well as the structure of the survey, the interview questions, and the prompts for teachers' video diaries. The data sources themselves—survey, interview, video data, and the collection of artifacts - are characteristic of qualitative methods.

In the design of this research study, I drew particularly on qualitative case study methods, as case study is concerned with the meaning that people make of their lives in very specific contexts, and is appropriate for studies seeking to answer 'how' and 'why' questions (Yin, 1994). Qualitative case study is interested in "the local particularities of some abstract social phenomenon" (Dyson \& Genishi, 2005, p. 3), often focusing on individuals, local activities, and particular places. This particular case study is bound by the context of the innovative professional collaborative: the individuals who took part in it and the local activities in which they were involved. Qualitative case study allowed me to understand the phenomena of teachers' evolving curricular conceptions, practices, and agency, from teachers' perspectives and within the confines of the collaborative. I sought, in this descriptive cross-case study, to present a detailed account from teachers' perspectives, not being "guided by generalizations nor motivated by a desire to form them" (Merriam, 2007, p. 38). As teachers' perspectives were inherent in all data sources, the study resulted in rich, thick description of their evolving curricular conceptions, practices, and agency through their own lenses.

A life history orientation to research also informed this research study, as it provided an approach to the structure and types of questions asked during the interview and to prompt the video diaries. Through life history research, insight can be gained into the experiences of others in a particular context, exploring how individuals walk, talk, live and work in this context (Cole \& Knowles, 2001). This aspect of life history research is related to 
the practical-evaluative dimension of Priestley et al.'s (2013) understanding of agency, which accounts for the cultural, structural, and material influences on teachers' achievement of agency. Life history interviews also ask participants to reflect on their experiences and to tell the story of their lives (Atkinson, 2012; Cole \& Knowles, 2001). In this way, life history research is useful for understanding the iterational dimension of agency (Priestley et al., 2013), which is influenced by an individual's life history and professional history. Qualitative case study methods, as well as life history methodology, are consistent with the objectives of this research study, its context, and the data sources that will be used. In their focus on particular contexts, participants' construction of meaning and experiences, and "the messy complexity of human experience" (Dyson \& Genishi, 2005, p. 3), these methods are appropriate for addressing the ecological influences on teachers' conceptions and practices, the contact zone of the collaborative, teachers' diverse perspectives, and the dialogic nature of curriculum and curriculum making.

\subsection{CONTEXT AND PARTICIPANTS}

\subsubsection{The innovative professional collaborative}

I chose the innovative professional collaborative of which teacher participants were a part for the purposes of this research study in order to examine, from teachers' perspectives, the influence of this professional development experience on teachers' curricular conceptions and practices. It served, by virtue of the processes through which teachers were led while in the collaborative, as a contact zone for the ecological dimensions impacting teacher agency: the iterational, practical-evaluative, and projective dimensions (Priestley et al., 
2013). The collaborative was based in a large, urban school district in the southeastern

United States, where it involved over fifty teachers from five secondary schools.

The collaborative began during the 2017-2018 school year, when Gwen2 was hired by the principal of Applewood High School as a goal clarity coach. She shared that when she was initially hired, the principal at the time, Dr. Ian Morley, did not know "what he wanted to do with [her]." He gave her the simple edict, "Help our teachers innovate." She spent three weeks observing and meeting teachers and getting a sense of the culture at Applewood, and then she began to formulate the idea for the collaborative. She noted in an interview that her experience of having simultaneously been a classroom teacher and an entrepreneur inspired her design of the collaborative. As an entrepreneur, she had been in meetings where people "were approaching things differently," she said. "And just a different kind of philosophy about approaching problems or creating or thinking through ideas...it kind of rubbed off on me." She explained that in the entrepreneurial world, there exists something called an 'accelerator,' which she described this way:

[E]ssentially it's like, 'I have this great idea for a new app or a new product or a new business concept or whatever. And I'm gonna submit this idea, and then I'm gonna go into this program and as a result, I'm gonna get resources and I'm gonna get mentorship and I'm gonna have this, you know, confined space, where I'm able to like, try things to make this idea or this business grow.'

After thinking over possible directions to help teachers innovate, it clicked in Gwen's mind:

[1] kind of was this 'aha' of like, 'Wait a minute. What if there were a teacher accelerator?' Where essentially, like, teachers come in, I have this idea, I need support, I need mentorship, I need resources, I need thought partners. I'm not necessarily getting it. And so, this is a place and a space for me to do that.

Gwen recognized that while entrepreneurs had opportunities "to create and thrive and grow," she did not see anything similar for teacher innovators in the profession.

\footnotetext{
${ }^{2}$ All names for individuals, organizations, and places are pseudonyms.
} 
Based on her own experiences as a teacher and an entrepreneur, as well as a freelance writer, in addition to her observations of and relationships with other educators, Gwen professed to value teachers' recognition of their agentive potential, teacher innovation, and close mentorship relationships; as well as schools' and districts' commitment to trust teachers, allow innovative teachers to lead in schools, provide opportunities for teachers to pursue valuable offsite experiences, and encourage teachers' relationships with one another. The culmination of these beliefs, convictions, and experiences led to Gwen's design and implementation of the collaborative.

Gwen recruited and took on the role of teacher mentor for eight teacher participants at Applewood High School. The group met eight times during the school year, between November and May, at a nearby pub, in order to discuss and rethink their conceptions of learning, school, and curriculum; to define problems, brainstorm solutions, plan for implementation of their ideas; to construct more refined plans after implementation; to reflect; and to share their ideas and results. In between these meetings, Gwen met regularly with the teachers in their classrooms and in her office, seeking to challenge, encourage, and be a sounding board for them. Apart from designing, enacting, and reflecting upon innovative plans, teachers' experiences in the collaborative involved their shadowing and interviewing students, and, at the end of the year, pitching their ideas, process, results, and next steps to community stakeholders during a Demo Day.

Before the 2018-2019 school year, Gwen was invited by the district to expand the collaborative from one school to five, where forty-one teacher participants involved themselves, and fifteen dedicated teacher mentors were instated to help support the them. Four of the teacher mentors were involved in the 2017-2018 collaborative, while the other eleven were not previously involved; however, all were chosen and placed at various schools 
by Gwen upon their application to the role. Perhaps of significance, the eight teachers involved in the first year of the collaborative received stipends for their involvement, and both mentors and teachers received stipends during the second year.

During the second year, Gwen also invited six diverse community advisors, and many community partners into the collaborative's sphere of influence, who assisted it in various ways, from hosting workshops and public radio education panels to providing food and meeting locations. The community advisors ranged from a business executive and a dean of education to a director of economic opportunity at a nonprofit organization and a music education manager at a public media outlet; the community partners consisted of a coffee shop, a soccer club, a brewing company, a science center, a healthcare provider, grocery stores, and various restaurants.

The teachers involved in the collaborative were referred to as "teacher founders" and the collaborative was called an "educator accelerator," being modeled after business startup philosophy, "but for teachers who have innovative ideas for deeper learning and classroom practice." "We are the platform for the world's best untapped CEOs," the website read. The collaborative gave teachers the opportunity to go through a series of startup steps, combining "human-centered design with entrepreneurial philosophy to develop a program that is authentic, personalized, empathy-based \& iterative."

The steps through which teachers worked during their time in the collaborative were the following: (1) Disrupt and Reimagine; (2) Discover; (3) Frame; (4) Build; (5) Break; (6) Bridge; and (7) Demo. During the "Disrupt and Reimagine" phase, teachers worked together to "rethink learning in their classrooms by disrupting their perspectives on how school could be." In this phase, teachers engaged with the iterational dimension in the model on teacher agency (Priestley et al., 2013), as well as the practical-evaluative dimension, which involves 
the freedoms and constraints of teachers' contexts. In the "Discover" phase, teachers shadowed, interviewed and conducted research involving students in their classrooms, seeking to understand the school experience from a different point of view. Again, teachers engaged with the practical-evaluative dimension of their workplace, as they deepened their knowledge of their current context and their students' experiences. In the "Frame" phase, teachers named a problem that they saw in the school or in their classroom, brainstormed solutions to it, and created a plan for implementation of one or more of their ideas. In this way, teachers engaged with the projective dimension, creatively configuring future plans as a solution to a perceived problem. In the "Build" phase, teachers implemented their plan, and recorded input and output metrics to determine needs and next steps. In the "Break" phase, teachers broke down these results in order to construct more refined plans of action. During the "Bridge" phase, teachers reflected on and synthesized their processes from the "Discover" phase to the "Build" phase and planned to share their ideas and results. Finally, during the "Demo" phase, teachers shared their ideas, processes, results, and objectives with community education stakeholders during Demo Day. The four final phases of participants' experience in the collaborative involved all three ecological dimensions of teacher agency, just as the first three did (Priestley et al., 2013); it is clear that the ecological dimensions of teacher agency and the processes of the collaborative are conceptually very well-aligned. Because the ecological dimensions were all deeply engrained in the processes of the collaborative, it served as a contact zone for teachers—a place where multiple dimensions of personal and professional experience, and various discourse repertoires meet, creating productive tension. The contact zone of the collaborative served as a ripe context for potential growth or change in teacher agency and the ideological becoming of participants. 


\subsubsection{Selection of participants}

The selection of participants is a crucial component of every research design. In order to appropriately address my research questions in this study, the participants in this study were a group of diverse teacher participants in the innovative professional collaborative during the 2018-2019 school year. Teacher participants were to be diverse in their teacher education experiences, school settings, length of time teaching, and content areas, so as to provide a sample whose agency likely stemmed from various ecological influences. In this way, I was able to examine the influence of the collaborative in a more comprehensive way, through the lenses of participants from all walks of personal and professional life.

Because of the importance of having a variety of teacher perspectives, seven participants were chosen to participate in the entirety of the study; however, as is typical of qualitative studies, which usually rely on a small number of participants, this was the maximum number of participants I was willing to allow, in order to be able to provide an indepth analysis and description of teachers' past and present curricular conceptions and practices, as well as the influences on these conceptions and practices (Emerson et al., 2011). In the initial phase of research, I chose teacher participants on the basis of their membership in the collaborative and their willingness to participate in the study, as demonstrated by their response to an email invitation; this invitation also included an explanation of the study, clearly describing the research study's purposes, the procedures, and the steps used to maximize confidentiality and to minimize risk. In this phase of the study, all teachers in the collaborative were welcome to take part, and those interested notified me. I received some interest from participants upon my initial email to all 
participants in the collaborative, but gained more participants upon meeting several of them at Demo Day and explaining the study to them. Once teachers agreed to be a part of the study, they took the teacher background survey in order to determine their eligibility to continue to the interview, video diary, and document collection portions of the study. This survey also proved beneficial throughout the rest of the study. All participants who took the survey were quite diverse, however, one of these two did not continue with the study, because she did not submit the video diaries for the study. Thus, eight potential participants became seven. The following table highlights in brief who the participants were.

Table 1. The Teacher Participants

\begin{tabular}{|c|c|c|c|c|c|c|}
\hline $\begin{array}{l}\text { Participant } \\
\text { Pseudonym }\end{array}$ & School & $\begin{array}{c}\text { Years in } \\
\text { Collaborative }\end{array}$ & $\begin{array}{c}\text { Years } \\
\text { Teaching in } \\
\text { Secondary } \\
\text { Education }\end{array}$ & $\begin{array}{l}\text { Subject } \\
\text { Taught }\end{array}$ & $\begin{array}{c}\text { Type of } \\
\text { Teacher } \\
\text { Education }\end{array}$ & $\begin{array}{c}\text { Level of } \\
\text { Education } \\
\text { Achieved }\end{array}$ \\
\hline Tami & $\begin{array}{c}\text { Applewood } \\
\text { High } \\
\text { School }\end{array}$ & 2 & 14 & English & Traditional & Master's \\
\hline Kellen & $\begin{array}{c}\text { Applewood } \\
\text { High } \\
\text { School }\end{array}$ & 2 & 9 & Science & $\begin{array}{l}\text { Alternative } \\
\text { Certification }\end{array}$ & Master's \\
\hline Walt & $\begin{array}{c}\text { Applewood } \\
\text { High } \\
\text { School }\end{array}$ & 2 & 5 & History & Traditional & Master's \\
\hline Robert & $\begin{array}{l}\text { Cromwell } \\
\text { Middle } \\
\text { School }\end{array}$ & 1 & 6 & Science & $\begin{array}{c}\text { Non- } \\
\text { traditional }\end{array}$ & $\begin{array}{l}\text { Doctoral } \\
\text { Degree }\end{array}$ \\
\hline Sydney & $\begin{array}{l}\text { Cromwell } \\
\text { Middle } \\
\text { School }\end{array}$ & 1 & 2 & English & Traditional & Bachelor's \\
\hline Hannah & $\begin{array}{l}\text { Whitfield } \\
\text { Middle } \\
\text { School }\end{array}$ & 1 & 5 & English & $\begin{array}{c}\text { Apprenticeship } \\
\text { Program }\end{array}$ & Master's \\
\hline Michelle & $\begin{array}{l}\text { Norton } \\
\text { Middle } \\
\text { School }\end{array}$ & 1 & 17 & Science & Traditional & Master's \\
\hline
\end{tabular}


Three of the teacher participants, Tami, Kellen, and Walt, were in their second year of the collaborative, having been mentees in the program at Applewood High School during its year of conception. During the 2018-2019 school year, they served as mentors, with Tami mentoring the teachers at Cromwell Middle School, Kellen mentoring at Whitfield Middle School, and Walt mentoring at Cooper Middle School (a school that did not have any participants in this study). At first, I was hesitant to include teachers who were mentors in the collaborative during the 2018-2019 school year, but upon further thought, I decided that this was just one more area of diversity amongst the participants, which would allow me to consider possible differences between the experience of being a participant in the collaborative when it was based at one school with only eight teachers in it, versus being a participant in it during its year of expansion to five schools, when it began to receive oversight from a district, rather than school level. When I refer to Tami, Kellen, and Walt in this study, I refer to them in this order simply due to their different years' experience as teachers, and I refer to them before the mentees simply because of their longer experience in the collaborative.

Robert, Sydney, Hannah, and Michelle were mentees in the collaborative during the 2018-2019 school year. Robert and Sydney were teachers at Cromwell Middle School, Hannah taught at Whitfield Middle School, and Michelle taught at Norton Middle School. Robert and Sydney chose to create and enact classroom-based instructional designs during their time in the collaborative, and for this reason, along with their being a part of the same school, I refer to them first out of the four mentee participants. Hannah and Michelle chose to create and enact school-wide innovative designs during their participation, and for this reason, I refer to them last. 
As can be seen in the Table above, the seven teacher participants were not only diverse in the number of years they spent in the collaborative, but in their years of K-12 teaching experience, which spanned from 2 to 17 years, the subjects they taught, the type of teacher education they received, and the level of education they had received, with Sydney holding a bachelor's degree, most participants holding master's degrees, and Robert having completed an Ed.D.

\subsubsection{The schools}

The four schools where the participants taught, Applewood High School, Cromwell Middle School, Whitfield Middle School, and Norton Middle School, are all a part of a large, public, urban school district in the southeastern United States, and share many similarities, but some key differences as well.

Table 2. The Schools

\begin{tabular}{|c|c|c|c|c|}
\hline School & $\begin{array}{c}\text { Number of } \\
\text { Students }\end{array}$ & $\begin{array}{c}\% \text { Minority } \\
\text { Enrollment }\end{array}$ & $\begin{array}{c}\% \text { Free and } \\
\text { Reduced Lunch }\end{array}$ & $\begin{array}{c}\text { State Ranking } \\
\text { out of 1,251 } \\
\text { Schools }\end{array}$ \\
\hline $\begin{array}{c}\text { Applewood } \\
\text { High School }\end{array}$ & 1,590 & $56 \%$ & $54 \%$ & 998 \\
\hline $\begin{array}{c}\text { Cromwell } \\
\text { Middle School }\end{array}$ & 829 & $44 \%$ & $73 \%$ & 1,220 \\
\hline $\begin{array}{c}\text { Whitfield } \\
\text { Middle School }\end{array}$ & 1,254 & $53 \%$ & $56 \%$ & 1,144 \\
\hline $\begin{array}{c}\text { Norton Middle } \\
\text { School }\end{array}$ & 1,353 & $49 \%$ & $46 \%$ & 259 \\
\hline
\end{tabular}

Table 2 provides basic information about the four urban schools at which teachers were employed at the time of the study. These schools are all a part of the Washington 
County Public School District, which operates 169 schools from Pre-K through 12 th grade, with more than 98,000 students. 125 languages are spoken by students in the district, and 62 percent of students are eligible for free or reduced-price meals. Overall, the racial/ethnic demographics in the district's public schools are 37\% African American, 49\% white, and $14 \%$ other. While the neighborhoods in the city are highly segregated, bussing and desegregation movements of the 1970s and 1990s have had lasting effects on the diversity of most schools in the district, which tend to have a population of African American students ranging from 15 to $50 \%$ of the student body. The district has more than 18,000 employees, with 6,738 serving as teachers.

Applewood High School, where Tami, Kellen, and Walt taught at the time of the study, has 1590 students, 87 full time teachers, and its minority enrollment is 56\%. Apart from 38\% African American students, this minority enrollment consists of 11\% Hispanic students, $4 \%$ Asian, and 3\% two or more races. $54 \%$ of students receive free and reduced lunch at Applewood. Applewood ranked 998 out of 1,251 schools in the state on the basis of Math and Reading/Language Arts test scores and is considered to be in the bottom $25 \%$ of schools by these measures. However, $46 \%$ of the student body participates in AP classes, and Applewood has a 90\% graduation rate, which is just higher than the state average of $89 \%$. Applewood was described by Gwen as a place where teachers have a lot of autonomy, and where the principal encourages innovation amongst the teachers. This is where the collaborative began in November of 2017 with the eight original teacher participants. Four of these original teachers became mentors to teachers in the five other schools who participated during the 2018-2019 school year, three of whom were Tami, Kellen, and Walt.

Cromwell Middle School, serving grades 6 through 8, as do most middle schools in the district, has 829 students and 48 teachers, and a minority enrollment of $44 \%, 37 \%$ of 
whom are African American. Cromwell ranked 1,220 out of 1,251 schools in the state according to the test score measures mentioned above and is thus considered to be in the bottom $3 \%$ of schools in the state. $73 \%$ of the students at Cromwell receive free and reduced lunch. Gwen described the principal of Cromwell as her former principal at another school and a good friend of hers. "He was the first one to sign up for the program [during its second year]," she said. "He was incredibly enthusiastic and supportive of the program." Robert and Sydney were among several teachers involved in the Cromwell cohort during the 2018-2019 school year.

Whitfield Middle School serves 1,254 students and has 77 teachers. Its minority enrollment is $53 \%, 34 \%$ of whom are African American, and $12 \%$ of whom are Hispanic. Whitfield ranked 1,144 out of the 1,251 schools in the state with regard to test stores and is considered to be in the bottom $10 \%$ of schools in the state. $56 \%$ of students receive free and reduced lunch. Gwen shared that Whitfield's 'vibe' was similar to that of Applewood, where teachers have a lot of autonomy and "the principal is willing to give high quality teachers room to innovate.” Hannah was a mentee in the Whitfield cohort during the 2018-2019 school year.

Finally, Norton Middle School, while sharing a similarly high minority enrollment and number of students as the other schools, is very different from them by other measures. 1,353 students attend Norton, with a minority enrollment of $49 \%, 37 \%$ of whom are African American. Norton ranked 259 out of the 1,251 schools in the state and is considered to be in the top $25 \%$ of schools. The strong magnet programs available to students at this school account, perhaps, for the disparity in its ranking compared to the other three schools, because it is very selective. $44 \%$ of students receive free and reduced lunch. Gwen shared that at Norton, the principal was not engaged in the cohort, and that the cohort was 
“constant drama." Gwen acknowledged that the principal might have been very involved and encouraging behind the scenes, but was not present at any of the events. Michelle was a part of the Norton cohort during the 2018-2019 school year.

\subsection{DATA COLLECTION}

In order to construct teacher cases, I used four methods of data collection over the course of three months: (a) short-answer online surveys; (b) audio-recorded interviews with teachers and the lead teacher mentor; (c) video transcripts from footage collected from individual participants and the Demo Day; and (d) teaching artifacts created by teachers during their time in the collaborative. The variety of data sources served to triangulate the data (Merriam, 2007). I sought, utilizing all data sources, to understand the evolution of teachers' curricular conceptions, practices, and agency, and the influences behind teachers' exercise of structurally transformative agency, including the impact of the collaborative. With this understanding, schools and teacher preparation programs alike might be able to support teachers' growth in innovative agency, thus promoting instruction that is responsive to the context and students' needs, engagement, and long-term learning.

\subsubsection{Surveys}

I utilized surveys in order to choose seven unique participants who took part in the study. Teachers who agreed to be a part of the study took a brief, short-answer, online survey (see Appendix A) in order to determine their eligibility to continue in the rest of the

data collection process. Using this teacher background survey, I gathered information about 
teachers' backgrounds and experiences, as well as their curricular conceptions, objectives, and practices. Additionally, teachers shared perceptions regarding their exercise of agency. Teachers' responses were initially reviewed for distinctions among their personal interests, their teaching career (including length of time teaching, content area(s), place of employment, and grade levels taught), their teacher education, their vision for their students, their preferred methods, a description of their current curriculum, and their perspective on the alignment between their beliefs and practice. In view of responses to this survey, seven diverse teacher participants were chosen to take part in the rest of the study. In this way, I ensured that the study was not limited to teachers with similar ecological influences playing on their agency (such as teaching at the same school or the same content area), and that a variety of influences, as well as the outworking of diverse contact zones could be explored.

\subsubsection{Interviews}

Interview is a salient data source to most qualitative case studies. In this study, it served to answer both research question 1 and research question 2 (see Table 3). Patton (1990) notes, "We interview people to find out from them those things we cannot directly observe" (p. 196), such as feelings, thoughts, intentions, behaviors that took place formerly, situations that could not be observed, how people understand the world, or the meanings they attach to what goes on in the world. Because this study was concerned with the participants' past and present beliefs about teaching and learning, their former practices, and historical influences on these practices, interview was a necessary data source. Apart from the brief survey given during the sampling process, each teacher participant was interviewed once individually for 40 to 90 minutes (see Appendix B). The facilitator of the collaborative, 
Gwen, was also interviewed in order to understand the vision, mission, and structure of the collaborative (see Appendix D); her perspective regarding the evolution of teachers' perceptions of and roles in curriculum; the influences that shape teachers' conceptualizations and practices; and the witnessed impact of the collaborative, in particular, on teachers' agency. Interviews provided a way for me to probe any apparent inconsistencies among teachers' past experiences with curriculum, beliefs about curriculum, and the design of their curricular projects. The semi-structured nature of the interviews allowed for data collection to be focused on the overarching questions that I sought to answer in this study, but flexible enough for new questions and themes to emerge. Interviews were recorded and transcribed in their entirety.

\subsubsection{Video transcripts}

Video transcripts comprised a significant data source in this study, as well, providing data related to research question 2. In two video diary entries from the end of the school year, teachers reflected, using Flipgrid, on how their participation in the collaborative contributed, from their perspective, to their conceptualizations about and relationship with curriculum. Guided by questions and prompts (see Appendix C), teachers shared, in the form of two five-minute entries, about the ideological and everyday impacts of the collaborative on their belief systems and the practices. An entry can only be a maximum of five minutes long when using Flipgrid. Transcripts from video diaries were used to answer research question 2 because the video diary is an easy, fast, and informal way to capture data, and may have put less of a burden on the busy teachers, who could capture their thoughts at a convenient and unscheduled time. The five-minute maximum for teachers' responses to 
each of parts 1 and 2 of the video diary protocol may also have served to streamline teachers' responses to the prompts, providing different types of descriptions than those that teachers offer when time was not strictly bounded, as in the interview. Another video transcript source was provided from the collaborative's Demo Day at the end of the school year, in which participants shared their work from the school year and reflected on the experience. It is important to note that I did not analyze video data itself, but rather the transcripts that were produced from the video data. All participants, save for Robert, spoke and were recorded at Demo Day, and I transcribed their words in full.

Table 3. Research Questions with Corresponding Data Sources and Analytic Tools

\begin{tabular}{|c|c|c|}
\hline Research Question & Data Source & Analytic Tool \\
\hline $\begin{array}{l}\text { How do teachers perceive curriculum } \\
\text { and their roles in curriculum? In what } \\
\text { ways do they perceive their curricular } \\
\text { conceptions and practices to be } \\
\text { influenced by: } \\
\text { a. their past teaching experience? } \\
\text { b. their teacher education } \\
\text { program? } \\
\text { c. their perceived professional } \\
\text { space in the workplace } \\
\text { (culturally, structurally, and } \\
\text { materially)? } \\
\text { d. their short-term and long-term } \\
\text { objectives for their students? }\end{array}$ & $\begin{array}{l}\text {-Surveys } \\
\text {-Individual interview } \\
\text { transcripts }\end{array}$ & $\begin{array}{l}\text {-Open and focused } \\
\text { coding } \\
\text {-Coding using pre- } \\
\text { established codes } \\
\text {-Cross-case analysis }\end{array}$ \\
\hline $\begin{array}{l}\text { How do teachers view their } \\
\text { participation in the innovative } \\
\text { professional collaborative as } \\
\text { contributive to their conceptualizations } \\
\text { about and relationship with } \\
\text { curriculum: } \\
\text { a. with regard to their beliefs? } \\
\text { b. with regard to their written } \\
\text { plans? } \\
\text { c. with regard to their classroom } \\
\text { practice? }\end{array}$ & $\begin{array}{l}\text {-Video transcripts from } \\
\text { Flipgrid video diaries } \\
\text {-Video transcripts from } \\
\text { the collaborative's } \\
\text { Demo Day } \\
\text {-Teachers' instructional } \\
\text { plans }\end{array}$ & $\begin{array}{l}\text {-Open and focused } \\
\text { coding } \\
\text {-Coding using pre- } \\
\text { established codes } \\
\text {-Cross-case analysis }\end{array}$ \\
\hline
\end{tabular}




\subsubsection{Teaching artifacts}

Teaching artifacts provided the final data source, as they are "a reliable source of data concerning a person's attitudes, beliefs, and view of the world" (Merriam, 2007, p. 116). They also provided data relevant to research question 2. Before participants recorded their video diaries, they were asked to provide a project that they undertook during the school year, on which they worked during their participation in the collaborative. In their video entries, participants reflected on their decision-making with regard to their projects, and the influence of the collaborative on their taking up or rejecting various objectives, content, materials, strategies, or sequences in the design of their unit or innovative design.

\subsection{DATA ANALYSIS AND INTERPRETATION}

As is typical of qualitative research, I took an inductive, concept-building approach to data analysis in this study (Merriam, 2007). While analysis of data occurred throughout the data collection phase, four discrete stages of data analysis also took place, save for the second and third stages, which occurred simultaneously. These steps are: (1) open coding; (2) focused coding; (3) coding using pre-established codes; and (4) cross-case analysis.

\subsubsection{Step 1: Open coding}

I began the first phase of data analysis alongside of data collection. I repeatedly reviewed interview transcripts, writing analytic memos in Dedoose to note emergent themes and to develop theories and hypotheses about the data, especially with regard to teachers' 
curricular conceptions, practices, and agency, and the influences on these areas. As I compared analytic memos to one another, they not only assisted in category formation, but functioned to focus interviews with other participants. For example, if I observed a theme across one or more interviews, this provided a more particular focus for subsequent data collection.

Once data collection was complete, I create a virtual case binder for each teacher, and I coded all interview transcripts, video data, and documents using open coding. Emerson et al. (2011) describe open coding as the reading of data line-by-line to determine emergent themes, rather than depending upon pre-established categories. I utilized open coding to analyze all data sources: surveys, interview transcripts, video transcripts and teacher artifacts.

\subsubsection{Step 2: Focused coding}

With data collection complete and basic themes noted, I engaged in focused coding, using fine-grained analysis in order to construct categories and subcategories for major themes, ideas, and/or issues that emerged during open coding. Glaser and Strauss (1967) note the strengths of emergent categories, stating that they "usually prove to be the most relevant and the best fitted to the data" (p. 37). I established these categories through the constant comparative method of analysis (Merriam, 2007), looking for patterns across data strands belonging to each individual case (surveys, interviews, video data, and teaching artifacts) and across cases. I also sought to connect these patterns to theory and previous research during focused coding, utilizing analytic memos to do so (Emerson et al., 2011). These analytic memos at first took the form of free writing in Dedoose, where various 
patterns appeared, as I wrote down possible theoretical and research connections. After this, the memos were edited and synthesized, as I considered all of the evident connections in relation to one another. Figure 3 demonstrates steps 1 and 2 of data analysis.

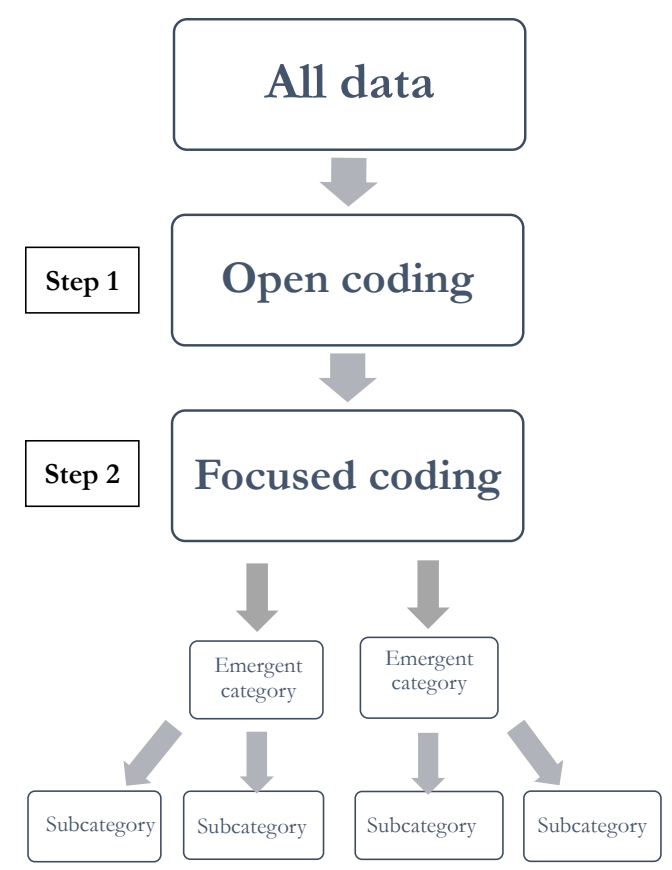

Figure 3. Steps 1 and 2 of Data Analysis

Some of the categories that emerged during open and focused coding were the influence of identity on participants' conceptions or practices, as well as the 'great quotes' category, which I used to code excerpts that stood out as especially representative of teachers' conceptions, practices, or their perceptions about the greatest influences on their conceptions or practices. The influences of past coworkers, past mentors, past resources, and past life experience emerged during focused coding as significant subcategories to the iterational dimension, which I then added to the coding scheme. Similarly, current coworkers, current mentors, current resources, and current community emerged as 
important practical-evaluative influences during focused coding and were thus added to the coding scheme. All other codes were pre-established, but I did reorganize them throughout the coding process. For example, I was originally planning to code influences as having occurred 'before the collaborative' or 'during/after the collaborative'; however, I discovered upon attempting to apply these codes to influences that they were superfluous, since the iterational, practical-evaluative, and projective dimensions inherently address the aspect of time.

\subsubsection{Step 3: Coding using pre-established codes}

Emerging themes in the data drove open and focused coding throughout data collection, but I simultaneously analyzed the data using pre-established codes that reflected the purpose of the research study and were rooted in the ecological model of agency (Campbell, 2012; Priestley et al., 2013). I analyzed units of data that were potentially meaningful as I moved between the data and the related research literature. A unit of data could be as small as a word used by a participant to describe a sentiment or phenomenon, or as large as several pages of an instructional plan or an interview transcript that related to a particular incident (Merriam, 2007). However, a unit of data had to be relevant to the study at hand, and "the smallest piece of information about something that [could] stand by itself" (Merriam, 2007, p. 180).

In this study, a curricular 'conception' referred to what a teacher considered to be true of teaching, learning, their context, students, or content, or their values and convictions regarding what they did in the classroom; it could be an ideal, a belief, a value, or a

conviction. A 'practice' referred to what a teacher allegedly did or planned to do in their 
classroom or school, according to what they stated in survey, interview and video transcripts, and what was apparent in their instructional plan. In this study, a unit of data was considered an 'influence' if a teacher noted its power in shaping what they thought or did in relation to their teaching. However, I also coded potential influences on teachers' conceptions or practices with the 'influences' application, so that I could explore which ecological dimensions were considered by teachers to be influential or insignificant to the shaping of their conceptions and practices.

Because in this study I was concerned with influences on the evolution of teacher participants' curricular conceptions, practices, and agency, I examined the data accordingly, with regard to (1) time; (2) ecological dimensions of influence at work before and during/after participation in the collaborative; (3) the alignment or misalignment of curriculum beliefs and practices before and during/after participation in the collaborative; and (4) whether teacher agency was structurally transformative or structurally reproductive in nature.

\subsubsection{Time}

After coding units of data as either 'conceptions,' 'practices,' or 'influences,' the excerpts considered to be conceptions and practices were demarcated according to the time to which they referred. Teachers were asked to reflect on their curricular conceptions and practices that took place both before and during/after their time in the collaborative. In order to understand which beliefs and practices were present before and during/after their participation in the collaborative, it was necessary to separate units of data into instances that 
referred to (1) conceptions and practices prior to the collaborative and (2) conceptions and practices during and after participation in the collaborative.

For example, if a teacher participant said, "Before this year, I followed the school's curriculum for seventh grade science," this unit of data was coded first as a "curricular practice,' and then as 'before the collaborative.' Units of data in which time was not explicitly specified were dependent upon their surrounding context in the survey, interview or video transcript in order to be coded, and units of data that referred to a participant's longstanding perspective or practice were coded as both 'before the collaborative' and 'during/after the collaborative.' For some participants, it became necessary to include a third category, which encompassed their curricular conceptions and/or practices that remained the same throughout their career.

\subsubsection{Ecological dimensions of influence}

Secondly, data coded as 'influences' were necessarily connected to a past or present belief or practice in the data. I did not delineate between influences that occurred before or during/after the collaborative, because the ecological dimensions of agency necessarily demarcate the past (iterational) from the present (practical-evaluative) and future (projective) influences. Thus, I coded influences according to the ecological dimension of agency that they represented in their influences on teacher participants' conceptions and practices (Priestley et al., 2013). I separated these units of data into instances of "iterational" influences, or teachers' life histories or professional histories, "practical-evaluative" influences, or the cultural, structural, and material contexts in which they live and work, and "projective" influences, or their orientations toward the future, both short-term and long- 
term. I also coded for the influences of personal and professional identity (a theme that emerged during open and focused coding) 3 and the influence of the collaborative.

This step of analysis was important, because it allowed for me to explore the nature of the influences that both the collaborative and other experiences had on teachers' agency. If a teacher participant mentioned in a unit of data the influence of their teacher preparation program, this unit of data was coded as 'iterational,' because it referred to the participant's history. If, on the other hand, a teacher described their current school context and its role in their current curriculum practices, the 'practical-evaluative' code was used. Teachers' future goals and orientations toward the future, when described as influences, were coded as 'projective.' When participants explicitly mentioned the collaborative as an influence on their conceptions or practices, the excerpt was coded as such. When participants mentioned their conceptions or practices being rooted in their convictions or character alone, I applied the 'identity' code. For excerpts that were coded with the ecological dimensions of influence, they were then more narrowly analyzed for the type of ecological influence that was represented. Figure 4 below shows all of the codes of influence that were applied in analysis of the data using the Dedoose application.

\footnotetext{
3 The other themes that emerged during open and focused coding fell under the iterational, practical-evaluative,
} and projective dimensions of influence. 


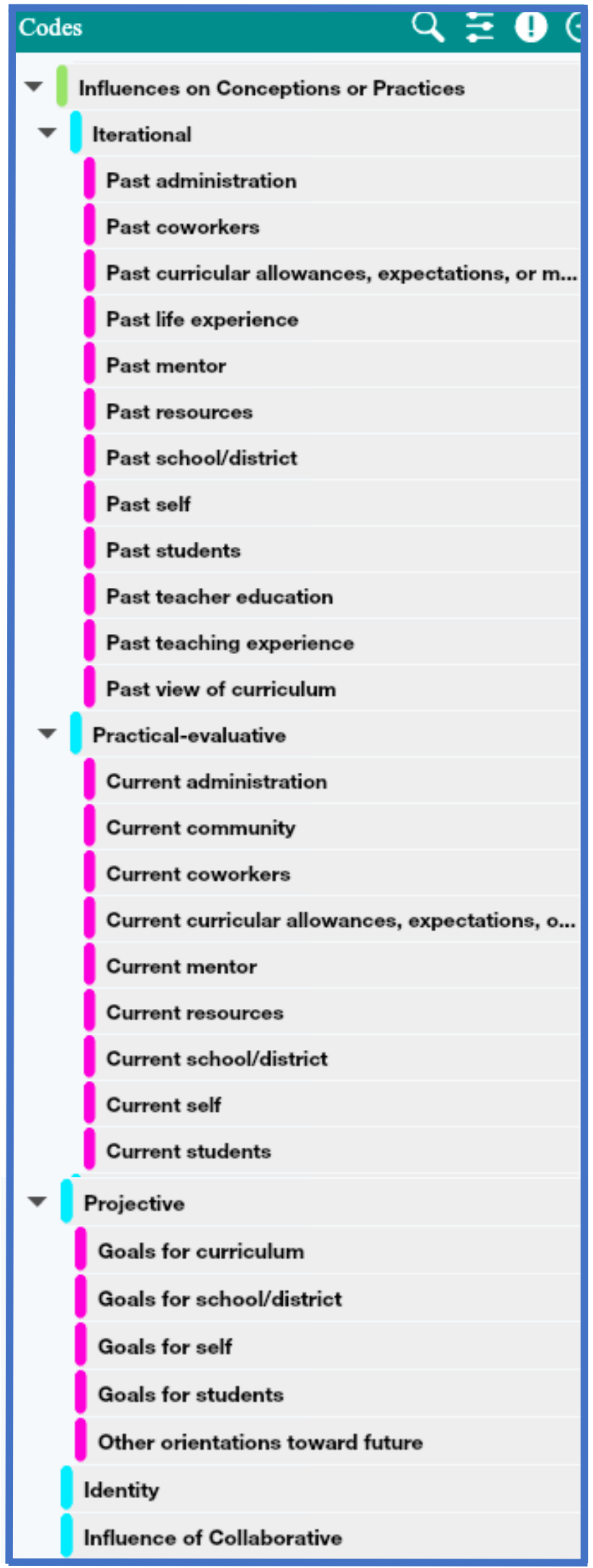

Figure 4. Coding Scheme: Influences on Teachers' Conceptions and Practices 


\subsubsection{Alignment or misalignment of conceptions and practices}

Next, units of data were demarcated according to alignment or misalignment of teachers' curricular beliefs and practices, as agency is defined as the ability to mobilize in the classroom that which is compatible with one's beliefs, values and convictions; in other words, it is alignment apparent through the enactment of one's beliefs in practice.

Because surveys, interviews, and video data elicited teachers' sharing about their curricular beliefs and practices both before and during/after their participation in the collaborative, this step allowed me to analyze the data with regard to growth and change in teachers' agency over time.

In order to discover alignments and misalignments that were apparent in teachers' perceptions of their beliefs and practices before the collaborative and during/after the collaborative, I downloaded all of the excerpts that referred to beliefs and practices before the collaborative and during and after the collaborative. For each participant, I analyzed these excerpts in a Word document, noting specific beliefs and values demonstrated through teachers' conceptions, and specific practices evidenced in the 'practices' excerpts. I noted specific conceptions by using statements beginning with "believes in" or "values," and active verbs when noting particular practices. For example, I might have further deduced an excerpt designated as a conception held by a teacher during or after the collaborative to show that he or she "values inquiry-based learning." Likewise, an excerpt designated as a practice enacted by a teacher before the collaborative might have been more clearly articulated as "used direct instruction."

After creating clearer descriptions for participants' curricular conceptions and practices by analyzing all of the related excerpts, I placed these beliefs and practices before 
the collaborative side by side in a table, and likewise placed their curricular conceptions and practices during and after the collaborative side by side in a table. I then looked for areas in which practices seem to derive from curricular conceptions, and areas in which practices seemed to oppose the teacher's asserted conceptions, using the constant comparative method to do so.

If, for example, a teacher believed in designing instruction to engage students and shared how they changed a unit in order to make it more engaging, these units of data were coded as 'aligned,' because the teacher's belief about their instruction was clearly translated into action. On the other hand, if a teacher stated a value for technology in learning but explicitly stated that they did not use technology in the classroom, the 'misaligned' code was applied. Teachers' innovative plans, designed during their participation in the collaborative, were considered to be 'practices,' and functioned to confirm or challenge teachers' stated perceptions about their curricular beliefs, further revealing alignments and misalignments between teachers' reported practices and actual practices.

Aligned conceptions and practices were understood as evidence of teachers' agency, while misaligned conceptions and practices represented a lack of agency.

\subsubsection{Structurally transformative or structurally reproductive agency}

Finally, I coded teachers' aligned conceptions and practices (or agency) as either structurally transformative or structurally reproductive in nature. If the aligned curricular conceptions and practices were expressive of innovation, and teachers created, adapted, or even subverted the prepackaged curriculum, I applied the 'structurally transformative agency' code. If, however, teachers' aligned conceptions and practices evidenced transmission of the 
prepackaged curriculum or maintenance of status quo structures and institutional mandates, the 'structurally reproductive agency' code was applied. Figure 5 displays the third step of data analysis.

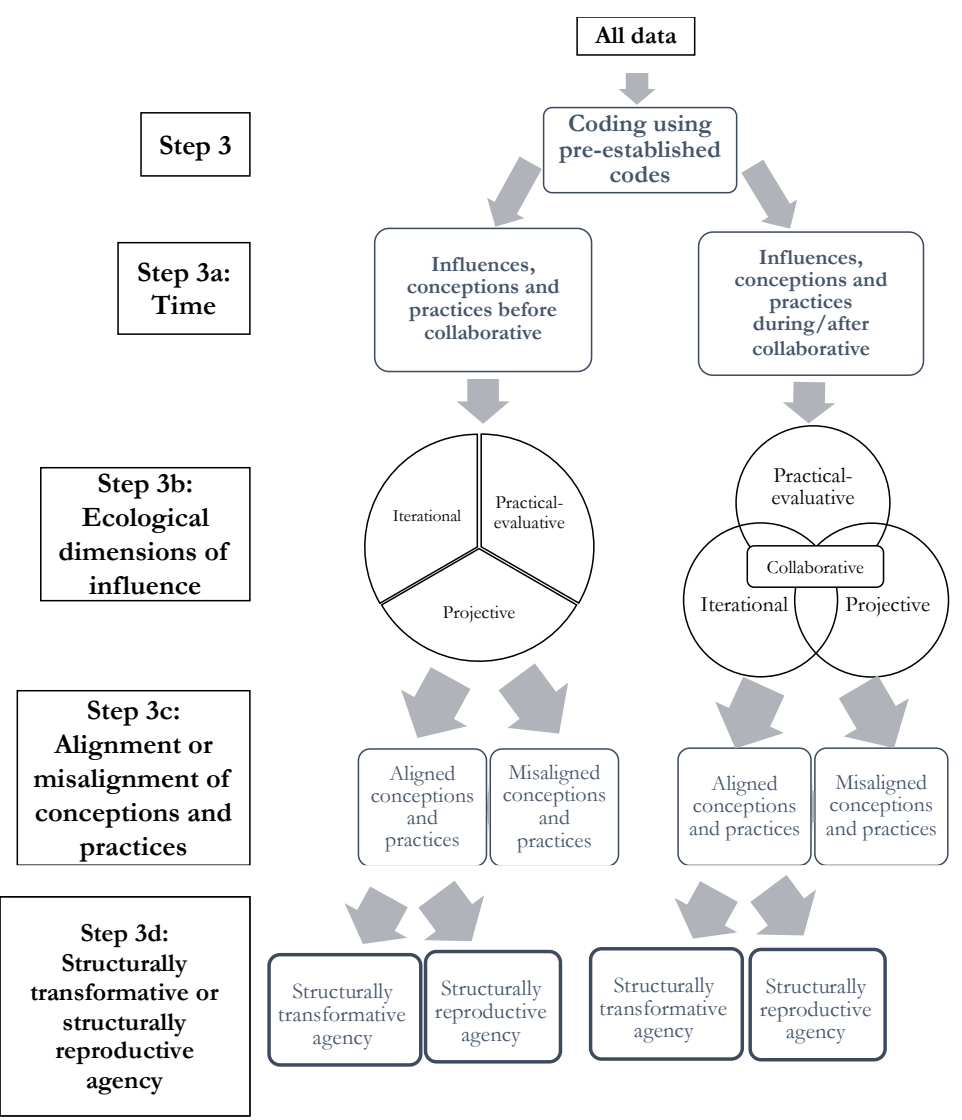

Figure 5. Step 3 of Data Analysis (Campbell, 2012; Hays, 1994; Priestley et al., 2013)

Step 3 of data analysis was perhaps the most important, as it allowed me to focus very particularly on answering the two research questions for each individual teacher, through which I sought to discover their conceptualizations about curriculum, their practices, and the influences that they perceived to have impacted their curricular conceptions and practices. In this stage of analysis, I examined the ecological influences on teachers' agency before the collaborative, and the influence of the collaborative, which 
served as a contact zone for various ecological dimensions of participants' lives and experiences. Figure 6 summarizes the way in which the ecological dimensions of teachers' experiences before their participation in the collaborative and their effect on teacher agency were examined, as well as the impact of the collaborative on teacher agency.

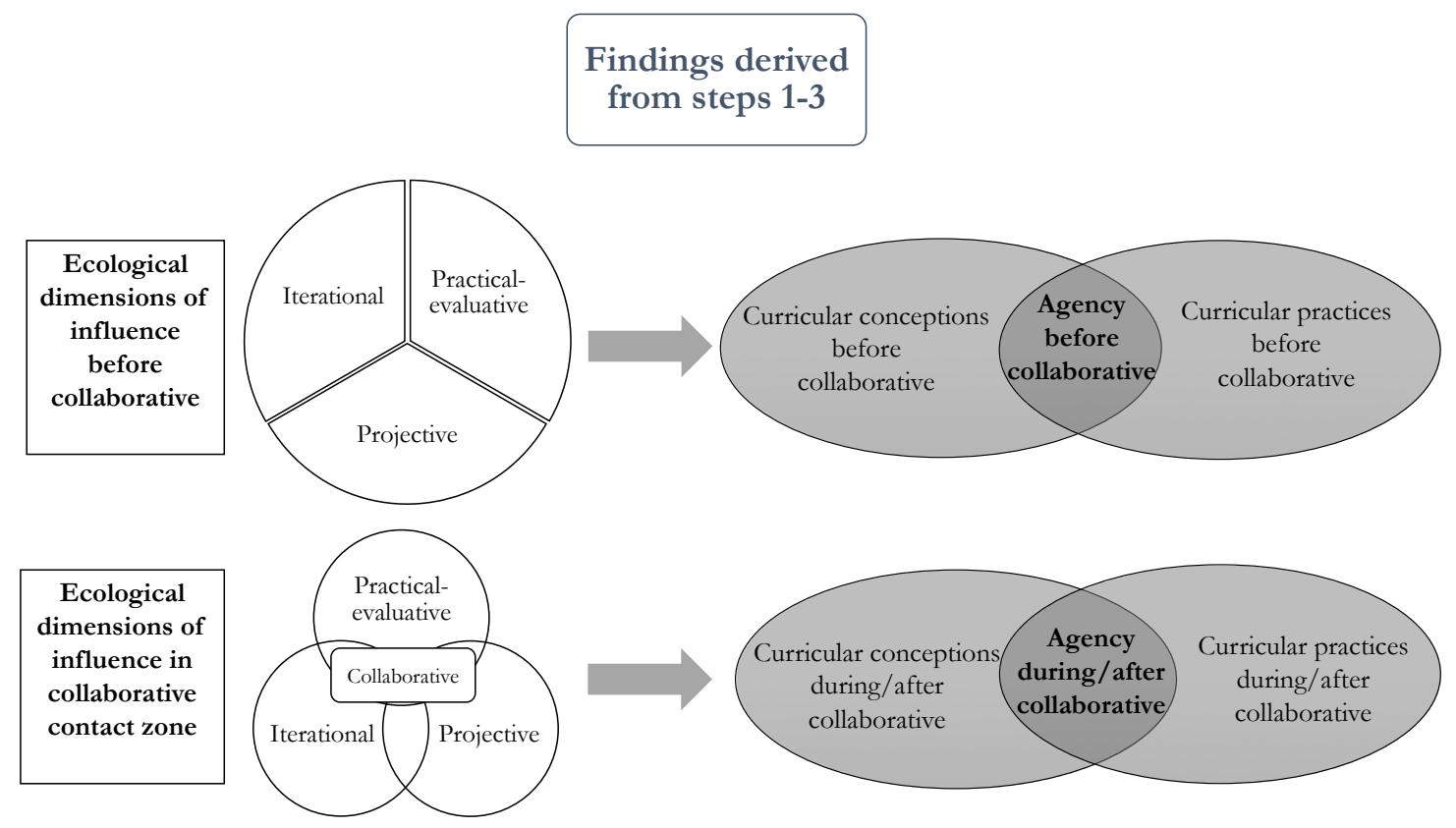

Figure 6. Influences and Teacher Agency Before and During/After the Collaborative Experience

Again, it is important to remember that while aligned beliefs and practices make for teacher agency, there is a difference between structurally reproductive teacher agency and structurally transformative teacher agency (Hays, 1994). Structurally transformative agency became evident in the coding process as I considered whether teachers' practices stemmed from their own beliefs, values, and convictions regarding teaching, learning, and their students, or if their practices were merely rooted in their affirmation of existing structures or school discourses. Structurally reproductive agency could like a teacher saying, "I believe that the prepackaged curriculum was designed to help students do well on standardized tests, so I use 
it;" while structurally transformative agency may evidence itself in a teacher saying, "I know that most of the other teachers teach the unit this way, but I decided to change it because my students weren't getting the material." Units of data that were aligned, but represented structurally reproductive agency, were treated separately from the rest of the data, though they were considered. Figure 7 shows the coding scheme that I developed to code data using the Dedoose application, save for the particular ecological influences shown in Figure 4, which fall under the iterational, practical-evaluative, and projective dimensions.

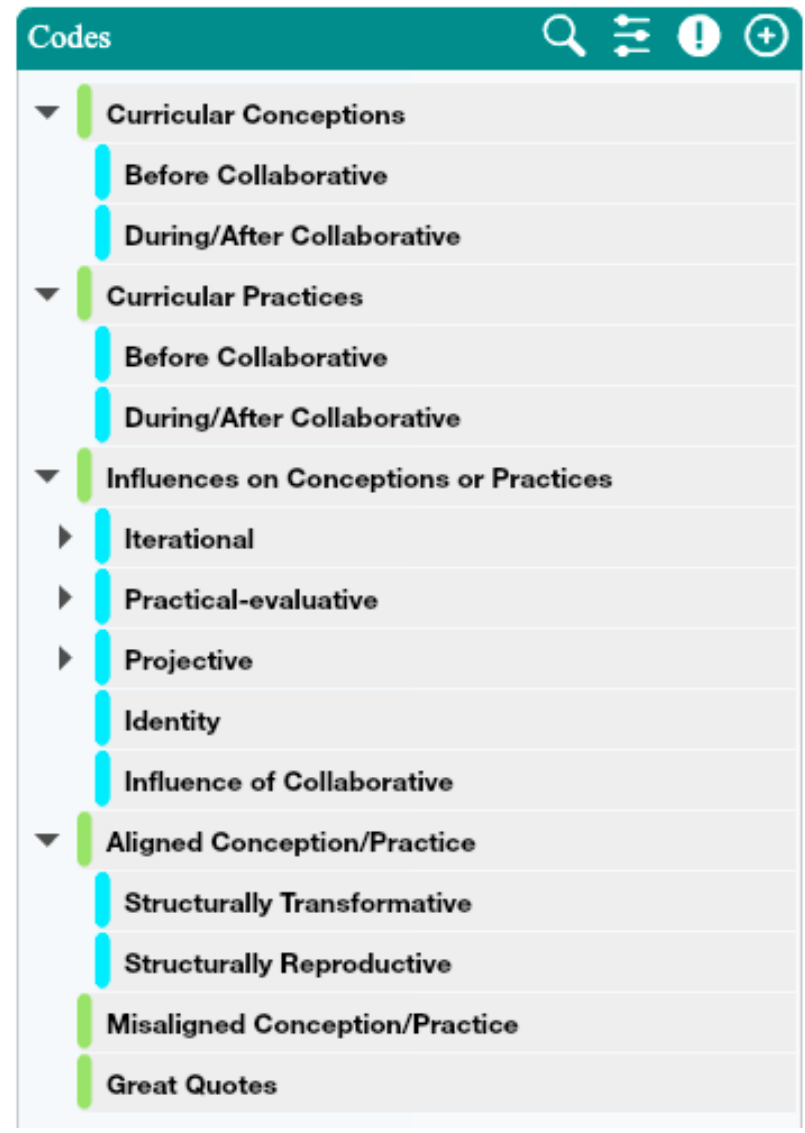

Figure 7. Coding Scheme Used for Steps 1-3 of Analysis 


\subsubsection{Step 4: Cross-case analysis}

Finally, I utilized cross-case analysis (Merriam, 2007; Stake, 2006; Yin, 1994) in order to present a unified description across cases (Merriam, 2007). I examined similarities and differences amongst cases, seeking to gain general understanding of teachers' perspectives and experiences in spite of the many complexities of individual cases. Merriam (2007) notes, “A qualitative, inductive, multicase study seeks to build abstractions across cases" (p. 195). The purpose of this study was not only to understand each individual participant's journey as a teacher agent, and the influences impacting their journey, but to come away with "a general explanation that fits each of the individual cases, even though the cases will vary in their details" (Yin, 1994, p. 112).

Miles and Huberman (1994) note the importance of examining the local dynamics and the complex configuration of processes within each case before exploring patterns of variables that transcend those cases. Cross-case analysis is the final phase of analysis because it is only once case data are individually and rigorously analyzed that they are suited to be analyzed in relationship to other cases. Because of local understanding built through open and focused coding for both emergent and pre-established codes in each case, I was able to develop more complex descriptions and more powerful explanations as I examined teachers' experiences and outcomes across several cases (Miles \& Huberman, 1994).

By examining the evolution of multiple teachers' curricular conceptions, practices, and agency alongside of one another, this stage of analysis produced theoretical insights regarding the types of ecological influences that teachers perceived to have the greatest supportive and constrictive effects on their agency. This stage of data analysis also allowed me to understand and describe the impact of the innovative professional collaborative on 
teachers' professional lives in a comprehensive way, as well as the other influences that seemed to play a role in teachers' achievement of agency. In this way, I was able to answer both research questions in relation to the group of participants as a whole, in addition to answering the questions for each individual case. Figure 8 illustrates this step of data analysis.

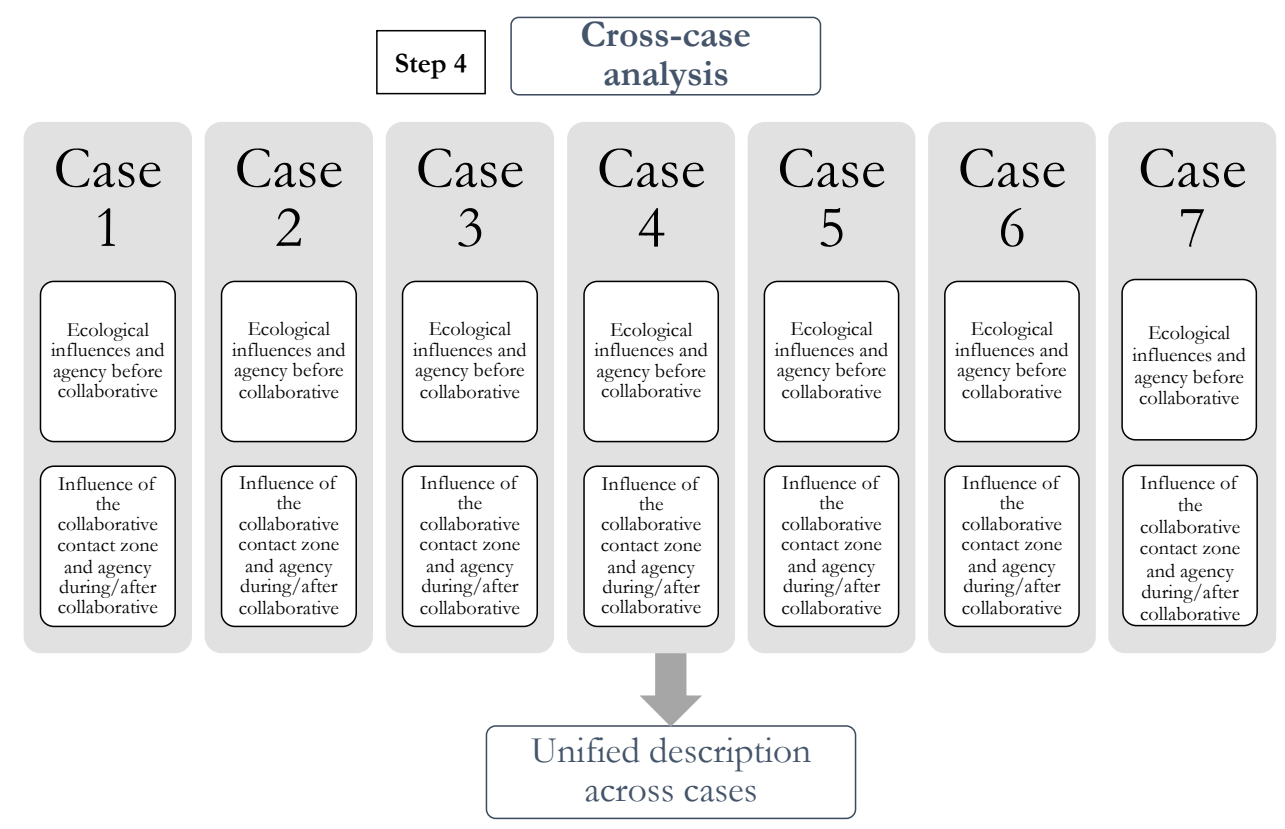

Figure 8. Step 4 of Data Analysis (Merriam, 2007)

\subsubsection{Establishing trustworthiness}

Merriam (2007) writes, "One of the assumptions underlying qualitative research is that reality is holistic, multidimensional, and ever-changing; it is not a single, fixed, objective phenomenon waiting to be discovered, observed, and measured as in quantitative research" (p. 202). There are several approaches that lead to systematic and rigorous qualitative research, which take into consideration the emergent and complex nature of reality as supported by the qualitative tradition. In this study, I employed triangulation, peer 
examination, and reflexivity in order to enhance the trustworthiness of this study (Merriam, 2007).

I utilized triangulation, which entailed both the collection and comparison of multiple sources of data, as well as multiple methods to confirm emerging findings (Merriam, 2007). By collecting multiple and varied data sources, I was able to draw out teacher participants' thinking as they engaged through various modes of communication, and to more clearly see agreements and discrepancies in the data. For example, by eliciting teachers' perspectives on their instructional plan in the interview and collecting and analyzing the actual plan, I was able to attend to alignments and misalignments in these sources. The various phases of data analysis also allowed for triangulation of the data, as open and focused coding, narrative analysis, and cross-case analysis shed light differently on the data, making for a more holistic understanding. Employing another strategy to increase the trustworthiness of this study, I shared my research with a fellow research colleague who were outside of the study in order to gain insight into the accuracy of my emerging findings (Merriam, 2007). This colleague's feedback challenged me to pay closer attention to how I was defining conceptions, practices, and influences, and the way in which I determined alignments and misalignments. Finally, I kept a researcher reflexive journal in order to reflect on my personal assumptions and stance as a researcher and to explain how these might have influenced my data collection and analysis (Fine, 1994; Salzman, 2002). For example, I used this space to reflect on instances found in the interview transcripts in which I exclaimed, "I want to be in your class!" These moments revealed to me the types of curricular practices of which I approved. The journal also provided me with a space in which to explore my own curricular conceptions and practices, and the ecological influences that have shaped and continue to shape my agency as a teacher. I utilized the researcher reflexive journal 
throughout data collection, maintaining it on a word document where I noted my personal assumptions and opinions about the collaborative and the impacts of various influences on teachers' curricular conceptions and practices. I also reflected on my own experiences regarding the evolution of my curricular conceptions, practices, and agency. In these ways, I ensured the trustworthiness of this qualitative research study.

\subsection{SUMMARY}

In this chapter, I have described and rationalized the procedures I used in this research study to explore the mediating factors that shaped teacher participants' curricular conceptions, practices, and agency over time. I incorporated several data sources and a variety of data analysis methods in order to enhance the trustworthiness of this study, and to provide a diverse set of lenses through which to view teachers' perceptions and experiences. For each approach to collection and analysis, I described the purposes and intentions for the steps taken.

\subsection{LIMITATIONS}

Findings from this research study must be considered in light of the limitations that existed in conducting it. While qualitative research is not guided or motivated by generalizations (Merriam, 2007), there are some important factors to bear in mind when considering the application of this study. First, the length of the study, being only a few months, may have caused its findings to be less robust than would be possible in a longer study. The participants took one survey, were interviewed once, created two video diaries, 
and sent a few artifacts related to their innovative instructional designs. While these methods yielded much data regarding the evolution of teachers' curricular conceptions, practices, and agency, much more could be learned in a study of greater length and depth. Second, data from this study were not collected via classroom observation, so it did not afford me the ability to see whether teachers mobilized the practices that they reported in the transcripts and instructional documents. In this way, teachers' agency could not be understood by examining teachers' actual practices, but only their reported practices. Finally, only one innovative professional collaborative was considered in this study. Selective sampling allowed for the close analysis of diverse teachers within the collaborative, but the contextdependency of this method prevents generalization of their experiences beyond the sociocultural context of the study. Studies involving a range of collaborative experiences may be helpful.

In the next two chapters, I present the findings from this study. In chapter four, I portray the seven teacher cases. To do this, I describe each participant's reported curricular conceptions and practices before and during and after the collaborative; note alignments and misalignments between their conceptions and practices; and characterize their exercise of agency as structurally transformative, structurally reproductive, or lacking altogether during the periods of time mentioned. In chapter five, I explore the perceptions of the teacher participants regarding the ecological influences on their conceptions and practices, and the impact of these influences on their ability to exercise agency at different times during their careers. I triangulate these findings with data from the teacher background surveys, interviews with both the teacher participants and the facilitator of the collaborative, video diaries, instructional designs provided by the teacher participants, as well as footage from the collaborative's Demo Day, seeking to understand which types of ecological influences best 
support teachers as curriculum innovators, including the influence of the innovative professional collaborative. 
In this chapter, I describe the seven teacher participants' reported curricular conceptions and instructional practices with regard to the time period before their participation in the collaborative, and during and after their participation in it, and in many cases, throughout the course of their career. Knowing what teachers considered to be true of teaching, learning, their context, students, and content (conceptions), as well as what they allegedly did or planned to do in their classroom (practices) were important here, as these revealed the nature of teachers' agency or lack of agency. Delineating between conceptions and practices occurring before and after teachers' participation in the collaborative, as well as those consistent throughout teachers' careers, allowed me to gain understanding as to when shifts in teachers' agency took place and what kind of a role the collaborative might have played in teachers' development of agency (or lack thereof). For some teachers, their early teaching career, rather than the time before the collaborative, was used as a measure of time, because there was no noted change in their conceptions and practices before and after their participation in the collaborative.

Next, I highlight whether their curricular conceptions aligned or misaligned with their reported practices during those periods of time, thus allowing me to determine whether and when they have exercised teacher agency during their careers, which I define as the ability to mobilize in the classroom that which is compatible with one's values, beliefs, and convictions, and which is influenced by personal, social, and societal factors. 
I then characterize each teacher participant's agency as either structurally reproductive in nature, structurally transformative, or lacking altogether during the periods of time mentioned. While a lack of agency is characterized by misalignment between teachers' curricular conceptions and practices, agency is reflective of alignment. However, structurally reproductive agency is expressed by the affirmation or reproduction of existing structures, such as prescriptive curricula, whereas structurally transformative agency is achieved by innovation, or in the creation of new structures (Hays, 1994).

\subsection{TAMI}

One of the original eight members of the collaborative during the year of its inception at Applewood High School, Tami served as a mentor to other teachers during the second year of the collaborative's existence. She has been teaching English/Language Arts for fourteen years, and has taught for three years at Applewood, having taught the prior eleven years at a nearby middle school. She has recently begun to teach Arts and Humanities, though English/Language Arts is still her primary focus.

Tami received a Bachelor of Arts degree in English from a university in the south and pursued her teacher education in Larborough at a private university, where she received her Master of Arts in Teaching by way of a traditional teacher education program.

Table 4. Tami's Conceptions and Practices Before and During/After the Collaborative4

\footnotetext{
4 In the tables treating teacher participants' conceptions and practices before and during/after the collaborative, the numbers in parentheses represent the number of code applications. Codes with only one application are not accompanied by a number.
} 


\begin{tabular}{|c|c|c|c|}
\hline $\begin{array}{l}\text { Conceptions } \\
\text { Before } \\
\text { Collaborative }\end{array}$ & $\begin{array}{c}\text { Practices Before } \\
\text { Collaborative }\end{array}$ & $\begin{array}{l}\text { Conceptions } \\
\text { During/After } \\
\text { Collaborative }\end{array}$ & $\begin{array}{c}\text { Practices During/After } \\
\text { Collaborative }\end{array}$ \\
\hline $\begin{array}{l}\text {-Believed that } \\
\text { prepackaged } \\
\text { curriculum } \\
\text { should be } \\
\text { followed closely } \\
\text { (2) } \\
\text {-Valued } \\
\text { teacher-led } \\
\text { instruction }\end{array}$ & $\begin{array}{l}\text {-Followed } \\
\text { prepackaged } \\
\text { curriculum (2) } \\
\text {-Enacted teacher- } \\
\text { led instruction (2) } \\
\text {-Controlled the } \\
\text { classroom (2) } \\
\text {-Chose all texts } \\
\text { herself } \\
\text {-Used 'sit and get' } \\
\text { instruction }\end{array}$ & $\begin{array}{l}\text {-Sees curriculum } \\
\text { as guide (6) } \\
\text {-Values student- } \\
\text { led instruction } \\
\text { (4) } \\
\text {-Values student } \\
\text { engagement (2) } \\
\text {-Values } \\
\text { relationship with } \\
\text { students } \\
\text {-Values 'going } \\
\text { beyond the } \\
\text { standards' } \\
\text {-Values } \\
\text { collaboration }\end{array}$ & $\begin{array}{l}\text {-Teaches to engage (8) } \\
\text {-Uses student-led instruction } \\
(7) \\
\text {-Collaborates with others (6) } \\
\text {-Uses standards-based } \\
\text { instruction (4) } \\
\text {-Offers student choice (4) } \\
\text {-Teaches sports literacy (4) } \\
\text {-Promotes inquiry-based } \\
\text { learning (4) } \\
\text {-Facilitates instruction (3) } \\
\text {-Aligns instruction with PLC } \\
\text { (2) } \\
\text {-Uses real world application (2) } \\
\text {-Promotes student } \\
\text { collaboration } \\
\text {-Serves as a resource } \\
\text { development } \\
\text {-Uses project-based learning }\end{array}$ \\
\hline
\end{tabular}

According to Tami, her vision for her instruction and students that guide how and what she teaches is 5 that students would develop an intrinsic desire to learn, that the

\footnotetext{
${ }^{5}$ I use present tense to refer to conceptions and practices that continue, as much of this chapter seeks to delineate between past and current beliefs and practices.
} 
instruction would engage them, and that curiosity would be sparked within them, encouraging greater agency in them. In order to reach this goal, Tami uses the theme of sports whenever possible, seeking to engage her students in the texts they are reading; in fact, during her first year in the collaborative, she designed a whole course surrounding sports literacy, which served as her innovative instructional design. She utilizes whole class instruction as a brief foundation for instruction, while students spend the majority of their time engaging in small group work and project-based learning. In the teacher background survey Tami stated, "My class is designed specifically for students who either have not benchmarked on the ACT or who have a history of being disengaged in the learning process. The curriculum is designed to allow for more student ownership (agency) in the learning process."

\subsubsection{Tami's curricular conceptions and practices before the collaborative}

In her early years as a teacher, Tami's classroom practices followed her beliefs, values, and convictions, and not surprisingly, in one of the video diaries, Tami noted, "[T]n the past, most of my lessons have been student-, er, teacher- [corrects] led, sit and get type of lessons, with me giving them specific things to read, specific expectations." She described her previous teaching self as a "control freak."

Tami does not view her following of the district's curricular suggestions and resources in a completely negative light, however. In the interview, she noted that it was "great to have their suggestions, and have that to follow," and that it was "wonderful" to get a lot of her resources and short story ideas from the district. At this point in her career, she 
was at home in utilizing the prepackaged curriculum, and this aligned well with her belief that this was what she was supposed to be doing.

\subsubsection{Tami's curricular conceptions and practices during and after the collaborative}

Tami reported in one of the video diaries, "I do believe that my concept of curriculum and my role in it have changed tremendously in the last two years...we're always taught so much to follow the curriculum, and people often feel they can't add things into the curriculum." For many years, Tami believed that teacher-led instruction was the only option, noting in the interview that during her first year in the collaborative, she and her team laughed as they reflected on the way that they had "spent so many years controlling the room and making sure everyone was doing exactly this and exactly that and constantly feeling like we...had to be controlling at all times."

Tami describes the shift in thinking that took place as a movement from feeling required to teach only the standards in the way that they are suggested to be taught, to "go[ing] beyond the standards" in order to help students to cultivate the knowledge and skills deemed important in the state standards, but to do this in such a way that engages and empowers students to be agents in their learning.

Tami has come to see herself as a resource in her classroom, and no longer a "control freak"; she has also come to see curriculum as a guide and an outline, and no longer a mandate to be enacted in one particular way. She now believes that students need much more than to be spoon-fed information; they need to discover "that passion for learning and for questioning," Tami notes. "To me, that's the best thing you can have in a curriculum, is students that are authentically engaged in it. They want to continue with the learning. They 
want to put forth the effort and put forth to do extra work," she said. Tami values student voice, student choice, and relationship with her students, all of which she feels are keys to their intrinsic motivation, empowerment, and lasting learning.

\subsubsection{Tami's exercise of agency}

Table 5 demonstrates alignment between Tami’s curricular conceptions and practices, both before her participation in the collaborative and during and after her participation in it. It is clear that Tami exercised agency before her collaborative years; however, this agency was structurally reproductive in nature. She believed she was beholden to prepackaged curricula, and that is therefore what she enacted, not going beyond the expectations and mandates of her school or district, but rather, conforming to them.

This contrasts with the structurally transformative agency that she has exercised in more recent years. Based on her convictions about the flexibility of curriculum, and the need for students to be empowered, engaged, and known, she has designed sports literacy curriculum that is outside of the box of traditionally-taught literature, and has loosened the reins of her control, allowing students to be led by their questions and interests and the real

world around them. Not only this, but Tami has transformed from one who thought she had nothing to share with the teachers around her, to one who has found a voice to mentor and encourage others through programs like the collaborative, in-school mentorship, and professional development teaching opportunities. She is united with her fellow PLC members and values the standards, but feels that there should be flexibility in the way the standards are taught. She pursues the path that she believes will lead to greater student 
agency and long-term engagement and learning, and this path is not set forth by the prepackaged curriculum.

Table 5. Tami's Aligned and Misaligned Conceptions and Practices Before and During/After the Collaborative

\begin{tabular}{|c|c|c|c|c|}
\hline \multirow[t]{2}{*}{$\begin{array}{l}\text { Time } \\
\text { Period }\end{array}$} & \multicolumn{2}{|c|}{ Aligned Conceptions and Practices } & \multicolumn{2}{|c|}{$\begin{array}{c}\text { Misaligned Conceptions and } \\
\text { Practices }\end{array}$} \\
\hline & Conceptions & Practices & Conceptions & Practices \\
\hline 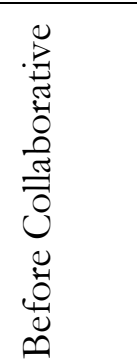 & $\begin{array}{l}\text { Valued teacher-led } \\
\text { instruction; Believed } \\
\text { that prepackaged } \\
\text { curricula should be } \\
\text { followed closely. }\end{array}$ & $\begin{array}{l}\text { Followed prepackaged } \\
\text { curricula; Enacted } \\
\text { teacher-led instruction; } \\
\text { Controlled the } \\
\text { classroom; Chose all } \\
\text { texts herself; Used 'sit } \\
\text { and get' instruction }\end{array}$ & & \\
\hline \multirow{5}{*}{ 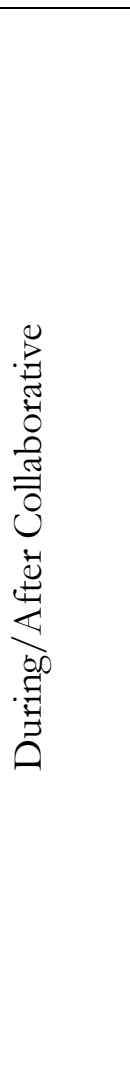 } & $\begin{array}{l}\text { Sees curriculum as a } \\
\text { guide, not a rule }\end{array}$ & $\begin{array}{l}\text { Uses standards-based } \\
\text { instruction; Aligns } \\
\text { instruction with PLC }\end{array}$ & & \\
\hline & $\begin{array}{l}\text { Values student-led } \\
\text { instruction; Values } \\
\text { student engagement }\end{array}$ & $\begin{array}{l}\text { Uses student-led } \\
\text { instruction; Teaches to } \\
\text { engage; Promotes } \\
\text { inquiry-based learning; } \\
\text { Offers student choice; } \\
\text { Facilitates instruction; } \\
\text { Serves as a resource; } \\
\text { Teaches sports literacy; } \\
\text { Uses real world } \\
\text { application; Uses project- } \\
\text { based learning }\end{array}$ & & \\
\hline & $\begin{array}{l}\text { Values relationship } \\
\text { with students }\end{array}$ & $\begin{array}{l}\text { Facilitates instruction; } \\
\text { Serves as a resource }\end{array}$ & & \\
\hline & Values collaboration & Collaborates with others & & \\
\hline & $\begin{array}{l}\text { Values 'going } \\
\text { beyond the } \\
\text { standards' }\end{array}$ & $\begin{array}{l}\text { Teaches sports literacy; } \\
\text { Uses project-based } \\
\text { learning; Leads } \\
\text { professional } \\
\text { development }\end{array}$ & & \\
\hline
\end{tabular}

\subsubsection{Artifactual evidence of Tami's agency}


The alignment between Tami's curricular conceptions and practices is apparent in the data from the interview, video diaries, and teacher background survey. Alignment is also evident in the artifacts that she provided during the study, which consisted of 1) a final project description from a 2018 Winter Olympics Unit that she designed for her Sports Literacy course during her first year in the collaborative, and 2) a book-based unit that she designed in collaboration with another teacher.

In the 2018 Winter Olympics Unit project description, students were asked to work in groups to track a live sport during the Olympics, and to provide an in-depth description of the sport and the field of play, the history of the sport, a video clip of the sport being played, two or three unusual facts about the sport, the countries participating in the sport that year, and a complete list of sources of information. Students were to pay close attention, as well, to both "verbal and visual aspects" of their presentations, seeking to present clearly, with appropriate tone, eye contact, body language, and visuals to support their presentations.

In this particular assignment, alignment between Tami's beliefs and practices is apparent in that students were expected to track the live sporting events in the Winter Olympics in order to complete their final project. This project relates clearly to Tami's value for student engagement and collaboration, and is demonstrative of her reported practices of sports literacy, student choice, real world application, and project-based learning. She created this unit herself, straying from prepackaged curricula in order to reach her students, thus achieving structurally transformative agency.

The unit that Tami designed in collaboration with another teacher is based on a book, as shared above, and is replete with examples of Tami's aligned conceptions and practices. The book consists of a series of firsthand accounts and tells the story of almost fifty years of an annual Larborough basketball event and the community building that has 
taken place during the event. This theme, in and of itself, evidences Tami's value for student engagement and sports literacy.

In several ways, Tami's creation of this unit itself evidences alignment between her beliefs and practices. The unit guide is meant to be used by other teachers in the city, thus demonstrating Tami's newfound passion for mentoring others and to lead professional development. Her collaboration with another teacher in the creation of this unit reflects her belief that in working together, teachers are able to grow. Tami's act of designing this curriculum also reflects her belief that curriculum is a guide, not a mandate, and that she is free to reach her students in whatever way she sees fit, as long as her instruction is standards-based.

In alignment with her belief that instruction should be standards-based, Tami and her colleague clearly emphasize the state standards in their expectations of students, as they ask students to annotate memoirs, to build arguments based on textual references, to complete writing, listening, and comparative tasks, to take note of tone, to make intertextual connections, and to research and present findings to the class.

Students are also given choice during this unit, as they are asked to select one topic in the book and to read at least twenty pages about that topic or aspect of the book, becoming experts in that area, and creating a visual display that highlights the most important information about their topic. The unit plan specifically instructs the teacher, "Try not to be too specific so students can explore and investigate freely." In another place, an activity called "Athlete Activists" is described, which students can complete in a small group or individually; students can also choose to present their findings verbally, in writing, or through a podcast. Also demonstrating student choice, the materials listed for the unit 
includes "student self-selected materials," showing clearly that students are to be the take the lead in their learning and investigation.

Finally, the unit curriculum encourages the teacher to invite a local community leader to speak to their students. "Help students prepare questions for the activist prior to the visit to ensure they are actively engaged with the speaker," the instructions read. This section of the unit, as well as the inclusion of so many materials that are locally related, reveal Tami's value for real world application of their learning.

Tami's exercise of structurally reproductive agency in the time during and after her participation in the collaborative is apparent in both her reported conceptions and practices, as well as the artifacts she provided, while structurally reproductive agency was characteristic of her teaching life before her participation in the collaborative.

\subsection{KELLEN}

Kellen was another of the original members of the collaborative during its first year at Applewood High School, and, like Tami, served as a mentor to other teachers in the collaborative during the second year. She has been teaching in secondary education for nine years, both in middle school and in high school, where she has taught Integrated Science, Biology, Human Anatomy and Physiology, and Environmental Science/Ecology, as well as

AP Environmental Science. Before her career in secondary education, Kellen spent five years as a teaching assistant in a large midwestern university, where she taught Introduction to Zoology Laboratory, Invertebrate Zoology Laboratory, and Comparative Vertebrate Anatomy. 
After having taught in higher education, Kellen pursued her Master of Arts in Teaching at a large public university in the same city where she now teaches. She completed the alternative certification program while working full time.

Kellen shared in the teacher background survey that her vision and goals for instruction change depending on the goals of the courses she is teaching. She noted that when she was teaching in the laboratory context in higher education, her goal was to be as consistent as possible with the other teaching assistants with the content and delivery. Today, teaching in high school, her goal is "to communicate about science in a way that makes students interested and curious to know more, while also covering content required by standards."

Kellen noted that in order to engage students, she has moved away from lecture in the past three years, seeking instead to "use experiences to help students understand content." For the Environmental Science class Kellen created during time in the collaborative, she described the curriculum as a "problem- and place-based curriculum using sustainable goals for the city of Larborough, and Larborough's urban tree canopy assessment as a starting point for discussing relevant environmental issues." In pursuing this curriculum, Kellen and her students work with community professionals, frequent the high school's oncampus forest, apply for grants in order to solve problems on campus or in the city, and present at various summits and expositions in and around the city.

Table 6. Kellen's Conceptions and Practices Before and During/After the Collaborative

\begin{tabular}{|c|c|c|c|}
\hline $\begin{array}{c}\text { Conceptions } \\
\text { Before } \\
\text { Collaborative }\end{array}$ & $\begin{array}{c}\text { Practices Before } \\
\text { Collaborative }\end{array}$ & $\begin{array}{l}\text { Conceptions } \\
\text { During/After } \\
\text { Collaborative }\end{array}$ & $\begin{array}{c}\text { Practices During/After } \\
\text { Collaborative }\end{array}$ \\
\hline
\end{tabular}




\begin{tabular}{|c|c|c|c|}
\hline $\begin{array}{l}\text {-Valued teacher } \\
\text { freedom (2) } \\
\text {-Valued hands-on } \\
\text { learning (2) } \\
\text {-Did not value } \\
\text { prepackaged } \\
\text { curricula } \\
\text {-Did not value } \\
\text { teacher-led } \\
\text { instruction } \\
\text {-Did not want to } \\
\text { be told how to } \\
\text { teach } \\
\text {-Did not value 'sit } \\
\text { and get' } \\
\text { instruction } \\
\text { (passive learning) } \\
\text {-Valued student- } \\
\text { led instruction } \\
\text {-Valued teacher } \\
\text { innovation }\end{array}$ & $\begin{array}{l}\text {-Used sit and get } \\
\text { instruction/Was } \\
\text { the giver of } \\
\text { knowledge (8) } \\
\text {-Began } \\
\text { experimenting with } \\
\text { projects/innovating } \\
\text { (6) } \\
\text {-Followed other } \\
\text { teachers (5) } \\
\text {-Used prepackaged } \\
\text { curriculum/did not } \\
\text { design instruction } \\
\text { (4) } \\
\text {-Began facilitating } \\
\text { in certain classes (2) } \\
\text {-Lectured } \\
\text {-Did lab-based } \\
\text { direct instruction } \\
\text { - Did not know } \\
\text { what she was } \\
\text { doing" }\end{array}$ & 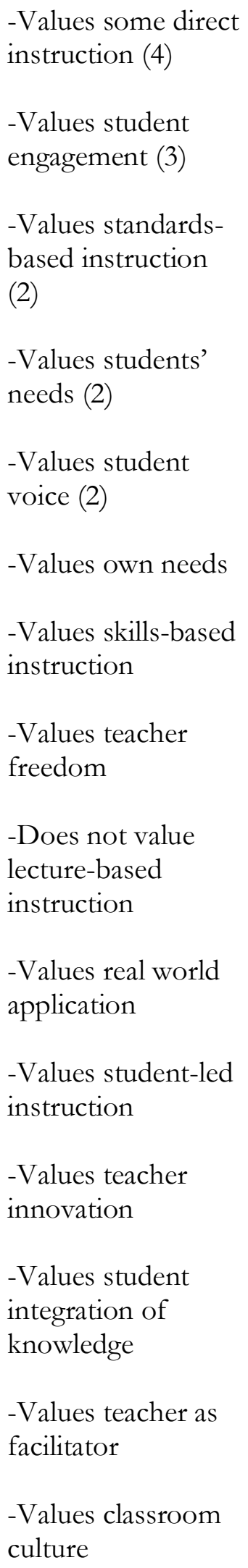 & $\begin{array}{l}\text {-Designs curriculum (13) } \\
\text {-Uses real world } \\
\text { application (10) } \\
\text {-Uses student-led } \\
\text { instruction (10) } \\
\text {-Uses problem-based } \\
\text { learning (8) } \\
\text {-Uses place-based learning } \\
\text { (7) } \\
\text {-Uses less lecture; Does } \\
\text { not use sit and get } \\
\text { instruction (6) } \\
\text {-Teaches to engage (6) } \\
\text {-Uses project-based } \\
\text { learning (5) } \\
\text {-Promotes student } \\
\text { collaboration (5) } \\
\text {-Facilitates learning (5) } \\
\text { students } \\
\text {-Uffers student choice (4) } \\
\text { knowledge at times (3) } \\
\text {-Advocates for change } \\
\text { Promotes community } \\
\text { collaboration (4) } \\
\text {-Uses standards-based } \\
\text { instruction (3) } \\
\text { feedback (3) } \\
\text { - }\end{array}$ \\
\hline
\end{tabular}




\begin{tabular}{|c|c|c|c|}
\hline & & $\begin{array}{l}\text {-Believes she must } \\
\text { give common } \\
\text { assessments } \\
\text {-Values } \\
\text { collaboration } \\
\text {-Values human- } \\
\text { centered design }\end{array}$ & $\begin{array}{l}\text {-Hosted an exposition } \\
\text {-Uses atypical resources } \\
\text {-Uses typical resources in } \\
\text { atypical ways } \\
\text {-Uses human-centered } \\
\text { design }\end{array}$ \\
\hline
\end{tabular}

4.2.1 Kellen's curricular conceptions and practices before the collaborative

According to Kellen, throughout her career, she has never valued sole use of the prepackaged curriculum and teacher-led instruction. Describing a colleague with whom she worked at her first high school job, Kellen shared in the interview, "He's lovely, but he's very, 'Here’s your book, here's your chapter, here’s your lecture, here’s your questions, here's your quiz, your test, and we'll do a lab every once in a while,' rinse and repeat. And I didn't like that already." While Kellen did not like his direct style, or 'sit and get,' as she and her colleagues at Applewood often call it, she continued, "So, I did that for the most part, because I was new to the profession." Elsewhere, she noted that she "relied on lecture to provide students with instruction" and that she "didn't do any design" in the beginning of her career.

"I had always been a teacher who did not like being told how to teach. Tell me what to teach all day. Give me the standards, that's fine. Don't tell me how to teach it," Kellen stated. In spite of her career-long value for individual freedom to teach the way that she felt best, Kellen consistently noted that during the first several years of her career, she followed other teachers in their enactment of curriculum, both because she did not know how to 
deviate from their practice, and because she felt obligated to teach as they taught. "I found it very uncomfortable to take 'canned lessons,' or lessons from a binder that somebody else wrote and teach it. It's very easy to do that, but it felt inauthentic," she noted in a video diary. Yet, time and time again, in her early days as a teacher, she did use the lessons of others. "I felt compelled to teach like other teachers," she said.

The mismatch between Kellen's values and her actions in the beginning of her career is an evident source of shame for her. In the interview, she noted, “I don't know why I was paid. Like, I feel like I was a really bad teacher. I felt like I didn't know what I was doing." That Kellen's ideals did not mesh with the enactment of her instruction seems to have been a driving force in her changing practice, however. Kellen now senses a pattern in her practice throughout her career: that in whatever class she teaches, the first year consists of more direct instruction, and after she comes to know the content curriculum, she "goes rogue."

Kellen used the term 'rogue' seven times during data collection to describe herself and her changing practice. In both the interview and the video diaries, Kellen described the phenomenon in her career of her classes beginning with 'sit and get' and lecture, and transforming into classes that involved more project-based learning and student-driven instruction. She illustrated this by speaking of her first couple of years at Applewood High School:

So, my first year, I taught Freshman Science, and it was very 'sit and get' and number-crunching, 'cause it's physics-based for the most part, and then at the end of the course I started to go rogue. Second year, I taught Biology, and it was a trimester class, or two trimester class, so first trimester, I taught the first chunk of the class, second trimester I was like 'Mm? [makes a questioning expression] I didn't like how that was taught, I'm goin' rogue.' So it seems to happen pretty quickly with me. [laughs]...'cause I don't do 'sit and get.'

Interestingly, Kellen's transformation into a teacher who “[doesn't] do 'sit and get”" is very evidently a continual process. Regarding her Biology class two years ago, she noted: 
[T] he way that we taught evolution was very sit and get, here are all the different types of evidence that I'm telling you about, or giving you this dry reading about, that's not relevant because it's from a book that was probably written when you were two. So, second trimester ... when I basically repeated that class, that was one chunk of content that was like, 'I know how to teach this way better than this'? And so I did a group project and I still have some of their writing from that class because it was so dramatic, the difference between [students' work before the curricular change and after].

Between the first and second trimesters that year, Kellen's Biology class began to transform.

Even as recently as the last school year, Kellen's Anatomy class was more

characteristic of the type of instruction she disdains. She shared what it was like:

[1] was a mad dash to get stuff done, and it was mostly 'sit and get'. So, last year, from August to December [during the] first semester, I taught it that way I'd always taught it, and I think there was some, I don't know, ivory-towerness of that class? Like 'I know all this information therefore you should know it,' because that's like, kind of how science can be? [laughs] So like, I was the end all be all of anatomy knowledge. I'm like 'I know all this stuff and it could be way harder in college and I'm going easy on you even though this is really rippin' hard, and I'm giving you this sixty-question test 'cause I'm a punk and I want to see what you can remember.' Like, why was I doing that?

Kellen also shared her plans to change the class for the next school year, should she teach it again.

Kellen sees herself as moving from "the giver of knowledge to a facilitator." In some classes, she feels that she has always been a facilitator, while in others, she feels that she has gradually moved toward becoming a facilitator, or even moved back and forth between direct instruction and facilitation of learning, acting as a 'hybrid' instructor.

Table 7. Kellen's Consistent Conceptions Throughout Her Career

\begin{tabular}{|l|l|}
\hline \multicolumn{1}{|c|}{ Before Collaborative } & \multicolumn{1}{c|}{ During/After Collaborative } \\
\hline Valued teacher freedom & Values teacher freedom \\
\hline $\begin{array}{l}\text { Did not value 'sit and get' instruction; Did } \\
\text { not value teacher-led instruction }\end{array}$ & Does not value lecture-based instruction \\
\hline
\end{tabular}




\begin{tabular}{|l|l|}
\hline Valued hands-on learning & Values real world application \\
\hline Valued student-led instruction & Values student-led instruction \\
\hline Valued teacher innovation & Values teacher innovation \\
\hline
\end{tabular}

4.2.2 Kellen's curricular conceptions and practices during and after the collaborative

As shown in Table 7 above, Kellen's curricular conceptions have remained more or less consistent throughout her career. The data show that since the beginning of her career, she has valued teacher freedom and innovation and has not valued 'sit and get' teacher-led instruction, but rather hands-on and student-led instruction. However, her practices have come to reflect these long-held beliefs, values and convictions more so in recent years.

In contrast to her statement about her early days as a high school teacher when she did what her co-teacher did in spite of her differing ideals, Kellen described the recent process of designing her Environmental Science course, saying, "I'm pretty consistent with not wanting to teach with direct instruction. I just don't like it. It's not enjoyable, kids don't enjoy it, it takes too much time sometimes out of class, that you could be doing things? And I value doing things more than direct instruction. So, I did not use direct instruction very much in designing my class. And it was great."

There is an evident difference between her early teaching self and her more recent identity: the former followed others into instruction that she did not feel was best, while the latter makes decisions based on her own values and convictions. These values and convictions have led Kellen into designing courses from scratch that are project-based, place-based, and problem-based; being open to student feedback, failure, and change; inviting more student collaboration, movement, and outdoor exploration; initiating field trips 
and community involvement; and pursuing various grants, awards, and professional opportunities alongside her students.

Table 8. Kellen's Aligned and Misaligned Conceptions and Practices Before and During/After the Collaborative

\begin{tabular}{|c|c|c|c|c|}
\hline \multirow[t]{2}{*}{$\begin{array}{l}\text { Time } \\
\text { Period }\end{array}$} & \multicolumn{2}{|c|}{ Aligned Conceptions and Practices } & \multicolumn{2}{|c|}{$\begin{array}{c}\text { Misaligned Conceptions and } \\
\text { Practices }\end{array}$} \\
\hline & Conceptions & Practices & Conceptions & Practices \\
\hline \multirow{3}{*}{ 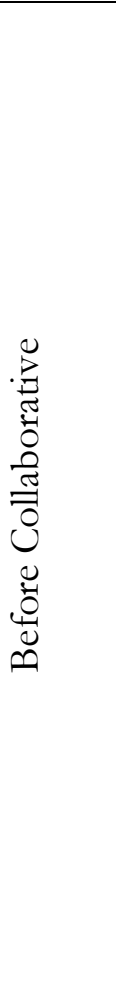 } & $\begin{array}{l}\text { Valued teacher } \\
\text { innovation; Did } \\
\text { not value } \\
\text { prepackaged } \\
\text { curricula; Did not } \\
\text { want to be told } \\
\text { how to teach }\end{array}$ & $\begin{array}{l}\text { Began experimenting } \\
\text { with } \\
\text { projects/innovating; } \\
\text { Began facilitating in } \\
\text { certain classes }\end{array}$ & $\begin{array}{l}\text { Valued hands- } \\
\text { on learning; } \\
\text { Did not value } \\
\text { sit and get } \\
\text { instruction; } \\
\text { Did not value } \\
\text { teacher-led } \\
\text { instruction; } \\
\text { Valued } \\
\text { student-led } \\
\text { instruction }\end{array}$ & $\begin{array}{l}\text { Lectured; Used } \\
\text { 'sit and get' } \\
\text { instruction; } \\
\text { Was the giver } \\
\text { of knowledge; } \\
\text { Did lab-based } \\
\text { direct } \\
\text { instruction }\end{array}$ \\
\hline & & & $\begin{array}{l}\text { Did not value } \\
\text { prepackaged } \\
\text { curricula }\end{array}$ & $\begin{array}{l}\text { Used } \\
\text { prepackaged } \\
\text { curriculum/Did } \\
\text { not design } \\
\text { instruction } \\
\end{array}$ \\
\hline & & & $\begin{array}{l}\text { Valued teacher } \\
\text { innovation; } \\
\text { Did not want } \\
\text { to be told how } \\
\text { to teach }\end{array}$ & $\begin{array}{l}\text { Followed other } \\
\text { teachers }\end{array}$ \\
\hline
\end{tabular}

\begin{tabular}{|c|c|c|}
\hline 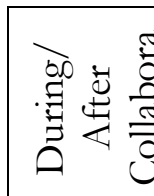 & $\begin{array}{l}\text { Values standards- } \\
\text { based instruction; } \\
\text { Values skills- } \\
\text { based instruction }\end{array}$ & $\begin{array}{l}\text { Standards-based } \\
\text { instruction }\end{array}$ \\
\hline
\end{tabular}




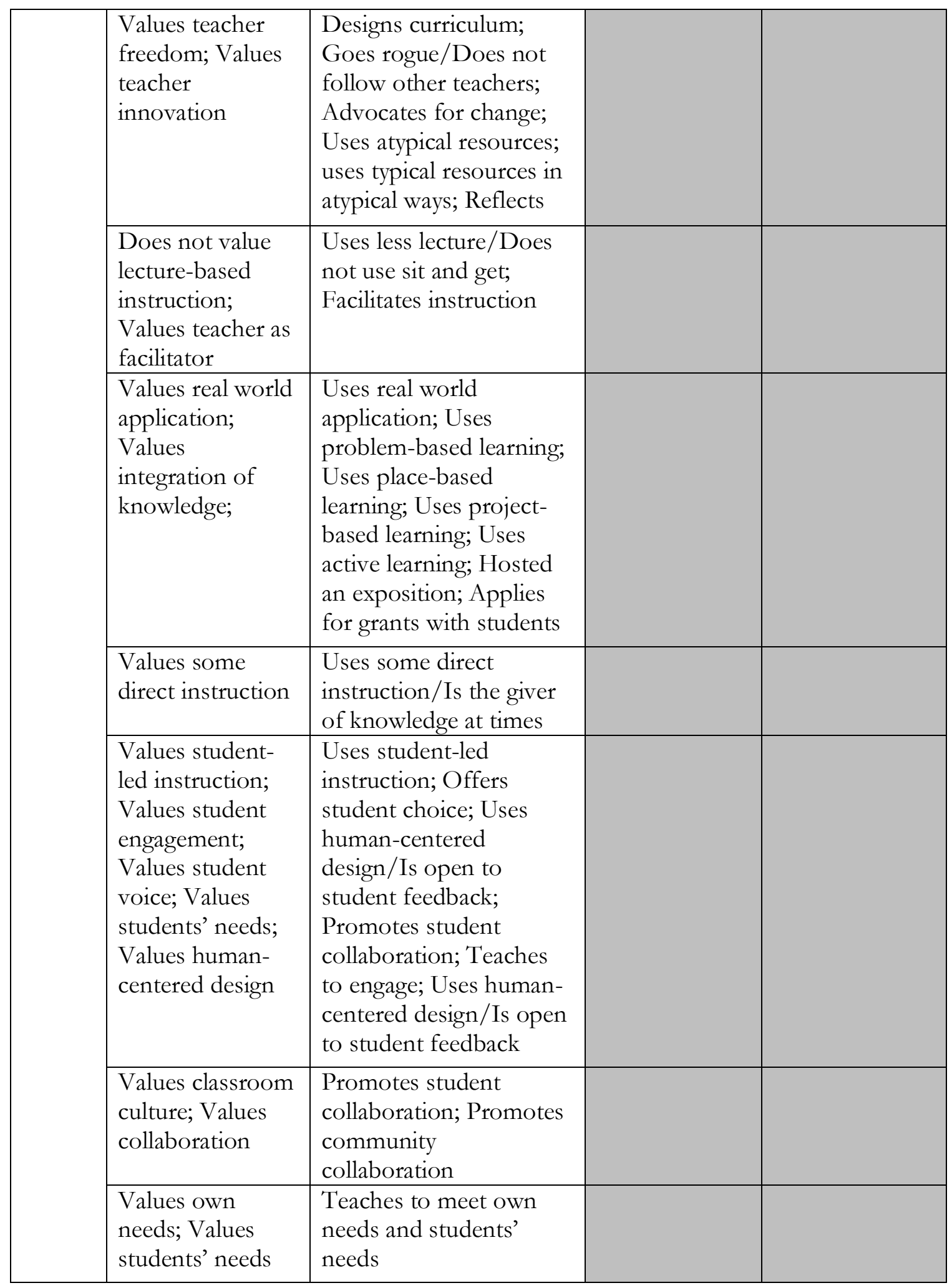

During my interview with Gwen, the facilitator of the collaborative, she shared about

the person she has seen Kellen become. She noted: 
And even Kellen Schneider...she's had this Environmental Science class, and now they put her back in the Biology PLC, and she's right back where she started with being with these people who've done things a certain way forever, and she's already, even after everything she's done, she's still having to fight battles with people who want to PowerPoint kids to death. You know? Because it's Biology and it's more serious, so, when she's over here doing Environmental Science and nobody understands or values it, 'Okay, we're gonna let her do whatever she wants.' But when she's doing Biology, the stakes are higher and we need to control this situation instead of letting her thrive. Now, she's actually become more empowered and so, although she's frustrated, she's just like, 'I'm just gonna smile and nod, and then I'm gonna go do what I'm gonna do.' You know? Which is what a lot of us end up doing, right? [laughs] We're just gonna, we're gonna tell everybody, 'Yeah, sure, I'll do that.' And then you go and you do what you know is best for kids.

Kellen has become a teacher who is unwilling to be governed by opposing opinions, if they contradict her own values, beliefs, and convictions, so in the case that she is met with opposition, she has resolved to "smile and nod and do what she's going to do."

\subsubsection{Kellen's exercise of agency}

Table 8 makes it apparent that, while Kellen experienced some agency before the collaborative, the vast majority of her teaching experience pre-collaborative was lacking in agency, and the vast majority of her experience during and after the collaborative evidences the exercise of agency. Whereas before, Kellen held to many of the same conceptions (albeit a little less developed) that she does now, she was unable to enact curriculum in such a way that aligned with those values and ideals. Now, in spite of various challenges, Kellen has been able to design and enact problem-based, place-based, and project-based curriculum that aligns with her values, involves the community, empowers students, and rewards her, all while remaining standards-based. Her agency is structurally transformative, in that she is willing to break the mold of her department's or school's expectations in order to enact curriculum that aligns with her beliefs; it is structurally transformative, also, in that she is 
designing her own curriculum while still utilizing the state standards, but not being dependent on district curriculum or resources.

\subsubsection{Artifactual evidence of Kellen's agency}

Kellen shared her 2018 Conservation Teacher of the Year Application as a data source for this study, and in this application, she describes what this structurally transformative agency looked like during her time in the collaborative, saying, "For me to create a class that broke the mold of traditional school required students to exit the classroom and go outside, explore issues relevant and related to our community, and engage with the local science and professional community as they proposed solutions to environmental problems."

Other artifacts collected from Kellen serve to strengthen the evidence that she is indeed living out her convictions through her instruction. One such artifact, called "Wonder While We Wander," describes an assignment in which students were to take part on one of the first days of their Environmental Science class. The instructions read:

As we wander around the forested area at the back of Applewood High School's campus work with a partner and complete the following task:

Take five pictures of things you find interesting or are curious about, then answer the following questions about those items:

1. It reminds me of...

2. I notice...

3. I wonder...

This assignment aligns with Kellen's stated intentions to incorporate place-based and inquiry-based learning, and to promote student-led instruction. 
Another assignment given during this class was the Outdoor Classroom project, for which students were to brainstorm solutions to a problem that Kellen had realized: her students who used walkers and wheelchairs were unable to effectively navigate the current outdoor space for learning. Students, working with a partner, were asked to come up with ideas as to how the space could be made useful for any class, noting problems with the space, what is enjoyable about the space, how problems could potentially be solved, resources that would be needed to solve them, and what the plans for the space should be. Students were also asked to answer the question, "If you had to sell the project design to the principal, how would you encourage her to adopt the changes you propose to this space?" According to Kellen, using student ideas, her Environmental Science classes were indeed able to transform the outdoor space at Applewood into a place where all students could learn. This assignment aligns with Kellen's problem-based, student-led, human-centered ideals and her passions for collaboration and real-world application of learning.

Various other documents, shared by Kellen in a comprehensive Google Drive folder, highlight her commitment to project-based and standards-based learning, as well as student engagement and ownership of their learning. On her syllabus for the Environmental Science course that was created during her time in the collaborative, Kellen shared a simple list of what students could expect from the course. It reads:

Things We'll Do, Learn, \& Study

- Identify local flora \& fauna

- Measure habitat \& water quality

- Analyze data

- Identify real-world environmental problems

- Collaborate with students \& professionals 
- Research skills

- Design solutions to environmental issues

- Share ideas with authentic audiences

Likewise, Kellen shared folders full of applications for and descriptions of grants, field trips, and community projects in which she and her students took part or plan to take part.

Among many projects, the following were listed:

2018-2019 Caps for a Cause

2018-2019 Rain Garden for ADA Outdoor Classroom

2019-2020 Cool Pavement Project

2019-2020 Dye Garden

2019-2020 Tree Islands

These projects evidence alignment with Kellen's desire for her curriculum to be locally driven and based on real world problems and solutions.

Among many field trips in which Kellen's students have taken part, the following were included:

2018-2019 UHI Youth Summit

2018 Sustainability Summit

2019 Trout Release

2019 Zoo Challenge Endangered Species

These field trips also align with Kellen's focus on community involvement, student empowerment, and problem-based learning.

Kellen's consistent exercise of structurally transformative agency, especially in recent years, is unmistakable. Her willingness to "go rogue" has allowed her to align her instruction to her ideals, and to do this increasingly as she has become more seasoned. 


\subsection{WALT}

Walt is the final participant in this study who was a member of the collaborative during its first year. Like Tami and Kellen, he served as a mentor in the program during its second year.

Teaching is Walt's second career. Before becoming a high school social studies teacher at Applewood, Walt worked in the private sector for ten years. He has completed his fifth year of teaching and is very grateful for his career move. He teaches primarily World History, but also teaches U.S. History, Political Science, AP Psychology, and AP World History. Walt focused on revamping the World History units for his innovative instructional design during his participation in the collaborative.

Walt attended a nearby private university, where he completed a traditional, fivesemester program and received his Master of Arts in Teaching.

Walt teaches with the goals in mind that his students might become critical thinkers who are continually curious and appreciative of history and its impact on our twenty-first century world. In order to live out this vision, Walt has adopted specific methods, "[trying] to make the students work harder than [him] in all regards." He reportedly makes students write a lot and tries to "incorporate simulations into the lesson plan every week or two." He also shows videos and talks through the videos, having students write reflections on them afterward. He shared that the delivery of his content is "ideally more student-centered than traditional teaching methods."

4.3.1 Walt's curricular conceptions and practices before the collaborative 
Like his fellow Applewood cohort members, Tami and Kellen, Walt repeatedly used the term 'sit and get' to describe the type of instruction in which he took part at the beginning of his career. Similar to Tami and unlike Kellen, Walt not only practiced direct, teacher-led instruction, but he valued it as well (see Table 9 below). His instruction before participating in the collaborative consisted of PowerPoint lecture, note-taking, and book work, and was content-based and test-driven, not skills-based or project-based. Walt described himself at this point in his career as "a central authority and arbiter of knowledge," noting, "I thought I was doing really great when I was giving PowerPoints every day, and like ten percent of the kids loved it, right?"

Table 9. Walt's Conceptions and Practices Before and During/After the Collaborative

\begin{tabular}{|c|c|c|c|}
\hline $\begin{array}{l}\text { Conceptions } \\
\text { Before } \\
\text { Collaborative }\end{array}$ & $\begin{array}{c}\text { Practices Before } \\
\text { Collaborative }\end{array}$ & $\begin{array}{l}\text { Conceptions } \\
\text { During/After } \\
\text { Collaborative }\end{array}$ & $\begin{array}{c}\text { Practices During/After } \\
\text { Collaborative }\end{array}$ \\
\hline $\begin{array}{l}\text {-Valued } \\
\text { teacher-led } \\
\text { instruction } \\
\text {-Valued } \\
\text { teacher as } \\
\text { giver of } \\
\text { knowledge }\end{array}$ & $\begin{array}{l}\text {-Used sit and get } \\
\text { instruction/Lectured } \\
\text { (4) } \\
\text {-Was the } \\
\text { giver/arbiter of } \\
\text { knowledge (4) } \\
\text {-Used test-driven } \\
\text { curriculum } \\
\text {-Did a lot of book } \\
\text { work } \\
\text {-Did not use skills- } \\
\text { based curriculum } \\
\text {-Did not use } \\
\text { project-based } \\
\text { learning }\end{array}$ & $\begin{array}{l}\text {-Values critical } \\
\text { thinking (6) } \\
\text {-Values teacher as } \\
\text { facilitator (4) } \\
\text {-Values active } \\
\text { learning (4) } \\
\text {-Values student- } \\
\text { led instruction (3) } \\
\text {-Values inquiry- } \\
\text { based learning (2) } \\
\text {-Values } \\
\text { innovation (2) } \\
\text {-Values } \\
\text { collaboration }\end{array}$ & $\begin{array}{l}\text {-Promotes critical thinking } \\
(11) \\
\text {-Facilitates learning (8) } \\
\text {-Uses student-led instruction } \\
(6) \\
\text {-Designs curriculum (6) } \\
\text {-Teaches to engage (5) } \\
\text {-Uses project-based learning } \\
\text { (5) } \\
\text {-Practices are not the same as } \\
\text { before collaborative (5) } \\
\text {-Does not lecture; Does not } \\
\text { use sit and get instruction (4) }\end{array}$ \\
\hline
\end{tabular}




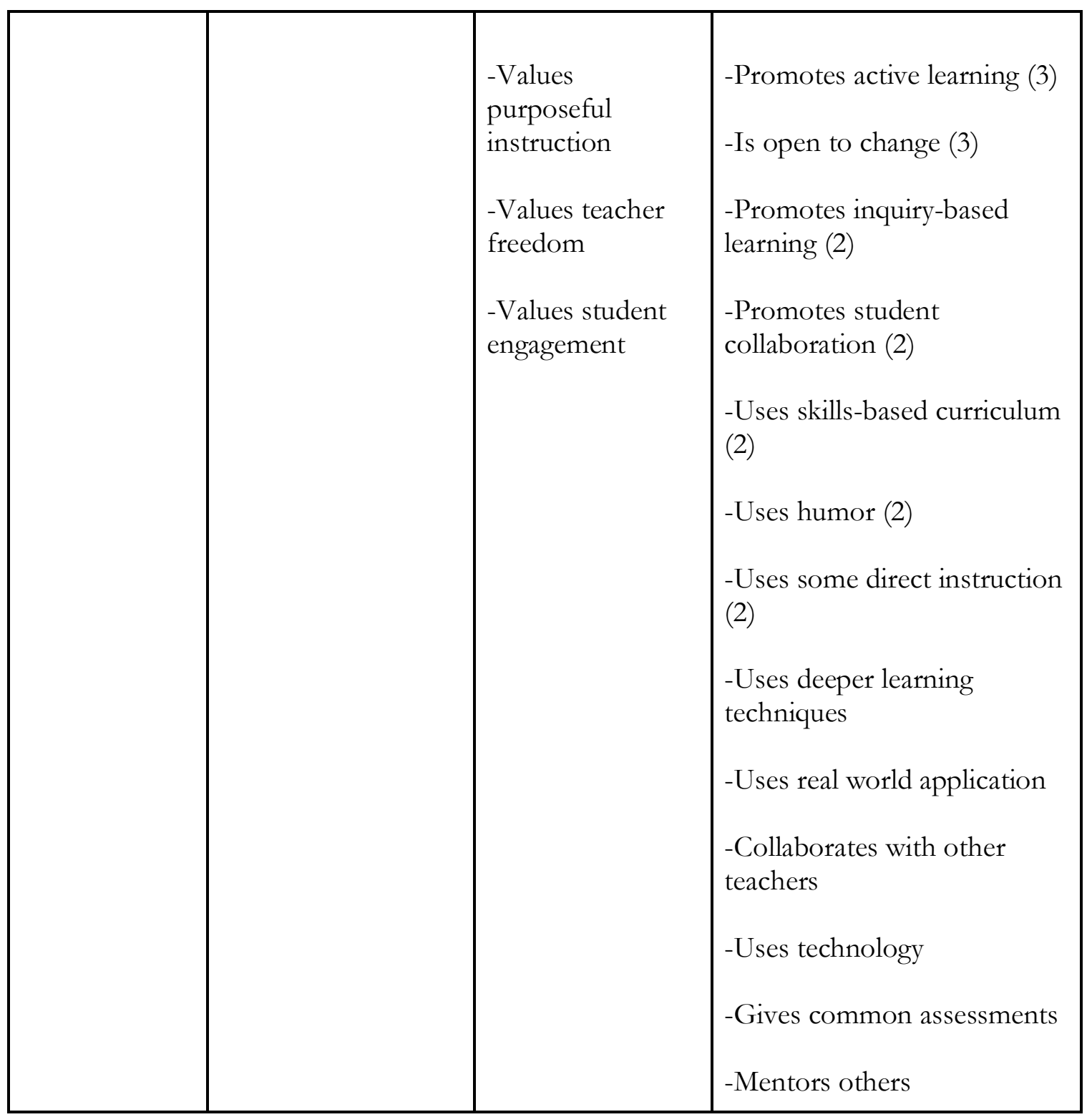

Walt estimated that before the collaborative, seventy-five percent of his class was teacher-centric and driven by PowerPoints and handouts. "So... there were butts in seats and they were doing these things that I was asking them to do," Walt shared in the in terview, "but I was pretty much leading the classroom and giving them answers if they didn't get to them."

4.3.2 Walt's curricular conceptions and practices during and after the collaborative 
Walt experienced a very marked change in both curricular conceptions and practices from the time before his participation in the collaborative to the time during and after his time in it. Whereas before the collaborative, Walt allegedly valued teacher-led instruction and viewed himself as the giver and arbiter of knowledge, during the collaborative he came to value student-led instruction, active learning, and student engagement, and to view himself as a facilitator of classroom learning. Whereas Walt's practice consisted of lecture, book work, and note-taking before the collaborative, his practice transformed during the collaborative to become more skills-based, and to include more student-led instruction, project-based learning, inquiry-based learning, active learning, deeper learning, student collaboration, and real world application.

Over and over again, Walt stated his desire for students to become critical thinkers and agents in their own learning. "My ultimate goal for students is for them to become critical thinkers without need of... a teacher as an intermediary," he said, continuing:

$[\mathrm{N}]$ ot that they would neglect experts in any certain field, but that the teacher wouldn't have to be there to hand out answers or something like that. I don't want to be an answer-giver. But I want them to be able to form interesting, coherent, deep questions and look at different pieces of evidence and strains of evidence of what's gone on in the past, 'cause I teach history. And to come up with their own answers.

Walt noted the value of questions several times throughout the interview and video diaries, contrasting his recent instruction with that of the past in his new emphasis on students as the inquirers, discoverers of answers, and inference-makers, rather than the teacher doling out detached historical facts. "So, being inquisitive and posing questions to students, not just giving away answers I think is one thing that's crucial, right?” he said. "Making them think through [things]." 
Walt described the transformation of his thinking this way: "[F]or a long time I thought, the more I do, the more they're going to learn, but that's really not true. It's the more they do, the more they're gonna learn."

As Walt's thinking began to change, his instruction followed. Reflecting on his time in the collaborative, Walt shared that he shifted to instruction that did not include perpetual direct instruction and PowerPoints. He described his current classroom as "not very teacher-centric for the most part," contrasting the once seventy-five percent direct instruction taking place in his class with twenty-five percent direct instruction taking place in the most recent school year.

Walt described what some of the other practical changes looked like as his class became more student-centric. The World History units remained the same in theme, but his most recent approach to learning differed completely from its historical counterpart. In the world religions unit, for example, Walt shared that in the past, the instruction largely consisted of lecture, note-taking, and book work, culminating in a multiple-choice test. During the collaborative, Walt redesigned this unit to be more student-led and to incorporate more critical thinking. "We had them make a giant puzzle essentially," he said of the final project, "where the pieces represented the religions and, as they intersected and the pieces would touch, they had to come up with similarities for each of the religions, like, so they [the puzzle pieces] couldn't touch unless you had a similarity between them. Like, you know, Judaism and Christianity are both monotheistic, so those pieces could kind of touch there, in that way."

As another example of the shift in his instruction, Walt shared that instead of simply telling students about a Cholera outbreak during the Industrialization Period in Great Britain, he gave students a map and clues, and they had to work together to try to determine 
what event was happening. As Walt shared about this instance in the interview, he was clearly pleased as he remembered the students' intrinsic motivation to complete the assignment, and the kinds of questions that they were asking as they tried to solve the problem, evidencing their critical thinking.

Walt described two other projects that illustrated his teaching transformation. In one, he had students work together to come up with an alternate history of World War II and create a two-minute movie pitch about what that history would have looked like. This project caused students to have to dig more deeply into the information surrounding World War II so that they could "invert some of that knowledge and use some of it to create this alternate historical take."

The final project mentioned by Walt was the creation of a 'Mankind Segment,' or a 'Crash Course' based on a historical event of their choice. They were to work in groups to create an illustrative video, and a script that would help them to narrate the event to teach others about it. The historical event was to be one that had not been covered in the Mankind program that students had watched. If students did not want to create a 'Mankind Segment' or 'Crash Course,' they were free to instead create a Document-Based Question (DBQ) project about an event from modern history, compiling primary and secondary documents on the event in a PowerPoint.

Describing his teaching during and after his time in the collaborative, Walt summarized, "[T] here was [sic.] a lot more inquiry-based things? A lot less PowerPoints? A lot less book work? So I'd say there was [sic.] a lot of differences, and there was much more, I don't know if I want to use the term 'burden,' but there was a heavier cognitive load being carried by the students as opposed to me." 
Walt shared that there has been a lasting change in the way that he designs lessons, taking him out of the central role to serve as more of a facilitator. "There were small incremental changes, I guess, along the way," he noted, "but over time, it's created a big shift in how the curriculum was delivered."

Table 10. Walt's Aligned and Misaligned Conceptions and Practices Before and During/After the Collaborative

\begin{tabular}{|c|c|c|c|c|}
\hline \multirow[t]{2}{*}{$\begin{array}{l}\text { Time } \\
\text { Period }\end{array}$} & \multicolumn{2}{|c|}{ Aligned Conceptions and Practices } & \multicolumn{2}{|c|}{$\begin{array}{c}\text { Misaligned Conceptions and } \\
\text { Practices }\end{array}$} \\
\hline & Conceptions & Practices & Conceptions & Practices \\
\hline 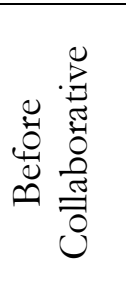 & $\begin{array}{l}\text { Valued teacher- } \\
\text { led instruction; } \\
\text { Valued teacher } \\
\text { as giver of } \\
\text { knowledge }\end{array}$ & $\begin{array}{l}\text { Used sit and get } \\
\text { instruction/Lectured; } \\
\text { Was the giver/arbiter of } \\
\text { knowledge; Did not use } \\
\text { project-based learning; } \\
\text { Did a lot of book work }\end{array}$ & & \\
\hline \multirow{7}{*}{ 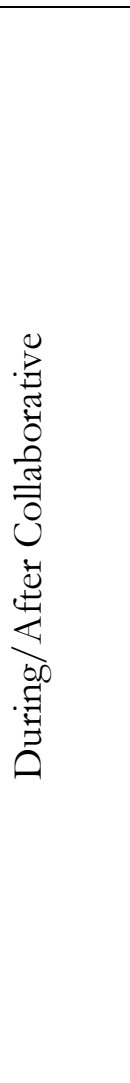 } & $\begin{array}{l}\text { Values critical } \\
\text { thinking }\end{array}$ & Critical thinking & $\begin{array}{l}\text { Values student } \\
\text { engagement }\end{array}$ & $\begin{array}{l}\text { Gives common } \\
\text { assessments }\end{array}$ \\
\hline & $\begin{array}{l}\text { Values student- } \\
\text { led instruction }\end{array}$ & $\begin{array}{l}\text { Student-led instruction; } \\
\text { Project-based learning }\end{array}$ & $\begin{array}{l}\text { Values student- } \\
\text { led instruction }\end{array}$ & $\begin{array}{l}\text { Uses some } \\
\text { direct } \\
\text { instruction }\end{array}$ \\
\hline & $\begin{array}{l}\text { Values teacher } \\
\text { as facilitator }\end{array}$ & $\begin{array}{l}\text { Facilitates learning; } \\
\text { Does not lecture; Does } \\
\text { not use sit and get }\end{array}$ & & \\
\hline & $\begin{array}{l}\text { Values inquiry- } \\
\text { based learning }\end{array}$ & Inquiry-based learning & & \\
\hline & $\begin{array}{l}\text { Values active } \\
\text { learning }\end{array}$ & $\begin{array}{l}\text { Promotes active } \\
\text { learning; Uses } \\
\text { technology; Uses } \\
\text { project-based learning }\end{array}$ & & \\
\hline & $\begin{array}{l}\text { Values } \\
\text { collaboration }\end{array}$ & $\begin{array}{l}\text { Promotes student } \\
\text { collaboration; } \\
\text { Collaborates with other } \\
\text { teachers }\end{array}$ & & \\
\hline & $\begin{array}{l}\text { Values } \\
\text { innovation; } \\
\text { Values teacher } \\
\text { freedom }\end{array}$ & $\begin{array}{l}\text { Designs curriculum; } \\
\text { Mentors others }\end{array}$ & & \\
\hline
\end{tabular}




\begin{tabular}{|l|l|l|l|l|}
\hline $\begin{array}{l}\text { Values } \\
\text { purposeful } \\
\text { instruction }\end{array}$ & $\begin{array}{l}\text { Uses real world } \\
\text { application; Uses } \\
\text { deeper learning } \\
\text { techniques; Uses skills- } \\
\text { based curriculum; } \\
\text { Practices are not the } \\
\text { same as before } \\
\text { collaborative; Is open to } \\
\text { change; Uses project- } \\
\text { based learning }\end{array}$ & & & \\
& Teaches to engage & & \\
& Values student & & & \\
& engagement & & & \\
\hline
\end{tabular}

\subsubsection{Walt's exercise of agency}

Walt exercised a form of agency before his participation in the collaborative, but this agency was structurally reproductive in nature. He reproduced the lessons that were given in the book to the best of his ability, and he reproduced the way that he, himself had been taught history, by standing at the front of the room and lecturing his students.

Now, while Walt still gives common assessments and utilizes some direct instruction, in spite of his value for student engagement and student-led instruction, the majority of his teaching life aligns with his teaching ideals, as shown in Table 10 above. Those things which Walt values, such as collaboration, active learning, inquiry-based learning, student-led instruction and critical thinking, he has, of late, continuously moved toward in his practice.

Walt now expresses structurally transformative agency in his teaching, as he has been willing to break with his previous plans and even the expectations of his department in order to enact his beliefs, values and convictions. Walt described this transformative agency as he shared how his Cholera project came to be, saying,

[T] here was a point second trimester [during the collaborative] where I delivered that lesson first period, and then mid-way through, I was like, 'Man, this really sucks.' So, 
I got onto my phone and I googled it. And somebody had come up with like, a map of London, and these clues that kids would have to read and then figure out... where the Cholera was coming from and...how that was impacted by industrialization, things like that. So, then the rest of that day I did it differently. Well, I did it that way, which was more involving for the students.

Walt chose to change his lesson halfway through the class, because he felt it would be best

for his students' engagement and learning. Later, Walt shared that changes like these are a normal part of his teaching. After realizing that certain lessons are "not great," Walt makes a habit of tweaking or getting rid of them altogether. Walt's early structurally reproductive agency starkly contrasts with his more recent expression of structurally transformative agency.

\subsection{ROBERT}

Robert is the first of four teacher participants in this study who were not a part of the original cohort, and were mentees, rather than mentors, during the most recent school year. Robert is a science teacher at Cromwell Middle School. Similar to Walt, teaching is Robert's second career, as he was in the U.S. Army for twelve years before venturing into life as an educator. Robert is also an anomaly in that he earned his Ed.S. and an Ed.D., both in Curriculum and Instruction, online, before ever setting foot in a classroom as a teacher of record.

He first worked as a teacher of English and Christian religion while living in Taiwan, and then taught in a renowned school in Germany for 3.5 years. Finally, he moved back to the United States, where he had no teaching credentials, and discovered that the state where he currently resides offered a special program for military veterans. He could simply take Praxis II tests to become eligible to teach right away. He passed the exams for middle school 
science and social studies and was soon hired by WCPS as a sixth-grade science teacher, where he has completed 1.5 years in the classroom.

Robert wrote in response to the teacher background survey, "What students need most are people, particularly men, who have increasingly not been working around children enough, to make them a priority and show them that people really exist who will not quit on them. That there are tough men in the world who also care about kids, knowledge, and doing whats [sic.] right. My teaching starts there.” Robert sees his mission in the classroom as primarily that of a caring fatherly figure, and then as one who is able to "show students what science doesn't know" and to "spark their curiosity." Robert summed up the mission of his career by saying, "If not me, then who?"

When asked about the particular teaching methods he practices, he shared that he is "a believer in the basics," and that these 'basics' are what he practices. Robert defined 'the basics' as direct-instruction, repetition, and note-taking. When describing what students receive from his instruction, he stated, 'I ensure my lessons have a clear 'product' so that students know exactly what they're going to get (specific knowledge) for what they're giving up (their time and effort)," going on to share that he seeks to explain concepts clearly, and has students take notes and answer questions in order to gain this 'specific knowledge.' He also tries to give students multiple opportunities to engage with and apply the content, and to give them a lot of careful feedback.

When Robert was asked in the teacher background survey to describe the curriculum for the class on which he focused for the collaborative, he did not cite the content for the class or the skills that students learn, but rather focused on the prepackaged district curriculum in general, noting simply, "My school district's science program offers a packaged curriculum that lacks innovation on many levels." 
For his innovative instructional design, Robert implemented a plan during the final two weeks of the school year, in which he facilitated students' project-based learning, encouraging student choice, engagement, and the use of technology.

\subsubsection{Robert's curricular conceptions and practices throughout his career}

Robert claimed that his conceptions of curriculum have largely remained the same throughout his career, save for a few exceptions. Because Robert's conceptions and practices could not easily be categorized as "before the collaborative" and "during/after the collaborative," I chose to categorize Robert's conceptions and practices differently than those of the other participants, utilizing three frames of time instead of two.

As shown in Table 11 below, the vast majority of Robert's curricular conceptions and practices have been consistent throughout his career, as opposed to being characteristic of the time early in his career or during or after the enactment of his instructional design for the collaborative.

There were only four instances in which Robert mentioned curricular beliefs or values in the past tense: 1) He used to believe that curriculum was a sequence of learning; 2) He did not want to innovate; 3) He valued his colleagues' opinions about his classroom management; and 4) He valued technology.

According to Robert, only two of these previously-held conceptions of his have markedly changed: while he used to believe curriculum was a sequence of learning, he has come to understand it as being more cyclical; and before the collaborative, Robert did not want to innovate, but he has become more open to innovation. Robert still values his colleagues' opinions regarding his classroom management, and he still values technology. 
Among the other conceptions that Robert has consistently held are values for skillsbased learning, direct instruction, prepackaged curriculum, repetition, student note-taking, and differentiation. It is noteworthy that Robert has consistently valued the Common Core, and 'the basics' (described above), and has generally distrusted progressive educational movements and corresponding values for project-based learning, student choice, and flexible seating. He showed obvious disdain for the educational community's emphasis on Scandinavian teaching methods, calling them 'newfangled strategies.' Citing John Hattie's work, with whom Robert reportedly agrees, he shared, "nowhere in there does it say that project-based learning, letting kids choose what they learn, and any of that stuff, is really the most effective."

Robert has also held a belief throughout his career that student engagement can be both helpful and harmful to classroom learning, stating, "[T] he better your lessons are, the more engaging it is, the better the outcome can be. But it can also be the catalyst in many things that take a nosedive."

Robert acknowledged that his beliefs are unpopular amongst the educational community, saying:

I know that, today, everyone's always told that, you know, 'You need to be more creative than that'...but the truth is that if you don't do at least a fair amount of basic instruction and explaining things in the most direct way, and giving kids multiple opportunities to apply what you've taught them and that type of thing...I mean, repetition is still important, it's not gone away. And writing it down, and looking at it again, I mean, these are things that, they aren't the most enjoyable, but, you know, that's why we call it 'schoolwork' and not, you know, 'school play time.'

In seeming contradiction to Robert's claims that his conceptions of curriculum have not changed throughout his career, Robert did mention in one of the video diaries that his conceptions were challenged by his time in the collaborative, but he chose not to elaborate on this statement. 
Table 11. Robert's Conceptions and Practices Early in His Career, Throughout His Career, and During the Enactment of His Instructional Design

\begin{tabular}{|c|c|c|c|c|c|}
\hline $\begin{array}{c}\text { Conceptions } \\
\text { Early in } \\
\text { Teaching } \\
\text { Career }\end{array}$ & $\begin{array}{l}\text { Practices } \\
\text { Early in } \\
\text { Teaching } \\
\text { Career }\end{array}$ & $\begin{array}{c}\text { Conceptions } \\
\text { Consistent } \\
\text { Throughout } \\
\text { Teaching } \\
\text { Career }\end{array}$ & $\begin{array}{l}\text { Practices } \\
\text { Consistent } \\
\text { Throughout } \\
\text { Teaching } \\
\text { Career }\end{array}$ & $\begin{array}{l}\text { Conceptions } \\
\text { During/After } \\
\text { Collaborative }\end{array}$ & $\begin{array}{c}\text { Practices } \\
\text { During } \\
\text { Enactment of } \\
\text { Instructional } \\
\text { Design }\end{array}$ \\
\hline $\begin{array}{l}\text {-Believed } \\
\text { that } \\
\text { curriculum } \\
\text { was a } \\
\text { sequence of } \\
\text { learning } \\
\text {-Did not } \\
\text { want to } \\
\text { innovate } \\
\text {-Valued } \\
\text { technology } \\
\text {-Valued } \\
\text { colleagues' } \\
\text { opinions } \\
\text { about his } \\
\text { classroom } \\
\text { management }\end{array}$ & $\begin{array}{l}\text {-Taught } \\
\text { from } \\
\text { prepackaged } \\
\text { curriculum } \\
\text {-Did not } \\
\text { innovate } \\
\text {-Gave away } \\
\text { Smartboard } \\
\text {-Was not } \\
\text { involving } \\
\text { much } \\
\text { student } \\
\text { choice or } \\
\text { technology } \\
\text {-Did not use } \\
\text { certain } \\
\text { methods } \\
\text { because he } \\
\text { felt he might } \\
\text { lose control } \\
\text { of his } \\
\text { classroom } \\
\text {-Dealt with a } \\
\text { lot of } \\
\text { classroom } \\
\text { management }\end{array}$ & $\begin{array}{l}\text {-Values giving } \\
\text { students a } \\
\text { predetermined } \\
\text { set of } \\
\text { experiences (6) } \\
\text {-Values } \\
\text { differentiation } \\
\text { (5) } \\
\text {-Believes in } \\
\text { teacher as giver } \\
\text { of knowledge } \\
\text { and skills (4) } \\
\text {-Values direct } \\
\text { instruction (3) } \\
\text {-Values } \\
\text { prepackaged } \\
\text { curriculum (2) } \\
\text {-Values student } \\
\text { note-taking (2) } \\
\text {-Does not } \\
\text { value } \\
\text { progressive } \\
\text { methods (2) } \\
\text {-Conceptions } \\
\text { about } \\
\text { curriculum } \\
\text { stayed the } \\
\text { same before } \\
\text { and } \\
\text { during/after }\end{array}$ & $\begin{array}{l}\text {-Deals with a } \\
\text { lot of } \\
\text { classroom } \\
\text { management; } \\
\text { Hesitates to } \\
\text { design } \\
\text { curriculum for } \\
\text { fear of } \\
\text { behavior; } \\
\text { Manages } \\
\text { behavior } \\
\text { more than } \\
\text { he'd like to (3) } \\
\text {-Curriculum } \\
\text { practices } \\
\text { stayed the } \\
\text { same before } \\
\text { and } \\
\text { during/after } \\
\text { the } \\
\text { collaborative } \\
(2) \\
\text {-Is the giver } \\
\text { of knowledge } \\
\text { (2) } \\
\text {-Uses direct } \\
\text { instruction (2) } \\
\text {-Uses } \\
\text { prepackaged } \\
\text { curriculum (2) }\end{array}$ & $\begin{array}{l}\text {-Curricular } \\
\text { conceptions } \\
\text { were } \\
\text { challenged by } \\
\text { time in the } \\
\text { collaborative }\end{array}$ & $\begin{array}{l}\text {-Allowed } \\
\text { students to use } \\
\text { Chromebooks/ } \\
\text { more } \\
\text { technology (4) } \\
\text {-Taught to } \\
\text { engage (3) } \\
\text {-Increased } \\
\text { student choice } \\
\text { (2) } \\
\text {-Sought to } \\
\text { facilitate } \\
\text { instruction (2) } \\
\text {-Used student- } \\
\text { led instruction } \\
\text {-Differentiated } \\
\text {-Asked } \\
\text { students } \\
\text { "What's wrong } \\
\text { with you?" } \\
\text { when they } \\
\text { dropped a } \\
\text { Chromebook } \\
\text {-Allowed more } \\
\text { flexibility } \\
\text {-Used project- } \\
\text { based learning } \\
\text {-Collaborated }\end{array}$ \\
\hline
\end{tabular}




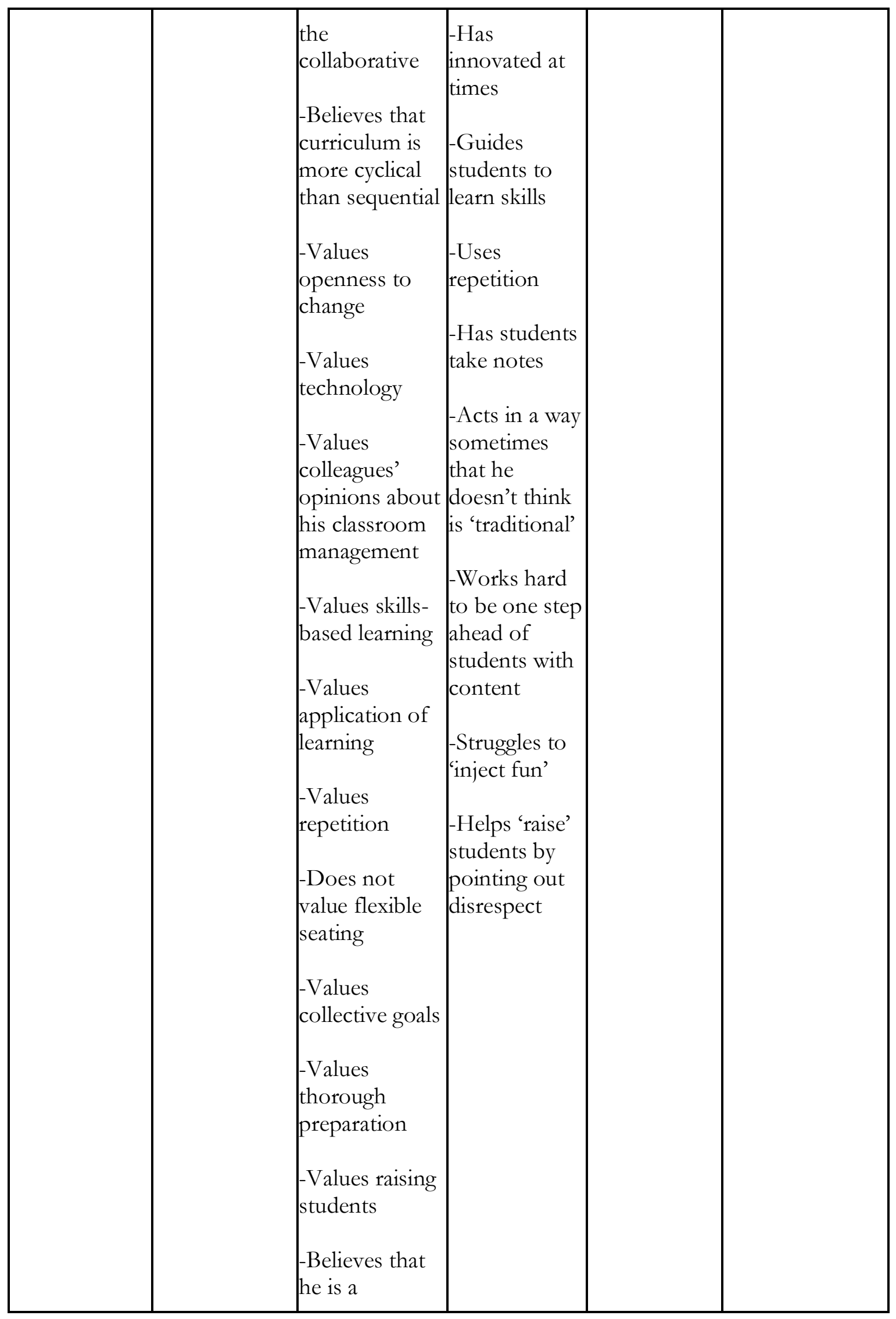




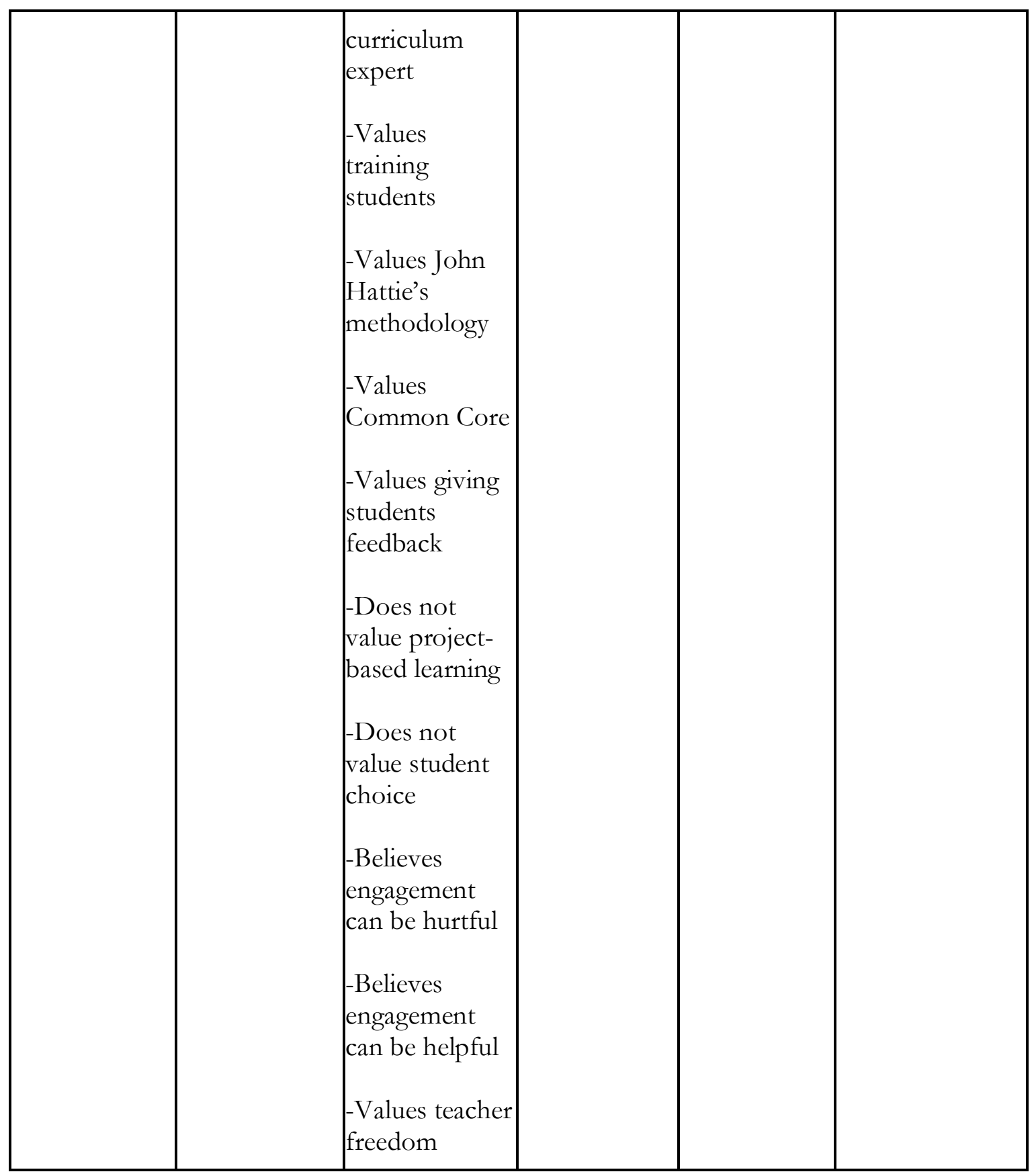

As with his conceptions, the majority of the practices that Robert spoke of were not new or old, but rather continuing practices from the beginning of his career. "It's stayed the same," he responded, when I asked him during the interview whether his curriculum had changed during his time in the collaborative. He spoke of several practices in the past tense, but upon further analysis, it became apparent that these practices were not merely things of the past, but they had continued into the most recent school year. Robert's practice has 
generally included direct instruction of prepackaged curriculum, repetition, note-taking, some skills-based learning, a focus on 'raising' students by teaching them to be respectful, and a struggle to "inject fun." Robert plays the role of "giver of knowledge" more often than not in his classroom. Robert noted that in his practice, he also handles a lot of misbehavior.

\subsubsection{Robert's curricular conceptions and practices during the enactment of his} instructional design

Robert's time in the collaborative began in November and ended in May, but he chose to enact his innovative instructional design during the last two weeks of school only. When he spoke of these two weeks, the types of practices that he associated with them were decidedly different from the practices that he identified with the rest of his career. In the right column of Table 11, I show the characteristics of Robert's practice that were only present during the enactment of his instructional design during the last two weeks of school. During this time, Robert sought to facilitate, rather than to lecture; he allowed for more student-led instruction, rather than his normal teacher-led instruction; he used project-based learning; he taught to engage; he gave students more choice; he differentiated instruction; he allowed for more flexibility in students' learning; he incorporated the use of more technology; and he collaborated with others. These characteristics are not representative of Robert's general practice in the classroom, and Robert made it clear more than once that they were more of an experiment than a resolved transformation. In other words, Robert's role in his classroom only changed — and temporarily so-during the final two weeks of school while he was enacting his instructional design. 
In fact, Robert described the experience of enacting his instructional design, which was full of progressive strategies, as one of opening himself up to exposure, which "led to a lot of problems," such as students breaking a Chromebook. From the beginning, Robert was "hesitant to design something like this for students that I knew had a lot of apathy, that probably would, or I could foresee, not using the time properly.” He added, “And I wasn't totally incorrect in that."

\subsubsection{Robert's exercise of agency}

Below, I highlight Robert's conceptions and practices that were aligned before the collaborative, as well as during and after his participation in the collaborative. I also show the conceptions and practices of Robert's that were misaligned before the collaborative and during and after his participation in the collaborative.

Robert has experienced much alignment and misalignment between his curricular conceptions and practices consistently throughout his career, during his early days as a teacher, and during the enactment of the instructional design that he created during his time in the collaborative.

Table 12. Robert's Aligned and Misaligned Conceptions and Practices Before the Collaborative, Throughout His Teaching Career, and During the Enactment of His Instructional Design

\begin{tabular}{|c|c|c|c|c|}
\hline \multirow[t]{2}{*}{$\begin{array}{l}\text { Time } \\
\text { Period }\end{array}$} & \multicolumn{2}{|c|}{ Aligned Conceptions and Practices } & \multicolumn{2}{|c|}{$\begin{array}{c}\text { Misaligned Conceptions and } \\
\text { Practices }\end{array}$} \\
\hline & Conceptions & Practices & Conceptions & Practices \\
\hline
\end{tabular}




\begin{tabular}{|c|c|c|c|c|}
\hline \multirow{3}{*}{ 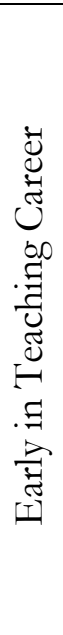 } & $\begin{array}{l}\text { Believed that } \\
\text { curriculum was a } \\
\text { sequence of learning }\end{array}$ & $\begin{array}{l}\text { Taught from } \\
\text { prepackaged } \\
\text { curriculum }\end{array}$ & Valued technology & $\begin{array}{l}\text { Gave away } \\
\text { Smartboard; } \\
\text { Did not } \\
\text { involve } \\
\text { much } \\
\text { technology }\end{array}$ \\
\hline & $\begin{array}{l}\text { Did not want to } \\
\text { innovate }\end{array}$ & Did not innovate & & \\
\hline & $\begin{array}{l}\text { Valued colleagues' } \\
\text { opinions about his } \\
\text { classroom } \\
\text { management }\end{array}$ & $\begin{array}{l}\text { Did not use certain } \\
\text { methods because he } \\
\text { felt he might lose } \\
\text { control of his } \\
\text { classroom }\end{array}$ & & \\
\hline \multirow{9}{*}{ 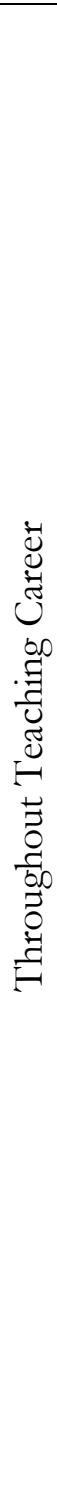 } & $\begin{array}{l}\text { Values training } \\
\text { students; Believes in } \\
\text { teacher as giver of } \\
\text { knowledge and skills }\end{array}$ & $\begin{array}{l}\text { Is the giver of } \\
\text { knowledge }\end{array}$ & $\begin{array}{l}\text { Does not value } \\
\text { progressive methods }\end{array}$ & $\begin{array}{l}\text { Acts in a } \\
\text { way } \\
\text { sometimes } \\
\text { that he } \\
\text { doesn't } \\
\text { think is } \\
\text { 'traditional' }\end{array}$ \\
\hline & $\begin{array}{l}\text { Values prepackaged } \\
\text { curriculum; Values } \\
\text { giving students a } \\
\text { predetermined set } \\
\text { of experiences }\end{array}$ & $\begin{array}{l}\text { Uses prepackaged } \\
\text { curriculum }\end{array}$ & $\begin{array}{l}\text { Believes engagement } \\
\text { can be helpful }\end{array}$ & $\begin{array}{l}\text { Struggles to } \\
\text { 'inject fun' }\end{array}$ \\
\hline & $\begin{array}{l}\text { Values direct } \\
\text { instruction }\end{array}$ & $\begin{array}{l}\text { Uses direct } \\
\text { instruction }\end{array}$ & & \\
\hline & Values repetition & Uses repetition & & \\
\hline & $\begin{array}{l}\text { Values student } \\
\text { note-taking }\end{array}$ & $\begin{array}{l}\text { Has students take } \\
\text { notes }\end{array}$ & & \\
\hline & $\begin{array}{l}\text { Values skills-based } \\
\text { learning }\end{array}$ & $\begin{array}{l}\text { Guides students to } \\
\text { learn skills }\end{array}$ & & \\
\hline & $\begin{array}{l}\text { Values thorough } \\
\text { preparation }\end{array}$ & $\begin{array}{l}\text { Works hard to be } \\
\text { one step ahead of } \\
\text { students with } \\
\text { content }\end{array}$ & & \\
\hline & $\begin{array}{l}\text { Values openness to } \\
\text { change }\end{array}$ & $\begin{array}{l}\text { Has innovated at } \\
\text { times }\end{array}$ & & \\
\hline & $\begin{array}{l}\text { Conceptions about } \\
\text { curriculum stayed } \\
\text { the same before and } \\
\text { during/after the } \\
\text { collaborative }\end{array}$ & $\begin{array}{l}\text { Curriculum practices } \\
\text { stayed the same } \\
\text { before and } \\
\text { during/after the } \\
\text { collaborative }\end{array}$ & & \\
\hline
\end{tabular}




\begin{tabular}{|c|c|c|c|c|}
\hline \multirow{5}{*}{ 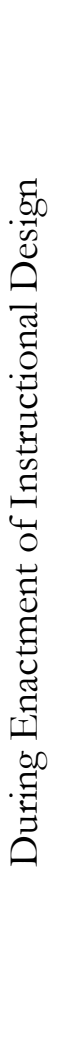 } & $\begin{array}{l}\text { Values } \\
\text { differentiation }\end{array}$ & Differentiated & $\begin{array}{l}\text { Does not value } \\
\text { student choice }\end{array}$ & $\begin{array}{l}\text { Increased } \\
\text { student } \\
\text { choice } \\
\end{array}$ \\
\hline & $\begin{array}{l}\text { Values teacher } \\
\text { freedom }\end{array}$ & $\begin{array}{l}\text { Allowed more } \\
\text { flexibility }\end{array}$ & $\begin{array}{l}\text { Believes engagement } \\
\text { can be hurtful }\end{array}$ & $\begin{array}{l}\text { Made } \\
\text { curriculum } \\
\text { more } \\
\text { engaging }\end{array}$ \\
\hline & Values technology & $\begin{array}{l}\text { Allowed students to } \\
\text { use } \\
\text { Chromebooks/more } \\
\text { technology }\end{array}$ & $\begin{array}{l}\text { Does not value } \\
\text { project-based } \\
\text { learning }\end{array}$ & $\begin{array}{l}\text { Used } \\
\text { project- } \\
\text { based } \\
\text { learning }\end{array}$ \\
\hline & $\begin{array}{l}\text { Believes } \\
\text { engagement can be } \\
\text { helpful }\end{array}$ & Taught to engage & $\begin{array}{l}\text { Values training } \\
\text { students; Teacher as } \\
\text { giver of knowledge } \\
\text { and skills }\end{array}$ & $\begin{array}{l}\text { Sought to } \\
\text { facilitate; } \\
\text { Used } \\
\text { student-led } \\
\text { instruction }\end{array}$ \\
\hline & $\begin{array}{l}\text { Values prepackaged } \\
\text { curriculum }\end{array}$ & $\begin{array}{l}\text { Designed } \\
\text { curriculum }\end{array}$ & $\begin{array}{l}\text { Conceptions about } \\
\text { curriculum stayed the } \\
\text { same before and } \\
\text { during/after the } \\
\text { collaborative }\end{array}$ & $\begin{array}{l}\text { Curricular } \\
\text { practices } \\
\text { were } \\
\text { challenged } \\
\text { by the } \\
\text { collaborative }\end{array}$ \\
\hline
\end{tabular}

\subsubsection{Alignment and misalignment of conception and practice early in Robert's career}

Early in his career, Robert's belief that curriculum was a sequence of learning, his lack of desire to innovate, and his value of his colleagues' opinions regarding the management of his classroom aligned well with his practice: he utilized the prepackaged curriculum, he did not innovate, and he did not use certain methods, for fear that his classroom management would break down. This alignment is expressive of structurally reproductive agency; Robert was seeking to transmit prepackaged information to students and to fit into the mold expected of him, rather than to go beyond it. However, Robert's beliefs and practices also misaligned in the area of technology at this time: while he valued technology, he did not use it, and even gave away his Smartboard. 
4.4.3.2 Alignment and misalignment of conception and practice throughout Robert's career

Throughout his career, Robert has, for the most part, been consistent throughout his career in his expression of structurally reproductive agency. His values for being a giver of knowledge, prepackaged curriculum, direct instruction, repetition, and note-taking have given way to instruction that reflects these ideals. The prepackaged, district-given curriculum has been reproduced by Robert throughout his six years as a teacher. There have, however, been glimmers of structurally transformative agency throughout Robert's career, as he expressed a consistent openness to change that has been followed by innovation at various times.

There has also been some misalignment throughout Robert's career between his beliefs and practices. Robert stated strongly that he distrusts progressive methods, but also noted that he sometimes acts in a way that he doesn't think is 'traditional.' Moreover, while Robert stated a value for student engagement, he also shared that he "struggles to inject fun" and to utilize methods that are engaging. Thus, he has, at least in some ways, been unable to effectively enact that which he has valued throughout his career.

4.4.3.3 Alignment and misalignment of conception and practice during the enactment of Robert's instructional design

Interestingly, during the enactment of the instructional design that he created during the collaborative, Robert experienced a fair share of alignment and misalignment between his curricular conceptions and the practices involved in enacting his design. 
Robert experienced growth in alignment in many areas of practice during the short two weeks of the enactment of his instructional design. Whereas throughout his career, he has seldom innovated, although he has consistently valued teacher freedom, these two weeks were characterized completely by innovation and design; while he has valued differentiation throughout his career but struggled to live it out, Robert clearly differentiated instruction; whereas he has failed to consistently utilize technology in the past, he utilized it greatly during these two weeks; and while he has held the consistent belief that engagement can be helpful, during these two weeks, he was able to teach to engage. In these ways, Robert's instruction during the two weeks of enacting his instructional design was demonstrative of greater agency. However, this agency, instead of the structurally reproductive agency that has marked a large part of his career, was structurally transformative in nature. He designed new instruction and took risks in his attempt to meet his ideals of differentiation, greater technology use, and student engagement.

On the other hand, several of Robert's practices during these two weeks were inconsistent with the values he has claimed to hold. While Robert clearly decried the progressive emphasis on student choice during the interview, he purposefully incorporated more student choice in his instructional design; while he repeatedly voiced wariness regarding a focus on student engagement, he sought to make the curriculum more engaging during these two weeks; while he reported that he does not think project-based learning is effective, he practiced project-based learning in his design; and whereas he continually shared his value for training students, and direct, teacher-led instruction, he sought to facilitate student-led instruction during the two weeks of the enactment of his design. Finally, while Robert shared a belief that prepackaged curriculum exists for teachers, including him, to use it, he strayed from the prepackaged curriculum during the final two 
weeks of school. In these ways, Robert clearly enacted his practice in such a way that did not align with his beliefs, values, and convictions; even though his practices here are suggestive of structural transformation, they are not in keeping with his curricular conceptions, and thus, are not expressive of agency as I define it.

\subsubsection{Artifactual evidence of Robert's agency}

Robert's artifacts, a "Sustainability Challenge Score Sheet," and an alternate project on sustainability, demonstrate agreement with his reported practices during the enactment of his instructional design. The score sheet describes their Sustainability Challenge project and gives instructions, due dates, and spaces to enter students' scores. The score sheet is a Google Doc on which students were expected to attach their assignments while utilizing the technology provided by Robert. The students were also asked to free-write about sustainability problems, research sustainability problems and find solutions, utilize Google Drawings to showcase their solution to a problem, and to create a slideshow to present to the class, using Google Slides.

Alternatively, students could do the following assignment: read a book that was sustainability-related, answer questions provided by Robert, research a problem discussed in the book, create a slide show describing the problem and the science influencing the problem, and use Google Drawings or upload a photo to depict a solution to the problem. Students, again, were asked to insert their work on a Google Doc.

Robert's artifacts support his claims that during the enactment of his instructional design, he sought to incorporate more technology and project-based learning, offer more 
student choice, engage students, and facilitate student-led, rather than teacher-led instruction.

The case of Robert is fascinating. He is full of contradictions. In many ways, his teaching before the enactment of his instructional design was representative of structurally reproductive agency; he acted in such a way that was consistent with his beliefs and values, but these beliefs did not lead him to transform the curriculum, but rather, to reproduce and transmit it. Some of his other values (for technology, for engagement of students) were going unmet before the collaborative, and in his instructional design, he acted on these.

On the other hand, in many ways, Robert forsook his values and beliefs during the final two weeks of school, which very evidently caused a lot of tension for him. For example, he remarked that he does not value student choice, he believes teaching for engagement can be hurtful, and he doesn't value project-based learning, and yet, he made all three of these priorities during the collaborative. He also clearly values curriculum that sees the teacher as the giver of knowledge and skills, but he gave up his rights to this title in favor of student-led instruction and being a facilitator during the collaborative.

It is important to note that Robert saw his actions during the collaborative as a sort of 'testing of the waters,' by which to learn whether or not he could jump fully into these unconventional approaches. This is admirable. It seems as though, in some ways, his experience in the collaborative confirmed what he already believed and was practicing, but in others, it challenged his curricular conceptions and practices.

\subsection{SYDNEY}


Sydney was another mentee in the collaborative during the most recent school year. Like Robert, she teaches at Cromwell Middle school, where she has taught eighth grade reading for two years. She received her bachelor's degree in Education at the same nearby private institution that Tami attended, and is now pursuing her master's in Library Media at a larger state institution, so that "if [she] ever needed to get out of the classroom, [she] could."

Sydney's stated goals for her classroom were consistent across the data: she desires for students to feel safe, for them to have voice and choice in the classroom, and to be engaged in learning. In order to meet these goals, she seeks to build relationships with students, to utilize engaging texts, and to offer choice in seating arrangements and the types of projects that students wish to pursue. She also uses a split classroom model (described in depth below) in order to give students more individualized attention while simultaneously empowering them to take the lead in their learning. She stated in response to the teacher background survey that she regularly employs "small group work, teacher led instruction and PBL [project-based learning]," believing that each has its place in the classroom. For her innovative instructional design during her participation in the collaborative, Sydney focused throughout the year on designing instruction so as to offer students more choice, voice, engagement, and opportunity to foster healthy relationships.

Table 13. Sydney's Conceptions and Practices Before and During/After the Collaborative

\begin{tabular}{|c|c|c|c|}
\hline $\begin{array}{c}\text { Conceptions } \\
\text { Before } \\
\text { Collaborative }\end{array}$ & $\begin{array}{c}\text { Practices Before } \\
\text { Collaborative }\end{array}$ & $\begin{array}{l}\text { Conceptions } \\
\text { During/After } \\
\text { Collaborative }\end{array}$ & $\begin{array}{c}\text { Practices During/After } \\
\text { Collaborative }\end{array}$ \\
\hline
\end{tabular}




\begin{tabular}{|c|c|c|c|}
\hline 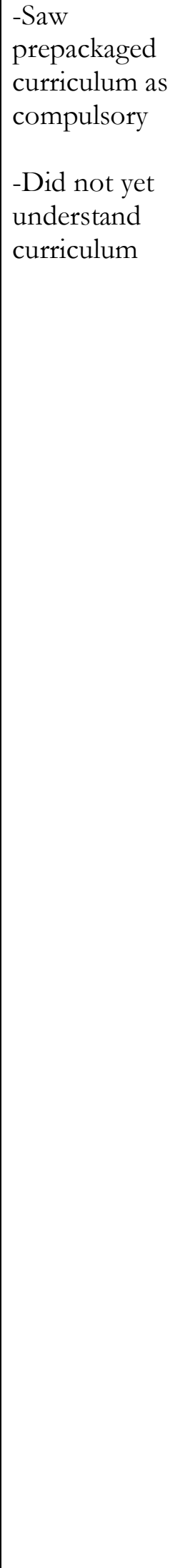 & $\begin{array}{l}\text {-Used all of the } \\
\text { books that were } \\
\text { recommended in } \\
\text { prepackaged } \\
\text { curriculum } \\
\text {-Did whatever } \\
\text { she was told to } \\
\text { do, and what the } \\
\text { other eighth } \\
\text { grade teacher was } \\
\text { doing } \\
\text {-Yelled at } \\
\text { students } \\
\text {-Used CHAMPS } \\
\text { in her classroom } \\
\text {-Promoted } \\
\text { student note- } \\
\text { taking } \\
\text {-Used teacher-led } \\
\text { instruction }\end{array}$ & 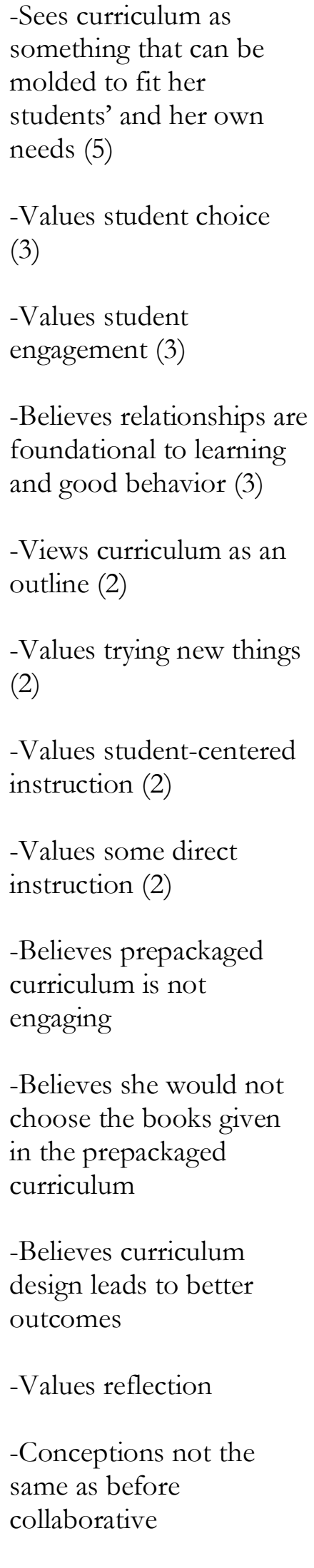 & 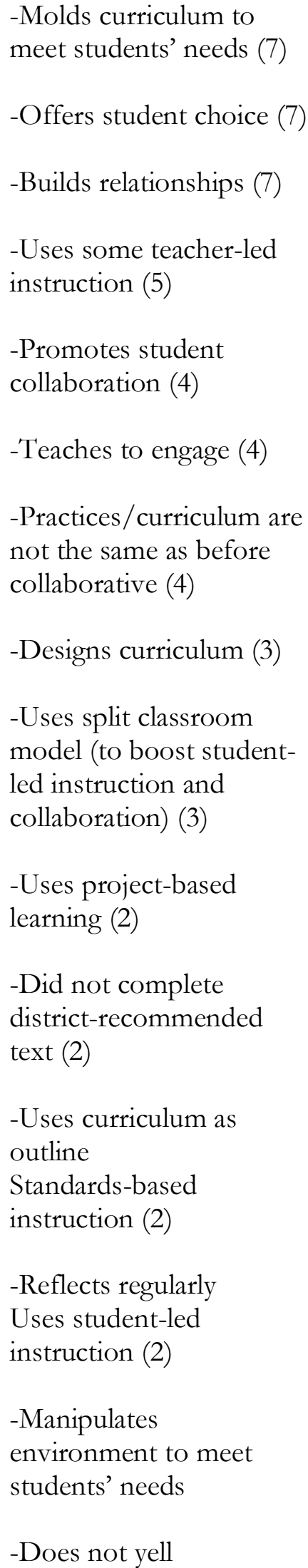 \\
\hline
\end{tabular}




\begin{tabular}{|l|l|l|}
\hline & $\begin{array}{l}\text {-Believes yelling is } \\
\text { ineffective }\end{array}$ & $\begin{array}{l}\text {-Created a classroom } \\
\text { library } \\
\text {-Sets strong expectations } \\
\text {-Uses CHAMPS for } \\
\text { classroom management } \\
\text {-Carried out goals via the } \\
\text { collaborative } \\
\text {-Uses a variety of } \\
\text { instructional methods } \\
\text {-Collaborates with other } \\
\text { teachers }\end{array}$ \\
\hline
\end{tabular}

\subsubsection{Sydney's curricular conceptions and practices before the collaborative}

Sydney's curricular conceptions and practices from before her participation in the collaborative are completely distinct from those that she held and enacted during and after her time in the collaborative, as shown in Table 13 above.

Sydney reported in the interview that before her participation in the collaborative, she viewed prepackaged curriculum as compulsory, feeling that she had no choice in what or how to teach in her classroom. She also claimed that she did not yet understand curriculum at that time. In her practice, Sydney followed the prepackaged curriculum and that which the other eighth grade teacher was doing in her classroom, completing all of the books recommended in the district curriculum, utilizing teacher-led instruction, and having students take notes as their main form of involvement. She also claimed that she used to yell at students in order to manage her classroom, though she also used CHAMPS [a classroom management strategy], which she learned during student teaching. Of all of these practices, 
the only one that has stood the test of time is Sydney's use of CHAMPS, which she allegedly practices "to this day."

\subsubsection{Sydney's curricular conceptions and practices during and after the collaborative}

Sydney reported that during and after the collaborative, her curricular conceptions and practices were strikingly different than before. Regarding her conceptions, while she used to see prepackaged curriculum as compulsory, Sydney now sees it as something that can be molded to meet her students' and her own needs; and whereas she claimed not to have understood curriculum before, she now has developed opinions about it, seeing it as an outline. Speaking of the district curriculum, she stated, "I kind of use it as a map, but I also don't...feel like I have to do exactly what it's telling me, and I realize where I can kind of create these new things... So, I see it more as kind of like a [sic.] outline, but I just kind of manipulate it to fit...my needs and what my students need."

Sydney stated the belief that prepackaged curriculum is not engaging, and that curriculum design leads to better outcomes for students. Her emphases on relationship, engagement, and student choice and voice developed throughout her collaborative year as well.

Sydney's practice during her collaborative year unmistakably followed her new conceptions. During her participation in the collaborative, she did not complete all of the recommended texts in the district curriculum, but rather chose some outside texts to help students to meet the standards; she also traded teacher-led instruction for student collaboration and student-led instruction. She stated, "there was a lot less time this year that

I was in front of the classroom. A lot of the times...it's almost like I was bored, because my 
kids knew what they were doing, there was nothing for me really to stick my head into...they were doing what they needed to do, and I was just there if they needed me."

Instead of doing all that she was 'told' by the district and following after another teacher, Sydney shaped the curriculum to meet students' needs, manipulating content, method, and environment to do so. Sydney did not yell at students any longer, focusing rather on building relationships with them and setting clear expectations in the classroom. "I went in, set strong...expectations, and went from there," she said, continuing:

[T] hey really respected that the expectations were set. They knew exactly what to do in my classroom, how to act. And I didn't stray from those, but I also asked them questions about, like, their life outside of school, and got to know them, and we would have free time where they could...you know, learn about me. And I joke with them a lot, so we have a lot of laughs in my classroom.

Finally, adopting a split-classroom model, Sydney allowed for half of the class to be given more individual attention and direct instruction, while the other half spent their time working independently and in groups on choice activities. The students rotated their roles every other day, so that all students had an equal amount of time receiving individual attention and direct instruction, as well as participating in independent work and group work. Sydney noted, "They had voice, they had choice, they got to talk, they got to...choose where they sat in the classroom."

\subsubsection{Sydney's exercise of agency}


Even though Sydney has only taught for two short years, she has clearly exercised agency as an educator. Her agency before the collaborative, however, looked very different from the agency that she expressed during and after her time in it.

Before her participation in the collaborative, Sydney's curricular practices aligned with her conceptions regarding curriculum (see Table 14 below); she viewed prepackaged curriculum as compulsory, so she led students into the transmission of prepackaged curriculum; she was not yet sure of how to navigate curriculum on her own, so she followed another teacher's practice. Sydney's agency before the collaborative was structurally reproductive, as she was reproducing the structures of the prepackaged curriculum and another teacher's practice, instead of transforming structures.

Table 14. Sydney's Aligned and Misaligned Conceptions and Practices Before and During/After the Collaborative

\begin{tabular}{|c|c|c|c|c|}
\hline \multirow[t]{2}{*}{$\begin{array}{l}\text { Time } \\
\text { Period }\end{array}$} & \multicolumn{2}{|c|}{ Aligned Conceptions and Practices } & \multicolumn{2}{|c|}{$\begin{array}{c}\text { Misaligned Conceptions and } \\
\text { Practices }\end{array}$} \\
\hline & Conceptions & Practices & Conceptions & Practices \\
\hline \multirow{2}{*}{ 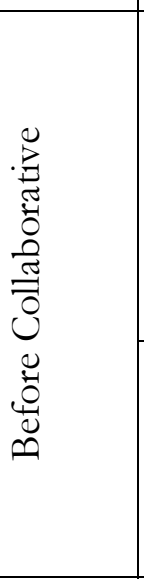 } & $\begin{array}{l}\text { Saw prepackaged } \\
\text { curriculum as compulsory }\end{array}$ & $\begin{array}{l}\text { Used all of the books } \\
\text { that were } \\
\text { recommended in } \\
\text { prepackaged } \\
\text { curriculum; Used } \\
\text { teacher-led } \\
\text { instruction }\end{array}$ & & \\
\hline & $\begin{array}{l}\text { Did not yet understand } \\
\text { curriculum }\end{array}$ & $\begin{array}{l}\text { Did whatever she } \\
\text { was told to do, and } \\
\text { what the other eighth } \\
\text { grade teacher was } \\
\text { doing }\end{array}$ & & \\
\hline 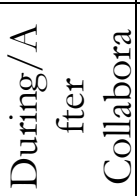 & $\begin{array}{l}\text { Believes prepackaged } \\
\text { curriculum is not engaging; } \\
\text { Believes curriculum design } \\
\text { leads to better outcomes }\end{array}$ & Designs curriculum & & \\
\hline
\end{tabular}




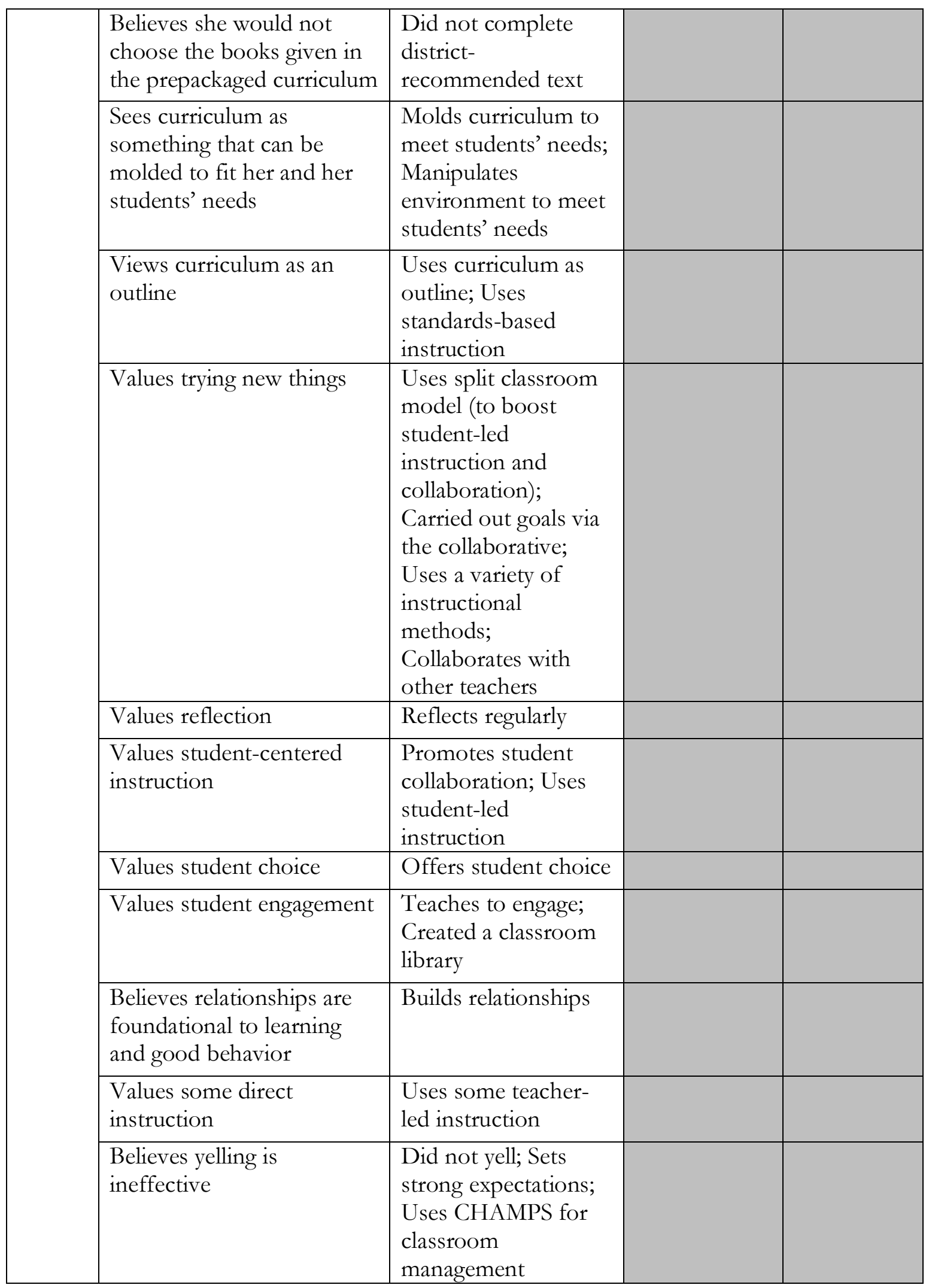




\begin{tabular}{|l|l|l|l|l|}
\hline $\begin{array}{l}\text { Conceptions not the same } \\
\text { as before collaborative }\end{array}$ & $\begin{array}{l}\text { Practices/curriculum } \\
\text { are not the same as } \\
\text { before collaborative }\end{array}$ & & \\
\hline
\end{tabular}

Sydney's agency during and after the collaborative was of a different sort; her new conceptions about curriculum led her to align her practice with them, but this required structural transformation, not reproduction. As Sydney came to believe that prepackaged curriculum is not to be transmitted, that certain readings could be more helpful to students' learning, and that curriculum is merely an outline to be filled in creatively by the teacher, she was led to begin to design her own classroom instruction, which involved throwing out a district-recommended text and instead, choose common lit articles for students to read. She described the shift, saying:

[T] he first text that we were supposed to read of the year, I just completely threw out. We looked at the standards without doing that text, and it really allowed me to get to know my students better, to know their likes, their dislikes, what their needs were, to be the most successful. And it really helped me to create relationships in the classroom as well. I enjoyed teaching, they enjoyed learning, and it was very beneficial.

Sydney was also led to adopt a split-classroom model in order to cater to her newfound values for student-centered instruction, student choice, student engagement, and relationship.

Sydney's case offers a simple picture of a teacher whose early practice was dictated by her early and undeveloped conceptions. Her early and structurally reproductive agency existed not because it was well thought-out, but because she did not know any better. As her curricular conceptions began to transform, her classroom practice followed seamlessly. Sydney was able to clearly articulate the conceptual convictions behind her classroom practice, reflecting a bold, structurally transformative agency, which she admitted she needs to "be brave" in order to maintain. "I don't want to be afraid to try those new things," she 
stated, affirming that to her, trying and failing is better than not trying new things at all. " $[\mathrm{I}] \mathrm{t}$ is okay to fail, if you're trying these new things to make your classroom better for your students."

\subsubsection{Artifactual evidence of Sydney's agency}

Sydney provided three artifacts from her participation in the collaborative, which were projects based on the units surrounding the books Flowers for Algernon and The Diary of Anne Frank.

One assignment was entitled "Blackout Poetry: Flowers for Algernon." Sydney provided students with a rubric for the assignment, on which students would be graded for "Quality of Construction," "Content," "Analysis of Poem/Word Choice," and "Image." Under the rubric, the project was described this way:

Directions: Student will create an image that also depicts a poem on a progress report from Flowers for Algernon by Daniel Keyes. Student will find the most important words on the page and work around these words to create a poem centered around the theme of the progress report. Student will "Black Out" the remaining words on the page by using markers to create an image that depicts the theme of the progress report.

Things to consider: If you know you are not artistic and this project will not produce your best work, consider one of the other projects instead.

Although Sydney's note about not being 'artistic' may be a sign of her greenness as a teacher (as many students in middle school may not even have explored various art forms at this point in their life), this project aligns with Sydney's intentions for the incorporation of 
student choice, voice, and engagement. Students were to work creatively and to express themselves by focusing on the words that stood out to them. The fact that students could choose this project or another evidences student choice. This project also aligns with Sydney's emphasis on standards-based learning, as students were to focus on theme.

Sydney provided one of the other projects that students could choose to complete in response to Flowers for Algernon as an artifact. This document was entitled "One Pager Rubric Flowers for Algernon," and asked students to create a "one pager" assignment that asked students to include the following:

at least one hand drawn picture that centers around the theme of the text, three quotes that depict the significance of the picture, three character traits from before and after surgery, character types of Charlie from before and after surgery, one sentence showing how you connected with the reading, makes connections between the text and current events using sketches and text.

** On back or separate sheet of paper: One paragraph reflection explaining how you met the requirements.

Again, students were encouraged to choose another assignment if they did not believe that this one would not produce their best work. The rubric given to students was the same as the one included with the Blackout Poetry assignment.

This project aligns, once again, with Sydney's emphases on student choice, voice, and engagement, in that they are asked to make personal connections, creatively express the theme through an original drawing, and to choose another project if this one did not suit them.

Finally, Sydney offered an artifact entitled "Graffiti Wall Rubric.” On the assignment, students were asked to do the following: 
Write Graffiti about the play "The Diary of Anne Frank.”

A. Make a poster board look like a brick wall with color or construction paper.

B. Cut your words out of construction paper that represent the themes, characters, relationships, conflicts, and resolutions in the text or significant life events, conflicts/resolutions, significance/Impact and carefully glue them to the wall. (20 words at least)

C. Include a summary or story line about what is on your wall and why in two 5-7 sentence paragraphs. Type this neatly and attach it to the board. This needs to reflect theme, conflict, and other significance of the words. D. Include your name and class period on the front bottom right hand corner of the wall (in the brick).

E. Note: Your poster needs to look like a graffiti wall—neatness does count. Creativity is important as well as content.

In spite of this document's being labeled as a 'rubric,' there was no rubric attached to it. Moreover, the form of the project students were asked to complete—a graffiti wall—does not seem to have a clear connection to the text to which they were responding. Still, this assignment aligns with Sydney's curricular conceptions; her emphasis on standards-based instruction led her to direct students toward theme, characters, relationships, conflicts, and resolutions in the book; her value for student engagement opened the door to the creative medium of the graffiti wall; she also shared that creativity was just as important as content, demonstrating a value for student voice. Sydney's artifacts confirm the alignment that was suggested by her reported conceptions and practices in the teacher background survey, interview, and video diaries. 
When I spoke to Sydney during the interview, her plans for the new school year were already underway. Transforming the first unit of eighth grade reading once again, she will replace the common lit articles with a unit centered around independent reading. It is clear that Sydney's structurally transformative agency will continue to be expressed in new ways as she gains experience and adapts instruction to her context.

\subsection{HANNAH}

Hannah has completed her fifth year of teaching middle school English. For the first three years of her career, she taught sixth grade at a private school in another state, and for the last two years, she has taught eighth grade English at Whitfield Middle School in WCPS. She joined the collaborative during the most recent school year as a mentee, but surprisingly to her, the product that came out of her collaborative year involved her becoming a mentor and school leader to the faculty in her building. Unlike the five participants mentioned before her, and similar to Michelle after her, Hannah's instructional design did not involve classroom curriculum innovation, but school-wide innovation.

Hannah pursued her teacher education through the Bidwell Teacher Residency Program, which she described as a selective one-year program in the northeast that involved pursuing a full-time master's of education and full-time student teaching. Hannah "see[s] literacy and a quality education as a right that all students deserve and need," and believes that the purpose of education is "to give students tools and skills to attain their personal goals and hopes in the world, and also the opportunity to discover and decide what those goals and hopes might be." 
Of all of the teacher participants in this study who were asked to describe the instructional methods they regularly use, Hannah described the broadest range of protocols and activities that she uses in the classroom in order to facilitate students' learning, such as station activities, direct instruction with workshop practice, read aloud think aloud modeling, reciprocal teaching, Socratic Seminar, and project-based learning, among many others.

Hannah noted in response to the teacher background survey, "If we want students to become lifelong learners, it is up to us (educators) to also live and model this same principle." She allowed this passion to drive her instructional design during her participation in the collaborative, in which she focused on helping her principal to revise faculty-wide professional development for the following school year. "Under the new plan teachers will be offered a menu of different "pathway" topics ranging from new teacher support to more advanced ways to differentiate instruction, or apply group work opportunities, or better incorporate technology in the classroom," she wrote in the teacher background survey. Her plan involves every teacher selecting a topic that is aligned with their personal instructional goal for that year and attending staff-led workshops where they can receive more information surrounding their topic and exchange ideas with colleagues. "They would also observe other colleagues working on similar goals in peer support," she wrote. According to Hannah, this plan was to be enacted during the following school year.

\subsubsection{Hannah's curricular conceptions throughout her career}


Hannah stated in a video diary, "I don't think that... my participation in the collaborative...changed a big way of how I see education." Hannah's curricular conceptions have largely remained the same throughout her five years of teaching. In the areas of rigor, habits of planning, and instructional priorities, however, her emphases have slightly shifted. "I think I used to feel a lot of pressure that...my goal was to get all of my students up to and beyond grade level? And whatever that means? And I put more onus on standardized test results than I do now" she said in the interview. Hannah made sure to state that she still believes every student is capable of reaching grade level benchmarks or beyond, but "it's not how [she] measure[s]...a student's success by any means.” Instead, she wants to see a student's grade level proficiency trending forward, and that they make at least a year's worth of progress in her class. Hannah stated that she no longer thinks that making students feel pressure to reach grade level proficiency is best practice. "That's my job to worry about part of it," she noted. She desires for students to feel that they are making progress, but also to see greater relevance and purpose for what they are doing in class.

From the beginning of her career, Hannah has held onto a quote from her teacher training program: "There is no road, and you make the road by walking." She believes that she "[has] no set curriculum other than the standards, technically," but that her curriculum is promoting students' proficiency in reading, writing, speaking, and listening according to the state standards. This conception of Hannah's has remained consistent.

\subsubsection{Hannah's curricular practices throughout her career}


Similar to her curricular conceptions, Hannah's stated that her classroom practice had only shifted in minor ways. The methods that she uses have been consistent, but she shared that she now addresses the standards more cyclically than before: "So, instead of making sure that everyone understands, or, you know, trying to have the goal that everyone is proficient at theme by the time we get to November, knowing that in every unit we do, we will talk about theme." Now, as then, Hannah employs reciprocal teaching strategies, Socratic Seminar, group reading protocols, literary circles, and explicit instructional modeling, among other strategies; but now, Hannah seeks to be more careful not to "go over kids' heads" by involving too much higher order thinking, as she feels she used to struggle to scaffold learning sufficiently for her students.

\subsubsection{Hannah's conceptions and practices regarding teacher leadership and professional} development

Hannah's year in the collaborative did not promote marked changes in her own classroom practice, but it did cause much development in her curricular conceptions and practices regarding teacher leadership. For Hannah, this year reinforced for her "the importance and notion that everything that we do, that we want for our students, in terms of curriculum and in terms of their skill set, and in terms of what good instruction looks like, needs to be mirrored for faculty in whatever professional development we receive." She noted that teachers must be treated as learners and students, too, and offered best practice by the leaders of their professional development opportunities, including differentiation, opportunities for collaboration, and opportunities for choice. Hannah stated that her value 
for effective professional development for teachers ultimately will lead to greater outcomes

for teachers and students:

[M] y philosophy for my own teaching practice is that I see education, or quality education, as a right that all students should have and need... and so, I think students need a consistent, and consistently positive experience throughout their learning. And I also think that teachers are, for the most part, doing the best they can within their own knowledge and abilities. And if we give teachers, and if my school can better give teachers a way to support their practice and grow their own practice, then there will be positive outcomes for teachers and students... alike. And also, just that teachers, we are the number one tone setters and change makers... within the context of our own classroom.

Hannah hopes that her instructional pathways design, created in conjunction with the principal and support staff at her school, will allow for teachers' professional development opportunities "to go from being a very, very one-off and segmented list of opportunities and curriculums, of one-off workshops, to a more continuous set of pathways, where teachers are working towards a specific instructional goal that they have, or they're choosing for themselves."

Hannah sees her practice in her school at large as having changed a lot during her collaborative year. She shared that before, she was focused on bettering her own practice, but now she thinks about what role and contribution she can make to the school as a whole and has been willing to advocate for change in this area. "And just because I'm a young teacher, doesn't mean I don't have coaching and experience to offer," she said.

Table 15. Hannah's Conceptions and Practices Early in Her Career, Later in Her Career, and During/After the Collaborative 


\begin{tabular}{|c|c|c|c|c|c|}
\hline $\begin{array}{l}\text { Conceptions } \\
\text { Early in Her } \\
\text { Career }\end{array}$ & $\begin{array}{l}\text { Practices Early } \\
\text { in Her Career }\end{array}$ & $\begin{array}{l}\text { Conceptions } \\
\text { Later in Career }\end{array}$ & $\begin{array}{l}\text { Practices Later } \\
\text { in Career }\end{array}$ & $\begin{array}{c}\text { Conceptions } \\
\text { During/After the } \\
\text { Collaborative }\end{array}$ & $\begin{array}{c}\text { Practices } \\
\text { During/After the } \\
\text { Collaborative }\end{array}$ \\
\hline $\begin{array}{l}\text {-Valued } \\
\text { students } \\
\text { meeting and } \\
\text { exceeding } \\
\text { grade level } \\
\text {-Valued } \\
\text { standardized } \\
\text { test results }\end{array}$ & $\begin{array}{l}\text {-Used } \\
\text { explicit } \\
\text { instructional } \\
\text { modeling (2) } \\
\text {-Chose } \\
\text { relevant } \\
\text { texts (2) } \\
\text {-Went over } \\
\text { kids' heads } \\
\text {-Used: } \\
\text { Literary } \\
\text { circles; } \\
\text { Group } \\
\text { reading } \\
\text { protocols; } \\
\text { Reciprocal } \\
\text { teaching } \\
\text { strategies; } \\
\text { Socratic } \\
\text { Seminar; } \\
\text { Split } \\
\text { classroom; } \\
\text { Small group } \\
\text { mini lessons } \\
\text { based on } \\
\text { student } \\
\text { progress; } \\
\text { Exit tickets } \\
\text {-Did not } \\
\text { have } \\
\text { confidence } \\
\text { to advocate } \\
\text { for change } \\
\text { in teacher } \\
\text { professional } \\
\text { development } \\
\text {-Was } \\
\text { focused on }\end{array}$ & $\begin{array}{l}\text {-Values } \\
\text { students' } \\
\text { building } \\
\text { language skills } \\
\text { (6) } \\
\text {-Values } \\
\text { standards- } \\
\text { based } \\
\text { curriculum (3) } \\
\text {-Values } \\
\text { students } \\
\text { making at } \\
\text { least a year's } \\
\text { worth of } \\
\text { progress (3) } \\
\text {-Believes that } \\
\text { students' } \\
\text { success } \\
\text { should not be } \\
\text { measured by } \\
\text { their grade } \\
\text { level language } \\
\text { skills (3) } \\
\text {-Values the } \\
\text { "hidden } \\
\text { curriculum" } \\
\text { (2) } \\
\text {-Conceptions } \\
\text { of curriculum } \\
\text { are the same } \\
\text { as before } \\
\text { collaborative } \\
\text { (2) } \\
\text {-Views } \\
\text { curriculum as } \\
\text { something } \\
\text { that is not set, }\end{array}$ & $\begin{array}{l}\text {-Uses } \\
\text { project- } \\
\text { based } \\
\text { learning (4) } \\
\text {-Offers } \\
\text { student } \\
\text { choice (4) } \\
\text {-Starts } \\
\text { explicit and } \\
\text { releases } \\
\text { more } \\
\text { control to } \\
\text { students (3) } \\
\text { - } \\
\text { Collaborates } \\
\text { with other } \\
\text { teachers (3) } \\
\text {-Promotes } \\
\text { inquiry- } \\
\text { based } \\
\text { learning (2) } \\
\text {-Uses: } \\
\text { Novel } \\
\text { studies; } \\
\text { Writing } \\
\text { projects; } \\
\text { Research } \\
\text { projects; } \\
\text { Whole class } \\
\text { novel; } \\
\text { Socratic } \\
\text { Seminar (2); } \\
\text { Stations; } \\
\text { Direct } \\
\text { instruction } \\
\text { with } \\
\text { workshop } \\
\text { practice; }\end{array}$ & \begin{tabular}{|l}
-Values \\
teacher \\
performance \\
$(7)$ \\
-Values \\
teacher \\
training (5) \\
-Values \\
differentiation \\
in teacher \\
leadership (3) \\
-Values \\
alignment of \\
school goals \\
with \\
professional \\
development \\
and teachers' \\
goals
\end{tabular} & $\begin{array}{l}\text {-Plans teacher } \\
\text { training (4) } \\
\text {-Promotes } \\
\text { teacher choice } \\
\text { (4) } \\
\text {-Promotes } \\
\text { differentiation } \\
\text { in teacher } \\
\text { leadership (3) } \\
\text {-Plans } \\
\text { professional } \\
\text { development } \\
\text { curriculum } \\
\text { around school } \\
\text { alignment of } \\
\text { goals and } \\
\text { practices (3) } \\
\text {-Advocates for } \\
\text { an } \\
\text { idea/change } \\
\text { (2) } \\
\text {-Pursues } \\
\text { school-wide } \\
\text { faculty } \\
\text { initiative } \\
\text {-Uses project- } \\
\text { based learning } \\
\text { for teachers } \\
\text {-Promotes } \\
\text { teacher } \\
\text { engagement } \\
\text { game for } \\
\text { teachers }\end{array}$ \\
\hline
\end{tabular}




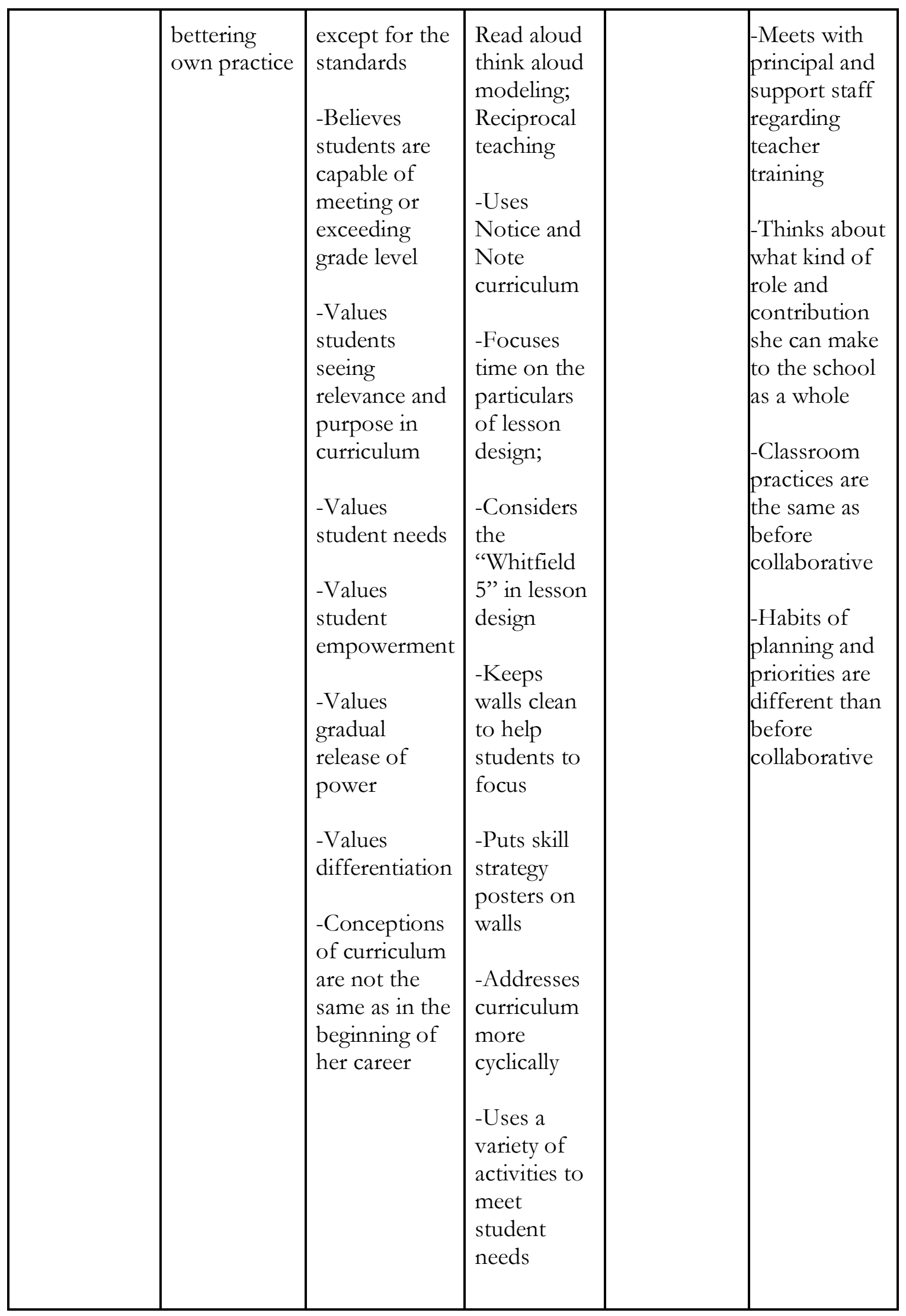




\begin{tabular}{|l|l|l|l|l|}
\hline & $\begin{array}{l}\text {-Chooses } \\
\text { relevant } \\
\text { texts for } \\
\text { students } \\
\text {-Promotes } \\
\text { real world } \\
\text { application } \\
\text {-Has quotes } \\
\text { by famous } \\
\text { women on } \\
\text { walls } \\
\text {-Gives } \\
\text { harder texts } \\
\text { to some } \\
\text { students } \\
\text {-Practices } \\
\text { are not the } \\
\text { same as in } \\
\text { the } \\
\text { beginning } \\
\text { of her } \\
\text { career }\end{array}$ & \\
\\
\end{tabular} \mid

\subsubsection{Hannah's exercise of agency}

It is clear that Hannah has been an agentive teacher throughout her career, enacting in the classroom that which she values, by which she is convicted, and in which she believes regarding teaching and learning. Table 16 demonstrates the ways in which Hannah's

practices have consistently followed her curricular conceptions, both early in her career and at the time of data collection. 
Table 16. Hannah's Aligned and Misaligned Conceptions and Practices Early in Her Career and at Present

\begin{tabular}{|c|c|c|c|c|}
\hline \multirow[t]{2}{*}{$\begin{array}{l}\text { Time } \\
\text { Period }\end{array}$} & \multicolumn{2}{|c|}{ Aligned Conceptions and Practices } & \multicolumn{2}{|c|}{$\begin{array}{l}\text { Misaligned Conceptions } \\
\text { and Practices }\end{array}$} \\
\hline & Conceptions & Practices & Conceptions & Practices \\
\hline \multirow[b]{2}{*}{ 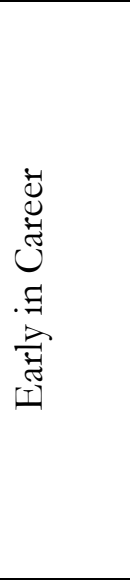 } & $\begin{array}{l}\text { Valued students } \\
\text { meeting and } \\
\text { exceeding grade } \\
\text { level }\end{array}$ & Went over kids' heads & & \\
\hline & $\begin{array}{l}\text { Valued } \\
\text { standardized test } \\
\text { results }\end{array}$ & $\begin{array}{l}\text { Uses: Literary circles; Group } \\
\text { reading protocols; Reciprocal } \\
\text { teaching strategies; Socratic } \\
\text { Seminar; Split classroom; } \\
\text { Small group mini lessons } \\
\text { based on student progress; } \\
\text { Exit tickets; Explicit } \\
\text { instructional modeling }\end{array}$ & & \\
\hline \multirow{3}{*}{ 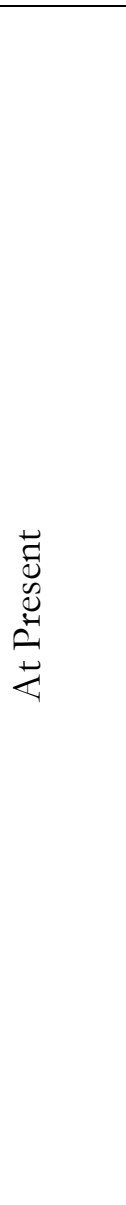 } & $\begin{array}{l}\text { Values students' } \\
\text { building language } \\
\text { skills }\end{array}$ & $\begin{array}{l}\text { Uses: Novel studies; Writing } \\
\text { projects; Research projects; } \\
\text { Whole class novel; Socratic } \\
\text { Seminar; Stations; Direct } \\
\text { instruction with workshop } \\
\text { practice; Read aloud think } \\
\text { aloud modeling; Reciprocal } \\
\text { teaching }\end{array}$ & & \\
\hline & $\begin{array}{l}\text { Values students } \\
\text { making at least a } \\
\text { year's worth of } \\
\text { progress; } \\
\text { Believes students } \\
\text { are capable of } \\
\text { meeting or } \\
\text { exceeding grade } \\
\text { level }\end{array}$ & $\begin{array}{l}\text { Keeps walls clean to help } \\
\text { students to focus; Puts skill } \\
\text { strategy posters on walls }\end{array}$ & & \\
\hline & $\begin{array}{l}\text { Views curriculum } \\
\text { as something } \\
\text { that is not set, } \\
\text { except for the } \\
\text { standards; Values } \\
\text { standards-based } \\
\text { curriculum }\end{array}$ & $\begin{array}{l}\text { Focuses time on the } \\
\text { particulars of lesson design; } \\
\text { Chooses relevant texts for } \\
\text { students }\end{array}$ & & \\
\hline
\end{tabular}




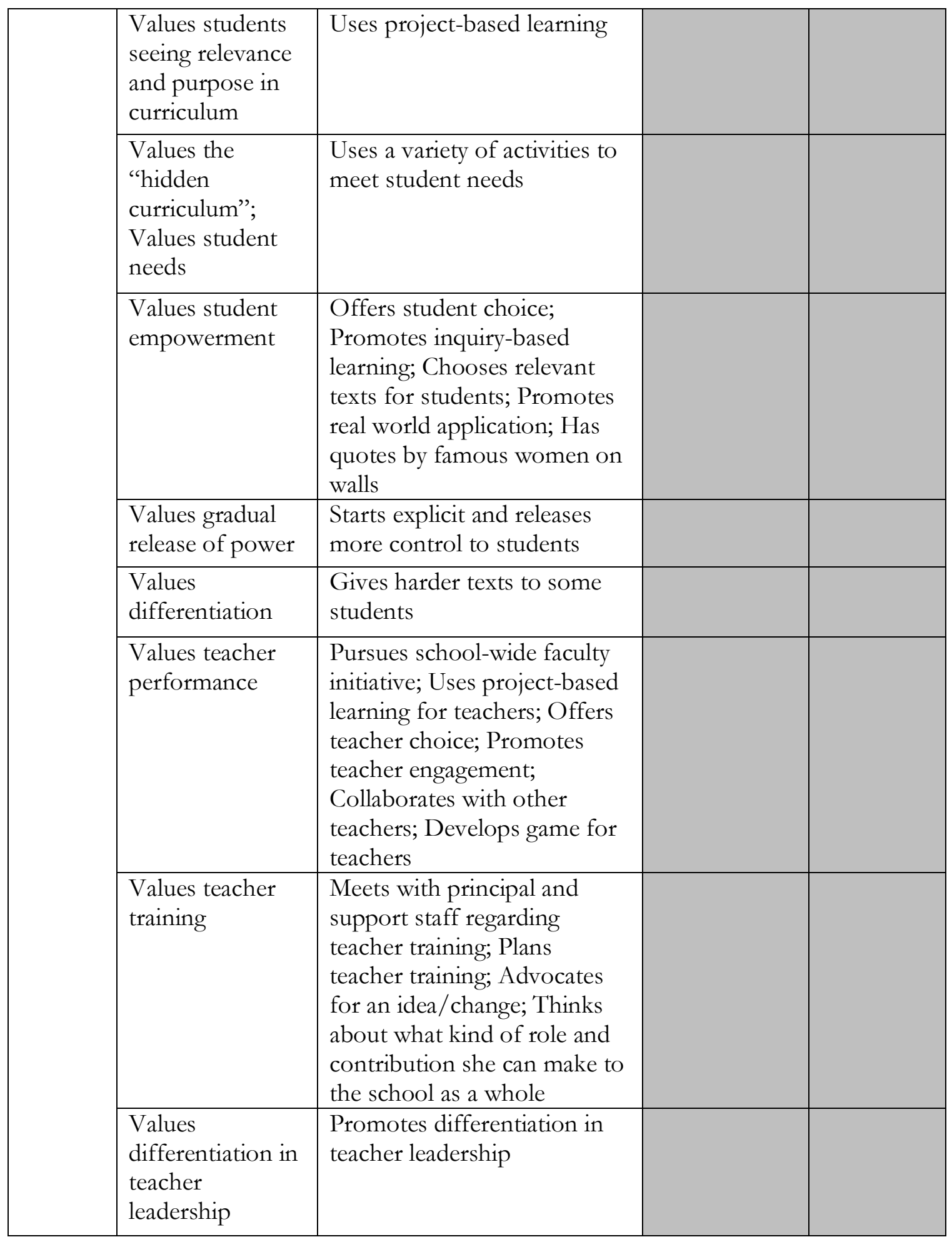




\begin{tabular}{|l|l|l|l|l|}
\hline $\begin{array}{l}\text { Values alignment } \\
\text { of school goals } \\
\text { with professional } \\
\text { development } \\
\text { with teachers' } \\
\text { goals }\end{array}$ & $\begin{array}{l}\text { Plans professional } \\
\text { development curriculum } \\
\text { around school alignment }\end{array}$ & & \\
\cline { 2 - 5 } & $\begin{array}{l}\text { Conceptions of } \\
\text { curriculum are } \\
\text { the same as } \\
\text { before } \\
\text { collaborative }\end{array}$ & $\begin{array}{l}\text { Did not change curriculum } \\
\text { based on collaborative }\end{array}$ & & \\
\hline $\begin{array}{l}\text { Conceptions of } \\
\text { curriculum are } \\
\text { not the same as } \\
\text { in the beginning } \\
\text { of her career }\end{array}$ & $\begin{array}{l}\text { Practices are not the same as } \\
\text { in the beginning of her career }\end{array}$ & & & \\
\hline
\end{tabular}

Hannah's curricular conceptions have changed only slightly from the beginning of her career, in the areas of rigor, habits of planning, and what she prioritizes in the classroom, and her practices have reflected these changes. She was sure to note that these changes did not take place due to her participation in the collaborative.

However, new conceptions and practices surfaced for Hannah during the year in the collaborative regarding teacher leadership and professional development. She was able to more clearly see the needs of her school and the teachers in her school, and to take her gaze off of her own practice in order to advocate for an even greater cause at Whitfield: the practice of all of the other teachers in her building, to the end that students might receive quality instruction in all of their classes. Hannah's values regarding teacher professional development and curriculum in general are reflected in her professional development instructional plan for the coming school year.

The agency that Hannah has experienced throughout her career, both as a teacher and as a teacher leader in her school, can be characterized as structurally transformative; it is 
clear that she has long held to the philosophy that effective curriculum is not to be prepackaged, but comes to be as it is designed by the teacher. Throughout her five-year tenure, Hannah has intentionally designed her lessons, choosing the strategies and texts to use in the classroom. She has not, however, maintained entirely the same conceptions and practices throughout her five years as a teacher, but has allowed for both to change with each year as she learns more fully what it is to be a teacher who is helpful to her students. In this way, she continually expresses agency in keeping with her experiences and changing ideals.

Hannah's structurally transformative agency extends to the arena of teacher leadership. Instead of relying on well-worn professional development techniques and formats, Hannah has taken it upon herself to design professional development pathways for teachers that are differentiated, aligned with other school initiatives, are relevant and engaging to teachers, and reflect best practices.

\subsubsection{Artifactual evidence of Hannah's agency}

Hannah's tentative plan for the professional development pathways mirrors her expressed ideals. On the table (shown below) that she provided as an artifact, she listed the names of the various pathways that would be available to teachers, the texts and topics involved in each pathway, and the likely teacher audience for each one. 


\begin{tabular}{|c|c|c|}
\hline Name & Texts/Topics & Likely Audience \\
\hline Whitfield 101 & $\begin{array}{l}\text { What are best lesson planning } \\
\text { practices using the Whitfield 5? } \\
\text { How can we all build productive, } \\
\text { focused learning environments for our } \\
\text { students? } \\
\text { - What makes WCPS unique from other } \\
\text { districts and what does this mean for } \\
\text { my teaching? (everything from the } \\
\text { history of Larborough to Backpack of } \\
\text { Skills!) }\end{array}$ & $\begin{array}{l}\text { First year teachers } \\
\text { new to a large } \\
\text { urban district }\end{array}$ \\
\hline $\begin{array}{l}\text { Reading } \\
\text { Strategies for } \\
\text { Non-ELA } \\
\text { Teachers }\end{array}$ & $\begin{array}{l}\text { - When and how should I use student } \\
\text { MAPs and reading data? } \\
\text { Content Literacy Strategies } \\
\\
\text { When Kids Can't Read, What } \\
\text { Teachers Can Do }\end{array}$ & $\begin{array}{l}\text { Non-ELA teachers } \\
{ }^{*} \text { Focus on one } \\
\text { content or more } \\
\text { than one? }\end{array}$ \\
\hline Differentiation & $\begin{array}{l}\text { - How can I establish and foster a } \\
\text { Growth Mindset Climate for my } \\
\text { students? } \\
\text { - How can I best collaborate with my } \\
\text { co-teacher? } \\
\text { - How and when should I group } \\
\text { students? } \\
\text { - How can I incorporate Universal } \\
\text { Design in my planning? } \\
\text { - How can I best meet the diverse } \\
\text { needs of my diverse students? }\end{array}$ & $\begin{array}{l}\text { Teachers with at } \\
\text { least two years of } \\
\text { experience }\end{array}$ \\
\hline $\begin{array}{l}\text { Collaboration } \\
\text { Techniques }\end{array}$ & $\begin{array}{l}\text { - What are best practices for using } \\
\text { different Workshop models? } \\
\text { - When and how should I intentionally } \\
\text { group students? } \\
\text { - How can I build in Montessori } \\
\text { strategies? } \\
\text { - Academic Conversations }\end{array}$ & $\begin{array}{l}\text { ECE Teachers } \\
\text { paired with } \\
\text { Coteachers }\end{array}$ \\
\hline
\end{tabular}




\begin{tabular}{|c|c|c|}
\hline $\begin{array}{l}\text { Assessment and } \\
\text { Feedback }\end{array}$ & $\begin{array}{l}\text { - How much feedback do students truly } \\
\text { need? } \\
\text { - } \quad \text { gnd how can we balance and build in } \\
\text { siving meaningful feedback to } \\
\text { students? } \\
\text { - How can we build in opportunities for } \\
\text { students to be constructively critical of } \\
\text { their own work and of each other's } \\
\text { work? } \\
\text { - What is the balance between effort } \\
\text { and skills that we should all be } \\
\text { seeking in our gradebooks? }\end{array}$ & $\begin{array}{l}\text { Teachers who are } \\
\text { looking for ways } \\
\text { to help students } \\
\text { make more } \\
\text { growth }\end{array}$ \\
\hline Technology & Work to become Google-certified & \\
\hline $\begin{array}{l}\text { Teaching } \\
\text { Organization and } \\
\text { Study Skills }\end{array}$ & $\begin{array}{l}\text { When do I need to model and } \\
\text { explicitly teach study skills and } \\
\text { organization? } \\
\text { - How can I scaffold opportunities for } \\
\text { students to improve their study skills? }\end{array}$ & \\
\hline $\begin{array}{l}\text { Building } \\
\text { Independent } \\
\text { Learners }\end{array}$ & $\begin{array}{l}\text { - How can I build in opportunities for } \\
\text { students to take the lead in their own } \\
\text { learning and discussions? } \\
\text { - How can I intentionally incorporate } \\
\text { inquiry-based units and project-based } \\
\text { learning into my curriculum? } \\
\text { - How can I teach students to be more } \\
\text { independent in the classroom and } \\
\text { monitor their own progress? }\end{array}$ & \\
\hline
\end{tabular}

Figure 9. Hannah's Plans for the Pathways Program

This tentative plan for Hannah's pathway project is an expression of structurally transformative agency. Hannah's incentive for this project was dissatisfaction with the current norm for teacher professional development experiences. She chose to break with the norm, implementing a new vision with the blessing and help of the district and her administration.

The various pathways and 'likely audiences' listed on the plan reflect Hannah's value for differentiation and for choice, while the texts and topics show Hannah's desire for professional development to be relevant and engaging; the questions are in first person, addressing areas that are relevant to teachers' particular location in their school and district. 
Hannah's reported ideals for best practices and teacher lesson design, among other values, are readily apparent in her instructional plan.

\subsection{MICHELLE}

Michelle is the final teacher participant in this study, and a science teacher at Norton Middle School. She, like Robert, Sydney, and Hannah, was a mentee in the collaborative during the most recent school year, although she stated more than once that she initially thought that she was joining the collaborative as a mentor.

Michelle has taught for seventeen years. She taught for nine years in another county in the state; for six of those years, she taught middle school science, and for three years she taught Special Education. For the past eight years, Michelle has taught in Washington County, where she has taught middle school science and Special Education, has co-taught math and language arts, and has served as a resource teacher for language arts and math. Currently, she teaches eighth grade science.

Teaching is Michelle's second career, as she spent many years working as the assistant to the owner of a company that ran charitable Bingo halls. When the owner suddenly died when Michelle was in her late twenties, she decided that she wanted to teach. Michelle received a Bachelor of Science degree in Biology and a Bachelor of Science degree in Special Education from two different large, public universities. She received her Master of Arts degree in Instructional Leadership at a large state institution as well. Michelle shared that she pursued this master's degree because she views herself as a leader with a "strong, outgoing personality," and has continually considered the possibility of pursuing a position 
in school administration: "Somebody needs to be in charge. I'm good at it. Why shouldn't it be me?” she said during the interview.

When asked what vision or goals for her instruction guide how and what she teaches, Michelle emphasized relationship building and making sure that students follow expectations. "I think one these two things are in place, teaching the content follows easier," she wrote in the teacher background survey. She noted that she uses the 5e Learning cycle when she teaches. This method involves five steps: engage, explore, explain, elaborate/extend, and evaluate. She seeks to relate what students are learning with "actual, real time, real life events."

When asked to describe her curriculum, Michelle responded, "My curriculum is set by the district." She made it very clear in the teacher background survey and in the interview that she does not design her course curriculum and did not focus on designing her curriculum during her time in the collaborative.

For her innovative design during her participation in the collaborative, Michelle pursued an initiative to garner more parental involvement in her school, especially for parents of students from two neighborhoods that she described as struggling socioeconomically. Michelle hoped that by inviting parents to the school on "Norton Nights," sharing a meal together and listening to parents' questions and concerns, the school could foster a stronger partnership with the parents of those students whom Michelle described as having potential, but who “weren't getting what they needed at home, whether intentionally or unintentionally.” Michelle and a few of her colleagues held two Norton Nights before the school year ended. For each of these nights, they sent flyers to parents with the two designated zip codes to invite them, set up times for the activity bus to pick parents up, and spent time, once parents arrived, eating together, getting to know the 
parents, and asking them questions regarding their school-related experiences and concerns. "And we're going to use those answers to guide us to what parents said would be helpful," Michelle stated in the interview. Only five people came to the first Norton Night, due to a teacher strike that had closed school that day, but around fifty came to the second. Michelle shared that she and her colleagues have plans to continue Norton Nights in the upcoming school year.

\subsubsection{Michelle's curricular conceptions throughout her career}

Like Robert, Michelle claimed that her curricular conceptions and practices had not changed since her early career. Thus, the table below reflects Michelle's reported conceptions and beliefs, which cannot be categorized simply as occurring "before the collaborative" or "during/after the collaborative." The majority of the curricular conceptions and practices reported by Michelle have been consistent throughout her career.

Throughout her career as a teacher, Michelle has valued building relationship with students, student engagement, and student obedience, hoping that students might become better people and learn some of the academic content in the process. Michelle has also been a long-time proponent of Maslow's Hierarchy of Needs, feeling that until people's basic needs, such as food, clothing, and shelter, are met, they will not be willing or able to focus on their less basic needs, like education. Michelle believes that her district's eighth grade science curriculum is especially poor. she was willing to share this sentiment even during the collaborative's Demo Day in May, where she publicly addressed the district Assistant Superintendent, saying, "Mr. Morley, Dr. Morley? ...the eighth-grade content for science is horrible. I'm just gonna be honest. There is no student engagement, there is nothing that is, 
I mean, it's all a lot of facts, figures, and it's...there's nothing to engage them." In spite of this perspective, and her reported belief that she should be designing curriculum, Michelle has felt constrained by the district with regard to her curriculum, believing that the curriculum is set, and that she can do nothing but transmit it to students.

\subsubsection{Michelle's curricular practices throughout her career}

Regarding practices, Michelle stated that she has used the 5e Learning cycle for the past seventeen years. She also noted that she has always sought to build strong relationships with students, to enforce rules and expectations in the classroom, and to engage students in learning. Michelle placed a greater emphasis on relationship and engagement than on rigor; she shared that she regularly tells her students that she hopes they can learn "some science" from her, but that mostly, she hopes that they become better people.

Michelle has criticized the district curriculum in front of her students; she shared in the interview, "I'm honest with the kids. I'm like, 'Kids, I promise you, I will make this as interesting as I can, but it's gonna bore ya. So, but just hang with me, and I promise we'll get through it as fast as we can.”' Because she feels that the eighth-grade prepackaged curriculum is insufficient, she stated that she tries to "fill in" some of the content that is lacking; at the same time, though, Michelle admitted that she had not written a lesson plan in a long time. When I asked her during the interview to send me a lesson plan she had written, she responded, “Okay, I'm going to be honest, I haven't done a lesson plan since, well, in a while. I did them my first year at Mathis, but they were very limited. But then, at Norton, since they send us basically the lesson plans, all, you know, written out?” Michelle also noted that whenever she has innovative ideas for her instruction, she has quickly forgotten them, 
feeling unable to carry them out in her context. At one point during the interview, Michelle shared that her principal would have been willing to support her in any innovations that she undertook; still, she felt unable to pursue them.

Table 17. Michelle's Conceptions and Practices Early in Her Career, Throughout Her Career, and During the Enactment of Her Innovative Design

\begin{tabular}{|c|c|c|c|c|}
\hline $\begin{array}{l}\text { Conceptions } \\
\text { Early in } \\
\text { Teaching } \\
\text { Career }\end{array}$ & $\begin{array}{l}\text { Practices } \\
\text { Early in } \\
\text { Teaching } \\
\text { Career }\end{array}$ & $\begin{array}{c}\text { Conceptions } \\
\text { Consistent } \\
\text { Throughout } \\
\text { Teaching Career }\end{array}$ & $\begin{array}{c}\text { Practices Consistent } \\
\text { Throughout Teaching } \\
\text { Career }\end{array}$ & $\begin{array}{l}\text { Practices During } \\
\text { Enactment of } \\
\text { Innovative Design }\end{array}$ \\
\hline $\begin{array}{l}\text {-Did not see } \\
\text { a need to } \\
\text { build } \\
\text { relationships } \\
\text { with parents } \\
\text { of her } \\
\text { students }\end{array}$ & $\begin{array}{l}\text {-Did not } \\
\text { reach out } \\
\text { to parents } \\
\text { of her } \\
\text { students }\end{array}$ & $\begin{array}{l}\text {-Values } \\
\text { relationship } \\
\text { building (5) } \\
\text {-Values Maslow's } \\
\text { Hierarchy of } \\
\text { Needs (2) } \\
\text {-Believes there is } \\
\text { not flexibility in } \\
\text { the timing of her } \\
\text { content (2) } \\
\text {-Believes she is } \\
\text { constrained by the } \\
\text { district (2) } \\
\text {-Curricular } \\
\text { conceptions have } \\
\text { not changed } \\
\text { during teaching } \\
\text { career } \\
\text {-Values students } \\
\text { learning "some } \\
\text { content" } \\
\text {-Values student } \\
\text { character } \\
\text { development }\end{array}$ & $\begin{array}{l}\text {-Builds relationship } \\
\text { with students (3) } \\
\text {-Curricular practices } \\
\text { have not changed } \\
\text { during career (2) } \\
\text {-Uses 5e method (but } \\
\text { doesn't remember it) } \\
\text { (2) } \\
\text {-Follows expectations } \\
\text { and enforces rules (2) } \\
\text {-Tells students, "I hope } \\
\text { you learn some science } \\
\text { from me" } \\
\text {-Is the giver of } \\
\text { knowledge } \\
\text {-Tells students, "I hope } \\
\text { I can teach you how to } \\
\text { be a better human } \\
\text { being" } \\
\text {-Uses strictly district } \\
\text { curriculum } \\
\text {-Criticizes the district } \\
\text { curriculum in front of } \\
\text { students }\end{array}$ & $\begin{array}{l}\text {-Did not change } \\
\text { curriculum during } \\
\text { collaborative, nor } \\
\text { was she challenged } \\
\text { to do so (8) } \\
\text {-Targeted students } \\
\text { struggling } \\
\text { academically or } \\
\text { behaviorally for } \\
\text { Norton Nights ( } 3 \text { ) } \\
\text {-Created Norton } \\
\text { Nights to engage } \\
\text { parents in students' } \\
\text { school lives (2) } \\
\text {-Plans to } \\
\text { implement changes } \\
\text { suggested at } \\
\text { Norton Nights } \\
\text {-Built relationship } \\
\text { with parents during } \\
\text { collaborative } \\
\text {-Met parents' needs } \\
\text { in order to bring } \\
\text { them to Norton } \\
\text { Nights: bussed } \\
\text { them, fed them, } \\
\text { gave them a voice }\end{array}$ \\
\hline
\end{tabular}




\begin{tabular}{|c|c|c|c|c|}
\hline & & $\begin{array}{l}\text {-Believes her } \\
\text { curriculum is set } \\
\text { by the district } \\
\text {-Believes she } \\
\text { should be } \\
\text { designing } \\
\text { curriculum (with } \\
\text { district-provided } \\
\text { content) } \\
\text {-Believes district- } \\
\text { provided } \\
\text { curriculum is poor } \\
\text {-Values student } \\
\text { engagement } \\
\text {-Values student } \\
\text { obedience }\end{array}$ & $\begin{array}{l}\text {-Forgets about her own } \\
\text { curricular design ideas } \\
\text { because she feels too } \\
\text { constricted to entertain } \\
\text { them } \\
\text {-Has not written a } \\
\text { lesson plan in a long } \\
\text { time, because she uses } \\
\text { the district's lesson } \\
\text { plans } \\
\text {-Teaches what she feels } \\
\text { she has to (in scope } \\
\text { and sequence) } \\
\text {-Tries to "fill in" } \\
\text { material that she feels is } \\
\text { lacking in the district } \\
\text { curriculum } \\
\text {-Tells students they can } \\
\text { talk about any topic } \\
\text { they want } \\
\text {-Had student write a } \\
\text { rap } \\
\text {-Promotes real world } \\
\text { application }\end{array}$ & $\begin{array}{l}\text {-Chose not to } \\
\text { innovate in her } \\
\text { curriculum during } \\
\text { the collaborative } \\
\text { even though her } \\
\text { principal made it } \\
\text { clear that she would } \\
\text { support it }\end{array}$ \\
\hline
\end{tabular}

Michelle shared at the Demo Day that the feeling of being "stuck" with the prepackaged curriculum was one of the incentives for her pursuit of "Norton Nights." Following her statement about the lack of engagement to be found in the science curriculum, Michelle continued, "So, there's nothing I felt I could do for that. So, we went a different route, and we went to, 'How can we engage the parents?' So, we created something called Norton Nights." During the pursuit of Norton Nights, Michelle majored in 
relationship-building with parents and students, sought to meet the families' basic needs for transportation and food, and gave parents the time and space to raise concerns and questions regarding their child's school experience. In this way, Michelle experienced what she views as the lone change in her conceptions and practice from the beginning of her career to the present time; she did not seek to involve parents in the past, believing that this was not needed. Now, she sees parental involvement as a bridge to students' academic and behavioral success, and has spent a significant amount of time, money, and resources pursuing their involvement.

\subsubsection{Michelle's exercise of agency}

The curricular conceptions to which Michelle has held throughout her career have aligned in many ways with her classroom practice: she values relationship building, so she builds relationships with students; she values student engagement, so she uses the $5 \mathrm{e}$ Learning cycle, tries to involve real world application of content, she sometimes allows for creative means of assessment, like having students write raps, and gives students freedom to talk in class about topics that interest them; she values student obedience, so she places a heavy emphasis on the following of rules and expectations.

Michelle's practices with regard to the district curriculum have also reflected her beliefs: as she believes that her curriculum is set firmly by the district, she uses this curriculum alone; she does not feel there is any flexibility in the timing of her instruction, so she follows, precisely, the scope and sequence provided by the district; she feels constrained by the district curriculum, so she criticizes it in front of her students; and she believes the district curriculum is poor, so she tries to "fill in" material that she feels is lacking in it. 
Table 18. Michelle's Aligned and Misaligned Conceptions and Practices Early in Her Teaching Career, Throughout Her Teaching Career, and During the Enactment of Her Instructional Design

\begin{tabular}{|c|c|c|c|c|}
\hline \multirow{2}{*}{$\begin{array}{l}\text { Time } \\
\text { Period }\end{array}$} & \multicolumn{2}{|c|}{ Aligned Conceptions and Practices } & \multicolumn{2}{|c|}{ Misaligned Conceptions and Practices } \\
\hline & Conceptions & Practices & Conceptions & Practices \\
\hline 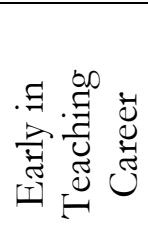 & $\begin{array}{l}\text { Did not see a need } \\
\text { to build } \\
\text { relationship with } \\
\text { parents of her } \\
\text { students }\end{array}$ & $\begin{array}{l}\text { Did not reach } \\
\text { out to parents } \\
\text { of her students }\end{array}$ & & \\
\hline \multirow{4}{*}{ 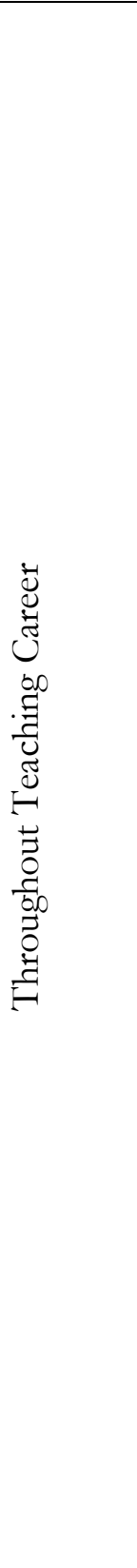 } & $\begin{array}{l}\text { Curricular } \\
\text { conceptions have } \\
\text { remained the same } \\
\text { throughout career }\end{array}$ & $\begin{array}{l}\text { Curricular } \\
\text { practices have } \\
\text { remained the } \\
\text { same } \\
\text { throughout } \\
\text { career }\end{array}$ & $\begin{array}{l}\text { Believes she should } \\
\text { be designing } \\
\text { curriculum (with } \\
\text { district-provided } \\
\text { content) }\end{array}$ & $\begin{array}{l}\text { Forgets about her } \\
\text { curricular design } \\
\text { plans because she } \\
\text { feels too } \\
\text { constricted to } \\
\text { entertain them; } \\
\text { Has not written a } \\
\text { lesson plan in a } \\
\text { long time, because } \\
\text { she uses the } \\
\text { district's lesson } \\
\text { plans; Curricular } \\
\text { approach has not } \\
\text { changed during } \\
\text { career }\end{array}$ \\
\hline & $\begin{array}{l}\text { Values relationship } \\
\text { building }\end{array}$ & $\begin{array}{l}\text { Builds } \\
\text { relationships } \\
\text { with students }\end{array}$ & $\begin{array}{l}\text { Believes district- } \\
\text { provided } \\
\text { curriculum is poor }\end{array}$ & $\begin{array}{l}\text { Uses strictly } \\
\text { district curriculum }\end{array}$ \\
\hline & $\begin{array}{l}\text { Values student } \\
\text { engagement }\end{array}$ & $\begin{array}{l}\text { Tells students } \\
\text { they can talk } \\
\text { about any } \\
\text { topic they } \\
\text { want; Had } \\
\text { student write a } \\
\text { rap; Promotes } \\
\text { real world } \\
\text { application; } \\
\text { Uses 5e } \\
\text { method (but } \\
\text { doesn't } \\
\text { remember it) }\end{array}$ & $\begin{array}{l}\text { Values student } \\
\text { engagement }\end{array}$ & $\begin{array}{l}\text { Shares that the } \\
\text { district curriculum } \\
\text { has "no } \\
\text { engagement," but } \\
\text { uses it, as is, } \\
\text { anyway }\end{array}$ \\
\hline & $\begin{array}{l}\text { Values student } \\
\text { obedience }\end{array}$ & $\begin{array}{l}\text { Follows } \\
\text { expectations } \\
\text { and enforces } \\
\text { rules }\end{array}$ & & \\
\hline
\end{tabular}




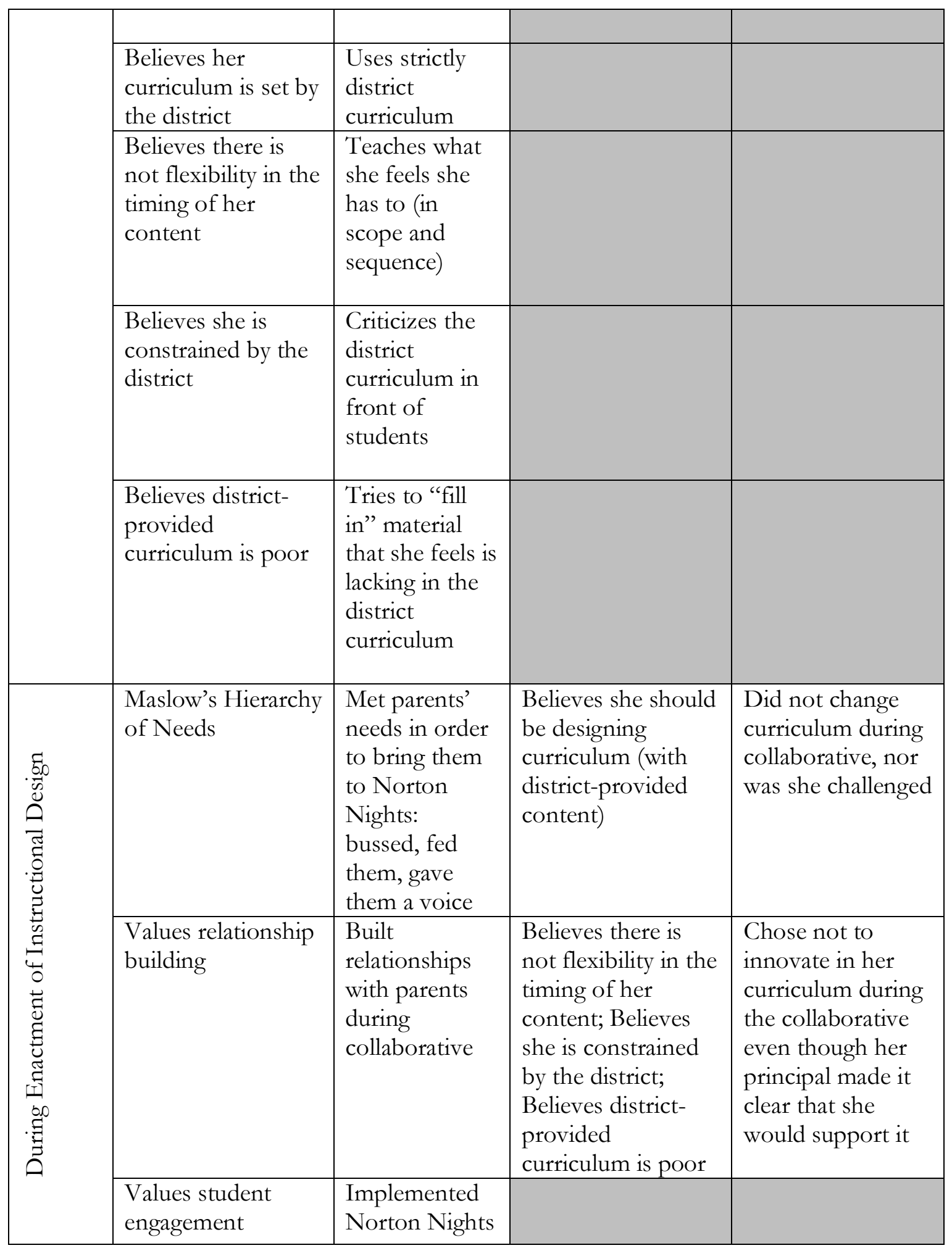




\begin{tabular}{|l|l|l|l|l|}
\hline Values student & Targeted & \\
obedience & students & & \\
& struggling & & \\
& academically or & & \\
& behaviorally & & \\
& for Norton & & \\
& Nights & & \\
\hline
\end{tabular}

On the other hand, Michelle has also experienced misalignment between her curricular beliefs and practices throughout her career. She believes that she should and could be designing curriculum for her students. "I really just need you [the district] to give me the content, and I'll figure out what's going to be best for mine," she stated during the interview. Nonetheless, she has not written a lesson plan in years, and she does not allow her innovative ideas to be enacted in her classroom; in fact, she noted that she forgets these ideas as soon as she has them, so beholden she feels to transmit the prepackaged curriculum. Moreover, Michelle believes that the district-provided curriculum is poor and involves no engagement of students, but she continues to use it, as is, anyway.

Even her participation in the collaborative did not move Michelle to innovate in her classroom curriculum. Her assistant principal told her during the collaborative, "[C]hange the curriculum. Do what you want to do," and Michelle felt that her principal "would've done everything in her power to facilitate that for [her]," and yet, Michelle did not make changes in her classroom. "[T] hat's not really where we took the program," she said. Michelle's desire for greater flexibility and student engagement have not yet moved her to make changes in her classroom practice.

Interestingly, Table 18 above demonstrates Michelle's willingness to innovate outside of her classroom, but not inside of it. During the enactment of her instructional design, Michelle resisted the encouragement to focus on her classroom, instead pursuing innovation 
with regard to parental involvement in the school. Michelle expressed structurally transformative agency in this endeavor, as her enactment of the design aligned with her values regarding needs, relationship building, student engagement, and student obedience, and as she and her colleagues built a program that had never been before.

Apart from her pursuit of Norton Nights, Michelle's reported conceptions and practices are reflective of structurally reproductive agency, and in some areas, no agency at all. Where Michelle's beliefs and practices have aligned throughout her career, the alignment has been in favor of maintaining previously existing structures and mandates, and where they have misaligned, the misalignment has likewise favored the status quo and an unwillingness to go beyond what is safe and known.

\subsubsection{Artifactual evidence of Michelle’s agency}

As artifacts, Michelle provided the Norton Night flyer that was sent to parents, a document that listed the questions that were asked to parents on the first Norton Night, and the unit three teacher guide for WCPS' eighth grade science curriculum.

The flyer confirms what Michelle shared about Norton Nights regarding the format and purpose. "You are invited to an informal community forum to help foster academic success within Norton," it reads, offering the date, place, time, and her contact information. The activity bus pick-up times and places are listed on the flyer, as well as the note that dinner and door prizes would be provided for parents, and activities and games for the children in attendance.

The questionnaire is reflective of Michelle's reported intentions for Norton Nights. She stated a desire for these nights to help parents to feel like they have a voice in their 
child's school experience, and to help teachers and staff receive feedback regarding what might help struggling students to succeed. The questions asked to parents in attendance were the following:

1) If you had a million dollars, how would you use that to make your child academically successful?

2) What is the worst thing we, as teachers, could do that would prevent your child from being successful?

3) Are there specific needs that school could help with when it comes to your student? Ex. Internet, pencils, paper, materials for projects...

4) If we had after school tutoring, would you let them stay? If not, what prevents them from staying?

5) How can we make your child accountable?

6) Would you come to future meetings? What could we do at these meetings that would help foster the success of your student?

Although perhaps offensive, as several of these questions clearly articulate a deficit perspective of students, these questions align with the stated purpose of Norton Nights, as they are related to students' academic and behavioral success.

Finally, the prepackaged unit plan that Michelle provided was comprised of 204 pages, and revealed evidence that indeed, Michelle would never have to create a lesson plan if she did not desire to. The unit plan is very detailed, providing teachers with the state standards that are met in each lesson, the number of days the lesson should take, materials needed for students, advance preparation that the teacher should undertake, and step-bystep procedures, including what the teachers should say to students at each turn. While this artifact does not evidence alignment or misalignment between Michelle's beliefs and 
practices, it does demonstrate that Michelle is indeed able to transmit all of her lessons from the prepackaged district curriculum, just as she feels bound to do.

\subsection{SUMMARY OF TEACHER PARTICIPANTS' AGENCY}

Table 19. Summary of the Teacher Participants' Exercise of Agency

\begin{tabular}{|c|c|c|c|c|c|c|}
\hline Teacher & $\begin{array}{c}\text { Lack of } \\
\text { Agency } \\
\text { Before } \\
\text { Collaborative }\end{array}$ & $\begin{array}{c}\text { Structurally } \\
\text { Reproductive } \\
\text { Agency } \\
\text { Before } \\
\text { Collaborative } \\
\end{array}$ & $\begin{array}{c}\text { Structurally } \\
\text { Transformative } \\
\text { Agency Before } \\
\text { Collaborative }\end{array}$ & $\begin{array}{c}\text { Lack of } \\
\text { Agency } \\
\text { During/After } \\
\text { Collaborative }\end{array}$ & $\begin{array}{c}\text { Structurally } \\
\text { Reproductive } \\
\text { Agency } \\
\text { During/After } \\
\text { Collaborative }\end{array}$ & $\begin{array}{c}\text { Structurally } \\
\text { Transformative } \\
\text { Agency } \\
\text { During/After } \\
\text { Collaborative }\end{array}$ \\
\hline Tami & & $\mathrm{x}$ & & & & $\mathrm{x}$ \\
\hline Kellen & $\mathrm{x}$ & & & & & $\mathrm{x}$ \\
\hline Walt & & $\mathrm{x}$ & & & & $\mathrm{x}$ \\
\hline Robert & & $\mathrm{x}$ & & $\begin{array}{c}\mathrm{x} \\
\text { (during } \\
\text { enactment } \\
\text { of } \\
\text { innovative } \\
\text { design) }\end{array}$ & $\begin{array}{c}\mathrm{x} \\
\text { (in everyday } \\
\text { classroom } \\
\text { practice) }\end{array}$ & $\begin{array}{c}\mathrm{x} \\
\text { (during } \\
\text { enactment of } \\
\text { innovative } \\
\text { design) }\end{array}$ \\
\hline Sydney & & $x$ & & & & $x$ \\
\hline Hannah & & & $\mathrm{x}$ & & & $\mathrm{x}$ \\
\hline Michelle & $\mathrm{x}$ & $\mathrm{x}$ & & $\begin{array}{c}\mathrm{x} \\
\text { (in everyday } \\
\text { classroom } \\
\text { practice) }\end{array}$ & $\begin{array}{c}\mathrm{x} \\
\text { (in everyday } \\
\text { classroom } \\
\text { practice) }\end{array}$ & $\begin{array}{c}\mathrm{x} \\
\text { (during } \\
\text { enactment of } \\
\text { innovative } \\
\text { design) }\end{array}$ \\
\hline
\end{tabular}

Table 19 summarizes the trends in agency that the seven teacher participants experienced during the time period before their participation in the collaborative and during and after their participation. All of the teacher participants (save for Hannah, who has experienced structurally transformative agency throughout her career), experienced a shift in their exercise of agency from the time before their participation in the collaborative to the time during and after their participation.

For several teachers, there was a clean shift from structurally reproductive agency to structurally transformative agency, as teachers moved from reproducing the materials and 
mandates of others to designing curriculum or schoolwide programs for themselves, as their beliefs, values and convictions changed. This was the case for Tami, Walt, and Sydney.

Kellen moved from being a teacher who had struggled to exercise agency, as she had habitually followed prepackaged curricula and the plans of others, in spite of her more progressive ideas, to a teacher able to enact her curricular conceptions in the innovative design of her classroom curriculum.

Finally, Robert and Michelle present interesting cases, as they largely claimed no change in their structurally reproductive beliefs and practices in their everyday classroom practice. For Robert, the innovative instructional design that he created and enacted during the collaborative served as an experiment, and in some ways, he acted contrary to his curricular beliefs in enacting the design, while in others, he was able to align his curricular conceptions and practices through the plan. Thus, he experienced both a lack of agency in the enactment of his design, and, for the first time, structurally transformative agency, though it seems as though structurally reproductive agency will continue to be the norm in his classroom practice.

For Michelle, a simultaneous lack of agency and structurally reproductive agency have characterized her seventeen years of teaching; a lack of agency, in that she feels that she should be more innovative in some ways, but does not choose to innovate in the classroom; and structurally reproductive agency, in that her practice of using only prepackaged curriculum is in keeping with many of her other curricular conceptions. During the collaborative, Michelle claimed that there was no change in her instructional classroom practices; however, with the design of her parental involvement initiative, Michelle was able to experience structurally transformative agency, albeit outside of her classroom. 
TRANSFORMATIVE AGENCY

Teacher participants in this study attributed their curricular conceptions, practices, and growth in agency to various influences. In this section, I highlight the influences that teachers reported as supporting their exercise of structurally transformative agency and constricting their exercise of structurally transformative agency. I also note those influences that threatened to constrict structurally transformative agency for teachers, but did not, as well as the influences that could have functioned to support teachers' structurally transformative agency, but did not.

Because this study is mostly concerned with the exercise of structurally transformative agency, the influences to which I call attention here are those that teachers reported to have increased or decreased their structurally transformative agency, and not their structurally reproductive agency. While I coded all reported influences on teachers' curricular conceptions and practices (these being accounted for in Table 20), I take up the influences that related to structurally transformative agency.

Table 20 shows all of the influences for which I coded during analysis, with a number of influences being iterational in nature, practical-evaluative, and projective. I also coded for the influences of personal and professional identity and participation in the collaborative, as these did not fit cleanly into the dimensions designated by Priestley et al. (2013). 
In total, I coded 111 excerpts that revealed iterational influences, 219 excerpts in which teachers pointed to practical-evaluative influences on their curricular conceptions and practices, and 123 excerpts in which teachers mentioned projective influences.

The influences highlighted in gray are those with an average of at least five code applications per participant. These are the nine codes that I take up in the findings. I uncover how these nine codes functioned to support or constrict teachers' structurally transformative agency, as well as those that threatened to constrict it, but did not, and those that could have supported teachers' structurally transformative agency, but did not.

Table 20. Number of Code Applications Per Participant: Influences on Curricular Conceptions and Practices

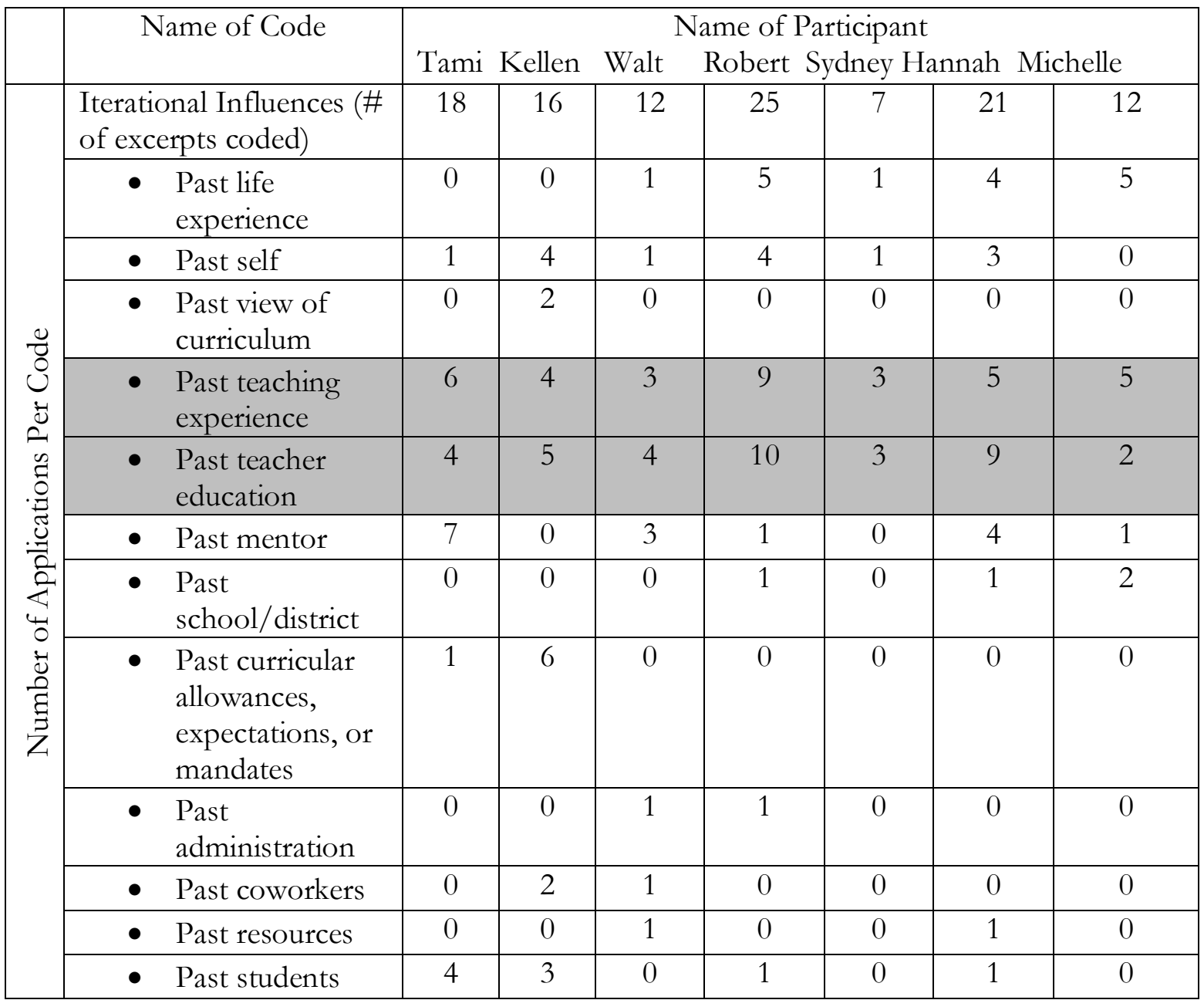




\begin{tabular}{|c|c|c|c|c|c|c|c|}
\hline $\begin{array}{l}\text { Practical-Evaluative } \\
\text { Influences (\# of } \\
\text { excerpts coded) }\end{array}$ & 21 & 41 & 21 & 54 & 26 & 23 & 33 \\
\hline - Current self & 1 & 7 & 4 & 3 & 4 & 0 & 3 \\
\hline $\begin{array}{ll}\text { - } & \text { Current } \\
\text { community }\end{array}$ & 0 & 1 & 0 & 8 & 1 & 0 & 3 \\
\hline - Current mentor & 0 & 1 & 0 & 0 & 0 & 0 & 0 \\
\hline $\begin{array}{ll}- & \text { Current } \\
\text { school/district }\end{array}$ & 0 & 2 & 1 & 10 & 1 & 6 & 11 \\
\hline $\begin{array}{l}\text { - Current } \\
\text { curricular } \\
\text { allowances, } \\
\text { expectations, or } \\
\text { mandates } \\
\end{array}$ & 4 & 10 & 6 & 14 & 5 & 3 & 9 \\
\hline $\begin{array}{ll}\text { - } & \text { Current } \\
\text { administration }\end{array}$ & 12 & 4 & 6 & 12 & 5 & 5 & 4 \\
\hline $\begin{array}{ll}\text { - } & \text { Current } \\
\text { coworkers }\end{array}$ & 5 & 12 & 6 & 9 & 3 & 7 & 1 \\
\hline $\begin{array}{ll}\text { - } & \text { Current } \\
& \text { resources } \\
\end{array}$ & 1 & 0 & 2 & 4 & 2 & 3 & 8 \\
\hline - Current students & 2 & 14 & 2 & 19 & 14 & 3 & 9 \\
\hline $\begin{array}{l}\text { Projective Influences (\# } \\
\text { of excerpts coded) }\end{array}$ & 19 & 16 & 15 & 25 & 21 & 14 & 13 \\
\hline - Goals for self & 0 & 1 & 5 & 6 & 7 & 0 & 1 \\
\hline $\begin{array}{l}\text { - Goals for } \\
\text { school/district }\end{array}$ & 0 & 0 & 0 & 2 & 0 & 5 & 1 \\
\hline $\begin{array}{l}\text { - Goals for } \\
\text { curriculum }\end{array}$ & 1 & 7 & 0 & 0 & 2 & 1 & 0 \\
\hline $\begin{array}{l}\text { - Goals for } \\
\text { students }\end{array}$ & 18 & 13 & 12 & 17 & 18 & 10 & 12 \\
\hline $\begin{array}{l}\text { - Other } \\
\text { orientations } \\
\text { toward the } \\
\text { future }\end{array}$ & 0 & 1 & 0 & 7 & 0 & 0 & 0 \\
\hline $\begin{array}{l}\text { Influence of Personal } \\
\text { and Professional } \\
\text { Identity }\end{array}$ & 1 & 25 & 10 & 13 & 2 & 2 & 10 \\
\hline $\begin{array}{l}\text { Influence of the } \\
\text { Collaborative }\end{array}$ & 14 & 15 & 10 & 11 & 11 & 9 & 6 \\
\hline
\end{tabular}

Table 21 shows influences that were coded during analysis, but will not be addressed further in this chapter. In a qualitative study, even one code application could be 
consequential. However, I chose to focus in this chapter on the most robust codes because of their representativeness. Because I coded for all influences on teachers' conceptions and practices, and not merely supportive or constrictive influences, I hoped that the most robust codes would offer insight that would allow me to more effectively compare teachers' experiences across cases. Moreover, these nine codes represent areas in which teacher education and/or professional development initiatives could have an impact.

Table 21. Codes Not Addressed in Findings

\begin{tabular}{|c|c|c|c|c|c|c|c|c|c|}
\hline & \multirow[t]{2}{*}{ Name of Code } & \multicolumn{7}{|c|}{ Name of Participant } & \\
\hline & & Tami & Kellen & Walt & Robert & Sydney & Hannah & Michelle & \\
\hline \multirow{17}{*}{ 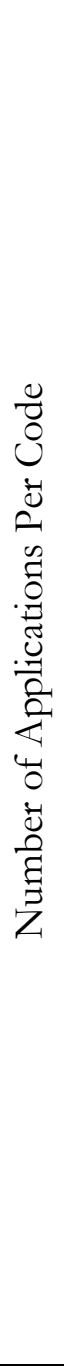 } & $\begin{array}{l}\text { Past life } \\
\text { experience }\end{array}$ & 0 & 0 & 1 & 5 & 1 & 4 & 5 & 5 \\
\hline & Past self & 1 & 4 & 1 & 4 & 1 & 3 & & 0 \\
\hline & $\begin{array}{l}\text { Past view of } \\
\text { curriculum }\end{array}$ & 0 & 2 & 0 & 0 & 0 & 0 & & 0 \\
\hline & Past mentor & 7 & 0 & 3 & 1 & 0 & 4 & 1 & 1 \\
\hline & $\begin{array}{l}\text { Past } \\
\text { school/district }\end{array}$ & 0 & 0 & 0 & 1 & 0 & 1 & 2 & 2 \\
\hline & $\begin{array}{l}\text { Past curricular } \\
\text { allowances, } \\
\text { expectations, or } \\
\text { mandates }\end{array}$ & 1 & 6 & 0 & 0 & 0 & 0 & 0 & 0 \\
\hline & $\begin{array}{l}\text { Past } \\
\text { administration }\end{array}$ & 0 & 0 & 1 & 1 & 0 & 0 & 0 & 0 \\
\hline & Past coworkers & 0 & 2 & 1 & 0 & 0 & 0 & 0 & 0 \\
\hline & Past resources & 0 & 0 & 1 & 0 & 0 & 1 & 0 & 0 \\
\hline & Past students & 4 & 3 & 0 & 1 & 0 & 1 & 0 & 0 \\
\hline & Current self & 1 & 7 & 4 & 3 & 4 & 0 & 3 & 3 \\
\hline & $\begin{array}{l}\text { Current } \\
\text { community }\end{array}$ & 0 & 1 & 0 & 8 & 1 & 0 & 3 & 3 \\
\hline & Current mentor & 0 & 1 & 0 & 0 & 0 & 0 & 0 & 0 \\
\hline & $\begin{array}{l}\text { Current } \\
\text { school/district }\end{array}$ & 0 & 2 & 1 & 10 & 1 & 6 & 11 & 1 \\
\hline & $\begin{array}{l}\text { Current } \\
\text { resources }\end{array}$ & 1 & 0 & 2 & 4 & 2 & 3 & 8 & 8 \\
\hline & Goals for self & 0 & 1 & 5 & 6 & 7 & 0 & 1 & 1 \\
\hline & $\begin{array}{l}\text { Goals for } \\
\text { school/district }\end{array}$ & 0 & 0 & 0 & 2 & 0 & 5 & 1 & 1 \\
\hline
\end{tabular}




\begin{tabular}{|l|l|l|l|l|l|l|l|l|}
\hline & $\begin{array}{l}\text { Goals for } \\
\text { curriculum }\end{array}$ & 1 & 7 & 0 & 0 & 2 & 1 & 0 \\
\hline $\begin{array}{l}\text { Other } \\
\text { orientations } \\
\text { toward the } \\
\text { future }\end{array}$ & 0 & 1 & 0 & 7 & 0 & 0 & 0 \\
\hline
\end{tabular}

Table 22 highlights the nine codes that are addressed in the findings regarding the influences on teachers' structurally transformative agency. These codes were applied to the data an average of at least five times per participant, providing robust data.

Table 22. Codes Addressed in Findings

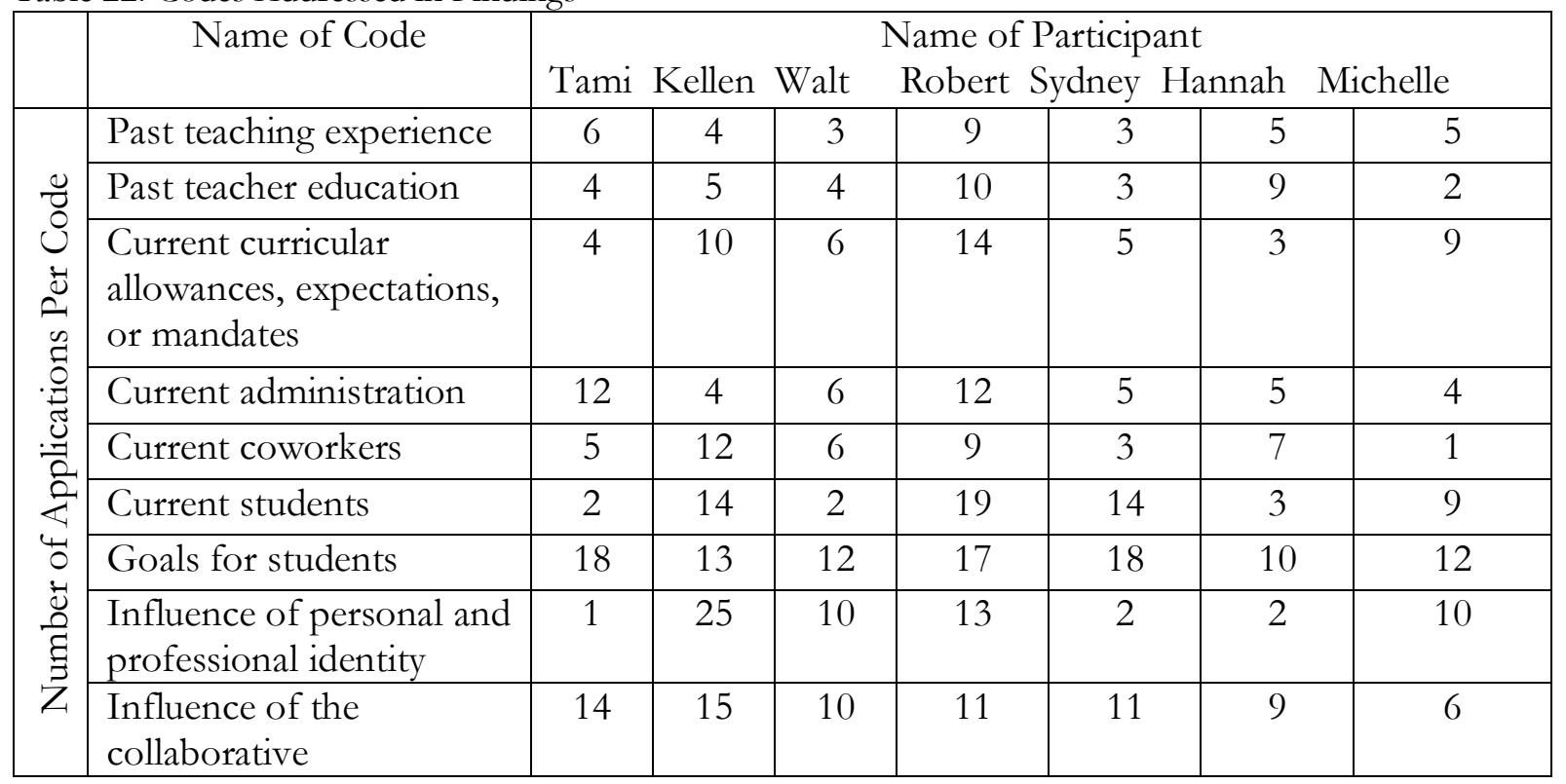

Table 23 orients the reader to the rest of the chapter, as each of its four main columns represents the four main findings sections. First, I address influences that teachers perceived as supporting their structurally transformative agency and innovation. Next, I highlight the influences that were potentially constrictive to teachers' structurally transformative agency, but did not constrain it. I then detail the influences that were shown 
to hinder teachers' structurally transformative agency, focusing only on Robert and Michelle, because they do not exercise structurally transformative agency in their everyday classroom practice. Finally, I describe the influences that were potentially supportive of teachers' structurally transformative agency, but were not perceived by teachers as supportive, or were not taken up by teachers to the end of exercising greater structurally transformative agency.

Table 23. Supportive and Constrictive Influences on Teacher Participants' Structurally Transformative Agency

\begin{tabular}{|c|c|c|c|c|}
\hline Name & $\begin{array}{l}\text { Supportive Influences on } \\
\text { Teachers' Structurally } \\
\text { Transformative Agency }\end{array}$ & $\begin{array}{c}\text { Potentially } \\
\text { Constrictive } \\
\text { Influences on } \\
\text { Teachers' Structurally } \\
\text { Transformative } \\
\text { Agency: }\end{array}$ & \begin{tabular}{|} 
Constrictive \\
Influences on \\
Teachers' \\
Structurally \\
Transformative \\
Agency
\end{tabular} & $\begin{array}{c}\text { Potentially Supportive } \\
\text { Influences on } \\
\text { Teachers' Structurally } \\
\text { Transformative } \\
\text { Agency: }\end{array}$ \\
\hline Tami & $\begin{array}{l}\text {-Past teaching experience } \\
\text {-Past teacher education } \\
\text {-Current allowances } \\
\text {-Current administration } \\
\text {-Current coworkers } \\
\text {-Goals for students } \\
\text {-The collaborative }\end{array}$ & -Current students & -None & $\begin{array}{l}\text {-Personal and } \\
\text { professional identity }\end{array}$ \\
\hline Kellen & $\begin{array}{l}\text {-Current allowances } \\
\text {-Current administration } \\
\text {-Current coworkers } \\
\text {-Current students } \\
\text {-Goals for students } \\
\text {-Personal and } \\
\text { professional identity } \\
\text {-The collaborative }\end{array}$ & $\begin{array}{l}\text {-Past teaching } \\
\text { experience } \\
\text {-Past teacher } \\
\text { education } \\
\text {-Current coworkers } \\
\text {-Current students }\end{array}$ & -None & -None \\
\hline Walt & $\begin{array}{l}\text {-Current allowances } \\
\text {-Current administration } \\
\text {-Current coworkers } \\
\text {-Goals for students } \\
\text {-The collaborative }\end{array}$ & $\begin{array}{l}\text {-Past teaching } \\
\text { experience } \\
\text {-Current students } \\
\text {-Personal and } \\
\text { professional identity }\end{array}$ & -None & $\begin{array}{l}\text {-Past teacher } \\
\text { education }\end{array}$ \\
\hline Robert & $\begin{array}{l}\text {-Goals for students } \\
\text {-The collaborative }\end{array}$ & -None & $\begin{array}{l}\text {-Past teaching } \\
\text { experience } \\
\text {-Past teacher } \\
\text { Education } \\
\text {-Current } \\
\text { coworkers }\end{array}$ & $\begin{array}{l}\text {-Current allowances } \\
\text {-Current } \\
\text { administration }\end{array}$ \\
\hline
\end{tabular}




\begin{tabular}{|c|c|c|c|c|}
\hline & & & $\begin{array}{l}\text {-Current } \\
\text { students } \\
\text {-Personal and } \\
\text { professional } \\
\text { identity }\end{array}$ & \\
\hline Sydney & $\begin{array}{l}\text {-Past teaching experience } \\
\text {-Past teacher education } \\
\text {-Current allowances } \\
\text {-Current administration } \\
\text {-Current coworkers } \\
\text {-Current students } \\
\text {-Goals for students } \\
\text {-Personal and } \\
\text { professional identity } \\
\text {-The collaborative }\end{array}$ & -Current students & -None & -None \\
\hline Hannah & $\begin{array}{l}\text {-Past teaching experience } \\
\text {-Past teacher education } \\
\text {-Current allowances } \\
\text {-Current administration } \\
\text {-Current coworkers } \\
\text {-Goals for students } \\
\text {-The collaborative }\end{array}$ & $\begin{array}{l}\text {-Current coworkers } \\
\text {-Current students }\end{array}$ & -None & $\begin{array}{l}\text {-Personal and } \\
\text { professional identity }\end{array}$ \\
\hline Michelle & $\begin{array}{l}\text {-Goals for students } \\
\text {-The collaborative }\end{array}$ & -Current students & $\begin{array}{l}\text {-Current } \\
\text { allowances } \\
\text {-Personal and } \\
\text { professional } \\
\text { identity }\end{array}$ & $\begin{array}{l}\text {-Past teaching } \\
\text { experience } \\
\text {-Current allowances } \\
\text {-Current } \\
\text { administration } \\
\text {-Current coworkers } \\
\text {-Personal and } \\
\text { professional identity }\end{array}$ \\
\hline
\end{tabular}

\subsection{INFLUENCES THAT SUPPORTED TEACHERS' STRUCTURALLY}

\section{TRANSFORMATIVE AGENCY}

Table 24 displays the influences that the teacher participants perceived to have positively impacted their structurally transformative agency. Teachers' perceptions of the supportive impact of these influences are described in this section. In this section, only the experiences of those teachers who reported being impacted in a positive way by any given 
influence are included; this is because an influence may have been perceived as positively impacting agency for one teacher, while being perceived negatively or as inconsequential by another.

Table 24. Influences that Supported Teacher Participants' Structurally Transformative Agency

\begin{tabular}{|c|c|c|c|c|c|c|c|c|}
\hline & \multirow[t]{2}{*}{ Name of Code } & \multicolumn{7}{|c|}{ Name of Participant } \\
\hline & & Tami & Kellen & Walt & Robert & Sydney & Hannah & Michelle \\
\hline \multirow{9}{*}{ 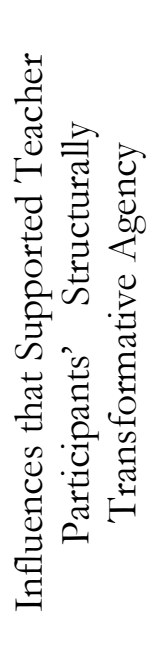 } & $\begin{array}{l}\text { Past teaching } \\
\text { experience }\end{array}$ & $\mathrm{x}$ & & & & $\mathrm{x}$ & $\mathrm{x}$ & \\
\hline & $\begin{array}{l}\text { Past teacher } \\
\text { education }\end{array}$ & $\mathrm{x}$ & & & & $\mathrm{x}$ & $\mathrm{x}$ & \\
\hline & Current allowances & $\mathrm{x}$ & $\mathrm{x}$ & $\mathrm{x}$ & & $\mathrm{x}$ & $\mathrm{x}$ & \\
\hline & $\begin{array}{l}\text { Current } \\
\text { administration }\end{array}$ & $\mathrm{x}$ & $\mathrm{x}$ & $\mathrm{x}$ & & $\mathrm{x}$ & $\mathrm{x}$ & \\
\hline & Current coworkers & $\mathrm{x}$ & $\mathrm{x}$ & $\mathrm{x}$ & & $\mathrm{x}$ & $\mathrm{x}$ & \\
\hline & Current students & & $\mathrm{x}$ & & & $\mathrm{x}$ & & \\
\hline & Goals for students & $\mathrm{x}$ & $\mathrm{x}$ & $\mathrm{x}$ & $\mathrm{x}$ & $\mathrm{x}$ & $\mathrm{x}$ & $x$ \\
\hline & $\begin{array}{l}\text { Personal and } \\
\text { professional } \\
\text { identity }\end{array}$ & & $\mathrm{x}$ & & & $\mathrm{x}$ & & \\
\hline & The collaborative & $\mathrm{x}$ & $\mathrm{x}$ & $x$ & $\mathrm{x}$ & $\mathrm{x}$ & $\mathrm{x}$ & $x$ \\
\hline
\end{tabular}

\subsubsection{Iterational influences: Past teaching experience}

Tami, Sydney, and Hannah reported their past teaching experience as a positive influence on their expression of structurally transformative agency.

Tami continually referenced her experience as a teacher as foundational to her willingness and confidence to deviate from the prepackaged curriculum, seeing it "more as a guide than a mandate." She believes that the more experienced a teacher is, the more they are able to make their curriculum their own. This has been the case for her. She shared, "Being able to understand students and know what I need to do for them has really let me 
feel more comfortable with, okay, this [the prescriptive curriculum] is a guide...but this [how she enacts curriculum] is how I feel it's best for my kids to do this." As Tami has gained experience over the years, she has felt increasingly comfortable leaving the prepackaged curriculum behind and exercising structurally transformative agency in her instruction.

Sydney noted that in her short two years as an educator, this phenomenon has proven true for her as well. She shared that between her first and second years as a teacher, her views on curriculum changed, because she "[saw] everything laid out." The ability to see the big picture of the curriculum and the standards allowed Sydney to see "where [she could] kind of create these new things, like the independent reading and things like that." Instead of relying on the prepackaged curriculum, she began to see it as a map that she could manipulate to meet her needs and her students' needs.

Hannah has never taught explicitly from a prescriptive curriculum. However, she has transformed her practice over and over again throughout her five years as a teacher. She cited her past teaching experience as one of the main reasons for the continuous transformation of her instruction. When she moved from instruction that was "going over kids' heads" and pushing them to meet grade level proficiency, to instruction that encouraged students to move up at least one grade level in proficiency, Hannah shared that this change was due to "just working and seeing real kids, and also gaining a better understanding of what it means for a student, for a child to be in middle school." Her experience, like that of Tami and Sydney, has allowed her to adjust her practice and to teach in such a way that accords with her beliefs, values, and convictions. 


\subsubsection{Iterational influences: Past teacher education}

For these same three teachers, Tami, Sydney, and Hannah, their teacher education has proven to be a supportive influence mediating their structurally transformative agency.

Tami shared that she "didn't feel like [she]'d wasted any time” in her teacher education. "Like, [with] everything [I learned] in the classroom I saw a specific relevance to how I would implement this," she said. She shared that she felt prepared to design lessons, albeit not very thoroughly, through her bachelor's program, but in her master's program, Tami "was very well prepared to design the lessons," she said. "I felt ready to take charge in a classroom."

Sydney likewise felt that she was "set up to be successful" by her teacher education program. With regard to structurally transformative agency, Sydney noted that she had a coteacher during her student teaching experience who "really just kind of let [her] take the reins and do whatever [she] wanted in the classroom." This taste of freedom to design instruction in the way that she saw fit now marks her career.

Finally, Hannah, more than any other teacher participant, referred to her teacher education program (the Bidwell Teacher Residency) as having had a positive impact on her career. Hannah noted that the thirteen-month program "allowed [her] plenty of opportunity for applying studies directly to a classroom setting, and to get live in-the-moment coaching from a classroom teacher mentor and professors alike." She shared that she was wellprepared by her mentor and her content area professors to design instruction. "I definitely started out better than a lot of other colleagues I know in their first year when it comes to planning. And planning like, rigorous and relevant stuff," she said. From the beginning of her career, Hannah has been a curriculum maker. 
This program impacted Hannah's ability not only to design effective instruction for her own classroom, but it shaped the lens through which she viewed the needs of her school during her participation in the collaborative. Hannah's teacher education program informed her design of the pathways program, which she created because she saw that many other teachers at her school seemed not to have been afforded the same high-quality experience in their teacher education programs as she had in hers. As she planned to kick off the pathways program for teacher professional development in her school, Hannah noted, "I am pulling a lot of stuff that I used for my own, like, personal bootcamp...from Bidwell Teaching Residency." It is clear that this program had a profound impact on the trajectory of Hannah's career, and it is what she points to as the greatest influence on her exercise of structurally transformative agency, which has characterized her practice from the beginning of her career.

\subsubsection{Practical-evaluative influences: Current curricular allowances, expectations, or} mandates

Tami, Kellen, Walt, Sydney, and Hannah indicated that their exercise of structurally transformative agency was owing, at least in part, to the curricular allowances, expectations, or mandates at work in their school or district.

Tami's interview transcript is peppered with talk of the "permission" she felt she was granted by her school, which allowed her the freedom to innovate in her classroom by designing her own course. She believes that the way effective teaching is defined at her school was a part of this feeling of permission. She stated, "[E]ffective teaching here is really 
seen as connecting with the students, getting them involved, to get the results. It's not just getting the results, but what are you doing along the way with those students as humans."

Kellen received permission from the administration to innovate, and even to develop her own course during her participation in the collaborative. Kellen stated in the interview, "I have like one hundred percent autonomy in the class I developed. I can do whatever I want... it's my playground, it's lovely. I can ask kids where they want to go and what they want to do." Not only does Kellen have permission from her school to transform and create the curriculum, but she felt that the changing standards "almost require" innovation, "cause the standards are less about memorizing." When at times she has struggled against the expectations of her colleagues, her freedom to innovate has been backed up by her administrators, who have determined that teachers are to adhere to the standards, but how they teach to the standards should not look the same as the next teacher if it would be ineffective for one's students. In these ways, both Kellen's school's expectations and the changing state mandates have led her to confidently pursue curriculum innovation.

Walt, likewise, has felt only support from his school, the district, and on a greater scale, the state, to be able to innovate without fear of consequences. Without this freedom and support, Walt feels that he would not have been willing to innovate in his classroom. It had a major effect on his ability to exercise structurally transformative agency.

Sydney also felt that her innovation was due, in large part, to the freedom she and the other teachers at her school have to "do whatever [they] feel like is necessary." Sydney found it important that the teachers “didn't have any tests that [they] had to do this year that made it mandatory for us to be at a certain point or anything like that." The lack of mandatory testing has allowed for Sydney to experience greater autonomy in her instructional design. Because of this, she and the other eighth grade teacher did not feel 
bound to the prescribed classroom texts and decided to replace them during the most recent school year.

Hannah noted that the state standards are her guide, and the "types of things that [she has] to be making sure that [she's] meeting." She reiterated continually that her curriculum is that which she has designed to support students' growth in proficiency in reading, writing, speaking, and listening, and that she has permission to innovate as long as she is aligning instruction with the proficiency standards.

\subsubsection{Practical-evaluative influences: Current administration}

Tami, Kellen, Walt, Sydney, and Hannah cited their current administration as one of the major driving forces of their structurally reproductive agency, with several noting that they might not have ever stepped into innovation without this support.

Tami is one such teacher, who, when asked to what influence her growth in innovation was owing, stated during the interview,

Empowerment. Empowerment. Dr. Morley just saying, "Does anyone want to try something different?" Not many principals say that. They're all about results and you know, 'We have to do this this this and this' [uses hand to demonstrate strict goals]. And Dr. Morley's like, “...[W]e're doing these things and still not reaching some of these kids. Who has an idea?" And to have that empowerment for a principal to say, "Go ahead and try it, let's see."

Dr. Morley, Tami’s principal, granted her permission to begin the Sports Literature course that she designed during her participation in the collaborative, and she views his trust in the teachers at her school as crucial to their growth. 'If he hadn't given us that trust, we couldn't have done it," she said. Tami shared that the constant refrain of her principal to the teachers was, 'You all are the professionals. You know, you're in the classrooms, you know what needs to be done...You are the ones coming up with ideas...Please share, please follow 
those ideas, please let me know what I can do to help, what resources you need." Principal support propelled Tami in a powerful way toward becoming an innovative educator. So important to Tami is the influence of administration, that when I asked her what she feels most discourages teachers from continuing their career, she quickly stated, "Lack of support in administration."

When Kellen was asked during the interview which factors played into her ability to confidently innovate in her classroom, she responded, "I think a degree of it really did have to do with knowing that my administrators were okay with it." She also mentioned at Demo Day that she feels as though the opportunity to design a course was given to her by Gwen O'Shea, the facilitator of the collaborative, as well as her principal, Dr. Morley.

Walt, who teaches at the same school as Tami, shared similar sentiments. He believes that the autonomy given to teachers by the staff and administration is "essential" to teachers' flourishing. An assistant principal, Mr. Dunkirk, encouraged Walt to seek out Gwen and help from the collaborative to help with a unit in their Government course. He shared of the administration, "So, I think they were willing to embrace, by and large, deeper learning and the collaborative innovation. And I think that's crucial." Walt went as far as to say that had he not been encouraged by the administration to pursue innovation, he likely would not have pursued it on his own. 'Had Dr. Morley been like, 'We don’t want this [innovation],' [or was] like, 'Make sure butts are in seats, and you know, kids are taking notes' or whatever, I mean, I don't want to get called down to the principal's office," he shared, laughing. The collaborative was founded at Tami, Kellen, and Walt's school due, in large part, to the principal's desire for teachers to be innovators.

In reference to her administration, Sydney used the word 'freedom' several times to describe the support that she and the other teachers receive from them. Like Dr. Morley, 
Sydney shared that her principal also encouraged innovation at their school; in fact, he was the one to sign teachers up for participation in the collaborative. He focused mostly on teachers with fewer years of experience, wanting them to be supported while trying new things in the classroom to reach their diverse student population. "So, he is really encouraging like, the newer teachers to try these new things, 'cause some of the teachers are kind of set in their ways," she said. "So, really, he’s just, from the beginning, he's just [said], 'Whatever you feel like is best, as long as you are, you know, meeting the standards, it's fine." Sydney feels that her administration has played an important role in her becoming an innovative teacher. She noted of their encouragement and positive support, "I don't think it's like that everywhere."

Hannah, likewise, described her administration as "open-minded and positive" and willing to accept and support her ideas for innovation. She shared about the strengths she sees in her principal, saying, “[H]e does put a lot of trust in us. He's not a micromanager... he is very supportive of teachers kind of going out on a limb and trying new things and experimenting and being creative." She noted, "[H]e was the one that signed us all up for the collaborative. With regard to her design for the teacher professional development pathways program, she stated, "I really didn't have to beg him throughout this process. Like, he was very open to me trying out new things for professional development." It is clear that for these innovative teachers, administrative support has been an important ingredient in their exercise of structurally transformative agency. 


\subsubsection{Practical-evaluative influences: Current coworkers}

Tami, Kellen, Walt, Sydney, and Hannah are the five teacher participants who have been shown to express structurally transformative agency in their everyday classroom practice. For all five of these teachers, their coworkers have played a role in this.

Tami, used the word 'critical' several times during the interview to describe various influences on her practice, one such influence being PLCs [Professional Learning Communities]. She shared that in her Senior English PLC, the three teachers involved teach three different courses, but work together to make sure their instruction aligns with the standards and that they are "reaching for the same goals even if [they] have different ways of getting there." She described her PLC as a "good PLC, not a bad PLC," because of the way that they are willing to work together, to listen to each other's ideas, and to share resources with one another, in spite of the fact that their courses are different. Whereas other teacher participants have felt constrained in their practice due to pressure from their colleagues to conform, this has not been the case for Tami. She has received 'permission' to innovate not only from her principal, but from the supportive colleagues surrounding her.

While Kellen has struggled in collaboration with her PLC members at times (as addressed in a later section), she has experienced a relationship with the other Anatomy teacher in her school that is supportive of innovation. She shared that during her first year in the collaborative, she focused mostly on Environmental Science. "[But] halfway through the year [1] applied those same kind of design principles to Anatomy," she said, "because my other teacher is amazing and we both are out-of-the-box thinkers, and I don't know, are okay with being uncomfortable." She noted that because they did not have official PLC time, they met together in the hallway or via text messaging. "But it was always a discussion," she 
said, "rather than 'Here's how you have to teach.' And we were always open to other ideas." Kellen has experienced this relationship as empowering her exercise of structurally transformative agency.

Walt mentioned multiple collaborators during the interview who have helped to support innovation in his practice. He described himself many times as "not the most creative guy," and feels that he has been dependent in some ways on collaboration with others to help him to deviate from prepackaged curriculum and PowerPoint-led, teacher-led instruction. During his first year in the collaborative, he designed his Honors World History class collaboratively with another mentee in the Applewood cohort that year, Gwen Blackwell. When describing the innovative project that he designed as a part of the religion unit, he shared that he came up with it in collaboration with the art teacher, Camden Westcott, who was yet another of the participants during the collaborative's first year. "And without those relationships I don't think I would have been in Camden's room and I wouldn't have seen the puzzle pieces, and if we hadn't been collaborating, we wouldn't have, you know...I don't know what we would've done," he said. Walt also described his PLC as a "very tight-knit group" that works well together, with everyone sharing their instructional approaches with one another without pressure to conform to one another's methods.

Sydney points to the other eight grade Reading teacher as a key influence on her classroom innovation. She and the other teacher have implemented the split classroom model together, which represents one method through which Sydney has expressed structurally transformative agency. Sydney noted, “I don't think I ever would have thought of...the split classroom model if it wasn't for her." She and the other teacher share ideas and learn from one another. "Even though she's been teaching for a lot longer than me, she 
takes my ideas and just, is more than happy to implement them into the classroom and try new things. So, it's very positive," Sydney said.

When I asked Hannah what had caused her to shift her curriculum during the past couple of years, she stated, "I think a big part of it is results. A big part of it also is...the quality and caliber of...colleagues that you get to plan with.” Hannah had not always felt supported by her PLC; in fact, she described her experiences at her first school and at her current school, Whitfield, as "night and day" with regard to collaboration. She shared that her current PLC members share ideas with one another, take turns leading, and challenge one another in helpful ways. She shared that while they are very different and disagree often, their disagreement doesn't feel confrontational or conflicting, but more like a constant discussion. Hannah described her PLC as having a "je ne sais quoi social dynamic," where no one is constantly looked to as the leader or the one who is always wrong. She shared that they view various practices as a menu that they choose from depending on what their goal is at the time. Hannah and her PLC members have exercised a special kind of collective agency that challenges the structures from previous years and moves forward together.

\subsubsection{Practical-evaluative influences: Current students}

For Kellen and Sydney, their students play an important role in their exercise of structurally transformative agency; they have both felt a consistently pressing need to design and modify instruction based on the students that they see in their classroom.

Kellen repeatedly mentioned the particular population of students that she instructs, noting that for them, 'sit and get' instruction is ineffective, whereas she understands that it may be helpful in other contexts. When I asked her why she felt that direct instruction was 
not best for the population of students she teaches, she responded, "Because our population is so diverse. Like, not everybody's a white male or white female, right? Not everybody is, I don't know, quiet... Not everybody has resources at home. Yeah, not everybody can sit in a chair for fifty minutes and do stuff. So, like, a lot of the stuff that I've done, changing the way I teach, is related to that." She referred to a county with a majority white population of students where she had worked previously, saying that the instructional methods that might work there are ineffective at Applewood. "We can come up with all these strategies, but like, that's really all they are," she said. "Until you get into the classroom, then I don't really feel like you know what you're doing."

When Kellen talked about her innovative curriculum, it was clear that her students were at the forefront of her mind in all her design. She has made it a point to design curriculum for the students that she sees in her building, and that her curriculum evolves throughout the year based on what students' interests and desires are. When speaking about her stormwater management unit, Kellen mentioned that she and her students pursued the unit longer than she had planned, because of the students' intense interest in it. "Okay, we're gonna stay in this place 'cause everybody's diggin' it," she reportedly told her students. "You all are applying yourself [sic.], you all are having agency, you all are doing research that is self-directed with real goals that are affecting the community." Likewise, Kellen based a whole project around her class of students with special needs, guiding all of her students to design solutions to the problem of the special needs students' inability to access their outdoor classroom. Student choice, student-led instruction, student engagement and student agency are central to Kellen's teaching.

While Sydney is a less seasoned teacher than Kellen, it is evident that her trajectory regarding student-led instruction is a similar one. She is attentive to her students' diversity, 
their unique needs, their engagement, and their comfortability in the classroom environment, and manipulates her instruction based on the feedback she perceives from them in these areas. When describing her literature choices for her students, which deviate, at times, from the prepackaged curriculum, she attributed her innovation to students' engagement and varying needs, as well as her desire for them to be able to relate with what they read in her class. When Sydney began to introduce Shakespeare's Midsummer Night's Dream over a couple of weeks during her year in the collaborative, she shared, "[M]y kids were looking at me like I was crazy. So [laughs], I went to my co-teacher and I was like, 'Um, we need to just cut this out.' So, we just didn't do it." Sydney's deviation from the prepackaged curriculum was due, in large part, to her sensitivity to her current students.

Sydney has not only changed some of the whole class readings based on student engagement, but she also created a classroom library to "[fit] the needs" of her students with "books that kids can see themselves in and relate to." Sydney noted that she believes, like Kellen, that the population of students with whom she is working is perhaps the greatest determining factor in her curricular decisions, and that this is because she believes that they will be most successful if classroom instruction is designed with them in mind.

\subsubsection{Projective influences: Goals for students}

For all of the teacher participants in this study, their goals for their students, far above their goals for themselves, their school or district, or their curriculum itself, determined their innovative decisions. For Tami, Kellen, Walt, Sydney, and Hannah, these goals have come to shape their everyday practice, while for Robert and Michelle, the effect of the goals for their students mentioned here only reached as far as their innovative designs 
for the collaborative, not yet effecting structurally transformative agency in their everyday instruction. Nonetheless, the structurally transformative agency expressed by all participants, whether short-lived or lasting, was shown to be impacted by the hopes that they have for their students.

Tami shared that the ultimate goal for her innovative unit based on a locally written book is "to engage students in lessons and activities which will encourage them to become independent, inquisitive learners." She spoke much of sparking curiosity and engagement in students, and cultivating critical thinking through her innovative instruction, constantly mentioning students' distant future: “[T] wenty years from now, are they gonna be questioning what's going on in the world around them?” she asked. "Are they going to know if what people are telling them is the truth? Are they going to have the skills to be able to function well?" The answers to these questions are a gauge for the way in which Tami designs instruction for her class. She desires for students' intrinsic desire to learn and their success to extend far beyond her classroom.

Kellen designed her innovative Environmental Science curriculum with her goals for students in mind. The goals propelling her instruction are to interest students in the content, to make them curious to know more, to help them understand the content through experiences, and to grant students opportunities to apply concepts "to their real world existence, so that they can be more educated citizens." Kellen strives to let students "apply their knowledge in a solutions-based manor, rather than demonstrating understanding on traditional multiple-choice tests." She feels strongly that this type of instruction will lead to longer-term intrinsic motivation, critical thinking, and ultimately, success for students.

Walt, like his coworkers Tami and Kellen, concerns himself with students' ability to become critical thinkers_ a sentiment that he reiterated many times during the interview, his 
video diaries, and in the teacher background survey. He wants more for students than to remember names and dates in history class: "I want them to be able to form interesting, coherent, deep questions and look at different pieces of evidence and strains of evidence of what's gone on in the past... and to come up with their own answers," he said. He desires for students to make inferences based on what has happened in the past and to continue to ask questions; these goals have driven Walt's innovative instruction.

Sydney's goals for her students have also been a driving force for her curriculum making practices. In fact, all of Sydney's goals surrounding her instructional plan are goals for students: relationships with students, student engagement, and student voice and choice. She also shared that her goal behind students' independent reading is to foster their love of reading and their enjoyment in the classroom environment. Sydney feels that because she is trying new things in order to "make [her] classroom better for [her] students," she has learned that it is okay to take risks and to fail in the pursuit of innovative curriculum; it is of greater worth to her to try and fail and to learn from failure than to remain safe and to give students curriculum that has different, less personalized goals in mind for them.

In both the design of her everyday classroom practice and the pathways initiative that she created during the collaborative, Hannah has had her goals for students in mind. She shared that her main goals for her students are that they might gain a sense of agency and academic identity, and more literacy-based tools to explore their interests. Giving students the "tools and skills to attain their personal goals and hopes in the world" is Hannah's inspiration for instruction. Hannah's goals for students to have the quality education that they deserve and need, as well as a consistently positive school experience, led her to design the pathways professional development program at her school. While this 
program will help teachers to be more effective, the ultimate end reported by Hannah is that this effectiveness would lead to better outcomes for students.

For Robert, his goals for his students have led mostly to structurally reproductive agency and transmission of the curriculum, rather than curriculum making. However, with regard to his innovative design undertaken during his participation in the collaborative, Robert created his two-week plan for greater technology use and student choice in the classroom with goals for students in mind. Robert believes that "kids really need" technology, and his goal for them to be technologically savvy led him to invest in bringing more Chromebooks into his classroom for students' use during the enactment of his instructional design. Robert believes that especially in science class, students need to be acquainted with scientific discoveries and research that are "cutting edge," and that they also need "access to a person who knows about it and also the technology to get to it." Robert sees himself as this person and designed his project so that his goal for students' technological literacy might be fulfilled.

Michelle, like Robert, is reportedly a curriculum transmitter in her classroom. However, in her design of "Norton Nights," the initiative to garner more parental involvement at her school, Michelle exercised structurally transformative agency, designing "curriculum" for the staffs time together with parents, albeit outside of a normal classroom environment. Michelle's goal in creating this initiative was to involve parents to the end that students become more successful in school, both behaviorally and academically. Michelle outlined some of her guiding questions and ideas for the initiative during the interview: " $[\mathrm{H}]$ ow can we partner with the parents to make sure the kids' needs are being met?...[W] ould it help if we brought in counselors? Or...we thought about having a job fair... different things like that... I think all of that boils down to how we can reach the kids 
to teach them." Michelle's innovation, like that of the other teachers, is intimately tied to her goals for her students.

\subsubsection{The influence of personal and professional identity}

For Kellen alone, among the teacher participants, the supportive influence of her personal and professional identity on her expression of structurally transformative agency was a resounding theme throughout the data. When asked what catalyzed the change in her instruction from curriculum transmission to curriculum making, she responded, "Well, I think it was always in me." Kellen used the phrase 'go rogue' multiple times to describe her tendency to deviate from expected norms regarding curriculum and instruction, and shared that her curriculum making practices exist, in large part, because of her own desires and personality.

When speaking during the interview about curriculum transmitters in her department, she asked the question, “[W] hen I ask you would you actually want to be taught that way [with prepackaged curriculum and direct instruction] [and] you say 'no,' then why are you teaching that way? Or why are you asking for it to be taught that way?" Kellen teaches in the way that she enjoys to teach and reported that her instructional decisions are driven by her needs; however, she feels that her needs are similar to students' needs. She does not use direct instruction regularly because she "just [doesn't] like it," and from her perspective, it is not enjoyable to students. "I value doing things more than direct instruction," she said. "So...I did not use direct instruction very much in designing my class. And it was great." 
Kellen has wrestled with the fact that her instruction differs, in many ways, from the type of instruction that some of her colleagues prefer. She admitted, "I have trouble feeling like I'm going against the grain, but at some point, it broke me, and I couldn't teach like that [using prepackaged curriculum and direct instruction]." Kellen felt that she could no longer adhere to the expectations of her colleagues regarding her instruction because of a deepseated inability to do so, given who she is. "Yeah, I don't fit," she said. "I don't fit in a mold. I don't fit in a box...I don't think I realized that as much until last year when I was able to just create from scratch a course.”

Kellen's innovation, stemming from her personal and professional identity, did not end with the Environmental Science course that she designed during her participation in the collaborative. Kellen shared that her personal and professional identity has been the impetus for curricular change in her Biology course as well as her Anatomy course. She spoke about adding group projects and making learning more 'collectivist' in class because “[she doesn't] like talking"; she applied design principles to Anatomy because she is an "out-of-the-box thinker"; and she shared that she has plans to "go totally rogue and teach all of Biology through the lens of something [she] really enjoy[s], which is ecology.” At every turn, Kellen's curriculum design decisions have been informed by who she is as a person, and from her perspective, this is inescapable. She feels that she must follow her interests and convictions in order to walk authentically as an educator.

Sydney's personal and professional identity, though seldom mentioned, was shown to influence her structurally transformative agency in a positive way. She described herself as "a feedback person" and someone who is "very big on learning and reflecting and implementing new things," and as a funny person who wants to create a classroom environment in which she, herself, would feel safe as a student. Sydney's innovation is 
rooted, in part, in her understanding of herself. She also described herself this way: "I know that I'm not perfect and I know that there's [sic.] ways that I can change things, and I'm always up for that." Sydney's view of herself as an unfinished product aids her willingness to innovate in the classroom.

\subsubsection{The influence of the collaborative}

For all seven of the teacher participants, the influence of their participation in the collaborative had positive effects on the structurally transformative agency they have expressed, whether temporary or enduring. What each of these teachers emphasized in their innovative design, they rooted somehow in their participation in the collaborative, which either magnified their beliefs, values and convictions, helped them to develop new conceptions, or empowered the transformation of their instructional practice in some way, whether in the classroom or in the form of a schoolwide initiative.

\subsubsection{The influence of the collaborative on Tami}

For the teacher participants who were a part of the original collaborative cohort at Applewood High School, Tami, Kellen, and Walt, the change in their instruction, fueled in large part by their experience in the collaborative, has been lasting.

When Tami spoke about the influence of the collaborative on her practice, she used key words like 'community' and 'support,' emphasizing the collective process that took

place. "The collaborative gave me all the resources and the group to talk to, to say, 'How did you do this? What worked for you? What did not work for you?"' she said. "And we would 
go and we would share our success stories and we would share our questions, and so...that aspect of it absolutely was critical in that process." Tami mentioned four times the importance of being able to "bounce ideas off of each other" within the collaborative and shared that she was surprised how much eight teachers from various content areas could help one another with innovation in lesson planning.

As much as Tami enjoys her Senior English PLC, she noted that she doesn't feel like she knows the teachers in her PLC as well as she came to know those in the collaborative cohort. "It really provided that chance for us to like, become friends? As we were working? And I think that just takes your work to a different level," she said. Tami spoke more than once about being able to take her work "to a completely different level," and the two greatest influences that she noted were the support of her principal, and her participation in the collaborative. The influence of the collaborative on Tami's practice has extended beyond even her classroom, to larger spheres of influence: other teachers in the district and English teachers nationwide. Tami believes that she is presenting at conferences now, like the National Council of Teachers of English conference, because the collaborative, and Gwen in particular, empowered her to believe that she had something to share and introduced opportunities for her to do so. "I mean Gwen would just straight up say, 'No, you all need to be sharing these ideas," she said. "So, she really encouraged us to look for opportunities to present." Because of her experience in the collaborative, Tami's perspective on leading professional development has changed. "I used to get nervous...talking in front of other people, and now I'm like, 'Oh my gosh, let me share this with you!'” she said. Likewise, Tami is surprised by the fact that she is now mentoring other teachers, some of whom have been Sydney and Robert. She has been compelled to pass on what she feels she was richly given through her collaborative experience. 


\subsubsection{The influence of the collaborative on Kellen}

Kellen claimed that "the collaborative impacted [her] design heavily." She sees the collaborative as a means by which she received 'permission' to innovate, which she shared several times. "I think part of it was, I needed permission to change the way I taught," she said as she elaborated on the influence of the collaborative on her instruction. During her year in the collaborative, Kellen was designing her Environmental Science course. She said that going into the year, she knew she wanted to create it from scratch, and that she did not like 'sit and get' instruction, but that she needed "permission from somebody else" to do things differently than she had in the past. At Demo Day, Kellen shared publicly that she felt that her teaching had changed greatly, and that the change in large part could be credited to her principal, Dr. Morley, and Gwen O’Shea, the facilitator of the collaborative.

At the same time as she feels that participation in the collaborative has changed the shape of her instruction, Kellen also expressed several times that she believes the collaborative served merely to accelerate change in her instruction that would have happened either way. During the interview, Kellen shared, “[I]t's very clear even just reflecting out loud that I probably would've gotten there at some point on my own. Maybe not as quickly as last year."

One of the collaborative activities that evidently served to accelerate the change in her instruction was the student shadowing experience. Kellen noted that she was 'surprised' at how great an impact reflecting on students' experience in school had on her. She already knew that she did not enjoy lecture, but when given the opportunity to follow one of her students to all of her classes throughout the day, she "saw that [the student's] classes were often filled with minimally engaging lectures and note taking, with little student input or 
movement." After seeing this, Kellen's previously-held curricular conceptions were solidified, and she wrote about them in her 2018 Conservation Teacher of the Year application: " [] t became clear to me that I must be diligent when cultivating my class culture, aware of student interests, and ensure I presented content in a way that was relevant to the lives of students," she wrote.

During her time in the collaborative, Kellen "re-envision[ed] what [she] thought curriculum development should be," and her instruction of Environmental Science came to involve more project-based learning, with more group work and very little direct instruction. Her experience in the collaborative caused her to question her practices in other courses as well, such as Human Anatomy. Kellen reflected, “[A]fter doing some...human-centered design thinking stuff with Environmental Science, I was like, 'Why am I doing that? Why are we having students remember these [terms] like, 'simple squamous epithelium'? They don't need to know that. Like, they're not doctors!' Kellen's innovative practice began with her Environmental Science course, but heavily impacted by the collaborative, it has come to extend to all of the courses that she teaches, and even to the classrooms of others whom she now mentors.

\subsubsection{The influence of the collaborative on Walt}

Walt was not sure what he originally expected to gain from being a part of the collaborative, but looking back, he noted, "I think it helped a lot in terms of my teaching practices and making my lessons more student-centric...taking me out of, sort of, the central role as a teacher...making me more of a facilitator." Walt was impacted by the inquiry-based, deeper learning focus of the collaborative, which he feels "pushed [him and the other 
teachers] to develop more skill sets within the content," instead of focusing merely on content knowledge. Walt described the impact of the collaborative as 'lasting' and shared, "[]t sort of shifted my whole pedagogical practices [sic.] within the classroom."

Of all of the aspects of yearlong participation in the collaborative that could have influenced Walt, it is evident that his collaboration with Gwen O'Shea was the most impactful to his practice. By the encouragement of his assistant principal, Walt sought out Gwen to see if she could help with a particular unit in his Government class. They ended up designing a whole unit and teaching it together. Walt shared that this experience "showed [him] where things were going" in his classroom, and "opened [his] eyes to being more open, vulnerable, innovative." Walt shared at Demo Day that now, as a mentor, he is "trying to take what she did for [him] and kind of open some other teachers' eyes also.”

Walt is sure that without having been a part of the collaborative, his instruction would still look the same way it did before that year. "I would not have had a plan, had it not been for the collaborative," he said. "I would've been doing the same things over and over again that I've always done... with kids doing book work and me delivering PowerPoints. Not because I'm lazy, but just because it's what I did, right? I mean, I thought I was doing a good job."

For Walt and the other two Applewood teachers in this study, Tami and Kellen, the impact of the collaborative was profound and lasting. In my interview with Gwen, the facilitator of the collaborative, she noted that in some ways, the effects of the collaborative on these teachers surprised even her. She shared:

You know, a lot of the teachers, like, Kellen went on to apply for a bunch of like, teaching awards and like, Tami started presenting at PDs...Walt became the department chair. Like, they all got this like, taste in their mouths for leadership? That...wasn't the thing that I like, advertised, but it was really empowering for a lot of them, I think. And so, they became mentors. 
The positive influence of the collaborative on these teacher participants' innovation and structurally transformative agency did not stop at their own practice; it continues, in a ripple effect, to impact other teachers.

\subsubsection{The influence of the collaborative on Sydney}

The influence of the collaborative on Sydney's exercise of structurally transformative agency was great. She emphasized that the encouragement, support, accountability, and feedback that the collaborative provided to her were invaluable. "J]ust from the start of the collaborative until now, it really just transformed the whole way that I go into teaching," she said. "And it transformed the way that I... want to see my classroom." She feels that it was the collaborative that allowed her to begin to see the prepackaged curriculum as an outline instead of a mandate.

Sydney shared that the monthly meetings were the aspect of the collaborative that she believes to have been the most impactful. Sydney described herself as a "very big feedback person," so she especially valued the variety of perspectives and ideas that she and the members of her cohort were able to share. Moreover, Sydney felt that the members of her Cromwell cohort were encouraging and positive, which fed her desire to give her best effort and to stay the course in her innovative endeavors. " $[1] \mathrm{t}$ is a lot of work to change those things and make sure you're doing those things that need to be done in the classroom instead of just using the same worksheets every year," she said. She feels that the collaborative gave her the "positive support system" that she needed.

Sydney credited the collaborative as the influence that caused her to see the need to design instruction that meets students' needs; it also taught her how to reflect on her 
instruction, and that it is okay to fail. Sydney was given courage to try new things by her participation in the collaborative.

\subsubsection{The influence of the collaborative on Hannah}

While Hannah stated that her participation in the collaborative did not change the way that she views education, nor did it change her classroom instruction, she shared that her experience "was a very positive one" that led her to develop a new curricular focus on teacher professional development.

The most powerful aspect of the collaborative for Hannah was shadowing a student for a day, which she shared in one of the video diaries, the interview, and at Demo Day. She feels that through this she gained a better understanding of her school through the lens of a student, and the realization that the students have a very inconsistent school experience, from student to student and from year to year. She found that out of seven classes, she found five to be engaging, relevant or interesting, and two to be less than compelling; one of the two, taught by a veteran teacher, was very unstructured, while the other, taught by a novice teacher, had a very negative feel to Hannah, based on student-teacher interactions. "So that got me thinking about... what a powerful role that each individual teacher has in their room," she shared in the interview, "and thinking about how to support teachers in developing their practice in general."

Hannah emphasized that her experience in the collaborative reinforced the importance and notion and everything that teachers and staff want for their students regarding effective instruction needs to be modeled for faculty in professional development. 
Hannah realized that teachers are still students, and that best practices should be taken up in instruction regardless of the age or experiences of students.

"I do think that it was a very empowering experience," Hannah shared about the collaborative, "because as a...second year teacher in the building, as a fifth year teacher in terms of years of instruction I've been doing...this project did give me confidence to advocate for a bigger change." In spite of her being viewed as a novice by some, Hannah was encouraged by her participation in the collaborative to extend her influence beyond the four walls of her classroom to consider how she could better students' experience in her school as a whole.

\subsubsection{The influence of the collaborative on Robert}

Robert, as well as Michelle, had mixed feelings about the collaborative and its influence on their conceptions and practices. However, because some of the influence that they noted was positive, and that positive influence was tied to the structurally

transformative agency that they expressed through the enactment of their innovative designs, their experiences are included in this section.

When Robert was first introduced to the idea of joining the collaborative, he was distrustful, not knowing much about it. He shared his initial impression in the interview: "[]t seemed to me to be something more focused on data collection, which I was skeptical about, because I know a little bit about research. And you know, I was worried about the informed consent and you know, if somebody was really trying to profit off of...you know, trying to data mine for innovation ideas and, you know, so on." 
In spite of his reservations, Robert felt that he was 'volun-told' to be in the collaborative. During data collection, Robert emphasized that in the collaborative, his ideas about curriculum did not change. He even noted several ways in which he felt that the collaborative had had a negative impact on his work life at Cromwell. Robert shared that his department chair did not understand what he was doing in the collaborative, and that he was “always having to answer for why it wasn't 'equitable' that [he was] doing certain things.” In other words, Robert's innovative instructional plans rubbed his department chair the wrong way, to the point that they were deemed 'inequitable.' This bothered Robert. Moreover, Robert mentioned the 'exposure' that he opened himself up to by allowing for more flexibility in his classroom, noting that this "led to a lot of problems." He stated, "And I really didn't want to do it." At this point during the interview, Robert revealed that he had felt obligated to make some of the structurally transformative changes that he designed during the year. He noted the pressure that he felt from his principal, whom he described as "like everyone else in public education" who wants teachers to invest in research-based best practices without having a full understanding of the 'consequences' that might come with this endeavor, especially when working with certain populations of students. Some of the progressive practices that Robert felt pressured toward, and scoffed at, were those of project-based learning and flexible seating.

In spite of the negative sentiments expressed in this part of the interview (in the time just after a difficult phone conversation with a parent), Robert's tune changed greatly in the video diaries. Here, he noted that through the collaborative experience, his "role in the curriculum definitely changed," at least during the enactment of his instructional design. "I was really grateful to see how some of the higher up...folks...the leaders, both in WCPS and my school, were both supportive...toward having innovative teachers," he said. He 
reiterated that he did not change the curriculum itself, but merely his role in it, as he allowed students to utilize more technology and to experience more choice and control in his classroom. He noted that he was helped with this undertaking by the other innovative teachers in his cohort, as well as the mentors like Tami, whom he feels offered "a lot of support."

Although Robert claimed that his curriculum only looked different than usual during the final two weeks, when he implemented his innovative design, he shared that he has plans to continue to innovate. "You know, I'm going to...not just... be so solidly focused on one plan," he said. He shared that by practicing differentiation to "widely different levels" during the enactment of his instructional design, he was encouraged to continue to differentiate.

Robert believes that without the collaborative experience, he would never have pushed himself to "open up" his curriculum, out of fear. "You know, I...think I was afraid that, you know, if I gave away my control, that... my classroom would be mismanaged...more than what I would be comfortable letting my colleagues and leaders in my school think that I was capable of doing," he said in a video diary. He continued:

And you know, it's weird, because in some ways, you know, I think they [the administration] actually wanted to see that. They wanted to see, you know, the kids...participating in controlled chaos. And sometimes it was controlled and sometimes it wasn't, you know? I'm still not sure what their perception was. You know, at the end of the day, you know, I do feel like there was some negative that came from it. But, you know, like I said, there were a few students that really got something great from it, so, from that point it was good.

The ways that Robert saw his participation in the collaborative as negative pertained to a sense of a loss of control—of a well-managed classroom, of being well-thought-of by his colleagues and leaders, and of his strong and safe grasp of structurally reproductive agency. On the other hand, the areas in which Robert saw positive change from the experience were 
related to a growing ability to innovate and to exercise structurally transformative agency in the classroom.

\subsubsection{The influence of the collaborative on Michelle}

As for Michelle, the impact of the collaborative from her perspective was minimal, but the influence that it had was related to her expression of structurally transformative agency through the design and enactment of Norton Nights. Michelle shared adamantly in both a video diary and the interview that being a part of the collaborative had not changed her curricular conceptions or practices, and she emphasized in the interview and even at Demo Day that she had expected to be a mentor in the collaborative, and not a mentee, given her seventeen years' experience. Although it seems Michelle has a bad taste in her mouth for the collaborative in a couple of ways, she still described the collaborative experience as 'eye-opening' at Demo Day, and claimed that it had helped her and her colleagues to have "a broader understanding of everything [they] needed to do to contact parents" for Norton Nights. In some small way, the collaborative seems to have encouraged Michelle's exercise of structurally transformative agency through Norton Nights, even though innovation is still not characteristic of her everyday instruction, and she does not plan for it to be. 


\subsection{INFLUENCES THAT THREATENED TO CONSTRAIN TEACHERS' STRUCTURALLY TRANSFORMATIVE AGENCY, BUT DID NOT}

It is important to note the influences on teacher participants that threatened to constrain their structurally transformative agency, but did not succeed in doing so. For various participants, negative situations regarding past teaching experience, past teacher education, current curricular allowances, expectations, or mandates, current coworkers, current students, and the influence of personal and professional identity could very well have served as excuses for them to remain in a state of non-agency or to express structurally reproductive agency; instead, many of these difficult situations or experiences merely led them to see a greater need to innovate. Table 25 highlights the influences that functioned in this way for the teacher participants.

Table 25. Influences that Threatened to Constrain Teacher Participants' Structurally Transformative Agency, But Did Not

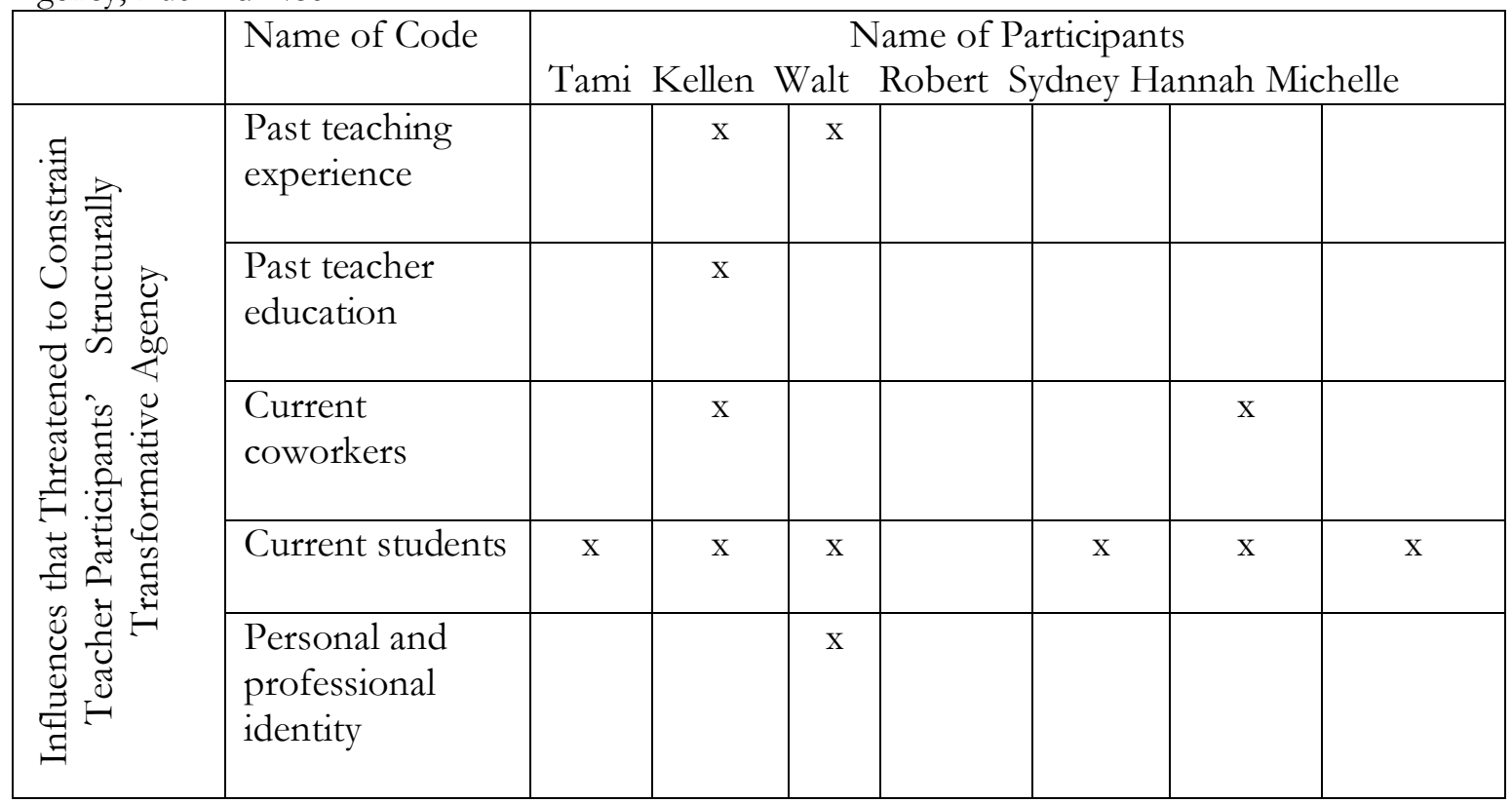




\subsubsection{Iterational influences: Past teaching experience}

As previously stated, Kellen's teaching experience, for many years, consisted of teaching prepackaged curriculum via direct instruction in a large state university setting.

Later, when she became a secondary teacher, she noted that she had experienced pressure to conform to her coworkers' style of teaching, which again, consisted of direct instruction. Not only this, but she experienced difficulty with student behavior for the first time. These types of situations, which tempt many (including some of the teacher participants in this study) to continue to teach using prepackaged curriculum in as direct a method as possible, for fear of losing esteem with colleagues or losing control in the classroom, did not stop Kellen from endeavoring to innovate. She noted that in year two of teaching in secondary education, she "started to experiment with projects because [she realized that [she] was not happy talking all the time," and she realized that the instruction that worked for some students would not be effective for all. She overcame the pressures of her past teaching experience to become an innovative educator.

Likewise, Walt's past teaching experience, which he describes as involving direct instruction, PowerPoints, note taking, and book work, could have set the tone for his career. He noted that he was comfortable in this teaching style, and that if it had not been for the collaborative, he likely would have remained in it. Nonetheless, the comfort of 'sit and get' instruction was not enough to hold Walt in his structurally reproductive habits.

For both Kellen and Walt, their negative past teaching experiences now serve to fan the flame of their classroom innovation, as they remember from where they have come, and do not desire to return there. 


\subsubsection{Iterational influences: Past teacher education}

Kellen describes her teacher education program as lacking in rigor, and comparable to an Associate Degree next to the hard-won master's in Zoology that she had received. She noted that she felt like she was only was doing the Master of Arts in Teaching because she "had to check off a box," and that she did not feel any better prepared to teach than she did before pursuing the degree.

In retrospect, Kellen wishes that she had done a "true internship" like the one that Hannah had experienced. She shared that she had thought, going into secondary education as a teacher, that she knew how to teach because she knew the content. However, she experienced a rude awakening when her career began, and claimed that most of what she learned, she learned on the job out of necessity. In spite of Kellen's difficult start and lack of quality preparation, from her perspective, she has been able to experience success as a teacher and exercise structurally transformative agency.

\subsubsection{Practical-evaluative influences: Current coworkers}

For both Kellen and Hannah, some current coworkers have served to accelerate their exercise of structurally transformative agency, while others have presented challenges to their innovation.

Kellen described herself as having "an okay working relationship" with the Biology PLC at Applewood, sharing that there have been some struggles regarding their differences in teaching methods. "And push-back," she said, "because they don't teach like I teach.” She

noted that her innovative ideas have been met with resistance at times, reflecting that maybe 
those PLC members feel that implementation of the ideas would take too much time, or that they would not know how to implement them, so they would rather not entertain them. "I'm not sure why," she said. "I feel like as teachers, many of us are like, institutionalized." Kellen has been unwilling to conform to the way that the rest of the Biology PLC members teach. "I just couldn't do it," she said. Speaking of the Biology department chair, Kellen noted, “It's difficult, 'cause I was like, 'Dude this is great!' [regarding her innovative ideas] And he's like, 'I don't want to do that.' And then, well, I feel like I can't do it, but then I did it anyway." Thankfully, she feels that the Biology PLC has moved toward an understanding that they do not all have to teach the same way, as long as they are pursuing the teaching of the standards. Even if not for this progress, though, Kellen would still have pursued innovation, valuing agentive instruction above a seamless working relationship with her colleagues.

The influence of Hannah's coworkers has been, for the most part, positive; however, she mentioned some dynamics that could potentially have served as stumbling blocks to the implementation of her pathways program. She shared the difficulty of trying to reach colleagues who have such a wide range of teaching experiences, and that many of the teachers in her building are pushing themselves to be better, while many are not. Hannah also noted that her school has a very positive culture, but simultaneously a "very gossipy culture." This is fueled in part by the fact that teachers who are putting forth a lot of effort are often rewarded by the administration and given "more liberties and freedom." These teachers are talked about by others, who feel that their treatment is unfair. This "gossipy culture," especially with Hannah being a less seasoned teacher who certainly puts forth a lot of effort and has chosen to spearhead a schoolwide initiative, could potentially have deterred 
Hannah from pursuing the pathways program. Instead, Hannah has chosen to continue her project, believing that the benefits will outweigh the risks involved.

\subsubsection{Practical-evaluative influences: Current students}

Having students who have historically been classified as 'low-performing,' or deemed 'disengaged' or 'poorly behaved,' who come from a lower socioeconomic class or a 'bad' neighborhood, or who simply do not like change, are factors that regularly tempt teachers to continue teaching the prepackaged curriculum. For some, it seems too dangerous to try something new and to risk students having an extra moment to misbehave or criticize the lesson. It is too dangerous to spend so much time creating something that may not be effective. For Tami, Kellen, Walt, Sydney, and Hannah, these temptations are surely present, but they have not given into them; rather, they continue innovating and transforming the curriculum in the ways that they feel are best for students' learning, regardless of what could go wrong. While Michelle's everyday practice does not yet include innovation, she also rose above these possible temptations with her innovative design to exercise structurally transformative agency through her Norton Nights initiative.

Tami noted in the teacher background survey that her class was "designed specifically for students who either have not benchmarked on the ACT or who have a history of being disengaged in the learning process." She continued, saying that her curriculum is "designed to allow for more student ownership (agency) in the learning process." Instead of transmitting the prepackaged curriculum to these students whom she easily could have assumed would be disengaged no matter what she did, Tami chose to 
innovate, believing that these students could be engaged learners who took ownership of their education.

Kellen readily acknowledged the reality of the student population that she teaches, and that they need different instruction than students who are white, quiet, and have resources at home. Instead of maintaining stricter control of her classroom and utilizing more direct instruction, which one might do who fears losing control, Kellen offered students more choice, and more opportunities for outdoor exploration, movement, collaboration, and field trips.

Walt shared that since shifting his pedagogical approach to include more critical thinking and inquiry-based learning, he has received push-back from some students, who struggle with the ambiguity of questions that do not have a black-and-white answer. "I had one girl really freaking out," he shared. "She was like, 'This isn't even a real question!' Like [she was] really beaten up about it." He shared that many students have been uncomfortable with the gray area for which his questions and projects allow, and are constantly asking, "Is this the right answer?" Though it would be easier to do what is comfortable for students, Walt believes that critical thinking is a necessary skill, and he continues to foster it in students through means that are sometimes difficult for them.

Sydney shared that a lot of the students at Cromwell come from backgrounds in which they are not safe at home, or they have insecurities that they deal with at home, or their parents are minimally involved in their education. She noted that the norm for these students at school is to be yelled at and to feel as though their teachers do not care about them; many teachers may reason that this is due to their apathy and poor behavior. Sydney, however, makes a point to create her curriculum and classroom environment in such a way 
that shows her students that she cares about their needs and interests, and seeks to be "that caring adult in the classroom for them."

Hannah shared that most of her students are struggling readers, many of whom read on a second-grade level when they are actually in sixth or eighth grade. Nonetheless, Hannah did not mention this as a factor that keeps her from innovating. On the contrary, her instruction is constantly transforming as she seeks to best meet her students' needs.

Finally, Michelle works with many students whose basic needs, from her perspective, are not being met, and who struggle to see possibility beyond their own neighborhoods. Whereas it could be tempting to believe that these students' parents do not and will not care about their education, Michelle geared her innovative design toward reaching the parents of those students in the two neighborhoods with the lowest socioeconomic status. The potential difficulties of targeting this population of parents and their students did not deter Michelle from innovating to reach them.

\subsubsection{The influence of personal and professional identity}

Walt's personal and professional identity could potentially have had negative effects on his exercise of structurally transformative agency, had he let it. Walt described himself as "not a curriculum expert" and "not the most creative guy" more than a couple of times during the interview. He sees his lack of creativity as a potential stumbling block to innovation, but it became apparent in the data that Walt's view of himself as non-creative is precisely one of the influences that led him to seek help from Gwen, from participation in the collaborative, and from other colleagues. His negative view of his own ability to create 
led him to foster meaningful relationships with people who could support him and help to foster classroom innovation alongside of him.

\subsection{INFLUENCES THAT CONSTRAINED TEACHERS' STRUCTURALLY}

\section{TRANSFORMATIVE AGENCY}

Table 26 highlights the influences reported by the teacher participants that most constrained their structurally transformative agency. While Tami, Kellen, Walt, Sydney, and Hannah have experienced influences that they have viewed as negative at various times, these influences have not been detrimental to their ability to exercise structurally transformative agency and to practice innovation in their everyday classroom instruction. Robert and Michelle, on the other hand, reported several influences that keep them from innovating and achieving structurally transformative agency in their everyday classroom practice. These influences are described below.

Table 26. Influences that Constrained Teacher Participants' Structurally Transformative Agency

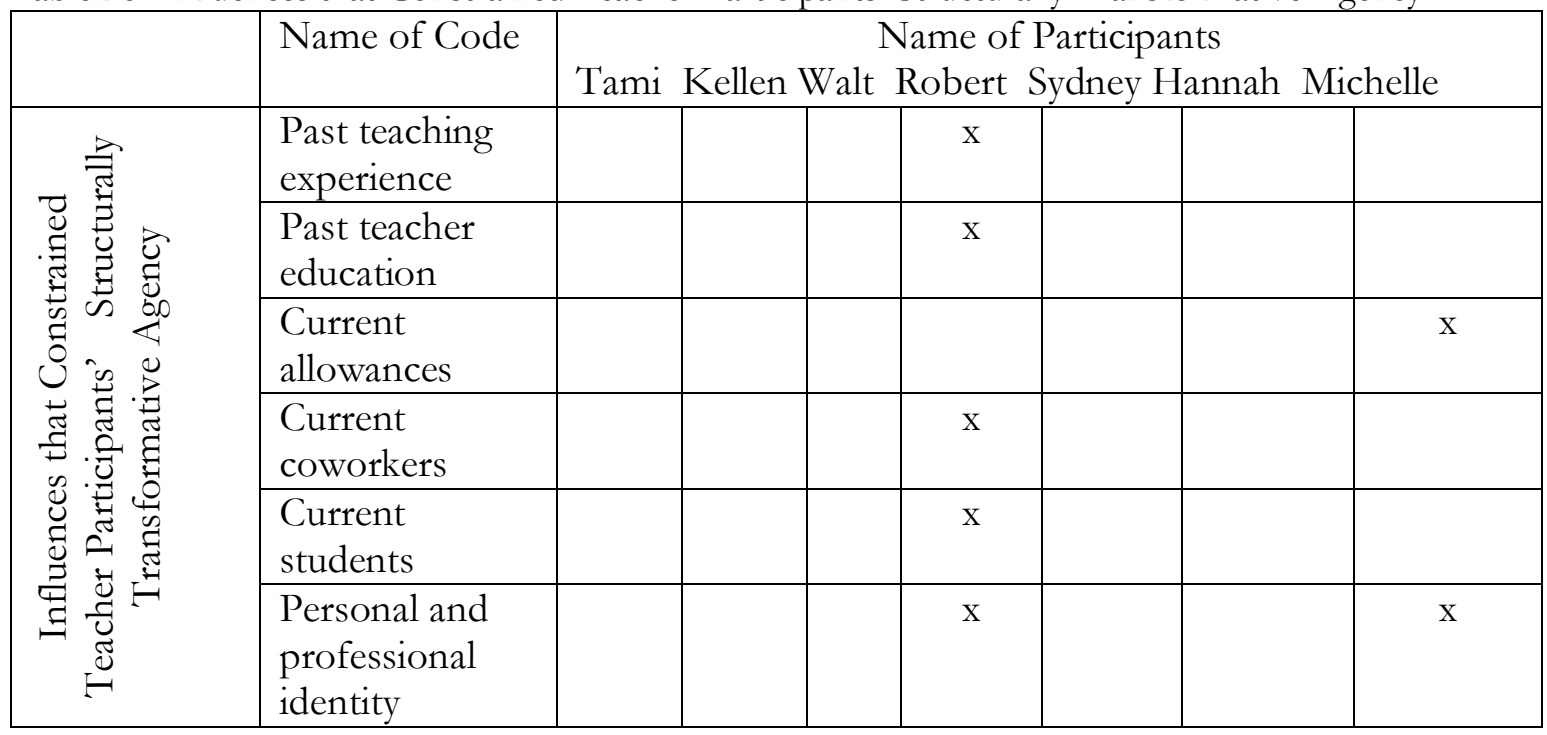




\subsubsection{Iterational influences: Past teaching experience}

Robert's past teaching experience has come to bear in a negative way on his current ability to exercise structurally transformative agency. Robert's past experience with specific science content areas is one aspect that has reportedly caused him to hesitate to take on new content when it is assigned to him, especially in an innovative way; but the main aspect of his past teaching experience that negatively impacts classroom innovation for Robert is the setting in which he taught. Robert described the students that he taught in Germany as from “a different segment of society;" this 'segment' was one of affluence, and students were given a lot of freedom in the school where he worked. Robert contrasted his experience as a teacher at Cromwell with this one, explaining why he was hesitant to carry out an innovative design through the collaborative:

Okay, so, I'm now working at a school...that is one of the bottom-achieving schools. And I'm working with a population of people that I have not in the past. I mean, seventy-four percent of our kids are getting free and reduced lunch, so there's demographic stuff there that, you know, really puts me in a place of working with disadvantaged people. And, you know, I haven't done that a lot before now. Before now, I've been a teacher in private schools, you know, international schools, living out of the country. And so, I was a little bit hesitant to design something like this for students that I knew had a lot of apathy, that probably would, or I could foresee, not using the time properly. And I wasn't totally incorrect in that.

Robert carried out his instructional design contrary to his convictions about his current students' abilities, but innovation has not yet characterized his normal classroom practice. This is due, in part, to his past teaching experience with students whom he views as drastically different than his current students. 


\subsubsection{Iterational influences: Past teacher education}

When Robert was asked about his teacher education program, he shared, "I didn't really have a teacher education program." Rather, he was accepted as a teacher in Washington County Public Schools on the basis of his military background and the passing of Praxis exams. Robert feels as though the way that he views curriculum was heavily impacted by the doctoral degree he received in education, but at the same time, he admitted that he "did not feel prepared to be a teacher." Robert compared himself to his wife, who is also a teacher, and noted that he feels she has been better equipped to create games and to "inject more fun" into learning. "I think the thing I found myself most deficient on [sic.] was

specific methods," he shared. Admitting that he still struggles to know which methods might be effective in the classroom, Robert shared that he feels he could be a better teacher if he had had one or two classes in this area. Robert points to his lack of teacher education as one of the main causes of the absence of regular innovation in his instruction.

\subsubsection{Practical-evaluative influences: Current curricular allowances, expectations, or} mandates

Michelle readily admitted that she had not created a lesson plan for several years, as she utilizes the prepackaged curriculum provided by WCPS for science. While she disapproves of this curriculum and feels as though there is "no student engagement" in it and that reading from a script feels fake to her, she shared that when deciding what to pursue regarding her innovative design, she looked at the curriculum and decided that it was 
a lost cause: "there's nothing I felt I could do for that," she said. Hence, she decided to pursue Norton Nights instead.

A large part of Michelle's feelings of helplessness regarding classroom innovation has to do with her perception of the curricular allowances, expectations, and mandates set out by the district. Michelle feels bound to follow the content curriculum that the state mandates, because, "let's be honest, we live and die by the test here," she said. She continued, "So why wouldn't you follow what curriculum [the Department of Education] said? Because you know that's what we're ultimately going to be judged on."

In spite of this first barrier to innovation, Michelle's greater obstacle, she feels, is the allotment of resources that the district provides. She explained that only at the times when various units are to be taking place in accordance with the prepackaged district curriculum can teachers receive materials to assist them with those units. The district sends teachers tubs with "the materials you need to do the labs and stuff like that," she said. "But we only get them for a small amount of time... while we're doing the unit. Then, they have to go back." Michelle believes that even if she wanted to innovate, she would be unable to do so because of the strict timing regarding the availability of resources.

Interestingly, when Michelle was asked what would have happened had she desired to design an innovation instructional plan for the collaborative to enact in her classroom, she shared that both her principal and her assistant principal had been supportive of this possibility. Michelle explained that her principal had encouraged her to pursue innovation in a unit that she described as a "snore fest" that causes her to get bored teaching. Michelle even acknowledged that her principal would have found a way to help her to have the resources to innovate; yet she did not choose to do so. Likewise, Michelle recounted a conversation she had with her assistant principal: 
And so, you know, that's like, and I've talked about it, I'm like, 'God. I wish we could do something different.' And my AP said, 'Well, do what you... you know, change the curriculum. Do what you want to do.' Which, I know that option is there. But it's still hard because... we don't have the supplies in house.

In spite of school leaders who encourage her innovation and vow to find a way for Michelle to have the resources she needs, Michelle still sees the curricular allowances and expectations, especially regarding resources, as "the biggest barrier" to innovation.

\subsubsection{Practical-evaluative influences: Current coworkers}

On one hand, Robert's current coworkers serve as a source of encouragement to him. He described himself as being close to his team members, and even shared that at some points during his career at Cromwell, "[his] team members have been the only reason [he] got up and came back to school.” From his perspective, the teachers at his school also "work harder than any people [he's] ever seen."

On the other hand, it is apparent that Robert views his coworkers' preferences and opinions as one of the reasons he does not choose to innovate regularly in his classroom. He shared during the interview that his department chair did not understand what he was doing through the collaborative, and that he constantly had to "answer for why it wasn't 'equitable' that [he was] doing certain things" through the program.

Robert also stated that he feels as though he is given the prepackaged curriculum in order to use it, and to those who stray from it, "the people who are wanting to go by the book are more like, 'Well, who are you trying to be now, hotdog? Why are you doing more or changing it? Why are you putting more thought into it?"' Robert made it clear that this criticism would not come from all of his coworkers, but that it would be enough of them "to pick up on the griping of it." He feels that some of his coworkers question why anyone 
would use anything besides the prepackaged curriculum "when [their] life could be really easy, and [they] wouldn't have to plan anything else." He feels that "people want the ability to just coast, they want the ability to just open the book and teach from it." The pressure that Robert has felt from his non-innovative coworkers is definitely taken into account when he considers innovation and has played a part in keeping him from regularly innovating.

\subsubsection{Practical-evaluative influences: Current students}

It is evident that the way Robert views his students plays a large role in what he is and is not willing to do in his classroom. At Cromwell, Robert feels that he deals with many behavior problems and that students are generally uninterested in learning. "[T]he students are not very focused on achievement, and...engagement is an issue, and so is apathy," he said. He described his school as a place where "a kid could bring a weapon... and put it in a locker and pull it out when they go for a bathroom break and come back and kill us." He shared that his students, from his perspective, seem to have a "pride of, 'How messed up can we be, and still be okay?"' Robert feels that they deliberately push back against authority of all kinds and conformity to the standards for school conduct set before them.

As a consequence of how students are viewed at his school by Robert and others, Robert noted that students there do not have "nearly the amount of freedom that many schools give their students," and that there would be problems if they did. Students are walked from one place to another in a line. Robert shared that because of students' apathy and behavioral problems, he is constantly asking himself, "If I give this assignment, what's the overall result going to be?" Oftentimes, Robert decides against projects, because class is only forty-five minutes long and "none of them take it seriously anyway." He feels many 
progressive methods could not possibly be effective at his school because of the students who go there.

Robert chose to innovate for his instructional design during his participation in the collaborative, in spite of his reservations. He stated, 'I wasn't sure how they were going to respond," when speaking about his instructional design, the enactment of which he viewed as a great risk at his bottom-performing, high needs school. "I was a little bit hesitant to design something like this for students that I knew had a lot of apathy, that probably would, or I could foresee, not using [sic.] the time properly. And I wasn't totally correct in that," he said. While the carrying out of two weeks of innovative instruction had some positive results, Robert felt that his push for more student choice and autonomy also had some negative consequences, due to students' misbehavior and the chaos that he perceived as ensuing when he loosened his reins on his classroom instruction.

Robert does not choose to innovate regularly in his classroom. He shared that he "usually would condemn that [teachers not innovating], but considering the mental strain that [teachers at Cromwell] are under with so much...drama... with the environment being as difficult as it is," it makes sense to him to use the prepackaged curriculum.

\subsubsection{Projective influences}

There were no projective influences that kept teachers from achieving structurally transformative agency. 


\subsubsection{The influence of personal and professional identity}

Interestingly, both Robert and Michelle, the teacher participants who do not regularly express structurally transformative agency in their classroom instruction, were the only two participants in this study who saw themselves as curriculum experts of sorts. Robert noted, "I suppose I would be considered an expert in [curriculum]," due to his doctoral degree in education. He noted, in fact, that his "dare to be great moment" would be to become an academic researcher, a career that would allow him to focus on curriculum theory full time.

In a similar vein, Michelle thought to herself before the collaborative year, "You know...this is year seventeen. I think I have some knowledge to impart." She thought that she was going to be a mentor in the collaborative, instead of a mentee, given her many years of experience. “I don't need to be a mentee. Who are you kiddin'?” was her initial reaction upon finding out that she would be mentored through the program.

Both of these teachers feel as though their ideas about curriculum and their roles in the curriculum have remained the same for many years (save for Robert's two weeks of implementing his instructional design), and they are confident in them. Their contentment in their habitual beliefs and practices keeps them from pursuing innovation in the classroom, and from achieving structurally transformative agency; rather, their firm beliefs cause them to continue to reproduce the curriculum that is given to them and the classroom practices that they are used to carrying out. 


\subsubsection{The influence of the collaborative}

Although both Robert and Michelle did not feel that their experience in the collaborative was entirely positive, it is clear from the data that participation in the collaborative did not keep any of the participants from achieving structurally transformative agency, but rather, encouraged it, even in Robert and Michelle. The influence of the collaborative did not impede teachers' ability to innovate.

\subsection{INFLUENCES THAT COULD HAVE SUPPORTED TEACHERS' STRUCTURALLY TRANSFORMATIVE AGENCY, BUT DID NOT}

The teacher participants experienced ecological influences that increased their structurally transformative agency and decreased their structurally transformative agency, as well as influences that could have decreased their structurally transformative agency but propelled it instead. Finally, in this section, I underline the influences experienced by the teachers in this study that could have functioned to increase their structurally transformative agency but were ineffective to do so or seemingly insignificant according to the teachers' reports. Interestingly, all of the influences mentioned in this section effectively increased some teachers' structurally transformative agency, while they were ineffective for others. 
Table 27. Influences that Could Have Supported Teacher Participants' Structurally Transformative Agency, But Did Not

\begin{tabular}{|c|c|c|c|c|c|c|c|c|}
\hline & Name of Code & \multicolumn{7}{|c|}{ Name of Participant } \\
\hline \multirow{6}{*}{ 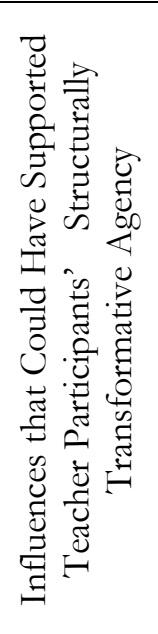 } & $\begin{array}{l}\text { Past teaching } \\
\text { experience }\end{array}$ & & & & & & & \begin{tabular}{l|l} 
& $\mathrm{x}$
\end{tabular} \\
\hline & $\begin{array}{l}\text { Past teacher } \\
\text { education }\end{array}$ & & & $\mathrm{x}$ & & & & $\mathrm{x}$ \\
\hline & $\begin{array}{l}\text { Current } \\
\text { allowances }\end{array}$ & & & & $\mathrm{x}$ & & & $\mathrm{x}$ \\
\hline & $\begin{array}{l}\text { Current } \\
\text { administration }\end{array}$ & & & & $\mathrm{x}$ & & & $\mathrm{x}$ \\
\hline & $\begin{array}{l}\text { Current } \\
\text { coworkers }\end{array}$ & & & & & & & $\mathrm{x}$ \\
\hline & $\begin{array}{l}\text { Personal and } \\
\text { professional } \\
\text { identity }\end{array}$ & $\mathrm{x}$ & & & & & $\mathrm{x}$ & $\mathrm{x}$ \\
\hline
\end{tabular}

\subsubsection{Iterational influences: Past teaching experience}

Michelle felt that in the first school where she taught, she had much more freedom than what she feels she has now in WCPS. She even noted that at times, she would change the order of topics or units. However, this past taste of innovative agency was not enough to whet Michelle's appetite for regular curriculum making.

\subsubsection{Iterational influences: Past teacher education}

For Walt and Michelle, their teacher preparation programs were reportedly beneficial, but did not promote innovation or their structurally transformative agency.

Walt noted that he appreciated his teacher education program, and that he benefited in various ways from a technology application course, and from student teaching; however, he credited neither of these things with supporting his classroom innovation. 
Likewise, Michelle felt that her teacher preparation program was very comprehensive and that she felt prepared to teach at the end of it, but she did not suggest that this program helped her to innovate.

\subsubsection{Practical-evaluative influences: Current curricular allowances, expectations, or} mandates and current administration

Robert and Michelle have both been given curricular allowances, expectations or mandates that are supportive of innovation, as well as supportive administrators, but they have thus far remained unmoved regarding regular innovation in their everyday classroom practice.

Robert's curricular allowances and expectations, as given by his administration as well as the collaborative, could very well have moved him toward greater structurally transformative agency. While he does have plans to innovate more in the classroom, at the time of the interview, Robert was still not sold on innovating regularly. Robert noted that his principal wants teachers to be more engaging and to innovate in their classrooms, and that he and others are regularly encouraged to try new things. However, instead of latching onto his principal's vision, Robert expressed cynicism toward his administration's requests, feeling that they have "no idea what it feels like to be a teacher in one of these classrooms." He shared that he feels like his principal is "like everyone else in education" who wants teachers to be innovative, but without an understanding of the classroom dynamics that can be involved. Robert believes that if the administration were regularly in the classroom, their desire for teachers' innovation would look differently. He said: 
And so, when you're under that kind of pressure, when people are always coming up and telling you to, "Oh, why don't you do a big project?" or "Oh, why don't you put some flexible seating in your classroom?" or "Why don't you try this?" or "Why not that?" and it's like, you know, "Why don't you sit in here for five minutes and then tell me what I should be doing."

The freedom afforded Robert could be very encouraging of his exercise of structurally transformative agency, but thus far it has been ineffective to promote lasting change.

Michelle stated several times that her principal and assistant principal were supportive of her classroom innovation, even to the extent that they offered to find her the resources that she would need to carry out her designs; still, Michelle has chosen not to innovate in her classroom instruction, not believing that it is possible for her.

\subsubsection{Practical-evaluative influences: Current coworkers}

Many of the questions in the interview were geared toward participants having the opportunity to share about their relationships with their coworkers and administration. Michelle, unlike the other seven teacher participants in this study, only mentioned her coworkers one time, sharing that she found "commonality...with [her] other colleagues about what [they] could try to do within their school building" to reach the targeted group of students. While she shared this in a positive way, Michelle's coworkers were otherwise absent from her discussion about what influenced her innovative design and her regular classroom practice; thus, it seems that they have had little to no effect on her teaching in general, nor on her innovation. 


\subsubsection{Projective influences}

There were no projective influences that had a potentially positive effect on participants' structurally transformative agency, but only projective influences that had a clearly positive effect.

\subsubsection{The influence of personal and professional identity}

For Tami, Hannah, and Michelle, personal and professional identity could very well have played a role in increasing their structurally transformative agency, but it did not.

Tami only referred one time to the way that she views herself having an impact on her classroom instruction; she likely would not have mentioned her personal and professional identity as an influence at all, had I not asked a question particularly aimed at this in the interview. When asked, she shared, “ $[\mathrm{M}] \mathrm{y}$ personality is like I want them to have language arts skills, but I [also] want them to be good people, I want them to be prepared for success, and I think that my goals and my attitude toward the kids are the main things that influence my curriculum and I think that's how like, my true self, my true goals comes [sic.] through, is just, in what I'm trying to accomplish for the kids." Although Tami mentioned her personality as an influence, it was not her personality or professional identity that she continued to describe as influences at all, but rather, her goals for her students.

Hannah only mentioned her identity a couple of times, and when she did, it was to share that she is careful to remember that she is not a social worker or psychologist, but an English teacher. She takes social emotional aspects of learning into consideration when she is teaching, but does not major in them. In the other instance in which her personal and 
professional identity was mentioned, Hannah simply shared that by nature, she likes working with kids and people, but would rather work in the background than be in front of people when it comes to professional development. Hannah's personal and professional identity has not played a major role in her exercise of structurally transformative agency.

Michelle's personal and professional identity was shown to have some negative effects on her ability to exercise structurally transformative agency, especially in the way that she views herself as a veteran teacher whose practice is not in need of much change; she views herself as a source of educational wisdom for others, rather than needing it herself, and partially because of this, she has not seen a need to innovate in her classroom. On the other hand, it is apparent that Michelle's personal and professional identity could potentially increase her classroom innovation, but it has not yet done this. Michelle shared that teaching from a script feels "fake" to her, and that she "[doesn't] like to teach like that." She also shared that she tends to be known as an overachiever in her building: a teacher who goes above and beyond the expectations. Finally, Michelle described herself as a "guide" and an “engager." All of these aspects of Michelle's personal and professional identity would lend themselves well to her growing in structurally transformative agency, but their effect has not yet taken up residence in her everyday classroom practice.

\subsubsection{The influence of the collaborative}

Because the influence of the collaborative was positive for all participants' growth in structurally transformative agency, there were no participants for whom it was only potentially positive. It can be noted, though, that its effects certainly could have been more 
far-reaching for participants like Robert and Michelle, who have not yet become curriculum makers in their everyday instruction.

\subsection{SUMMARY OF INFLUENCES ON TEACHER PARTICIPANTS' STRUCTURALLY TRANSFORMATIVE AGENCY}

Table 28 demonstrates the trends apparent in the data regarding the influences on the teacher participants' structurally transformative agency. Those in white are influences that supported teachers' structurally transformative agency, as well as influences that could have constricted teachers' exercise of structurally transformative agency, but did not. Those in dark gray are influences that teachers perceived to be constrictive to their expression of structurally transformative agency and classroom innovation. The influences in light gray are those that were potentially supportive of teachers' structurally transformative agency, but did not affect it.

Table 28. (Potentially) Supportive and (Potentially) Constrictive Influences on the Teacher Participants' Exercise of Structurally Transformative Agency

\begin{tabular}{|c|c|c|c|c|c|c|c|c|}
\hline & \multirow[t]{2}{*}{ Name of Code } & \multicolumn{7}{|c|}{ Name of Participant } \\
\hline & & \multicolumn{2}{|c|}{ Tami Kellen } & Walt & Robert & \multicolumn{3}{|c|}{ Sydney Hannah Michelle } \\
\hline$\frac{0}{0}$ & $\begin{array}{l}\text { Past teaching } \\
\text { experience }\end{array}$ & 6 & 4 & 3 & 9 & 3 & 5 & 5 \\
\hline ث] & $\begin{array}{l}\text { Past teacher } \\
\text { education }\end{array}$ & 4 & 5 & 4 & 10 & 3 & 9 & 2 \\
\hline 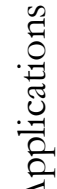 & $\begin{array}{l}\text { Current curricular } \\
\text { allowances, } \\
\text { expectations, or } \\
\text { mandates }\end{array}$ & 4 & 10 & 6 & 14 & 5 & 3 & 9 \\
\hline 4 & $\begin{array}{l}\text { Current } \\
\text { administration }\end{array}$ & 12 & 4 & 6 & 12 & 5 & 5 & 4 \\
\hline$\frac{0}{7}$ & Current coworkers & 5 & 12 & 6 & 9 & 3 & 7 & 1 \\
\hline$\vec{z}$ & Current students & 2 & 14 & 2 & 19 & 14 & 3 & 9 \\
\hline & Goals for students & 18 & 13 & 12 & 17 & 18 & 10 & 12 \\
\hline
\end{tabular}




\begin{tabular}{|l|l|c|c|c|c|c|c|c|}
\hline & $\begin{array}{l}\text { Influence of personal } \\
\text { and professional } \\
\text { identity }\end{array}$ & 1 & 25 & 10 & 13 & 2 & 2 & 10 \\
\hline $\begin{array}{l}\text { Influence of the } \\
\text { collaborative }\end{array}$ & 14 & 15 & 10 & 11 & 11 & 9 & 6 \\
\hline
\end{tabular}

The vast majority of participants reported that the nine influences supported their exercise of structurally transformative agency or did not constrain it, even if they had the potential to do so. This was the case for Tami, Kellen, Walt, Sydney, and Hannah. Robert viewed most of the influences as constrictive of his ability to exercise innovation in the classroom, even though he acknowledged that the current allowances at his school and his administration would have supported innovative efforts. Similarly, Michelle described most of the influences as being either constrictive of her ability to innovate or potentially supportive of her innovation, but without effect; such was the case with the influences of her past teaching experience, past teacher education, current administration, and current coworkers.

The influences of current allowances and personal and professional identity on Michelle's exercise of structurally transformative agency are shown in medium gray, because she perceived these influences to be both constrictive and potentially supportive in various ways; ultimately, they did not increase structurally transformative agency in her practice.

A few other participants perceived various influences to be both supportive of their expression of structurally transformative agency and potentially constrictive in different ways; ultimately, these teachers were able to exercise structurally transformative agency due to and in spite of these influences, which are all shown in white. Kellen viewed current coworkers and current students as both supportive influences and potentially constrictive influences in different ways; for Sydney, current students were seen as both a supportive and 
a potentially constrictive influence; and Hannah viewed her current coworkers in the data as both supportive and potentially constrictive of her exercise of structurally transformative agency.

Many of the influences that propelled agency in some teachers or did not keep them from exercising structurally transformative agency were the same influences that Robert and Michelle allowed to keep them from exercising structurally transformative agency, whether they viewed these influences merely as constrictive or as potentially supportive. The nuances of these findings, their relationship to the literature, implications for teachers, schools, and teacher preparation programs, and suggestions for further research will be taken up in the final chapter. 


\subsection{DISCUSSION AND CONCLUSION}

In this chapter, I first detail the types of impacts that various influences had on the teacher participants' exercise of agency, focusing especially on structurally transformative agency, and connecting these trends both to the literature and to the observations that Gwen shared with me in the interview. I then move toward a conceptualization of structurally transformative agency, based on the experiences and revealed patterns of response to various influences by teachers who exercise structurally transformative agency in their everyday practice, as opposed to those who do not. Finally, I suggest several implications of this study for teacher education programs, schools, teachers, and further research, to the ends that teachers might be increasingly prepared and supported in their exercise of structurally transformative agency, and that students would benefit from instruction that is responsive to who they are, how they learn, and their own development of agency.

\subsection{CATEGORIES OF INFLUENCE ON TEACHER AGENCY}

The teacher participants in this study certainly experienced different trends regarding their development of structurally transformative agency and the influences that supported or constrained this development. Some teachers (Tami, Kellen, Walt, and Sydney) experienced great change in their exercise of agency, moving from curriculum transmitters who

maintained institutional mandates and structures to curriculum makers who designed 
instruction themselves; others (Robert and Michelle) remained secure in their exercise of structurally reproductive agency or a lack of agency throughout their career, not venturing into curriculum innovation unless it was mandated, and sometimes avoiding it even when it was encouraged by their administrators; still another (Hannah) expressed structurally transformative agency throughout her career, but moved in her agency from being focused on her own practice to focusing on the agency of other teachers in her school.

Interestingly, similar influences often had very different impacts on these participants. For example, all of the teachers claimed to have administrators who were supportive of their innovation; the principal of Applewood hired Gwen to "help teachers innovate; the principal of Cromwell was the first to sign his teachers up for the collaborative; the principal of Whitfield excitedly welcomed Hannah's ideas for her pathways project and invited her to be a part of meetings with the leaders of the schools; and both Michelle's principal and assistant principal made it clear that they would do everything in their power to help her innovate in her classroom. For most of the teachers, this administrative support was reported as crucial to their feeling the freedom to innovate, with even the most agentive teachers using words like 'permission' to describe that which encouraged them toward curriculum making. For some, though, a more critical stance was taken toward this administrative support; Robert repeatedly noted that if school leaders really understood what conditions were like in the classroom, they would not expect teachers to use 'newfangled' strategies; Michelle simply did not see her administrators' support as sufficient to induce her to take the leap into classroom innovation, because other factors of her teaching context spoke more loudly.

While several of the influences had different impacts on teachers' exercise of structurally transformative agency, there were also several similarities found among teachers 
who exercised this type of agency, as well as among those who did not. Transformative agency was found to be ecological, collective, and emergent, and this is seen clearly in the trends that I detail below regarding the ecological influences treated in this study. As I share these trends, I also connect them with the literature.

\subsubsection{Past teacher education and teaching experience}

Several of the teachers in this study viewed their teacher education as having been supportive of, but not extremely impactful to, their agency. Tami, Walt, and Sydney all had positive things to say about their teacher preparation programs, none of which were intimately tied to their ability to innovate. Michelle, likewise, noted the helpfulness of her program to prepare her, but Michelle does not practice regular classroom innovation, nor does she value it. Kellen did not feel as though her ability to innovate was hindered by her teacher education program, but she also did not feel as though her program helped her to develop as a teacher, and certainly did not feel that her ability to innovate was supported by her program. All of the above-mentioned teachers completed traditional or alternative certification routes of preparation. Robert, who was accepted to teach as a 'non-traditional' teacher after passing the Praxis II exam, never having completed a teacher education program, but rather an Ed.D. and years of military experience, noted that he did not feel prepared to teach when he began his career in education. He shared that he struggled to "inject fun" into learning and felt as though he could have benefitted greatly from more classes focused on specific teaching methods. Hannah alone, who completed a teacher residency program, viewed her teacher education as highly impactful to her agency, saying that she appreciated the opportunity to apply her studies directly to a classroom setting 
throughout her program and to receive "live in-the-moment coaching from a classroom teacher mentor and professors alike." Hannah felt as though she began her career much better-prepared than most of her colleagues, and a large part of her planning for the professional development pathways at her school was influenced by her "own personal bootcamp," as she pulled many materials from the teacher residency program to prepare for it.

The literature supports the phenomena experienced by these teachers. First, Dierking and Fox (2013) found that when teachers were given more and specific tools and resources to use, they felt empowered to innovate in their instruction. Robert's lack of innovation may be related a lack of confidence to do so, based on the absence of his teacher education and the knowledge of the specific methods that he wished he had learned. On the other hand, the agentive teachers that looked favorably upon their teacher education mostly noted their learning of specific methods as that which stood out to them; for Tami and Sydney, classroom management methods, for Walt, methods for using technology, and for Hannah, a plethora of methods that she garnered from her program for instruction and assessment.

Moreover, the literature supports the idea that knowledge alone does not boost agency, but that the systems of support that are available to teachers, when coupled with knowledge, are integral. Again, in their study of teachers in a National Writing Project professional development initiative, Dierking and Fox (2013) found that support systems were more valuable teachers than the techniques that they learned during their time in the institute. Robert had surely received much knowledge during his Ed.S. and Ed.D. programs, but because these programs were completed online, systems of support were lacking, thus having a probable impact on his lack of structurally transformative agency. Teachers who did perceive their teacher education to be helpful emphasized the support of their co-teachers 
and mentors. Tami and Sydney appreciated the way that their co-teachers allowed them to take control of the classroom; Walt felt that he gleaned a lot of strategies from his coteacher; and Hannah shared repeatedly that her co-teacher and the mentorship of her professors had a great impact on her growth as a teacher.

Ellis and McNicholl (2015), who consider the state of higher education in England, note that " $[\mathrm{t}]$ he fragmentation of ITE [Initial Teacher Education] programs has frequently been identified as a barrier to their success in preparing teachers" (p. 143). They voice concern for the theory-practice divide caused by taking classes in institutions of higher education and then, separately, teaching with supervision in neighboring schools. They believe that this divide "limits the full and rich appropriation of research-informed ideas in the practical work of teaching" (p. 143), suggesting that some solutions to this problem may be holding lectures on school premises, as well as initiatives like internships or teacher residencies, where the majority of the program is spent in the workplace. They emphasize the support and feedback from a mentor, along with "a contribution from an HEI [Higher Education Institution] that 'wraps around' the work-based learning of the student teacher' (p. 143). This rationale for a more comprehensive and beneficial teacher education experience speaks directly to the reasons for Hannah's esteem for her teacher residency program, and to Kellen's wish to have experienced something similar.

It can be noted that the expertise and confidence that are agency-boosting for teachers are gained also through their teaching experience. Many of the teachers in the study shared that it was through their past professional experiences of learning about their students, trying and failing in various instructional endeavors and succeeding in others, that they felt they were able to develop in agency. Similarly, In Buchanan's (2015) study, she 
found that teachers' agentive actions of stepping up and pushing back in the face of challenging policy measures were greatly influenced by their past professional experiences.

It is important to recognize that teachers who regularly exercised structurally transformative agency viewed their past teaching experience as a tool by which they could better their practice, viewing failures and challenges as opportunities to grow and try new things until they were successful; for Robert and Michelle, who did not exercise structurally transformative agency in their everyday classroom practice, their past teaching experiences were viewed as easier times to which they constantly compared their current, more challenging situations, thus constraining their ability to exercise creative agency; this was due, not to the ecological influences of their experience, but to their own perspectives, for some of the other teachers had had similar past teaching experiences as Robert and Michelle, yet their innovative agency was not hindered by them.

\subsubsection{Perceived professional spaces}

Teacher participants' perceived professional spaces, including their perceptions about the curricular allowances, expectations, or mandates in their districts and schools, their administration, and their coworkers heavily impacted their exercise of structurally transformative agency. I emphasize the word 'perceived,' because sometimes teachers' perceptions of their professional space were inconsistent with the space they described elsewhere in the data, while in other cases, the perceived and actual professional spaces of teachers seemed more closely aligned.

In some of the data in this study, constrictive professional spaces functioned to do just this: constrict. Robert repeatedly voiced that his colleagues' poor opinions of the 
collaborative and of the innovations that he was attempting caused him to feel as though he should not innovate, for fear that he might lose control of his classroom in the midst of trying new things, and his colleagues might look down on him for it. Robert, not surprisingly, kept the enactment of his innovative instructional plan to only two weeks of the school year, being unwilling to risk more time on something that he felt would not be effective. Similarly, district curriculum mandates and their allotment of resources for teachers only at certain times of the year convinced Michelle that she was unable to innovate in her classroom. So powerful were these factors to her, that even during the collaborative and with supportive administration, she was unwilling to exercise innovation in her classroom. Much of the literature supports the fact that constrictive professional spaces have a negative impact on teacher agency. Strict mandates as to how teachers use materials (Vaughn \& Faircloth, 2011); limited access to material resources (Starkey, 2010); the inequitable distribution of resources to teachers (Bieler et al., 2017); curricular mandates that excluded the use of creative teaching practices (Williams, 2018) and technology use (Starkey, 2010); and scripted curriculum in general (Pease-Alvarez \& Samway, 2008) have been shown to constrict teachers' agency and creativity in the classroom.

Nonetheless, constrictive professional spaces do not determine teachers' ability to exercise agency. In this study, teachers often described the ways that they overcame potentially constrictive professional spaces in order to innovate and do what they felt was best for their students. For example, Kellen and Hannah both noted that they experienced difficult dealings with some colleagues regarding their desire to innovate, and that certain colleagues looked down upon teachers who strayed from the status quo, going above or beyond the department, school, or district expectations. This constraining aspect of Kellen's and Hannah's professional space, however, did not dictate their ability or willingness to 
innovate. All five of the teachers who regularly exercised structurally transformative agency had to overcome, in some way or another, the pressures that come with challenging and resisting prescriptive curriculum, especially because they taught in tested content areas.

However, it is notable that all of these teachers had administrators, some coworkers, and even district supervisors who were supportive of their innovation. Wang, Mu, and Zhang (2017) note that in their study, "strong teacher agency was found in educational organizations with horizontal ties, reciprocal communications, and limited control over teachers' work; whereas hierarchical structures and bureaucratic management were found to constrain teacher agency" (p. 116). Even though the teachers in this study who regularly exercised transformative agency faced various challenges, such as unsupportive colleagues and prescriptive curriculum mandates, the supportive aspects of their professional spaces outweighed those that were constrictive, as they all had very high levels of administrative support, some supportive coworkers, and the permission to innovate from both their schools and, during the collaborative's second year, from the district, who funded it. BakerDoyle and Gustavson (2016), Oolbekkink-Marchand et al. (2017), and Pease-Alvarez and Samway (2008) found in their respective studies that even the most agentive teachers felt that they needed 'permission' to innovate. Likewise, Rivera Maulucci et al. (2015) found that only when deeper social structures of the teachers' school experiences were made more malleable, were they able to innovate. While it is certainly possible that teachers exercise structurally transformative agency without the support of their district, administrators, or coworkers, all of the teachers in this study who exercised structurally transformative agency were, for the most part, well supported in these areas, and considered this support to be integral to their exercise of innovation. 
Notably, all of the teachers who regularly exercised structurally transformative agency not only felt supported by several of their coworkers, but they also grew in their expression of agency as they came to see themselves as capable of having an impact on their colleagues' professional development. The teachers who were in the collaborative during the first year got "a taste in their mouths for leadership," and began to mentor other teachers, to present at conferences, and in some cases, to lead their departments. Sydney's agency in her classroom grew as she realized that she was not only gleaning insight and strategies from her co-worker, who was more seasoned, but that her coworker was also learning from her. Finally, Hannah's pre-existing agency developed to a new level when she realized that she could have an impact not only on her own practice, but on the agency of all of the other teachers in her building. In a study of 3 Australian urban primary school teachers, Simpson (2017) found that as they worked in a collaborative inquiry group together, they realized that they were supporting the professional development of their colleagues, which, in turn, boosted their agency. Teachers' agency not only developed because of the support of their professional spaces, but because of the impact that they found they could have on their professional spaces.

\subsubsection{Students and goals for students}

All of the teachers in this study worked with a similar and diverse demographic of students at their respective schools, and most of these teachers acknowledged that the students they taught would benefit from different instructional approaches than those that might be effective in other contexts. Tami, Kellen, and Sydney all clearly depicted classroom innovations that they designed in response to their students' needs for relevant, engaging, 
and contextually sensitive instruction, exercising structurally transformative agency to the end of meaningful student learning. These, along with the other teachers who exercised structurally transformative agency in this study, did not focus on their students' academic weaknesses or poor behavior, but on how to instruct in such a way as to be supportive of students' interests, motivations, backgrounds, and futures. Robert and Michelle clearly articulated their care for their students, but seemed to view them as projects to be molded to their liking rather than fellow human beings with their own agency to exercise. Robert repeatedly cited students' backgrounds, apathy, poor academic abilities, and misbehavior as reasons why innovation was risky to him, and Michelle focused her Norton Nights project on working with parents of students whom she felt needed to improve academically and behaviorally.

Teachers' goals for students seemed to follow their perspectives of students; Tami, Kellen, Walt, Sydney, and Hannah emphasized such goals as curiosity, inquiry, hands-on learning, real world application of content, engagement, choice, voice, and student agency as they described their instruction, while Robert and Michelle both emphasized their desire that students might become better people, and that they would improve academically and behaviorally.

Chisholm et al. (2019) noted in their literature review that teachers who exercised agency usually cited engaging students in learning and advocating for students' diverse identities as the primary student-focused reasons for their agentive action. Many of these teachers desired to enhance student voice (Bender-Slack, 2010; Lopez, 2011) and to challenge stereotypes about students (Allen, 2015). Only one study out of the 21 reviewed found that agency was being exercised namely to improve students' outcomes in external measures such as standardized testing (Miller et al., 2017). Stagg-Peterson (2012) found in a 
study of writing instruction that teachers who took a skills orientation to writing instruction exercised little agency, while teachers with critical, sociopolitical orientations adopted more agentive stances.

This literature aligns with the findings of this study, in that Robert and Michelle, who exercised little agency, focused more on students' growth in academic and behavioral skills, even in the enactment of their innovative designs. Robert wanted to see how his innovations might impact students' test scores, and Michelle desired for students to improve academically and behaviorally, and to be 'accountable.' On the other hand, the teachers who exercised structurally transformative agency tended to take more critical approaches, desiring to empower students with culturally relevant materials and in order to disrupt systems of oppression that are often promoted through scripted curriculum.

\subsubsection{Personal and professional identity}

The influence of teachers' personal and professional identities, as revealed in the data, provided unique insights. Robert and Michelle, who did not regularly exercise innovation, both viewed themselves as curriculum experts who had more to offer to the field of education than they had still to learn from it. On the other hand, the teachers who regularly exercised structurally transformative agency, apart from Kellen, hardly mentioned their personal or professional identity as an influence on their innovation, save for Walt, who repeatedly voiced that he viewed himself as non-creative. However, Walt's view of himself as lacking creativity seemed to propel him to seek the very things that allowed him to develop in structurally transformative agency: the help of Gwen, the collaborative, and other coworkers with whom he regularly met. Kellen, who exercised perhaps the most structurally 
transformative agency of all, unlike these teachers, cited her identity 25 times throughout the data as having been impactful to her decision and ability to innovate. So highly in tune was she with what she could and could not let herself do on the basis of her strong convictions and her understanding of herself as a teacher and as a learner, that personal and professional identity functioned as the influence with the greatest reported effect on Kellen's practice of innovation. She continually shared her belief that even apart from the influence of the administration or the collaborative, innovation was "always in [her]," and that her transformative practice would have unfolded eventually, regardless of other ecological factors. Her disgust with teaching the way other people teach, her disdain for direct instruction, her own need for movement and interaction with the outdoors, her understanding of herself as a 'rogue' educator who doesn't fit into a 'mold' or a 'box,' and her deep desire to know that everything she does meets her own needs and her students' needs, drove her instruction.

Day (2018) stresses in his chapter on agency, emotions, and resilience, and their relationship to professional identity, that oppressive structures and discourses alone do not determine how individuals feel or act, but rather, teachers' efficacy and agency are "part of an on-going, complex interactional dynamic between individual strength of (moral) purpose and the emotional dynamic of workplace and external social and policy environments" (p. 64). Day argues that it is necessary for teachers to sustain a sense of positive professional identity in order to succeed over time as professionals and to navigate the shifting landscape of their workplace. Tao and Gao (2017) similarly argue that teacher identity commitments, or their resolve to be the kind of teacher that they want to be, is powerful to inform their agentic actions, based on their study of teachers in China undergoing curricular reform. The challenges faced by the teachers in the midst of this change did not prevent the participants 
with firm identity commitments from engaging in the research activities that they believed to be important. The authors contend that while teacher agency has been recognized to inform teacher identity construction, teacher identity commitment conversely plays a role in teachers' ability to exercise agency.

Kellen's structurally transformative agency was evidently informed by her strong identity commitments to be a relevant, engaging and innovative teacher, which allowed her to maintain the exercise of agency even in the midst of challenges to it.

\subsubsection{The collaborative}

Notably, the collaborative had supportive effects on all teachers' expression of structurally transformative agency, even though for Hannah and Michelle, it was enacted outside of classroom, and for Michelle and Robert, it was short-lived.

It is worth noting that Tami, Kellen, and Walt, who were a part of the original collaborative cohort during the 2017-2018 school year, described its impact on their practice in especially sweeping terms: Tami described how the community and support that she received in the collaborative were critical to her process in classroom innovation; Kellen claimed that "the collaborative impacted [her] design heavily," and that the permission it granted her to innovate was what she needed in order to change the course of her career; and Walt, perhaps the most influenced by the collaborative of all three, shared that its impact on him was 'lasting' and "shifted [his] whole pedagogical practices [sic.]." He shared that he felt like his eyes were opened to being more open, vulnerable, innovative, and that because of his experience being mentored by Gwen, he decided to mentor other teachers through a similar process. It is evident that the collaborative had a far-reaching impact on all three of 
these teachers, who were moved to continue to innovate, to become mentors, and to lead professional development and their departments.

Gwen noted some discrepancies between the experiences of the teachers in the small Applewood cohort during the collaborative's first year, and those who were a part of the collaborative during its second year, when it was co-opted by the district and opened to over fifty teachers from five more schools. She shared that at Applewood, "all the teachers who participated were really in it...they were really motivated, they were excited to be a part of it." She could only say this in reference to "about half of the teachers" involved during the second year, since, in many cases, the principals of the five schools encouraged teachers to participate, rather than teachers choosing to participate for themselves. "[S]o they didn't necessarily know what they were signing up for," she said of the teachers from year two. "And for some of them, that was like, a welcome surprise. Or it was like, 'Oh, wow, this is cool.' You know? For others, it was like, 'What...am I doing here?'...So, that created some...frustration.”

Gwen shared that she felt that the Applewood cohort had perhaps gleaned more from the program than did the teachers during the second year. When I asked her why, she cited the reasons above, but also went on to share that the relationships looked differently. Gwen was employed at Applewood during the first year of the collaborative, and saw the teachers almost daily, in addition to their Friday meetings at a local pub. "[]t became this...family, you know, environment, where we literally were like, we were friends. And we were engaging with each other in...a very...informal way." She felt, in retrospect, like her proximity to the teachers during the first year was one of the more significant reasons for the collaborative's impact; she was able to regularly check in with teachers and coach them, helping to facilitate their processes of innovation and even, at times, teaching alongside of 
them. To the credit of the mentors from the collaborative's second year, Gwen acknowledged that they gave their best effort to help teachers, but believed the fact that they did not teach in the schools where they served as mentors was a weakness of year two, as well as the fact that most of the mentors had not been through the collaborative as mentees before. Gwen felt like some of the mentors wanted to be a part of the program "as a résumé pad. Some of them wanted the thousand-dollar stipend. Some of them didn't really know what they were showing up for, but they are the kinds of teachers who do everything. Right? So, it was like, the profile of the mentor was very different."

In spite of the fact that the teachers from the collaborative's first year might have benefitted more from the program, the other four teachers in this study all noted positive influences that the collaborative had on their practice or innovative designs; as Gwen shared, some more than others. Sydney stated that being a part of the collaborative "really just transformed the whole way that [she goes] into teaching" as well as the way that she views her classroom. She felt that the collaborative allowed her to begin to see the scripted curriculum as an outline rather than a mandate, and appreciated her mentors greatly. Hannah's experience in the collaborative did not impact her classroom instruction or her beliefs about teaching, but it did "give [her] confidence to advocate for a bigger change" in her school. She felt empowered by the shadowing experience to act on behalf of the other teachers and students in her building, and through the collaborative, was given the time, space, and tools to do so.

Although Robert felt that he was 'volun-told' to be a part of the collaborative and was skeptical of the experience, believing that he opened himself up to 'exposure' by allowing for innovation and flexibility in his classroom, he also noted that he planned to continue to innovate, and that his innovation had had some positive effects on students. The 
impact of the collaborative on Michelle was minimal, and she continued to be noninnovative in her classroom, but she did describe the collaborative as 'eye-opening' and was able to design her innovative Norton Nights project through her time in the collaborative.

It is apparent that for those for whom the collaborative was especially impactful on their classroom practice, there was power in relationships - relationships that were encouraging, facilitated thinking about curriculum in new ways, provided a sounding board, and consisted of mentorship and coaching, and even friendship. Those for whom the collaborative was less impactful on their everyday classroom practice did not emphasize the influence of the relationships that were cultivated during the year, but rather felt they benefited from the opportunity to innovate and to see their students and schools through another lens.

These findings are in keeping with the research of Dierking and Fox (2013), who found in their study of teachers in the NWP Institute that teachers valued the networks of support that were made available to them more than the innovative methods and techniques that they learned. New knowledge, in itself, was not sufficient to enhance agency, but when coupled with multi-level systems of support, teacher agency increased. Puzio et al. (2017) share stories of teachers' 'creative failures' when attempting critical pedagogies, noting that disrupting the status quo "cannot and should not be done alone" (p. 231). Collaboration with others helps teachers to persevere in innovation, which inevitably involves difficulty and failure. Many of the teachers in this study noted that collaboration was critical to their perseverance in agency, and that it was the other teachers with whom they worked who gave them new ideas, encouraged them on hard days, and convinced them that it was okay to fail if they were pursuing innovation for the good of their students. 
Tao and Gao (2017) suggest a reason for why teachers like Robert and Michelle did not experience much growth in agency during their participation in the collaborative. Similar

to the studies in which it was shown that the process of curriculum making actually enhances teacher agency, Tao and Gao (2017) note that teachers in their study who chose not to rely on textbooks, rather spending time creating and updating curriculum materials in response to student needs "developed a strong sense of agency as they took agentic actions to improve their teaching and gained increased confidence in their teaching skills" (p. 351). Whereas most participants chose to pursue innovation throughout the whole collaborative year, Michelle and Robert only enacted innovative plans for a short period of time; Michelle, on the two Norton Nights, and Robert during the last two weeks of school. It is possible that if these teachers had chosen to innovate more consistently, more growth could be seen in their exercise of structurally transformative agency.

\subsection{CONCEPTUALIZING STRUCTURALLY TRANSFORMATIVE AGENCY}

Trends are apparent with regard to how teachers in this study who exercised structurally transformative agency in their everyday practice responded to various influences, as opposed to those who did not. In the figures below, I highlight the core attributes of and supportive influences on the teachers who regularly exercised structurally transformative agency, as opposed to the attributes of and influences on those who did not regularly exercise structurally transformative agency in their practice. 


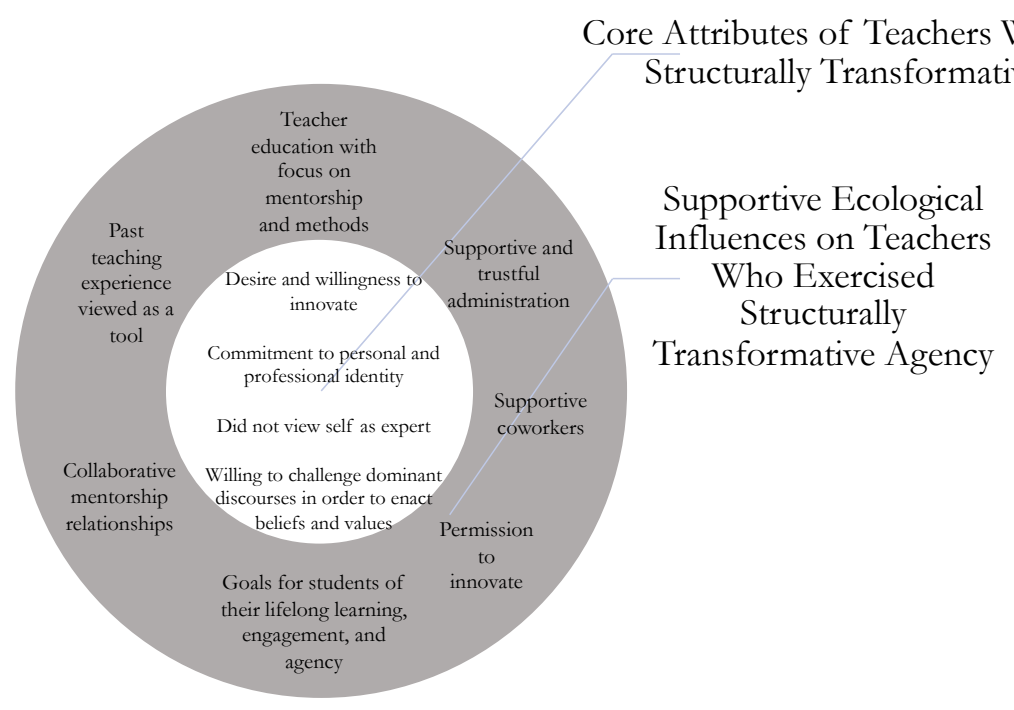

Figure 10. Attributes of and Influences on Teachers Who Exercised Structurally Transformative Agency

The teachers who regularly exercised structurally transformative agency in their classroom practice tended to share several core attributes, as well as similar ecological influences or responses to ecological influences. Regarding internal attributes, these teachers were desirous of innovation and willing to take steps to involve themselves in innovative initiatives; some had a strong commitment to their personal or professional identity; they did not view themselves as experts; and they were willing to challenge dominant discourses and to potentially face conflict in order to enact their beliefs and values. The ecological influences that these teachers shared or took up similarly were many: They viewed their past teaching experience as a tool from which to learn, instead of a situation to which to compare their current circumstance; their teacher education tended to have a focus on mentorship relationships and the learning of specific methods, though for some it was not memorable nor helpful; their administration was supportive and trustful, as were most of their coworkers, all of whom gave teachers permission to innovate; the goals of these teachers for their students were centered on lifelong learning, engagement, and agency; and these 
teachers tended to emphasize the relationships that were cultivated in the collaborative as the influence of greatest impact during their participation in it.

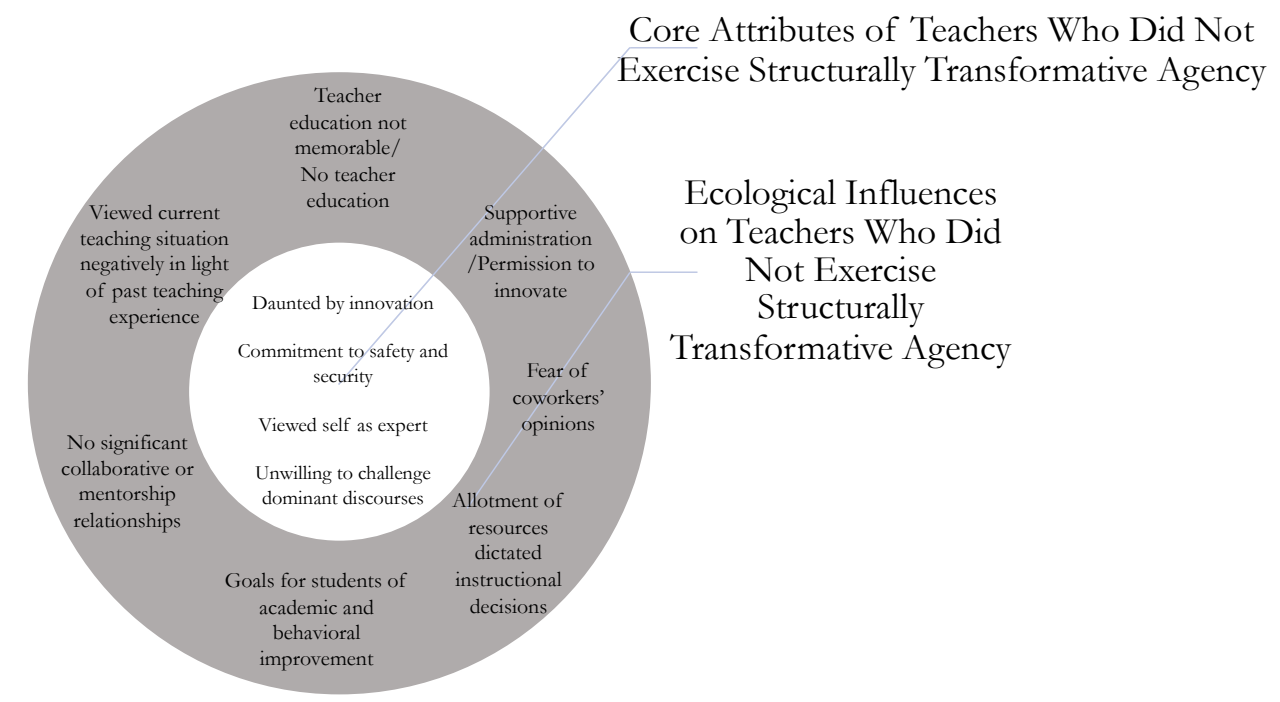

Figure 11. Attributes of and Influences on Teachers Who Did Not Exercise Structurally Transformative Agency

For the teachers who did not exercise structurally transformative agency in their everyday classroom practice, there was, likewise, a series of trends that they shared with regard to both internal attributes and ecological influences. These teachers were daunted by the thought of innovation, either for fear of losing time, control, or the esteem of their colleagues; they were committed to safety and security; they viewed themselves as experts, and they were unwilling to challenge dominant discourses. Ecologically, these teachers had supportive administrators and permission to innovate, but chose not to; they viewed their current teaching situations and students negatively in light of their past teaching experiences; their teacher education was either nonexistent or not particularly memorable; they did not often mention their coworkers, but when they did, it was to suggest that their coworkers expected them to maintain status quo structures; the allotment of various resources dictated 
their instructional decisions, whether access to technology or to lab materials; their primary goals for their students had to do with academic and behavioral improvement; and finally, they did not note any significant mentor relationships.

The differences among the teachers who did and did not exercise structurally transformative agency look to be many in the figures shown above, but they actually come down, mostly, to teachers' perspectives about themselves and their contexts, and their willingness to cultivate relationships. The teachers who did not regularly exercise structurally transformative agency (Robert and Michelle) did not have contextual circumstances that differed greatly from those of the teachers who did habitually exercise structurally transformative agency: they had similarly supportive administrators who gave them permission to innovate, they taught similar demographics of students and similar subjects in the same district with the same curriculum standards, and they were involved in the same professional collaborative. However, they chose to be ruled by feelings of constraint and fear, rather than being willing to risk failure; they let the resources to which they did not have access keep them from taking advantage of the resources to which they did have access; they viewed themselves as experts without need for the help or collaboration of others; they viewed their students negatively and created goals for them that were focused more on fixing them than on empowering them. These findings reveal that while ecological influences can certainly impact teachers' exercise of structurally transformative agency, it is often their internal perspectives that dictate how external influences are perceived and taken up to enhance or to hinder their innovation and development of agency. Nevertheless, it is still worth noting that these two teachers did not mention having a particularly memorable or helpful teacher education experience, if they had one at all, and that they had no close mentorship relationships to speak of, whether by happenstance or by choice. 


\subsection{IMPLICATIONS FOR TEACHER EDUCATION, DISTRICTS, SCHOOLS,}

AND TEACHERS

The findings above suggest that the ecological influences that shape teachers' agency are significant, especially with regard to professional relationships: with administrators, teacher educators, mentors, colleagues, and other collaborative partners. For the teachers who regularly exercised structurally transformative agency, these relationships were crucial. Although all other contextual circumstances were similar among the seven teacher participants in this study, the lack of positive relationships in the teaching lives of Robert and Michelle seems to be one reality that might have impacted their lack of classroom innovation. However, as stated above, it is possible, even probable, that these types of relationships were available to Robert and Michelle, as they, at the very least, had supportive administrators, and many mentors, colleagues, and collaborators available to them in the innovative program. Yet, they did not take advantage of the opportunities that these relationships offered, and they remained in their states of structurally reproductive agency or non-agency, save for the short-lived enactment of their innovative designs. Based on these findings, I suggest here some implications and potential directions for teacher education, districts, schools, and teachers. To do this, I draw on several of Gwen's ideas as a way to connect to the literature and to underscore the implications derived from this study.

\subsubsection{Implications for teacher education}

Ellis and McNicholl (2015) state, "if we want to get the discipline of Education right, we need to get teacher education right" (p. 124). They recognize the systemic problems in 
education that begin with the state, and filter into institutions of higher education and finally, to teachers and schools. Citing Gutmann (1999) and Furlong (2014), they note that the "commitment to the "contestability of knowledge" (Furlong, 2014) that is supposed to be uniquely characteristic of universities has all but been quenched completely by top-down control of education by the state, which "creates in populations the expectations of being continually guided by the state to the detriment of their human agency and creativity" (p. 125). Gutmann (1999) argues that a society may be described as democratic only to the extent that "citizens and their accountable representatives offer one another morally defensible reasons for mutually binding laws in an ongoing process of mutual justification" (1999, p. xii). It is clear that while several of the teachers in the study were fighting for democratic practice, agency, and creativity, it was also far too easy for teachers to be curriculum transmitters who felt justified in their transmission, because they were trained to believe that offering prepackaged materials was best for their students, and that the state and district had control over them.

In response to this reality, Zeichner, Payne, and Brayko (2012) argue for the concept of 'hybrid spaces,' or social environments in which actors from different fields come together to work in collaboration; they believe that within spaces like these, new knowledge and practices are likely to emerge. Ellis and McNicholl (2015) support the similar concept of 'coconfiguration,' or “an attempt to conceptualize collaborative partnerships between multiple organizations that have different priorities and primary objects but that come together to work on particularly 'knotty,' socially complex and challenging problems” (p. 135). They suggest that these partnerships require social spaces that are designed for trustful collaboration and a shared commitment to change, that new knowledge might be created for the good of the public. It would behoove teacher education programs to support such 
initiatives as the teacher residency, of which Hannah was a part, or the innovative professional collaborative, both of which were 'hybrid spaces.' As mentioned before, the idea of holding teacher education classes on school premises is also supported, and these courses could be considered as 'hybrid spaces' as well (Ellis \& McNicholl, 2015).

Ellis and McNicholl (2015) also argue for the development of collective creativity and professional creativity in teacher education, saying "collective creativity is a key criterion of professional work and professional creativity is a defining characteristic of the professionality of teaching” (p. 134). They suggest that a central focus of teacher education should be the Vygotskian concept of intellectual interdependence, or the "process of construction of new ideas through the transformation of old ones in a communicative process" (Valsiner \& van der Veer, 2000, p. 12). Ellis and McNicholl (2015) believe that if professional creativity were to become a focus of teacher preparation programs, it would result in greater innovation and agency for teachers. They write, "[T] hrough an induction to the profession's systems of ideas and their modes of interrogation, the professional teacher is able to respond to unpredictable situations with new ideas and practices on an independent basis but drawing on a shared, collaboratively built knowledge base and, potentially, contributing something of significance to it" (p. 134).

Simpson et al. (2018) also argue for pre-service teachers to be introduced to the concept of agency and given explicit support for their development in it, as they found in their study that when this support is given, teachers gain more potential to innovate in their instruction. To give teachers the "skills, knowledge and dispositions to lead the changes that are needed" (Furlong, 2015, p. 38) should be a priority of teacher preparation programs. Part of this introduction of pre-service teachers to agency may be found in Tao and Gao's (2017) suggestion that teacher educators "guide student teachers to become more aware of their 
personal resources and learn to capitalize on them to seize available contextual

opportunities" (p. 354). Practice in mobilizing both personal and social resources to exercise agency, it is argued, can prepare teachers for their careers in shifting educational contexts (Tao \& Gao, 2017).

Ellis (2013) acknowledges the difficulty of many of the suggestions above, saying:

In terms of the current relationships between university education faculty and school teachers, this aspiration for the collaborative exercise of different agencies presents a formidable challenge, not the least of which is a risk associated with the general approach which Engeström describes as 'paternalistic manipulation.' But the challenge also extends to school teachers who must also be willing to give up their rugged or 'heroic' individualism and the tacit wisdom of the 'craft' in order to gain greater control over their own activities and their development through an active engagement in the production of new knowledge. (p. 213)

Teacher preparation programs may be able to assist teachers in gaining greater agency in more ways than those mentioned above, some of which Gwen, the founder and lead mentor of the collaborative, shared. She noted that in teacher education programs, "We don't spend time talking with teachers about their motivations while they're there...Like, really thinking it out. Who I am as a teacher, what matters to me, how do I approach teaching?" She believes that continually having conversations like these with teachers may foster agency.

Gwen also argued for the importance of student teaching opportunities in which teachers are given control of the classroom and are placed with mentors who are able to help them reflect on their successes and failures. She described her own experience of student teaching as formative, saying:

I had an amazing mentor who's still a dear friend to me to this day. And she literally, I was teaching the full class the second week of my experience in student teaching. Like, she literally, 'Okay, here's your class.' And I had a full section. And I would come in with these crazy ideas, and she would be like, 'Okay, let's try that.' Even if she knew it was gonna fall apart. And then she would coach me through reflecting. She would say, 'Okay, well that didn't work out. What happened?' And we would 
talk about it, but...I had the space and freedom to try. And...she was my same mentor my first year of teaching, and same thing. Same process. Like, I would fall, and I would fail, and she would talk me through it.

She noted that she does not believe this formative process happens often enough in WCPS. Speaking of Michelle, a seventeen-year veteran still bound to the scripted curriculum, Gwen noted that she thinks the growth of teachers like Michelle is stunted in the very beginning of their career. She said:

You'd have these brand-new teachers... and they would be told, 'Do what so-and-so does. 'Take their PowerPoint and do exactly what they do.' And while I understand... first-year teachers are getting their feet underneath them, at the same time, you are doing them a disservice. You are teaching them how not to make decisions for themselves. Right? And...that teacher at Norton...she's a veteran teacher. And she's been getting her box of curriculum for god knows how long, and now she doesn't know what to do with herself when it comes planned.

A commitment to pre-service teachers' growth in agency may pave the way for them to be more agentive throughout the rest of their career, while hand holding and encouraging their adherence to scripted curriculum or another teacher's curriculum may hold them back for the rest of their career.

I now turn to implications for districts and schools, who might assist in teachers' development of collaborative practice and interdependence on one another, to the ends that teachers gain agency, new knowledge is created, and students benefit from purposeful and innovative instruction.

\subsubsection{Implications for districts and schools}

Ellis and McNicholl (2015) delineate between what they call mode 1 knowledge production and mode 2 knowledge production. While mode 1 knowledge production is

"determined by academic interests that are primarily cognitive in nature" (p. 137), mode 2 
knowledge production is transdisciplinary, heterogeneous, socially accountable and reflexive in nature, arising out of the sorts of hybrid social practices for which Ellis and McNicholl (2015) advocate. They importantly note that these social practices out of which mode 2 knowledge arises are "at the same time academic and non-academic, instrumental and critical, personal and political," which rely on "distributed agency and trust between...partners" (p. 137). They emphasize repeatedly that these relationships of coconfiguration are more likely to support teachers, with the effect of greater agency and creativity in the education profession. It is possible that the collaborative had a great impact on teachers like Tami, Kellen, Walt, and Sydney because of its promotion of mode 2 knowledge production, rather than mode 1, as teachers worked together across schools, grades, and content areas, relying on distributed agency in hybrid spaces.

When I interviewed Gwen, she stressed the importance of school and district support for mode 2 knowledge production and hybrid spaces (without using those terms), emphasizing that these institutions must 1) cultivate trust for teachers, which leads them in turn to 2) allow innovative teachers to take the lead in schools, 3) offer teachers opportunities to "get outside of the field," and 4) encourage 'teacher meet-up.' I share Gwen's suggestions below.

\subsubsection{Develop trust for teachers}

Gwen believes that fostering district and school cultures in which teachers are trusted is essential to growth in teacher innovation. She acknowledged in the interview that this is difficult, because:

you have some teachers who will let kids have a discussion every day that doesn't go anywhere, or who will plop on a movie, or who will do meaningless activities that 
don't have at its [sic.] heart any actual reason for existing. So, from an admin perspective, they're fearful to let teachers...have that freedom, and then the negative impact of that is then you actually have high quality innovative teachers who feel like they don't actually have the permission that...they really do.

Gwen believes that in spite of the potential difficulties that may arise when teachers are given greater trust by the institutions for whom they work, "if you put systems in place that...have a trust for teachers...lots of things would happen as a result." One result of this trust could be teachers who are innovative having the opportunity to take on greater leadership at schools, and other teachers, seeing them, aspiring to follow their example. Gwen shared that she has seen glimmers of this process unfold, but for the most part, this is not the way in which districts and schools function. Below, I detail Gwen's thoughts regarding who usually takes charge in a school, what happens when innovative teachers become leaders, and the obstacles that must be addressed when seeking to give innovative teachers more leadership opportunities.

\subsubsection{Put innovative teachers in positions of leadership}

Gwen shared that more often than not, it is not innovative teachers who think outside the box who tend to become department chairs and PLC leaders, but the teachers who are "good at following instruction and the ones who are good at doing what they're told." She believes that this tendency of schools may serve to reinforce, rather than challenge, teachers' following of scripted curriculum.

Although the eight teachers involved during the first year of the collaborative did not begin as department chairs or PLC leaders, Gwen noted that "small miracles" occurred with regard to their influence on other teachers. These teachers, having been given time and space to innovate and to collaborate, began to influence the perspectives of other teachers, not 
necessarily by their words, but by the impact that they were having on students. "[B]ecause they were trying new things, the kids would go and they would talk about it in the other classes, and even the naysayers would come and ask those eight teachers for advice," Gwen said. “[T] heir pride wouldn't let them come and ask me necessarily, but they would go and talk to these eight teachers, and they would say, 'Hey, the kids are talking about this thing you did. Can you tell me about it?"”

Gwen specifically shared about the influence of Walt on his department chair, who was an eighteen-year teaching veteran, was skeptical of Gwen and the collaborative, and tended toward using the scripted curriculum. However, this department chair trusted Walt, and gradually began spending more time around Walt's classroom after school to see what he was doing, because students were talking about it. Gradually, he began to ask Walt questions like, "Hey, how'd you do that thing?” or "Can I see your materials?” or "Hey, I have this idea. What do you think?” Gwen noted, “And then Walt was taking the strategies I was using to coach him to coach that teacher into being more innovative." Gwen acknowledge that a teacher like this would not become 'Mr. Innovation' overnight, but she concluded, "[] $\mathrm{f}$ you have leaders in the building who are innovating and doing that kind of work, and they are trusted and valued by the rest of the staff, eventually other teachers will get on board, because they don't want to be left out."

Gwen was careful to share that administrators must beware of trying to mandate innovation, acknowledging that even the principal at Applewood who gave her the freedom to begin the collaborative had an attitude that said, "[Y]ou've got eight teachers who are doing this awesome stuff, but I need ninety-five doing it." She tried to convince him that, although it is frustrating, "you can't snap your fingers and every teacher in the building's going to be an innovator. It's just not the way it works." Innovation, beginning with the 
teachers who are desirous of it, organically and over time, is far more likely to infiltrate our schools than innovation that just becomes another institutional mandate. This is what occurred at Applewood; beginning with innovation in the classrooms of teachers like Tami, Sydney, and Walt, other teachers began to notice the positive impact of their work on students, and to follow their lead.

\subsubsection{Encourage teachers to 'get outside of the profession'}

Another of Gwen's suggestions was that teachers and school leaders should be encouraged by their district and school to "get outside of the profession." Gwen noted that one of the weaknesses she sees in the profession is that most district and school leaders started teaching at twenty-two, and do not have experience outside of the field of education. "[T] he system is incredibly incestuous, you know?...of course we want educators leading the profession. I'm not saying that [we don't want that]. But I do think there is something to say for educators stepping outside of...the norm of what they think is valuable professional learning."

Apart from Gwen's work as an entrepreneur informing her design of the collaborative, her experience outside of the teaching profession, working as a writer for The Atlantic also inspired her approach to teaching English. She shared how the feedback that she received on her pieces for The Atlantic often asked her to do in her writing the opposite of what she was telling her students at the time to do. She learned invaluable lessons, and it shaped the way that she viewed education and the way she communicated with her students. "And how many biology teachers in the world right now have never actually worked in a biology lab?” she questioned. "And so, we end up like, shooting ourselves in the foot in 
many ways, because we only build leaders from within, we only get ideas from within, and that...stifles innovation."

When I asked Gwen what she suggested schools might do in order to encourage teachers to "get outside of the profession," she mentioned countries around the world that offer sabbaticals and schools in another state in the U.S. where teachers receive professional development credit from working in industry over the summer, calling this a "teacher externship." She continued by mentioning the collaborative, saying that part of its mission was to encourage teachers to "[bring] the outside world in." She said that many of the teachers, as a part of their innovative designs, brought in speakers and formed partnerships with people in the community. Encouraging teachers to go outside of the profession and to bring the outside world into the classroom, like many of the ideas mentioned above, encourages collaborative partnerships, new knowledge, and teacher agency.

\subsubsection{Support 'teacher meet-up'}

Another of Gwen's suggestions, and the one that she was perhaps most passionate to talk about, was the encouragement of 'teacher meet-up.' She emphasized repeatedly that "in order for people to take risks, they have to be vulnerable," and they have to feel safe being vulnerable.

"I always joke that if I were getting a $\mathrm{PhD}$, my dissertation would be on teacher happy hour," she said. "Because although formally, I created this program and it was a thing, in every school I've been in, there was a happy hour group, right?” She shared that during the meetings of which she was a part in previous schools and during the meetings in pubs or cafés that took place during the collaborative, teachers would come and say things like, "Oh 
my gosh...I did this whole thing and it blew up in my face and it was a big disaster and I'm really frustrated and I have no idea what to do." They felt free to voice their failures and concerns. She continued:

But they couldn't go to their PLC meeting and do that, because it was way too buttoned-up and they felt judged. And they felt incompetent. And they felt like, 'Well, what's wrong with me? If this is working for everybody else, why isn't it working for me?' And that stifles innovation at its start, because... if you don't feel safe, and you can't be vulnerable, then you cannot take a risk. And you have to be able to take risks to innovate.

The power of teachers meeting in a different environment, from Gwen's perspective, is great. When I asked Gwen what she would encourage districts and schools to do in order to encourage this, she said, “[F]rom a district standpoint...I would encourage it and stay out of the way....encourage teacher meet-up....but then let it happen.” She noted more than once the importance of administration "staying out of the way." She shared that during the second year of the collaborative, some principals came to cohorts' meetings. "I don't necessarily know that that was a good idea," she said. Regardless of whether the principals had good relationships with the teachers, she felt that their presence changed the dynamics, affecting teachers' ability to be vulnerable.

"Fear and control and safety are the root of all of it," Gwen said of teachers' lack of innovation. "All of it." She believes that it is crucial for districts and schools to prioritize trust for teachers, to encourage teachers to bring new ideas and experiences into the profession, and to create opportunities for teachers to form relationships with one another that welcome innovation and vulnerability.

Fostering teacher innovation in districts and schools requires vulnerability not only on the part of school administrators and teachers, but from district leaders. I interviewed Gwen in the middle of the summer, before another school year had begun, and she shared with me that the collaborative was no longer going to be supported by the district. While 
there were several district leaders who were excited about the program, the district "kept giving [her] the run-around forever," she said. "In the end, I kind of realized that it really came down to the fact that...nobody wanted to make an actual decision [about supporting the collaborative for another year], because nobody actually had any power to do so." She mentioned that in the process of waiting on the district approval, she spoke about it to a friend who had previously worked for the district. "Yeah, that's the thing about WCPS," he had said. "Nobody wants to make an actual decision, because it's so political." Speaking on behalf of those who would potentially support the program, Gwen noted, "So... if you put your neck out there and you say, 'Okay, this is a program that's valuable. We're going to put money behind it. We're going to do this,' and then it doesn't work out, then you've put your neck on the line... and people just aren't willing to do that, you know?" Gwen believes that it takes "courageous steps from within the system" in order for initiatives like the collaborative to continue.

\subsubsection{Implications for teachers}

Simply taken from the implications above, it can be suggested that teachers devote themselves to developing informal, collaborative relationships (with people from within and outside of the field) in which they can be vulnerable, pursue opportunities to "get outside of the profession," seek mentorship, and take time to reflect on their motivations for teaching and how they approach their instruction.

Taylor (2019) adds that "teachers can-both independently and in collaboration with others-analyze how they are positioning themselves relative to the constraints placed upon their practice and interrogate the rights and duties afforded by that positioning." While this 
subject can be taken up by teacher educators, which Taylor encourages, it can also be taken up by districts, schools, groups of teachers, and individuals. In analyzing how they position themselves in their narratives about their teaching lives, "teachers can develop their abilities to locate spaces of agentic possibility, deliberately engaging with the current system while working towards more just instantiations" (Taylor, 2019, p. 214). Doing this takes courage.

Gwen acknowledged several times that the pursuit of innovation is much scarier than many assume, sharing that even the most devoted innovators with whom she worked at Applewood had moments when, in the midst of their innovation, things seemed to fall apart. They felt like they'd lost control. Even teachers like Kellen, she said, had to be coached through difficult moments when they felt as though various administrators, other teachers or even students were at odds with what they were trying to do, or were trying to strike the balance of how much structure and freedom were beneficial to classroom learning. Gwen noted that if these inner conflicts arose even for teachers who were willingly pursuing innovation, how much more so they would be daunting to those who have been "getting their curriculum in the mail for a decade." Issues of behavior come about in the midst of giving more control to students, required assessments bring stress when one is purposely striving not to 'teach to the test,' and staying on track with one's colleagues can cause intense feelings of pressure. Yet, innovation is worth pursuing in spite of these difficulties. "Beautiful pedagogy...has a rhythm," Gwen said. "It's in response to what's happening in front of you." The vulnerability that it takes to pursue innovative teaching is worth it for students' sakes, because it responds to them as people and learners. And, suggested Gwen, it may be less daunting than what many teachers believe it to be. She shared her own story of development as a teacher to illustrate this point:

I was at four different schools over fourteen years. So, when you start fresh at a brand-new school, there's always that, like, 'Okay, let me figure out what the rules 
are here. Let me figure out what the game is.' But at the end of the day, you go in your classroom, you shut the door, it's your classroom, you know? That's what I kind of realized eventually is... there are no curriculum police. No one's gonna come bang on my door and tell me, 'Oh... you're out of your mind.' What I kind of realized over having all those different principals, being in all those different settings, working with all those different people, is that if I knew my reason for doing what I was doing, and I had the intelligence and the intellectual chops to back up, 'Oh, I made this decision as a lesson design decision or curriculum design decision or whatever it might be, because of x, y, and z,' and I can explain it, I found that, without fail, a hundred percent, across the board, people leave me alone...You know, I mean that's happened to me in every school I've been in. I come up with crazy ideas, I have good relationships with my principals, my principals trust me, when I want to do something kind of out-of-the-box, I explain why I want to do it, and I usually get permission to do it.

"There are no curriculum police." Teachers may come up against various difficulties in their pursuit of structurally transformative agency, but if they are able to justify their instructional design based on their students' best interests, they will often be able to overcome these challenges. In this section, I have shown that hybrid spaces, relationships of coconfiguration, a focus on mode 2 knowledge production, trustful administrators, leadership opportunities for innovative teachers, encouragement of teachers to experience work outside of the profession of education, teacher meet-up, mentorship, reflective practice, and intentional conversations about agency can assist teachers on the journey toward structurally transformative agency.

\subsection{IMPLICATIONS FOR FUTURE RESEARCH}

In addition to the implications suggested above for teacher preparation programs,

districts, schools, and teachers, I offer direction for future research, some of which I plan to follow, myself, as this study provided far more data than I was able to report here and many possibilities for exploration. 
First, I intend to return to the data that were collected during this study in order to analyze it using the tools of discourse analysis. I believe that in focusing more intently on the make-up of teachers' discourse patterns, far more meaning could be mined in order to better understand the inner workings of teacher agency and the influences that play on it. I also plan to return to these data in order to theorize a spectrum for teacher agency that might add nuance to the understandings of structurally transformative agency, structurally reproductive agency, and non-agency, as teachers' agentive practices are far more complex than what can fit into three simplified categories. I feel as though I have scratched the surface of this complexity, but hope to dive more deeply into it in the future. Additionally, I plan to elaborate on some of the most important figures in this dissertation, which suggest trajectories for future research that could bolster my argument in this section and build on the findings that I have already uncovered.

Regarding other future research, I believe that it would be helpful to conduct a study that asks similar research questions, but relies on direct observation of teachers' practices in addition to their perceptions. I also believe that it is imperative to continue to look into the hierarchical structures, beginning with the state, filtering down through higher education, and into K-12 schools that hinder teachers' development of agency, and also to look at initiatives that seem to support teachers' growth in agency. Studying more 'hybrid spaces,' professional collaboratives, or 'teacher meet-ups' in which teachers are purposefully cultivating innovative practices could be very enlightening to the discussion at hand. 


\subsection{CONCLUSION}

In this study, I explored the curricular conceptions and practices of Tami, Kellen, Walt, Robert, Sydney, Hannah, and Michelle-seven diverse teachers who took part in the innovative professional collaborative-as well as the influences on their agency. I was privileged to have the opportunity to carry out this study during the second and final year of the collaborative, which, like many initiatives designed for the growth of teacher agency and innovation, was quenched because of difficult political dynamics in the district, which answers to the state for its designation of funding and other resources. In spite of this discouraging ending to the collaborative, I believe that it displays well the systemic weaknesses that Ellis and McNicholl (2015), Furlong (2014), and Gutmann (1999) point out. In order to combat the expectations of districts, schools, and teachers "of being continually guided by the state to the detriment of their human agency and creativity" (Furlong, 2014, p. 125), we must consider the types of influences and contact zones that help to foster teachers' structurally transformative agency in the midst of trying circumstances. This study offers some helpful avenues for continuing to pursue this end. 


\section{REFERENCES}

Allen, Q. (2015). Race, culture and agency: Examining the ideologies and practices of U.S. teachers of black male students. Teaching and Teacher Education, 47(1), 71-81.

Apple, M. (2009). Controlling the work of teachers. In S. J. Thornton \& D. J. Flinders (Eds.), The Curriculum Studies Reader (3rd ed., pp. 199-213). New York, NY: Routledge.

Archer, M. (2000). Being buman: The problem of agency. Cambridge, UK: Cambridge University Press.

Atkinson, R. (2012). The life story interview as a mutually equitable relationship. In J.F. Gubrium, J.A. Holstein, A. B. Marvasti, \& K. D. McKinney (Eds.). The SAGE bandbook of interview research (2nd ed., pp. 115-128). Los Angeles: SAGE Publications, Inc.

Baker-Doyle, K. and Gustavson, L. (2016). Permission-seeking as an agentive tool for ' transgressive teaching: An ethnographic study of teachers organizing for curricular change. Journal of Educational Change, 17(1), 51-84.

Bakhtin, M. (1981). Discourse in the novel. In M. Bakhtin (Ed.), The dialogic imagination: Four essays (M. Holquist, Ed.; C. Emerson \& M. Holquist, Trans.; pp. 259-422). Austin, TX: University of Texas Press.

Ball, D., \& Cohen, D. (1999). Developing practice, developing practitioners: Toward a practice-based theory of professional education. In L. Darling-Hammond \& G. Sykes (Eds.), Teaching as the learning profession (pp. 3-32). San Francisco, CA: JosseyBass

Bender-Slack, D. (2010). Texts, talk... and fear? English language arts teachers negotiate social justice teaching. English Education, 42(2), 181-203.

Ben-Peretz, M., Mendelson, N., \& Kron, F. W. (2003). How teachers in different educational contexts view their roles. Teaching and Teacher Education, 19, 277-290.

Bieler, D. (2013). Strengthening new teacher agency through holistic mentoring. The English Journal, 102(3), 23-32.

Bieler, D., Holmes, S. and Wolfe, E.W. (2017). Patterns in the initial teaching assignments of 
secondary English teachers: Implications for teacher agency and retention. The New Educator, 13(1), 22-40.

Biesta, G. (2004). Education, accountability, and the ethical demand: Can the democratic potential of accountability be regained? Educational Theory, 54, 233-250.

Biesta, G., Priestley, M., \& Robinson, S. (2015). The role of beliefs in teacher agency. Teachers and Teaching, 21, 624-640.

Biesta, G., \& Tedder, M. (2007). Agency and learning in the lifecourse: Towards an ecological perspective. Studies in the Education of Adults, 39(2), 132-149.

Bogdan, R. C., \& Biklen, S. K. (1992). Qualitative research for education: An introduction to theory and methods. Boston, MA: Allyn and Bacon.

Borko, H. (2004). Professional development and teacher learning: Mapping the terrain. Educational Researcher, 33(8).

British Educational Research Association (2014). Building the capacity for a self- improving education system. Research and the teaching profession. Final report of the BERA-RSA Inquiry into the role of research in teacher education. Retrieved from London, UK: https://www.bera.ac.uk/wp-content/uploads/2013/12/BERA- RSA-ResearchTeaching-Profession-FULL-REPORT-for-web.pdf.

Buchanan, R. (2015). Teacher identity and agency in an era of accountability. Teachers and Teaching, $21(6), 700-719$.

Campbell, E. (2012). Teacher agency in curriculum contexts. Curriculum Inquiry, 42(2), 183 190.

Carver, C. L. (2004). A lifeline for new teachers. Educational Leadership, 61(8), 58-61.

Catling, S. (2013). Teachers' perspectives on curriculum making in primary Geography in England. Curriculum Journal, 24(3), 427-453.

Chisholm, J., Alford, J., Halliday, L., \& Cox, F. (2019). Teacher agency in English language arts teaching: A scoping review of the literature. English Teaching: Practice \& Critique, 18(2), 124-152.

Clandinin, D. J., \& Connelly, F. M. (1992). Teacher as curriculum maker. In P. Jackson (Ed.), Handbook of curriculum (pp. 363-461). New York, NY: Macmillan.

Clayton, C. (2007). Curriculum making as novice professional development: Practical risk taking as learning in high-stakes times. Journal of Teacher Education, 58(3), 216-230.

Cole, A. L., \& Knowles, J. G. (2001). Lives in context: The art of life history research. Walnut Creek: Altamira Press. 
Cox, S. (2011). New perspectives in primary education. Maidenhead, UK: Open University Press.

Craig, C. J. (2010). Teachers as curriculum makers. In C. Kridel (Ed.), Encyclopedia of curriculum studies (pp. 867-869). Thousand Oaks, CA: Sage.

Darling-Hammond, L., \& Bransford, J. (Eds.) (2005). Preparing teachers for a changing world: What teachers should learn and be able to do. San Francisco, CA: Jossey-Bass.

Day, C. (2018). Professional identity matters: Agency, emotions, and resilience. In P. A. Schutz, J. Hong, \& D. C. Francis (Eds.), Research on teacher identity: Mapping challenges and innovations (pp. 61-70). Springer International Publishing.

Dewey, J. (1902). The child and the curriculum. Chicago: University of Chicago Press.

Dewey, J. (2009). My pedagogic creed. In S. J. Thornton \& D. J. Flinders (Eds.), The Curriculum Studies Reader (3rd ed., pp. 34-41). New York: Routledge.

Dierking, R. C. and Fox, R. F. (2013). 'Changing the way I teach': Building teacher knowledge, confidence, and autonomy. Journal of Teacher Education, 64(2), 129-144.

Dyson, A., Genishi, C. (2005). On the case: Approaches to language and literacy research. New York, NY: Teachers College Press/NCRLL.

Early, J., \& Shagoury, R. (2009). Learning from the lived experiences of new language arts teachers working in diverse urban schools. Teaching and Teacher Education, 26(4), 10491058.

Eisner, E. (2009). What does it mean to say a school is doing well? In S. J. Thornton \& D. J. Flinders (Eds.), The Curriculum Studies Reader (3rd ed., pp. 327-335). New York: Routledge.

Ellis, V. (2013). Professional creativity: Towards a collaborative community of teaching. In A. Sannino \& V. Ellis (Eds.), Learning and Collective Creativity: Activity-Theoretical and Sociocultural Studies (pp. 216-233). London \& New York, NY: Routledge.

Ellis, V. \& McNicholl, J. (2015). Public universities and the profession of teaching: Towards an agenda of transformation. In V. Ellis \& J. McNicholl (Eds.), Transforming Teacher Education: Reconfiguring the Academic Work (pp. 123-152). London: Bloomsbury.

Emerson, R.M., Fretz, R. I., \& Shaw, L. L. (2011). Writing ethnographic fieldnotes. Chicago, IL: University of Chicago Press.

Emirbayer, M., \& Mische, A. (1998). What is agency? American Journal of Sociology, 103(4), 962-1023.

Eteläpelto, A., Vähäsantanen, K., Hökkä, P., \& Paloniemi, S. (2013). What is agency? 
Conceptualizing professional agency at work. Educational Research Review, 10, 45-65.

Fine, M. (1994). Working the hyphens: Reinventing self and other in qualitative research. In N. K. Denzin \& Y. S. Lincoln (Eds.), Handbook of qualitative research. (pp. 70-82). London, UK: Sage Publications.

Flores, M. A., \& Day, C. (2006). Contexts which shape and reshape new teachers' identities: a multi-perspective study. Teaching and Teacher Education, 22(2), 219-232.

Foley, R. M., \& Pang, L. S. (2006). Alternative education programs: Program and student characteristics. The High School Journal, 89, 10-21.

Freedman, S. W. \& Ball, A. F. (2004). Ideological becoming. Bakhtinian concepts to guide the study of language, literacy, and learning. In A.F. Ball and S.W. Freedman (Eds.), Bakbtinian Perspectives on Language, Literacy, and Learning (pp. 3-33). Cambridge: Cambridge University Press.

Freire, P. (1998). Teachers as cultural workers: Letters to those who dare teach (The edge, critical studies in educational theory). Boulder, CO: Westview Press.

Furlong, J. (2014). The discipline of education: Rescuing the 'university project'. In Learning to Teach. Part 1: Exploring the History and Role of Higher Education in Teacher Education (pp. 5-9). New York, NY: Higher Education Academy.

Furlong, J. (2015). Teaching tomorrow's teachers: Options for the future of initial teacher education in $W$ ales. Oxford, UK: University of Oxford.

Glaser, B. G. and Strauss, A. L. (1967). The discovery of grounded theory. Chicago, IL: Aldine.

Golden, N. (2018). Narrating neoliberalism: Alternative education teachers' conceptions of their changing roles. Teaching Education, 29(1), 1-16.

Golden, N., \& Womack, E. (2016). Literacy and relationships with adolescent scholars of color. English Journal, 105, 36-42.

González, N., Moll, L. C., \& Amanti, C. (Eds.) (2013). Funds of knowledge: Theorizing practices in households, communities, and classrooms. New York, NY: Routledge.

Grossman, P. L., Thompson, C., \& Valencia, S. W. (2002). Focusing the concerns of new teachers: the district as teacher educator. In M. Knapp, M. McLaughlin, J. Marsh, \& A. Hightower (Eds.), School districts and instructional renewal: Opening the conversation (pp. 129-142). New York: Teachers College Press.

Gudmundsdottir, S. (1991). Story-maker, story-teller: Narrative structures in curriculum. Journal of Curriculum Studies, 23(3), 207-218.

Gutmann, A. (1999). Democratic Education. Princeton, NJ: Princeton University. 
Harste, J. C., \& Short, K. G. (2010). Creating curriculum. In P. L. Anders (Ed.), Defying convention, inventing the future in literacy research and practice: Essays in tribute to Ken and Yetta Goodman (pp. 126-135). New York, NY: Taylor \& Frances.

Hays, S. (1994). Structure and agency and the sticky problem of culture. Sociological Theory, 12(1), 57-72.

Hökkä, P., \& Vähäsantanen, K. (2013). Agency-centred coupling-a better way to manage an educational organization? International Journal of Leadership in Education, 17(2), 131153. http:/ / dx.doi.org/10.1080/13603124.2013.783932.

Hökkä, P., Vähäsantanen, K., \& Mahlakaarto, S. (2015). Teacher educators' collective agency and identity re-negotiation amid tensioned work practices. In D. Garbett \& A. Ovens (Eds.), Teaching for tomorrow today (pp. 78-87). Auckland: Edify Ltd.

Johnson, S. M., \& Birkland, S. E. (2003). The schools that teachers choose. Educational Leadership, 60(8), 20-24.

Johnson, S. M., Birkland, S. E., Kardos, S. M., Kauffman, D., Liu, E., \& Peske, H. G. (2001 July/August). Retaining the next generation of teachers: the importance of schoolbased support. Harvard Education Letter.

Kelly, A. (2009). The curriculum: Theory and practice (6th ed.). London: Sage.

Knapp, M. S., \& McLaughlin, M. W. (1999). The district role in the renewal of teaching: Framing the conversation and the research. Paper presented at the annual meeting of the American Educational Research Association, Montreal, Canada.

Kolman, J. S., Roegman, R., \& Goodwin, A. L. (2016). Context as mediator: Teaching residents' opportunity and learning in high-need urban schools. Teaching Education, 27, 173-193.

Kontovourski, S., Philippous, S. \& Theodorou, E. (2018). Curriculum making as professionalism-in-context: The cases of two elementary school teachers amidst curriculum change in Cyprus. The Curriculum Journal, 29(2), 257-276.

Lopez, A. E. (2011). Culturally relevant pedagogy and critical literacy in diverse English classrooms: A case study of a secondary English teacher's activism and agency. English Teaching: Practice and Critique, 10(4), 75-93.

Martinie, S. L., Kim, J. H. \& Abernathy, D. (2016). "Better to be a pessimist": A narrative inquiry into mathematics teachers' experience of the transition to the common core. Journal of Educational Research, 109, 658-665.

Merriam, S. B. (2007). Qualitative research and case study applications in education (2nd ed.) San Francisco, CA: Jossey-Bass. 
Meyer, H. D., \& Rowan, B. (2006). The new institutionalism in education. Albany, NY: SUNY Albany Press.

Miles, M. B. \& Huberman, A. M. (1994). Qualitative data analysis (2nd ed.). Thousand Oaks, CA: Sage publications.

Miller, E. R., Morgan, B. and Medina, A. L. (2017). Exploring language teacher identity work as ethical self-formation. The Modern Language Journal, 101 (S1), 91-105.

Nguyen, H. T. M., \& Bui, T. (2016). Teachers' agency and the enactment of educational reform in Vietnam. Current Issues in Language Planning, 17, 88-105.

Oolbekkink-Marchand, H. W., Hadar, L. L., Smith, K., Helleve, I., \& Ulvik, M. (2017). Teachers' perceived professional space and their agency. Teaching and Teacher Education, 62(2017), 37-46.

Patton, M. Q. (1990). Qualitative educative methods (2nd ed.) Thousand Oaks, CA: Sage.

Pease-Alvarez, L. and Samway, K. D. (2008). Negotiating a top-down reading program mandate: The experiences of one school. Language Arts, 86(1), 32-41.

Priestley, M., Biesta, G. J. J., Philippou, S., \& Robinson, S. (2016). The teacher and the curriculum: Exploring teacher agency. In D. Wyse, L. Hayward \& J. Pandya (Eds.), The SAGE Handbook of Curriculum, Pedagogy and Assessment (pp. 1-30). London, UK: SAGE Publications Ltd.

Priestley, M., Biesta, G. J. J ,\& Robinson, S. (2013). Teachers as agents of change: teacher agency and emerging models of curriculum. In: M. Priestley \&G.J.J. Biesta (Eds.), Reinventing the Curriculum: New Trends in Curriculum Policy and Practice (pp. 187- 206). London, UK: Bloomsbury Academic.

Priestley, M., Biesta, G. J. J., \& Robinson, S. (2015). Teacher agency: An ecological approach. London, UK: Bloomsbury Academic.

Priestley M., Edwards, R., \& Priestley, A., \& Miller, K. (2012): Teacher agency in curriculum making: Agents of change and spaces for manoeuvre. Curriculum Inquiry, 42(2), 192 214.

Priestley, M., Minty, S., \& Eager, M. (2014). School-based curriculum development in Scotland: Curriculum policy and enactment. Pedagogy, Culture \& Society, 22, 189-211.

Pyhältö, K., Pietarinen, J., \& Soini, T. (2014). Comprehensive school teachers' professional agency in large-scale educational change. Journal of Educational Change, 15, 303-325.

Putnam, R. \& Borko, H. (1997). Teacher learning: Implications of new views of cognition. In B. J. Biddle, T.L. Good, \& I.F. Goodson (Eds.), The International Handbook of 
Teachers and Teaching (pp. 1223-1296). Dordrecht, The Netherlands: Kluwer.

Puzio, K., Newcomer, S., Pratt, K., McNeely, K., Jacobs, M., \& Hooker, S. (2017). Creative failures in culturally sustaining pedagogy. Language Arts, 94(4), 223-233.

Rivera Maulucci, M. S., Brotman, J. S, \& Sprague Fain, S. (2015). Fostering structurally transformative teacher agency through science professional development. Journal of Research in Science Teaching, 52(4), 545-559.

Rubin, J. C. and Land, C. L. (2017). 'This is English class': Evolving identities and a literacy teacher's shifts in practice across figured worlds. Teaching and Teacher Education, 68(1), 190-199.

Salzman, P. C. (2002). On reflexivity. American Anthropologist, 104(3), 805-813.

Schmidt, R., \& Whitmore, K. F. (2010). Analyzing the language of struggle in search of hope for teachers, Journal of Literacy Research, 42(4), 1-33.

Schwab, J. (1969). The practical: A language for curriculum. School Review, 28, 1-24.

Shagoury, R., Campbell, K., \& Carreker, S. (2007). Conversations with beginning teachers: a research-based model of support. In: Choice Literacy. Retrieved 02.12.19. from www.choiceliteracy.com.

Shawer, S. (2010). Classroom-level curriculum development: EFL teachers as curriculumdevelopers, curriculum-makers and curriculum-transmitters. Teaching and Teacher Education, 26 (2010), 173-184.

Shawer, S. (2017). Teacher-driven curriculum development at the classroom level: Implications for curriculum, pedagogy and teacher training. Teaching and Teacher Education, 63, 296-313.

Simpson, A., Sang, G., Wood, J., Wang, Y., \& Ye, B. (2018). A dialogue about teacher agency: Australian and Chinese perspectives. Teaching and Teacher Education, 75(2018), 316-326.

Smagorinsky, P., Wilson, A.A. and Moore, C. (2011). Teaching grammar and writing: A beginning teacher's dilemma. English Education, 43(3), 262-292.

Spring, J. (2015). Economization of education: Human capital, global corporations, skills-based schooling. New York, NY: Routledge.

Stagg-Peterson, S. (2012). An analysis of discourses of writing and writing instruction in curricula across Canada. Curriculum Inquiry, 42(2), 260-284.

Stake, R. (2006). Multiple case study analysis. New York, NY: Guilford Press. 
Starkey, L. (2010). Supporting the digitally able beginning teacher. Teaching and Teacher Education, 26(7), 1429-1438.

Talbert, J., McLaughlin, M., \& Rowen, B. (1993). Understanding context effects on secondary school teaching. Teachers College Record, 95, 45-68.

Tao, J. and Gao, X., (2017). Teacher agency and identity commitment in curricular reform. Teaching and Teacher Education, 63(1), 346-355.

Tarnoczi, J. (2006). Critical reflections of professional learning communities in Alberta. Electronic Journal of Sociology. Retrieved from http://sociology.org/content/2006/tier2/tarnoczi.html

Taylor, L. (2019). Rights, duties, and spaces of agency amidst high-stakes testing. English Teaching: Practice \& Critique, 18(2), pp. 204-217.

Ticknor, A.S. (2015). Critical considerations in becoming literacy educators: Pre-service teachers rehearsing agency and negotiating risk. Teaching Education, 26, 383-399.

Timberlake, M., Burns, A., \& Barrett, B. (2017). The allure of simplicity: Scripted curricula and equity. Teaching and Teacher Education, 67(2017), 46-52.

Valsiner, J. \& van der Veer, R. (2000). The Social Mind: Construction of the Idea. Cambridge: Cambridge University Press.

Vaughn, M. and Faircloth, B. S. (2011). Understanding teacher visioning and agency during literacy instruction. In P. L. Dunston, L. B. Gambrell, K. Headley, S. K. Fullerton, P. M. Stecker, V. R. Gilles, \& C. C. Bates (Eds.), 60th Yearbook of the Literacy Research Association (pp. 156-164). Oak Creek, WI: Literacy Research Association.

Voogt, J., Westbroek, H., Handelzalts, A., Walraven, A., McKenney, S., Pieters, J., \& de Vries, B. (2011). Teacher learning in collaborative curriculum design. Teaching and Teacher Education, 27(2011), 1235-1244.

Wang, Y., Mu, G. M. and Zhang, L. (2017). Chinese inclusive education teachers' agency within temporal-relational contexts. Teaching and Teacher Education, 61(1), 115-123.

Weiss, E. M. (1999). Perceived workplace conditions and first-year teachers' morale, career choice commitment, and planned retention: a secondary analysis. Teaching and Teacher Education, 15(8), 861-887.

Wessel-Powell, C., Buchholz, B., \& Brownell, C. (2019) Polic(y)ing time and curriculum: How teachers critically negotiate restrictive policies. English Teaching: Practice \& Critique, 18(2), 170-187.

Williams, W. R. (2018). Attempting arts integration: secondary teachers' experiences with spoken word poetry. Pedagogies: An International Journal, 13(2), 92-105. 
Yin, R. (1994). Case study research: Design and methods (2nd ed.). Thousand Oaks, CA: Sage.

Zeichner, K., Payne, K., \& Brayko, K. (2012). Democratising knowledge in university teacher education through practice-based methods teaching and mediated field experiences in schools and communities. Issue Paper, 12(1). Seattle: University of Washington Center for the Study of Learning to Teach in Practice. 


\section{APPENDIX A}

\section{TEACHER BACKGROUND SURVEY}

The purpose of this survey is to identify a diverse set of 5-7 participants who have a broad range of teaching experience, have taught in various grades, subjects, and schools, and who come from a variety of educational backgrounds.

Please respond to each of the following questions:

1) Tell me about yourself. What do you like to do in your free time?

2) Tell me about your teaching career. How long have you taught? What subject(s) have you taught? Where have you taught? What grade levels?

3) Where did you pursue your teacher education? What can you tell me about your program?

4) What vision or goals for your instruction and students guide how and what you teach?

5) What particular teaching methods do you practice when you teach and why?

6) How would you describe your curriculum for the class on which you're focusing for the collaborative?

7) How do you see your innovative curriculum design(s) from this school year aligning with your beliefs, values, and convictions regarding teaching and learning? 


\section{APPENDIX B}

\section{TEACHER INTERVIEW PROTOCOL}

Building upon answers given in the initial survey, these individual interview questions aim particularly to answer research question 1: to discover teachers' conceptions of curriculum, their roles in curriculum, and what they believe to have influenced these conceptions and roles. Questions elicit teachers' perspectives regarding the iterational, practical-evaluative, and projective dimensions of their lives and experiences (Priestley et al., 2013).

1) What does the term "curriculum" call to mind when you hear it? Do you think that the idea that comes to mind is consistent with what you believe about curriculum? Why or why not?

2) Build off of Survey Questions 4, 5, and 6 to gain better insight into the teacher participant's beliefs about their role in curriculum:

a. What vision or goals for your students guide how and what you teach?

b. What particular teaching methods do you practice when you teach and why?

c. How would you describe your curriculum for the class on which you're focusing for the collaborative?

3) Have your views on what curriculum is or should be changed over time? If so, what do you think has catalyzed these changes? If not, what do you think has caused your views to stay the same?

4) Has the curriculum in your classroom changed during your months or years as a teacher? If so, why? Give me one or two examples of how it has changed. If not, what has kept it from changing? Do you think these influences are helpful?

5) Has your role in your classroom curriculum changed over time? If so, what influences have played a part in your shifting role? If not, why not?

6) Describe the type of relationships you have at your school with other teachers, administrators, and/or staff. 
7) What is considered to be effective teaching in this school?

8) The mission statement of your school says this (read mission statement). What do you think is the mission of teachers and administrators at this school?

9) How would you describe the physical environment of your school and classroom? To what kinds of resources do you have access?

10) How do you think being a part of this school impacts the way that your curriculum is carried out?

11) Tell me about your teacher education program. What did you feel prepared to do when you graduated? Is this preparation consistent with what you believe teachers should be prepared to do?

12) Tell me about how you as a person-your experiences, skills, or other attributescome through in your curriculum or are important to it. 


\section{APPENDIX C}

\section{VIDEO DIARY PROTOCOL}

The purpose of the video diaries is to further draw out teachers' thinking regarding their conceptualizations about and roles in curriculum, and how their participation in the collaborative has contributed to their thinking (Part I). To further understand the impact of the collaborative on teachers' beliefs and practices, they will be asked to provide an innovative instructional plan that they designed during their time in the collaborative. Referring to this instructional plan and their overall experience, participants will speak in response to the prompts provided in Part II.

\section{Part I}

1) Tell me about your experience in the collaborative this year. Looking back, did you gain what you expected to gain from it?

2) What has been the most surprising aspect about being a part of the collaborative?

3) Do you think your conceptualizations of curriculum and your role in curriculum have changed throughout the year? How?

4) Describe a moment from this year in which your previous ideas about curriculum, teaching, or learning were challenged. What happened as a result?

5) What do you hope to carry with you from this year into the year to come? How do you hope your classroom will look differently as a result of being a part of the collaborative?

Part II

6) Tell me about your innovative instructional plan or "build." What made you want to focus on this particular area during your time in the collaborative?

7) How do you think your beliefs/philosophy about teaching and learning come through in the design of your plan? 
8) How did your design of this plan look the same as or different from your design of classroom instruction in the past?

9) What obstacles did you come up against in designing this plan? In enacting it? What helped you to navigate them?

10) How do you think your participation in the collaborative impacted the way that your plan was designed? Enacted? 


\section{APPENDIX D}

\section{INTERVIEW QUESTIONS FOR THE FACILITATOR OF THE COLLABORATIVE}

The purpose of interviewing the facilitator of the collaborative is to understand the vision, mission, and structure of the collaborative, and to understand her perspective regarding the evolution of teachers' perceptions of and roles in curriculum; the influences that shape teachers' conceptualizations and practices; and the witnessed impact of the collaborative, in particular, on teachers' agency.

1) Tell me about yourself. What do you like to do in your free time?

2) Tell me about your teaching career. How long did you teach? What subject(s) have you taught? Where have you taught? What grade levels?

3) Tell me about your career now. What does a typical day or week look like?

4) What inspired you to begin the collaborative? How would you describe the vision and mission of the collaborative?

5) How is the collaborative different from other professional development experiences? What do you think might cause it to be more impactful than other school sponsored professional development experiences or university teacher education experiences?

6) What is the structure of the collaborative? Who is involved, when does it begin and end, what does participation in it look like on a weekly, monthly, and yearly basis? What differences were there in the structure between the first year and the second year?

7) What, if anything, do you feel might be lost whenever leaders aren't a daily reality in their mentees' school? What do you think the cohort from the first year might have gleaned from the process, that perhaps the cohorts from this year did not?

8) How do you view curriculum, and a teacher's role in curriculum? Has this always been your perspective? 
9) What influences do you perceive to be the greatest on teachers' curriculum beliefs and practices (perceived professional spaces, past teaching experiences, teacher education programs, other experiences, skills, or attributes)?

10) Tell me about a teacher (or two) who has been a part of the collaborative. In what ways have you witnessed their conceptualizations about or relationship with curriculum change?

11) Are there certain characteristics, motivations, or experiences that make for a teacher whom you believe may benefit more from this program? What characteristics do you look for in a potential mentor?

12) What do you think are the most important ways in which we can support teachers as agents and curriculum makers in our schools?

13) What steps would other schools or districts have to take in order to make a program like this happen? What beliefs, values or convictions have to be present in school or district administration in order for a program like this to be promoted?

14) Tell me about what you feel you've learned as the facilitator of the collaborative.

15) What are some of your goals or hopes for the collaborative going forward? 


\title{
CURRICULUM VITAE
}

\author{
Alysse C. Jacobs \\ 506 US Highway 46, Great Meadows, NJ 07838 \\ (814) 746-8052•alycjacobs@gmail.com・alysse.jacobs@louisville.edu
}

\section{EDUCATION}

Doctor of Philosophy in Curriculum and Instruction, University of Louisville, Kentucky. December 2019.

CONCENTRATIONS: Languages, Literacies, Cultures, and Communities

Rank I in Secondary Education, University of Louisville, Kentucky. August 2016. CONCENTRATION: Teaching English as a Foreign Language (Endorsement)

Master of Arts in Teaching, Spalding University, Louisville, Kentucky. May 2015. CONCENTRATIONS: Spanish P-12, English 7-12

Bachelor of Arts in English and Foreign Language, West Virginia University, Eberly School of Arts and Sciences, Morgantown, WV. May 2011.

CONCENTRATIONS: Creative Writing and Spanish

\section{LANGUAGES}

English: native proficiency

Spanish: bilingual proficiency

German: limited working proficiency

\section{PROFESSIONAL EXPERIENCE}

\section{WORK}

Clinton Township Public Schools, Hunterdon County, New Jersey

Middle School Spanish Teacher, April 2019-Present

Franklin Township and Frelinghuysen Township Schools, Warren County, New Jersey

Elementary School Spanish Teacher, September 2018-March 2019

Jefferson County Public Schools, Louisville, Kentucky

High School Spanish Teacher, August 2015-August 2018

Spanish Department Chair, PRP High School, 2016-2017 
Christian Academy of Louisville, English Station, Louisville, Kentucky

High School Spanish Teacher, August 2013-August 2015

Sophomore Class Sponsor, August 2014-May 2015

Spanish Club Director, August 2014-May 2015

Denton Calvary Academy, Denton, Texas

Teacher's Aide, Tutor, Substitute Teacher, August 2012-May 2013

\section{ACADEMIC}

Ad Hoc Manuscript Review, English Teaching: Practice \& Critique, Fall 2019

Conference Presentation, Jacobs, A. (2019, November). Curriculum making and teacher agency: A direct relationship. Paper presented at the ACTFL Annual Convention and World Languages Expo, Washington, D.C.

Teaching Assistant, College of Education, University of Louisville, Summer 2018 Course: Sociolinguistics and ESL

Ad Hoc Manuscript Review, Linguistics and Education, Spring 2018

Conference Presentation, Chisholm, J. S., Whitmore, K. F., Baize, J., \& Jacobs, A. (2017, May). Documenting, researching, and understanding arts-based inquiry with the Visual Learning Assessment. Paper presented at the meeting of the International Congress of Qualitative Inquiry, Urbana-Champaign, IL.

Research Apprenticeship, College of Education, University of Louisville, Fall 2016-Spring 2017. Assisted Dr. James Chisholm in researching multimodal assessment in the classroom and in the literature.

Study Abroad, Universidad de Guanajuato, Mexico, January-June 2010

CHISPA Experience, West Virginia University, middle school Spanish language/culture teaching in immersion, September-October 2010

\section{CURRENT RESEARCH INTERESTS}

Teacher education

Teacher agency

Teacher innovation

World language pedagogy and instructional design

\section{PROFESSIONAL ORGANIZATIONS}

American Educational Research Association (AERA)

American Council on the Teaching of Foreign Language (ACTFL) 


\section{HONORS AND AWARDS}

University of Louisville

GPA 4.0

EUMC Educational Award, 2016

College of Education and Human Development Scholarship, 2019

College of Education and Human Development Scholarship, 2018

Spalding University

Summa Cum Laude, GPA 4.0

J. Jerome Fargen Award for Educational Excellence

West Virginia University

Summa Cum Laude, GPA 3.96

Phi Beta Kappa Member, Academic Honorary

Dean's List Every Semester

Academic Excellence Level 1 Scholarship, August 2007-May 2011

Erie Scottish Rite Scholarship, 2010-2011 academic year

Gillespie Scholarship, Gillespie Foundation, 2009-2010 academic year

Eleanor Tucker Donley Memorial Scholarship, WVU English department, 2010-

2011 academic year

Elsie and Ethel Jones Scholarship, WVU English department, 2009-2010 academic year

West Virginia University Honors College, August 2007-May 2011

\section{COMMUNITY SERVICE}

Metanoia Children's Home Trip, Co-led sixteen high school students to Nicaragua, repaired orphanage, served at feeding centers and clinics, one week in March 2015

San Diego Trip, Co-led fourteen college students and tutored refugee children of San Diego, California, one week in March 2013

Missio Dei CollegeLife Trip, Co-led ten college students and assisted in a first grade classroom in Kingsport, Tennessee, one week in March 2012

CAM International Trip, Taught English and took care of children at Didasko Orphanage in Támara, Honduras, one month in 2010

International House Organization (WVU), Built relationships with and planned/hosted events for international university students, August 2010-May 2011 